Prepared in cooperation with the Virginia Department of Environmental Quality

\title{
Rating Stability, and Frequency and Magnitude of Shifts, for Streamgages in Virginia Through Water Year 2013
}

Scientific Investigations Report 2017-5137 



\section{Rating Stability, and Frequency and Magnitude of Shifts, for Streamgages in Virginia Through Water Year 2013}

By Terence Messinger and Robert W. Burgholzer

Prepared in cooperation with the Virginia Department of Environmental Quality

Scientific Investigations Report 2017-5137 


\title{
U.S. Department of the Interior \\ RYAN K. ZINKE, Secretary
}

\author{
U.S. Geological Survey \\ James F. Reilly II, Director
}

U.S. Geological Survey, Reston, Virginia: 2018

For more information on the USGS - the Federal source for science about the Earth, its natural and living resources, natural hazards, and the environment-visit https://www.usgs.gov or call 1-888-ASK-USGS.

For an overview of USGS information products, including maps, imagery, and publications,

visit https://store.usgs.gov.

Any use of trade, firm, or product names is for descriptive purposes only and does not imply endorsement by the U.S. Government.

Although this information product, for the most part, is in the public domain, it also may contain copyrighted materials as noted in the text. Permission to reproduce copyrighted items must be secured from the copyright owner.

Suggested citation:

Messinger, T., and Burgholzer, R.W., 2018, Rating stability, and frequency and magnitude of shifts, for streamgages in Virginia through water year 2013: U.S. Geological Survey Scientific Investigations Report 2017-5137, 91 p., https:// doi.org/10.3133/sir20175137. 


\section{Acknowledgments}

Many individuals contributed to the successful development of this study and report. Danny Daniels of the U.S. Geological Survey (USGS) entered flow measurements into the database over a period exceeding 10 years, which made the analysis possible. Thomas Gibson of the Virginia Department of Environmental Quality and Dennis Adams, Jim Duda, Karl Dydak, Mike Eckenwiler, Amanda Groves, Donna Justus, Keith Lambert, Russ Lotspeich, and Carlos Rodriguez, all of USGS, participated in interviews regarding the history, and bed and control characteristics, of streamgages. Discussions with Julie Kiang, Robert Mason, and John Atkins, all of USGS, were helpful in developing the analytical approach for this project. This report was improved by technical reviews by Russ Lotspeich and Robert Mason. 


\section{Contents}

Acknowledgments ........................................................................................................................

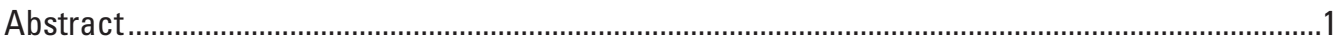

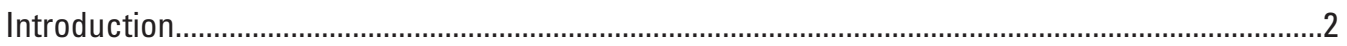

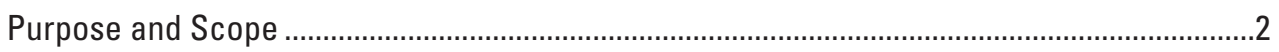

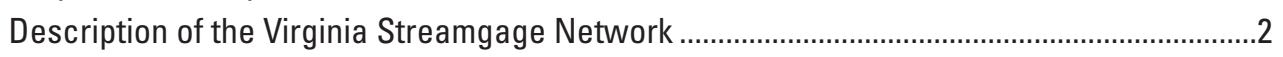

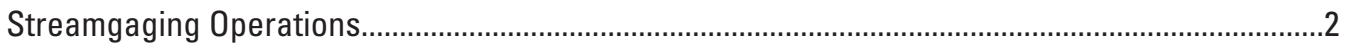

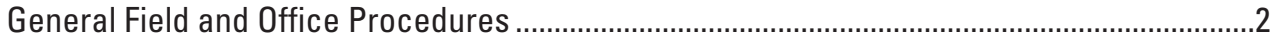

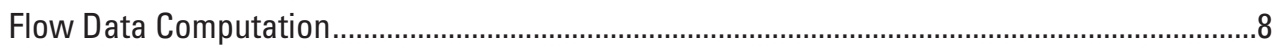

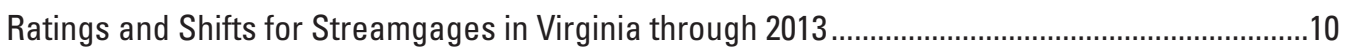

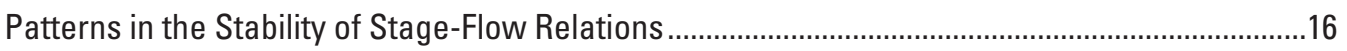

Development of Long-Term Average Ratings .....................................................................16

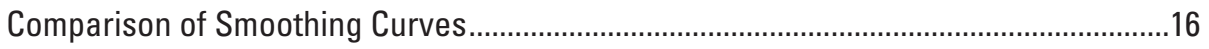

Classification of Rating Families ................................................................................ 18

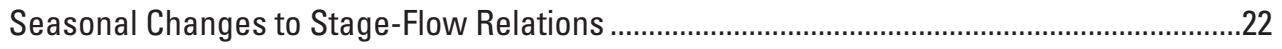

Long-Term Changes to Stage-Flow Relations ....................................................................22

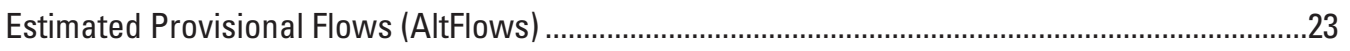

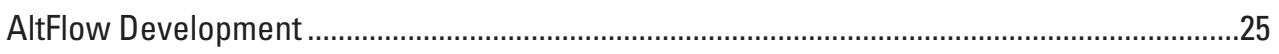

Rating Availability, Acquisition, and Compilation .........................................................25

Special Conditions Affecting Some AltFlows..............................................................26

Streamgage Datum Changes ...............................................................................

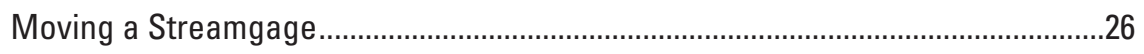

Suspension of Streamgage Operations ...............................................................2

Estimated and Qualified Daily Flows .......................................................................27

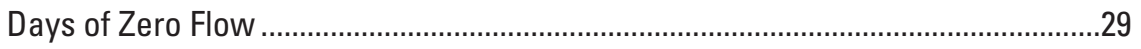

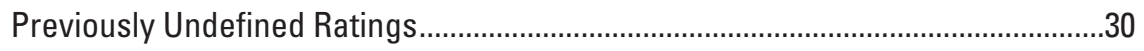

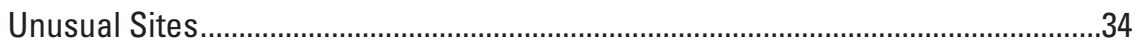

Comparison of Ratings and Measurements as a Check on Rating Compilation ..............34

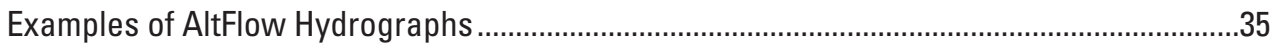

Stability Metrics and Their Relations to Each Other and to Basin Characteristics.........................35

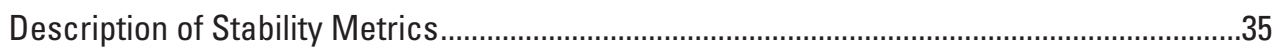

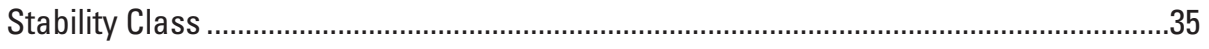

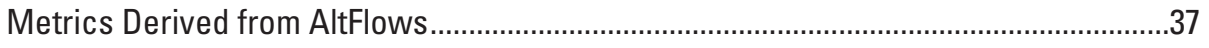

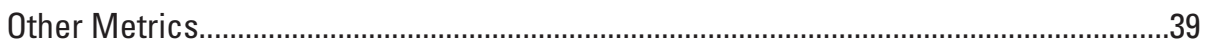

Relations Among Stability Metrics ................................................................................ 40

Stability Metrics and their Relations to Site and Basin Characteristics ................................4

Caveats, Limitations, and Suggestions for Further Study ............................................................4

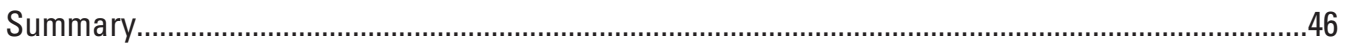

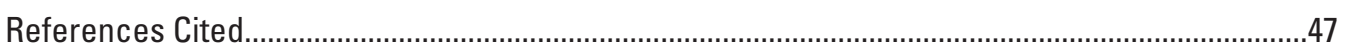

Appendix 1. Plots for real-time streamgages in Virginia ……...................................................8

Appendix 2. Computation of Alternative Flow Data ...................................................................

Appendix 3. UNIX shell scripts used to develop AltFlow record..................................................90

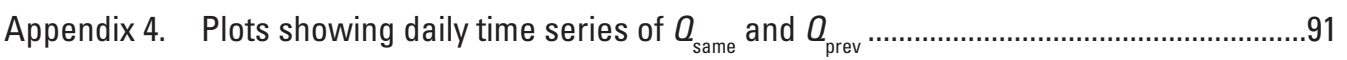




\section{Plates}

1. A, Long-term stage-flow relations at selected streamgages in Virginia with a generalized additive model smoother, $B$, seasonal variation of relations between residual of flow and date with a LOESS smoother, and $C$, seasonal variation of relations between residual of flow and Julian date with a LOESS smoother available online

2. Patterns of variation in, $A$, long-term stage-flow relations at selected streamgages in Virginia, $B$, residual of flow and date with a LOESS smoother, and $C$, residual of flow and Julian date with a LOESS smoother... available online

3. AltFlow hydrographs for four selected streamgages in Virginia, water years 1991-2013. available online

4. Matrix of proposed stability metrics developed using daily flow, shifted ratings, and flow measurements for streamgages in Virginia, water years 1991-2013. available online

5. Scatterplot matrixes of stage-flow relation stability metrics in relation to selected basin characteristics for $A, 64$ plots and, $B, 88$ plots, for streamgages in Virginia, water years 1991-2013. available online

\section{Figures}

1. Maps showing elevation, physiographic provinces, streams, and streamgages active as of September 30, 2013, in Virginia.

2. Graph showing relation between start dates of shifts and dates of final modification of shifts at streamgages in Virginia, water years 1991-2013

3. Boxplot showing number of days between start and final modification of shifts at streamgages in Virginia, 1990-2013.

4. Graphs showing rating curves for stage-flow relations for streamgage 01634000 , North Fork Shenandoah River at Strasburg, VA, with six smoothers applied: $A$, linear regression, $B$, Gaussian LOESS, $C$, LOESS, symmetric $0.75, D$, LOESS symmetric $0.5, E$, LOESS, symmetric 0.25 , and $F$, generalized additive model..

5. Graphs showing streamgage 01668000, Rappahannock River near Fredericksburg, $V A$, showing: $A$, long-term stage-flow relations with a generalized additive model smoother, $B$, residual of flow and date with a LOESS smoother, and $C$, residual of flow and Julian date with a LOESS smoother

6. Boxplots showing distribution of variability metrics for stage-flow relations, by descriptive stability class, for streamgages in Virginia active on September 30, 2013

7. Flowchart of major actions and data sources for computing alternative flow tables for Virginia streams, water years 1991-2013

8. Boxplots showing distribution of proposed stage-flow relation stability and real-time flow reliability metrics by descriptive stability class for streamgages in Virginia active on September 30, 2013 


\section{Tables}

1. Virginia streamgage numbers, names, drainage areas, locations, and elevations ..........4

2. Earliest dates for base ratings and shifts in the Virginia node of the National Water Information System database for streamgages active as of September 30, 2013..........49

3. Number of unique shifts recorded in the National Water Information System at streamgages in Virginia active as of September 30, 2013; includes multiple shifts begun on the same day.

4. Number of base ratings and number of days they were in effect for streamgages in Virginia, water years 1991-2013, for periods when the ratings were stored in the National Water Information System.

5. Selected characteristics of daily flows on days that base ratings began at streamgages in Virginia, water years 1991-2013.

6. Selected characteristics of daily flows on days that shifts began at streamgages in Virginia, water years 1991-2013.

7. Dates on which shifts began at 30 or more streamgages, and flow characteristics for that day at the streamgage in question in Virginia, water years 1991-2013. 13

8. Hydrographer descriptions of controls for streamgages in Virginia at which real-time flow data were collected as of September 30, 2013, and descriptions of associated features of interest available online

9. Rating families, dates they were in effect, variability statistics, and explanations for their causes for streamgages active in Virginia in October 2013.

10. Locations, magnitudes, and dates of datum changes for streamgages in Virginia, water years 1990-2013.

11. Streamgages that were moved to new gaging pools, and dates of the move, in Virginia, water years 1991-2013.

12. Virginia streamgages that were discontinued and reactivated for 30 or more consecutive days, and the dates they were discontinued and reactivated, water years 1991-2013.

13. Number of days with estimated and qualified flows for streamgages in Virginia, water years 1991-2013.

14. Number of days with zero flow for streamgages in Virginia, water years 1991-2013

15. Number of days when $Q_{\text {same }}$ equaled zero but $Q_{\text {prev }}$ did not, and mean and maximum values of $Q_{\text {prev }}$ for those days for streamgages in Virginia, water years 1991-2013.

16. Number of days when $Q_{\text {prev }}$ equaled zero but $Q_{\text {same }}$ did not, with mean and maximum values of $Q_{\text {prev }}$ for those days for streamgages in Virginia, water years 1991-2013.

17. Number of times ratings entered ranges that had been undefined in the previous actual rating and set equal to the defined rating minimum for the purpose of this analysis, and number of days they were in such ranges for streamgages in Virginia, water years 1991-2013.

18. Days of approved flow record less than their respective rating minima for streamgages in Virginia, water years 1991-2013.

19. Number of comparisons of directly measured flow to the rating in effect at the time of measurement relative to divergence thresholds for streamgages in Virginia, water years 1991-2013.

20. Summary of selected rating stability metrics for streamgages in Virginia, water years 1991-2013. available online 
21. Number of days of available $Q_{\text {prev }}$ record for streamgages in Virginia, by streamgage and month, and earliest date the records are available, during water years 1991-2013.

22. Control and rating stability assessments made by senior hydrographers in the Virginia Water Science Center and Virginia Department of Environmental Quality for streamgages in Virginia active September 30, 2013.

23. Instructions to senior hydrographers for answering a control and rating stability questionnaire, for Virginia streamgages active September 30, 2013.

24. Average of daily percent errors for flow in Virginia streams, by month and percentile range available online

25. Root-mean-square error of AltFlows and number of days of record for streamgages on Virginia streams by month and percentile of monthly flow, water years 1991-2013 available online

26. Proportion of days when the difference between Oprev and Osame was zero at streamgages in Virginia, by month, 1990-2013. available online

27. Correlation matrix of Spearman's rho correlation coefficients for proposed rating-stability metrics developed from daily flows, shifted ratings, and flow measurements for streamgages in Virginia, water years 1991-2013

28. Correlation matrix of Spearman's rho correlation coefficients for selected rating stability metrics and selected basin characteristics for streamgages active in Virginia, September 30, 2013 


\section{Conversion Factors}

U.S. customary units to International System of Units

\begin{tabular}{lcl}
\hline \multicolumn{1}{c}{ Multiply } & By & \multicolumn{1}{c}{ To obtain } \\
\hline & Length & \\
\hline foot $(\mathrm{ft})$ & 0.3048 & meter $(\mathrm{m})$ \\
mile $(\mathrm{mi})$ & 1.609 & kilometer $(\mathrm{km})$ \\
\hline \multicolumn{3}{c}{ Area } \\
\hline square mile $\left(\mathrm{mi}^{2}\right)$ & 259.0 & hectare $($ ha) \\
square mile $\left(\mathrm{mi}^{2}\right)$ & 2.590 & square kilometer $\left(\mathrm{km}^{2}\right)$ \\
\hline & Flow rate & \\
\hline cubic foot per second $\left(\mathrm{ft}^{3} / \mathrm{s}\right)$ & 0.02832 & cubic meter per second $\left(\mathrm{m}^{3} / \mathrm{s}\right)$ \\
\hline
\end{tabular}

\section{Datum}

Vertical coordinate information is referenced to the North American Vertical Datum of 1988 (NAVD 88).

Horizontal coordinate information is referenced to the North American Datum of 1983 (NAD 83).

Elevation, as used in this report, refers to distance above the vertical datum.

\section{Abbreviations}

$\begin{array}{ll}\text { GAM } & \text { Generalized additive model } \\ \text { NWIS } & \text { National Water Information System } \\ \text { RMSE } & \text { Root-mean-square error } \\ \text { USGS } & \text { U.S. Geological Survey } \\ \text { VDEO } & \text { Virginia Department of Environmental Quality }\end{array}$




\title{
Rating Stability, and Frequency and Magnitude of Shifts, for Streamgages in Virginia Through Water Year 2013
}

\author{
Terence Messinger ${ }^{1}$ and Robert W. Burgholzer ${ }^{2}$
}

\section{Abstract}

The U.S. Geological Survey, in cooperation with the Virginia Department of Environmental Quality, has quantified several measures of rating stability and the frequency and magnitude of changes to ratings through time for 174 real-time continuous streamgages active in Virginia as of September 30, 2013. Generalized additive models (GAMs) were fitted through all available flow measurements for all the streamgages in Virginia's real-time network as of September 30, 2013, with at least 20 flow measurements with positive flow values. For each measurement with a positive flow value, residuals from the GAM curve were calculated. Time series of these residuals were used to identify major changes to the control (the stream feature or features which control the relation between stage and flow); the measurements in the periods of equilibrium between major changes were assigned to rating families. Of the 127 rating families that were identified as being distinct at sites, documented explanations were found for 67 of them. The most common reasons for the control to change enough to warrant a new rating family are moving the streamgage (28 times), floods (26 times), and construction activities (13 times). Provisional flow data from any streamgage that has recently experienced a major flood, regardless of historical stability, are more uncertain than usual until post-flood evidence emerges that the rating is stable, or if the rating has changed, until it is known to be well defined.

A direct comparison between provisional flow data (those data originally displayed on the web in near-real time) and flow data approved for publication following subsequent flow measurements and review could not be made because provisional flow data have not been archived. As a substitute, alternative flow (AltFlow) tables were constructed for periods with complete records of shifts and ratings. Alternate flows consist of $Q_{\text {same }}$, the flow value from the shifted rating table used to compute the daily flow value at the time of the most

${ }^{1}$ U.S. Geological Survey

${ }^{2}$ Virginia Department of Environmental Quality recent flow measurement that corresponds to the gage height of each day's daily flow value, and $Q_{\text {prev }}$, the flow value from the shifted rating table in effect at the time of the previous flow measurement that corresponds to the gage height of each day's daily flow value.

Several metrics that summarize AltFlow tables were computed and evaluated; particular importance was given to how well the metrics agreed with the descriptive stability class developed from interviews with hydrographers. Of these stability metrics, at least four were determined to be meaningful and to represent different aspects of control stability that might be relevant to water managers: total root mean square error between log-transformed $Q_{\text {prev }}$ and $Q_{\text {same }}$, percentage of days when the difference between $Q_{\text {prev }}$ and $Q_{\text {same }}$ is greater than ( $>$ ) $Q_{\text {same }}$, the sum of absolute AltFlow error divided by total flow, and percentage of days with zero difference between $Q_{\text {prev }}$ and $Q_{\text {same }}$.

Three other meaningful metrics of control stability or provisional flow-data quality were computed: $\mathrm{R}^{2}$ (coefficient of determination) of GAMs from the flow measurements, percentage of total estimated days, and percentage of estimated days in the winter. Correlations among metrics varied, indicating they responded to different aspects of control stability. Relations among the various stability metrics and quantitative basin and site characteristics were weak. Although quantitative relations between stability metrics and basin and site characteristics were all weak, some common patterns still emerged. Controls and ratings on large streams $\left[>500\right.$-square mile $\left(\mathrm{mi}^{2}\right)$ drainage area] and at high elevations ( $>1,000$ feet) were more likely to be stable than controls and ratings on small streams (less than $(<)$ 100-mi ${ }^{2}$ drainage area) and at low elevations $(<500$ feet). There were exceptions to both generalizations, and streamgages that were intermediate in both characteristics varied widely in stability.

Typical timing of record computation changed during water years 1991-2013. From 1991 through 2001, the median number of days between the start date of the shift and the date it was created fluctuated between about 240 and about 300 days and decreased by about 4 months from 2001 to 2002 . Only in 2012 and 2013 did one-half of the shifts have a delay of about 60 days between start date and final modification. 


\section{Introduction}

The U.S. Geological Survey (USGS) began posting flow data on the internet in near real time in 1994, during a time when streamgages equipped with satellite telemetry increased from 14 percent in 1983 to 64 percent in 1997 (U.S. Geological Survey, 1998). Since then, many emergency responders, water managers, anglers, boaters, and others increasingly have come to rely on the accuracy of real-time flow data to make decisions that affect the safety of life and property.

Continuous flow typically is not measured directly. Instead, it is computed from stage measurements using a "rating curve," or a curve fitted through points representing the direct measurements of stage and flow that are made during periodic streamgage inspections. At all streamgages, rating curves change through time as a result of changes to "controls," the bed or channel features that control the water level in the gaging pool. The gaging pool is the pool of water where stage, or gage height, is measured. The stability of controls varies greatly among streamgages. Changes to controls can be determined only by inspection or measurement, can be quantified only by measurement, and are the reason periodic flow measurements are made. Reliability of real-time flow data depends primarily on the stability of the control. Other factors are also important, however, notably how prone the streamgage intake or orifice is to sediment deposition. Changes to controls that require several flow measurements to define are common.

The USGS, in cooperation with the Virginia Department of Environmental Quality (VDEQ), has quantified several measures of rating stability and the frequency and magnitude of changes to ratings through time for 174 real-time continuous streamgages active in Virginia as of October 2013. This study is intended to help water managers understand how much confidence may be placed in preliminary flow data collected at these streamgages.

\section{Purpose and Scope}

The purpose of this report is to describe the steps taken to quantify the stability of stage-flow ratings for streams in Virginia, to help evaluate the reliability of the ratings to provide real-time flow data. Two different analytical approaches are employed. (1) Flow measurements are compared to long-term average ratings by flow, date, and day-of-year, and (2) mean daily flows for water years ${ }^{1} 1991-2013$ are compared to flows that would have been computed from the rating in effect when the previous flow measurement was made. Stability metrics including root mean square error (RMSE), percent error, and days with zero differences are computed for these two sets of flows and are presented in total and by month and flow

\footnotetext{
${ }^{1} \mathrm{~A}$ water year is the 12 -month period from October 1 to September 30. It is designated by the year in which it ends.
}

percentile. Efforts are made to correlate the stability metrics with stream and basin characteristics.

\section{Description of the Virginia Streamgage Network}

One hundred seventy-four real-time streamgages were active in Virginia as of September 30, 2013, the end of the study period (table 1, fig. 1). At that time, streamgages in Virginia were operated by three field offices, two USGS offices in Richmond and Marion, and a VDEQ office in Charlottesville. The VDEQ and, before it, the Virginia Water-Control Board, has been operating streamgages according to USGS specifications and protocols for decades. Data collected by both organizations are treated as interchangeable and as meeting the same quality standards. Streamgages are traded between the two organizations on an irregular basis related partly to operational considerations, such as funding and staffing, and to differences in the missions of the two agencies. No distinction is made between data collected by the two organizations in interpretive products, such as peak-flow and low-flow regression equations. The USGS opened a new field office in Leetown, West Virginia, in 2014, after the end of the study period.

Virginia's environmental setting has been described in detail previously (Hayes, 1989; Nelms and others, 1997; Nelms and others, 2003). Aspects of the environmental setting discussed in those reports that are relevant to this study include physiography, elevation, land use, and interactions among them.

\section{Streamgaging Operations}

The USGS collects flow data using a clearly defined set of field and office procedures. Although procedures have changed through time, they have been documented since the 1900s (Murphy and others, 1904; Corbett and others, 1943; Rantz and others, 1982; Sauer and Turnipseed, 2010; Turnipseed and Sauer, 2010). Development of stage-flow ratings and shifts (temporary ratings) that reflect controls and changes to them are a key part of the flow data collection and computation procedure.

\section{General Field and Office Procedures}

Streamgaging field procedures have been developed to enable the USGS to collect complete and accurate stage data and maintain the stage-flow ratings, including documenting changes to it through time. This requires that hydrographers, the technicians and scientists who collect and compute flow data, make flow measurements and maintain streamgages at regular intervals.

Stage is recorded continuously using a variety of technologies. The USGS in Virginia measures stage using a variety of sensors, including stilling wells with float-driven recorders, 


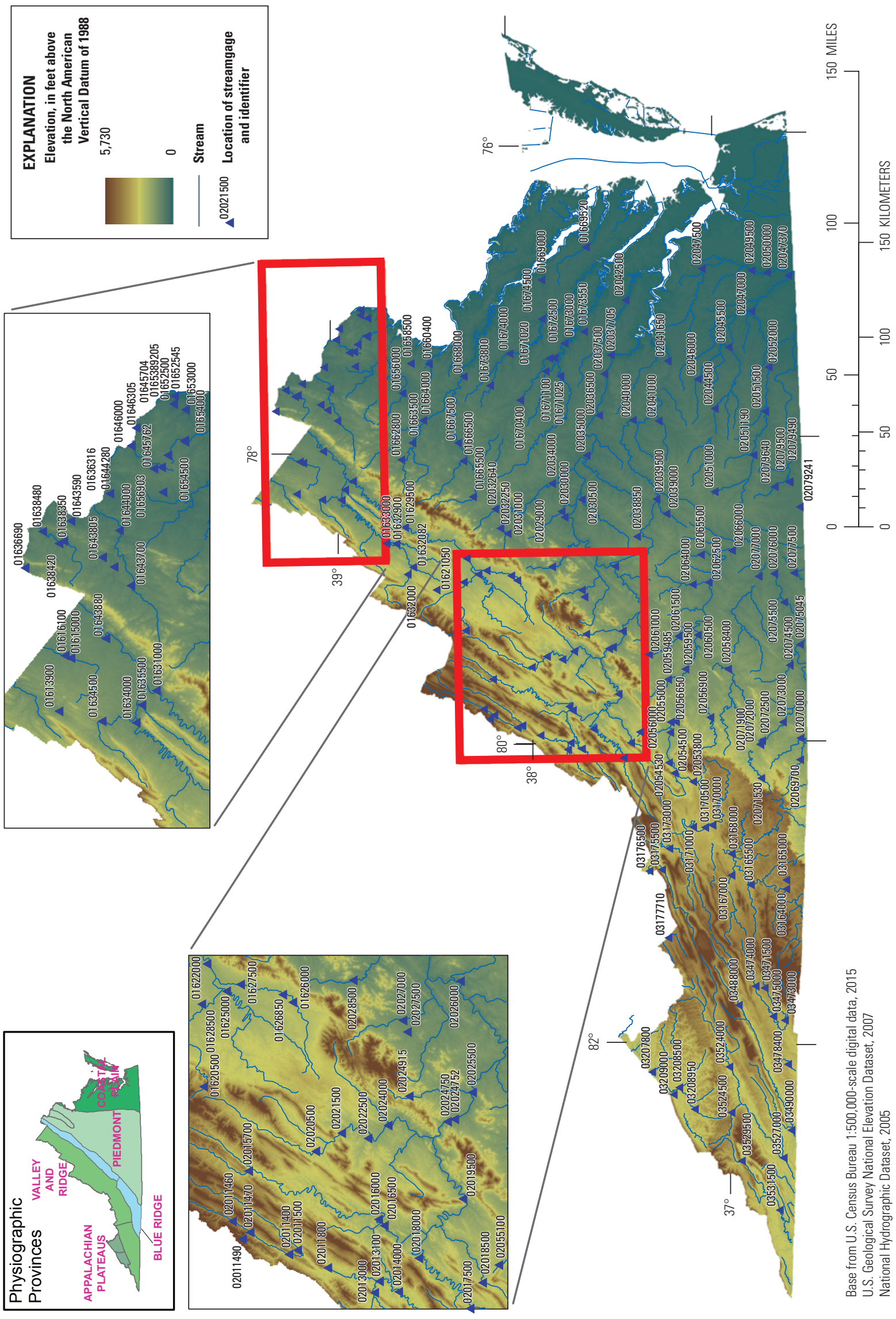

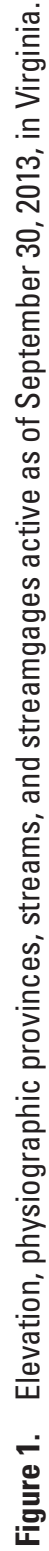


Table 1. Virginia streamgage numbers, names, drainage areas, locations, and elevations.

[mi², square miles; dd, decimal degrees; ft, feet; -, undefined; VA, Virginia; Rt, Route]

\begin{tabular}{|c|c|c|c|c|c|}
\hline $\begin{array}{l}\text { Streamgage } \\
\text { number }\end{array}$ & Streamgage name & $\begin{array}{c}\text { Drainage area } \\
\left(\mathrm{mi}^{2}\right)\end{array}$ & $\begin{array}{l}\text { Latitude } \\
\text { (dd) }\end{array}$ & $\begin{array}{l}\text { Longitude } \\
\text { (dd) }\end{array}$ & $\begin{array}{c}\text { Elevation of gage } \\
(\mathrm{ft})\end{array}$ \\
\hline 01613900 & Hogue Creek near Hayfield, VA & 15.9 & 39.2145 & -78.2881 & 669 \\
\hline 01615000 & Opequon Creek near Berryville, VA & 58.2 & 39.1747 & -78.0783 & 503 \\
\hline 01616100 & Dry Marsh Run near Berryville, VA & 11.0 & 39.1926 & -78.0686 & 501 \\
\hline 01620500 & North River near Stokesville, VA & 17.3 & 38.335 & -79.2392 & 2,051 \\
\hline 01621050 & Muddy Creek at Mount Clinton, VA & 14.3 & 38.4868 & -78.9603 & 1,360 \\
\hline 01622000 & North River near Burketown, VA & 376 & 38.3404 & -78.9136 & 1,103 \\
\hline 01625000 & Middle River near Grottoes, VA & 373 & 38.2618 & -78.8620 & 1,062 \\
\hline 01626000 & South River near Waynesboro, VA & 127 & 38.0576 & -78.9081 & 1,296 \\
\hline 01626850 & South River near Dooms, VA & 148 & 38.0887 & -78.8770 & 1,247 \\
\hline 01627500 & South River at Harriston, VA & 212 & 38.2187 & -78.8367 & 1,130 \\
\hline 01628500 & South Fork Shenandoah River near Lynnwood, VA & 1,079 & 38.3226 & -78.7547 & 1,002 \\
\hline 01629500 & South Fork Shenandoah River near Luray, VA & 1,372 & 38.6462 & -78.5347 & 722 \\
\hline 01631000 & South Fork Shenandoah River at Front Royal, VA & 1,634 & 38.9140 & -78.2108 & 469 \\
\hline 01632000 & North Fork Shenandoah River at Cootes Store, VA & 210 & 38.6371 & -78.8528 & 1,051 \\
\hline 01632082 & Linville Creek at Broadway, VA & 45.7 & 38.6068 & -78.8034 & 1,030 \\
\hline 01632900 & Smith Creek near New Market, VA & 93.6 & 38.6935 & -78.6428 & 881 \\
\hline 01633000 & North Fork Shenandoah River at Mount Jackson, VA & 508 & 38.7457 & -78.6389 & 839 \\
\hline 01634000 & North Fork Shenandoah River near Strasburg, VA & 770 & 38.9768 & -78.3361 & 493 \\
\hline 01634500 & Cedar Creek near Winchester, VA & 102 & 39.0812 & -78.3294 & 647 \\
\hline 01635500 & Passage Creek near Buckton, VA & 86.5 & 38.9582 & -78.2667 & 525 \\
\hline 01636316 & Spout Run at Rt 621 near Millwood, VA & 21.4 & 39.0670 & -78.0038 & 430 \\
\hline 01636690 & Piney Run near Lovettsville, VA & 13.5 & 39.3108 & -77.7185 & 397 \\
\hline 01638350 & South Fork Catoctin Creek at Rt 698 near Waterford, VA & 31.6 & 39.1911 & -77.6154 & 336 \\
\hline 01638420 & North Fork Catoctin Creek at Rt 681 near Waterford, VA & 23.1 & 39.205 & -77.6239 & 325 \\
\hline 01638480 & Catoctin Creek at Taylorstown, VA & 89.5 & 39.2551 & -77.5764 & 247 \\
\hline 01643590 & Limestone Branch near Leesburg, VA & 7.88 & 39.1676 & -77.5359 & 220 \\
\hline 01643700 & Goose Creek near Middleburg, VA & 122 & 38.9865 & -77.7967 & 327 \\
\hline 01643805 & North Fork Goose Creek at Rt 729 near Lincoln, VA & 38.1 & 39.0723 & -77.6839 & 295 \\
\hline 01643880 & Beaverdam Creek at Rt 734 near Mountville, VA & 47.2 & 39.0377 & -77.7223 & 307 \\
\hline 01644000 & Goose Creek near Leesburg, VA & 332 & 39.0196 & -77.5775 & 249 \\
\hline 01644280 & Broad Run near Leesburg, VA & 76.1 & 39.0464 & -77.4324 & 194 \\
\hline 01645704 & Difficult Run above Fox Lake near Fairfax, VA & 5.49 & 38.8847 & -77.3324 & 296 \\
\hline 01645762 & South Fork Little Difficult Run above Mouth near Vienna, VA & 2.71 & 38.9089 & -77.3383 & 274 \\
\hline 01646000 & Difficult Run near Great Falls, VA & 57.8 & 38.9759 & -77.2458 & 151 \\
\hline 01646305 & Dead Run at Whann Avenue near Mclean, VA & 2.05 & 38.9598 & -77.1757 & 178 \\
\hline 01652500 & Fourmile Run at Alexandria, VA & 12.6 & 38.8433 & -77.0859 & 29 \\
\hline 01653000 & Cameron Run at Alexandria, VA & 33.9 & 38.8065 & -77.1097 & 32 \\
\hline 0165389205 & Accotink Creek near Ranger Road at Fairfax, VA & 3.99 & 38.8662 & -77.2864 & 296 \\
\hline 01654000 & Accotink Creek near Annandale, VA & 23.9 & 38.8129 & -77.2283 & 191 \\
\hline 01656000 & Cedar Run near Catlett, VA & 93.4 & 38.6368 & -77.6250 & 199 \\
\hline 01656903 & Flatlick Branch above Frog Branch at Chantilly, VA & 4.20 & 38.8824 & -77.4319 & 257 \\
\hline 01658500 & South Fork Quantico Creek near Independent Hill, VA & 7.62 & 38.5873 & -77.4286 & 238 \\
\hline 01660400 & Aquia Creek near Garrisonville, VA & 35.0 & 38.4904 & -77.4336 & 120 \\
\hline 01662800 & Battle Run near Laurel Mills, VA & 25.8 & 38.6557 & -78.0739 & 375 \\
\hline 01663500 & Hazel River at Rixeyville, VA & 285 & 38.5918 & -77.9650 & 288 \\
\hline
\end{tabular}


Table 1. Virginia streamgage numbers, names, drainage areas, locations, and elevations.-Continued

[mi² , square miles; dd, decimal degrees; ft, feet; —, undefined; VA, Virginia; Rt, Route]

\begin{tabular}{|c|c|c|c|c|c|}
\hline $\begin{array}{c}\text { Streamgage } \\
\text { number }\end{array}$ & Streamgage name & $\begin{array}{c}\text { Drainage area } \\
\left(\mathrm{mi}^{2}\right)\end{array}$ & $\begin{array}{l}\text { Latitude } \\
\text { (dd) }\end{array}$ & $\begin{array}{l}\text { Longitude } \\
\text { (dd) }\end{array}$ & $\begin{array}{c}\text { Elevation of gage } \\
\text { (ft) }\end{array}$ \\
\hline 01664000 & Rappahannock River at Remington, VA & 619 & 38.5307 & -77.8136 & 252 \\
\hline 01665500 & Rapidan River near Ruckersville, VA & 115 & 38.2807 & -78.3400 & 439 \\
\hline 01666500 & Robinson River near Locust Dale, VA & 179 & 38.3251 & -78.0956 & 284 \\
\hline 01667500 & Rapidan River near Culpeper, VA & 468 & 38.3504 & -77.9750 & 241 \\
\hline 01668000 & Rappahannock River near Fredericksburg, VA & 1,595 & 38.3085 & -77.5292 & 70 \\
\hline 01669000 & Piscataway Creek near Tappahannock, VA & 27.9 & 37.8771 & -76.9005 & 1 \\
\hline 01669520 & Dragon Swamp at Mascot, VA & 109 & 37.6338 & -76.6963 & 22 \\
\hline 01670400 & North Anna River near Partlow, VA & 342 & 38.0129 & -77.7011 & 167 \\
\hline 01671020 & North Anna River at Hart Corner near Doswell, VA & 462 & 37.8501 & -77.4278 & 43 \\
\hline 01671025 & North Anna River above Little River near Doswell, VA & 467 & 37.8257 & -77.4261 & 35 \\
\hline 01671100 & Little River near Doswell, VA & 107 & 37.8726 & -77.5130 & 132 \\
\hline 01672500 & South Anna River near Ashland, VA & 395 & 37.7968 & -77.5489 & 83 \\
\hline 01673000 & Pamunkey River near Hanover, VA & 1,078 & 37.7676 & -77.3322 & 14 \\
\hline 01673550 & Totopotomoy Creek near Studley, VA & 25.5 & 37.6626 & -77.2578 & 38 \\
\hline 01673800 & Po River near Spotsylvania, VA & 77.6 & 38.1715 & -77.5947 & 184 \\
\hline 01674000 & Mattaponi River near Bowling Green, VA & 256 & 38.0618 & -77.3858 & 84 \\
\hline 01674500 & Mattaponi River near Beulahville, VA & 603 & 37.8839 & -77.1653 & 11 \\
\hline 02011400 & Jackson River near Bacova, VA & 157 & 38.0423 & -79.8814 & 1,639 \\
\hline 02011460 & Back Creek near Sunrise, VA & 60.9 & 38.2454 & -79.7687 & 2,200 \\
\hline 02011470 & Back Creek at Sunrise, VA & 75.6 & 38.1904 & -79.8117 & 1,968 \\
\hline 02011490 & Little Back Creek near Sunrise, VA & 4.90 & 38.2146 & -79.8376 & 2,638 \\
\hline 02011500 & Back Creek near Mountain Grove, VA & 134 & 38.0696 & -79.8970 & 1,701 \\
\hline 02011800 & Jackson River below Gathright Dam near Hot Spgs, VA & 345 & 37.9485 & -79.9492 & 1,400 \\
\hline 02013000 & Dunlap Creek near Covington, VA & 162 & 37.8029 & -80.0470 & 1,294 \\
\hline 02013100 & Jackson River below Dunlap Creek at Covington, VA & 612 & 37.7887 & -80.0006 & 1,206 \\
\hline 02014000 & Potts Creek near Covington, VA & 153 & 37.7290 & -80.0423 & 1,273 \\
\hline 02015700 & Bullpasture River at Williamsville, VA & 110 & 38.1954 & -79.5703 & 1,610 \\
\hline 02016000 & Cowpasture River near Clifton Forge, VA & 461 & 37.7918 & -79.7595 & 1,007 \\
\hline 02016500 & James River at Lick Run, VA & 1,371 & 37.7737 & -79.7845 & 978 \\
\hline 02017500 & Johns Creek at New Castle, VA & 105 & 37.5062 & -80.1067 & 1,254 \\
\hline 02018000 & Craig Creek at Parr, VA & 329 & 37.6660 & -79.9114 & 992 \\
\hline 02018500 & Catawba Creek near Catawba, VA & 34.3 & 37.4682 & -80.0053 & 1,300 \\
\hline 02019500 & James River at Buchanan, VA & 2,073 & 37.5307 & -79.6789 & 802 \\
\hline 02020500 & Calfpasture River above Mill Creek at Goshen, VA & 141 & 37.9879 & -79.4937 & 1,383 \\
\hline 02021500 & Maury River at Rockbridge Baths, VA & 329 & 37.9074 & -79.4220 & 1,100 \\
\hline 02022500 & Kerrs Creek near Lexington, VA & 35.1 & 37.8257 & -79.4431 & 980 \\
\hline 02024000 & Maury River near Buena Vista, VA & 647 & 37.7626 & -79.3914 & 846 \\
\hline 02024752 & James River at Blue Ridge Pkwy near Big Island, VA & 3,076 & 37.5554 & -79.3673 & 601 \\
\hline 02024915 & Pedlar River at Forest Road near Buena Vista, VA & 27.1 & 37.6975 & -79.2783 & 1,135 \\
\hline 02025500 & James River at Holcomb Rock, VA & 3,256 & 37.5013 & -79.2625 & 548 \\
\hline 02026000 & James River at Bent Creek, VA & 3,649 & 37.5363 & -78.8295 & 380 \\
\hline 02027000 & Tye River near Lovingston, VA & 93.0 & 37.7154 & -78.9817 & 575 \\
\hline 02027500 & Piney River at Piney River, VA & 47.7 & 37.7024 & -79.0275 & 632 \\
\hline 02028500 & Rockfish River near Greenfield, VA & 94.8 & 37.8696 & -78.8234 & 532 \\
\hline 02029000 & James River at Scottsville, VA & 4,581 & 37.7974 & -78.4914 & 252 \\
\hline
\end{tabular}


Table 1. Virginia streamgage numbers, names, drainage areas, locations, and elevations.-Continued [mi², square miles; dd, decimal degrees; ft, feet; -, undefined; VA, Virginia; Rt, Route]

\begin{tabular}{|c|c|c|c|c|c|}
\hline $\begin{array}{c}\text { Streamgage } \\
\text { number }\end{array}$ & Streamgage name & $\begin{array}{c}\text { Drainage area } \\
\left(\mathrm{mi}^{2}\right)\end{array}$ & $\begin{array}{l}\text { Latitude } \\
\text { (dd) }\end{array}$ & $\begin{array}{l}\text { Longitude } \\
\text { (dd) }\end{array}$ & $\begin{array}{c}\text { Elevation of gage } \\
\text { (ft) }\end{array}$ \\
\hline 02030000 & Hardware River below Briery Run near Scottsville, VA & 116 & 37.8126 & -78.4553 & 295 \\
\hline 02030500 & Slate River near Arvonia, VA & 226 & 37.7029 & -78.3775 & 239 \\
\hline 02031000 & Mechums River near White Hall, VA & 95.3 & 38.1026 & -78.5928 & 430 \\
\hline 02032250 & Moormans River near Free Union, VA & 77.0 & 38.1407 & -78.5558 & 403 \\
\hline 02032640 & North Fork Rivanna River near Earlysville, VA & 108 & 38.1635 & -78.4247 & 365 \\
\hline 02034000 & Rivanna River at Palmyra, VA & 663 & 37.8579 & -78.2658 & 210 \\
\hline 02035000 & James River at Cartersville, VA & 6,252 & 37.6710 & -78.0858 & 164 \\
\hline 02036500 & Fine Creek at Fine Creek Mills, VA & 22.4 & 37.5979 & -77.8197 & 157 \\
\hline 02037000 & James River And Kanawha Canal near Richmond, VA & - & 37.5646 & -77.5742 & 106 \\
\hline 02037500 & James River near Richmond, VA & 6,753 & 37.5632 & -77.5469 & 99 \\
\hline 02038850 & Holiday Creek near Andersonville, VA & 8.54 & 37.4154 & -78.6358 & 473 \\
\hline 02039000 & Buffalo Creek near Hampden Sydney, VA & 69.6 & 37.2571 & -78.4864 & 339 \\
\hline 02039500 & Appomattox River at Farmville, VA & 302 & 37.3071 & -78.3886 & 281 \\
\hline 02040000 & Appomattox River at Mattoax, VA & 725 & 37.4215 & -77.8589 & 175 \\
\hline 02040892 & Appomattox River at Route 602 near Mannboro, VA & 942 & 37.3181 & -77.8017 & 161 \\
\hline 02041000 & Deep Creek near Mannboro, VA & 158 & 37.2832 & -77.8697 & 177 \\
\hline 02041650 & Appomattox River at Matoaca, VA & 1,342 & 37.2252 & -77.4753 & 68 \\
\hline 02042500 & Chickahominy River near Providence Forge, VA & 251 & 37.4363 & -77.0608 & 5 \\
\hline 02044500 & Nottoway River near Rawlings, VA & 317 & 36.9835 & -77.7997 & 185 \\
\hline 02045500 & Nottoway River near Stony Creek, VA & 577 & 36.9001 & -77.3997 & 58 \\
\hline 02046000 & Stony Creek near Dinwiddie, VA & 113 & 37.0671 & -77.6025 & 130 \\
\hline 02047000 & Nottoway River near Sebrell, VA & 1,441 & 36.7704 & -77.1661 & 5 \\
\hline 02047500 & Blackwater River near Dendron, VA & 290 & 37.0251 & -76.8747 & 0 \\
\hline 02049500 & Blackwater River near Franklin, VA & 613 & 36.7626 & -76.8983 & 0 \\
\hline 02051000 & North Meherrin River near Lunenburg, VA & 56.0 & 36.9974 & -78.3497 & 334 \\
\hline 02051500 & Meherrin River near Lawrenceville, VA & 552 & 36.7168 & -77.8317 & 137 \\
\hline 02052000 & Meherrin River at Emporia, VA & 744 & 36.6901 & -77.5405 & 67 \\
\hline 02053800 & South Fork Roanoke River near Shawsville, VA & 109 & 37.1401 & -80.2664 & 1,362 \\
\hline 02054500 & Roanoke River at Lafayette, VA & 254 & 37.2365 & -80.2092 & 1,174 \\
\hline 02054530 & Roanoke River at Glenvar, VA & 281 & 37.2679 & -80.1395 & 1,100 \\
\hline 02055000 & Roanoke River at Roanoke, VA & 384 & 37.2585 & -79.9386 & 906 \\
\hline 02055100 & Tinker Creek near Daleville, VA & 11.7 & 37.4176 & -79.9353 & 1,212 \\
\hline 02056000 & Roanoke River at Niagara, VA & 509 & 37.2551 & -79.8714 & 820 \\
\hline 02056650 & Back Creek near Dundee, VA & 55.8 & 37.2276 & -79.8681 & 823 \\
\hline 02056900 & Blackwater River near Rocky Mount, VA & 115 & 37.0451 & -79.8442 & 876 \\
\hline 02058400 & Pigg River near Sandy Level, VA & 351 & 36.9460 & -79.5248 & 616 \\
\hline 02059485 & Goose Creek at Rt 747 near Bunker Hill, VA & 125 & 37.2664 & -79.5878 & 704 \\
\hline 02059500 & Goose Creek near Huddleston, VA & 188 & 37.1732 & -79.5203 & 593 \\
\hline 02060500 & Roanoke River at Altavista, VA & 1,782 & 37.1046 & -79.2953 & 502 \\
\hline 02061000 & Big Otter River near Bedford, VA & 114 & 37.3640 & -79.4192 & 670 \\
\hline 02061500 & Big Otter River near Evington, VA & 315 & 37.2085 & -79.3036 & 544 \\
\hline 02062500 & Roanoke (Staunton) River at Brookneal, VA & 2,404 & 37.0394 & -78.9457 & 351 \\
\hline 02064000 & Falling River near Naruna, VA & 165 & 37.1268 & -78.9597 & 412 \\
\hline 02065500 & Cub Creek at Phenix, VA & 97.6 & 37.0793 & -78.7636 & 370 \\
\hline 02066000 & Roanoke (Staunton) River at Randolph, VA & 2,966 & 36.9151 & -78.7408 & 308 \\
\hline
\end{tabular}


Table 1. Virginia streamgage numbers, names, drainage areas, locations, and elevations.-Continued [mi², square miles; dd, decimal degrees; $\mathrm{ft}$, feet; - , undefined; VA, Virginia; Rt, Route]

\begin{tabular}{|c|c|c|c|c|c|}
\hline $\begin{array}{c}\text { Streamgage } \\
\text { number }\end{array}$ & Streamgage name & $\begin{array}{c}\text { Drainage area } \\
\left(\mathrm{mi}^{2}\right)\end{array}$ & $\begin{array}{l}\text { Latitude } \\
\text { (dd) }\end{array}$ & $\begin{array}{l}\text { Longitude } \\
\text { (dd) }\end{array}$ & $\begin{array}{c}\text { Elevation of gage } \\
\text { (ft) }\end{array}$ \\
\hline 02069700 & South Mayo River near Nettleridge, VA & 85.5 & 36.5710 & -80.1295 & 872 \\
\hline 02070000 & North Mayo River near Spencer, VA & 108 & 36.5682 & -79.9873 & 731 \\
\hline 02071530 & Smith River at Smith Riv Church near Woolwine, VA & 26.3 & 36.7785 & -80.2492 & 1,210 \\
\hline 02072000 & Smith River near Philpott, VA & 215 & 36.7807 & -80.0248 & 804 \\
\hline 02072500 & Smith River at Bassett, VA & 259 & 36.7701 & -80.0009 & 752 \\
\hline 02073000 & Smith River at Martinsville, VA & 379 & 36.6612 & -79.8806 & 657 \\
\hline 02074500 & Sandy River near Danville, VA & 111 & 36.6196 & -79.5042 & 460 \\
\hline 02075045 & Dan River at Stp near Danville, VA & 2,116 & 36.5626 & -79.3697 & 365 \\
\hline 02075500 & Dan River at Paces, VA & 2,587 & 36.6424 & -79.0895 & 322 \\
\hline 02077000 & Banister River at Halifax, VA & 547 & 36.7765 & -78.9158 & 316 \\
\hline 02077500 & Hyco River near Denniston, VA & 288 & 36.5879 & -78.8986 & 315 \\
\hline 02079640 & Allen Creek near Boydton, VA & 53.5 & 36.6796 & -78.3267 & 217 \\
\hline 03164000 & New River near Galax, VA & 1,141 & 36.6473 & -80.9790 & 2,208 \\
\hline 03165000 & Chestnut Creek at Galax, VA & 39.4 & 36.6460 & -80.9192 & 2,344 \\
\hline 03165500 & New River at Ivanhoe, VA & 1,350 & 36.8348 & -80.9526 & 1,942 \\
\hline 03167000 & Reed Creek at Grahams Forge, VA & 258 & 36.9390 & -80.8873 & 1,925 \\
\hline 03168000 & New River at Allisonia, VA & 2,212 & 36.9376 & -80.7456 & 1,848 \\
\hline 03170000 & Little River at Graysontown, VA & 309 & 37.0376 & -80.5567 & 1,816 \\
\hline 03171000 & New River at Radford, VA & 2,767 & 37.1418 & -80.5692 & 1,712 \\
\hline 03173000 & Walker Creek at Bane, VA & 299 & 37.2682 & -80.7095 & 1,666 \\
\hline 03175500 & Wolf Creek near Narrows, VA & 223 & 37.3057 & -80.8498 & 1,584 \\
\hline 03176500 & New River at Glen Lyn, VA & 3,783 & 37.3729 & -80.8606 & 1,490 \\
\hline 03177710 & Bluestone River at Falls Mills, VA & 44.3 & 37.2715 & -81.3048 & 2,310 \\
\hline 03207800 & Levisa Fork at Big Rock, VA & 297 & 37.3537 & -82.1957 & 866 \\
\hline 03208500 & Russell Fork at Haysi, VA & 286 & 37.2071 & -82.2957 & 1,238 \\
\hline 03208950 & Cranes Nest River near Clintwood, VA & 66.5 & 37.1240 & -82.4388 & 1,440 \\
\hline 03209000 & Pound River below Flannagan Dam, near Haysi, VA & 221 & 37.2371 & -82.3432 & 1,200 \\
\hline 03471500 & South Fork Holston River at Riverside, near Chilhowie, VA & 76.6 & 36.7604 & -81.6312 & 2,107 \\
\hline 03473000 & South Fork Holston River near Damascus, VA & 303 & 36.6518 & -81.8440 & 1,792 \\
\hline 03474000 & Middle Fork Holston River at Seven Mile Ford, VA & 132 & 36.8073 & -81.6221 & 1,960 \\
\hline 03475000 & Middle Fork Holston River near Meadowview, VA & 206 & 36.7132 & -81.8187 & 1,820 \\
\hline 03478400 & Beaver Creek at Bristol, VA & 26.9 & 36.6318 & -82.1337 & 1,781 \\
\hline 03488000 & North Fork Holston River near Saltville, VA & 221 & 36.8968 & -81.7462 & 1,704 \\
\hline 03490000 & North Fork Holston River near Gate City, VA & 671 & 36.6087 & -82.5679 & 1,198 \\
\hline 03524000 & Clinch River at Cleveland, VA & 533 & 36.9448 & -82.1549 & 1,925 \\
\hline 03524500 & Guest River at Coeburn, VA & 87.2 & 36.9293 & -82.4563 & 1,926 \\
\hline 03527000 & Clinch River at Speers Ferry, VA & 1,123 & 36.6487 & -82.7504 & 1,196 \\
\hline 03529500 & Powell River at Big Stone Gap, VA & 112 & 36.8690 & -82.7754 & 1,458 \\
\hline 03531500 & Powell River near Jonesville, VA & 319 & 36.6620 & -83.0949 & 1,259 \\
\hline
\end{tabular}


bubble gages with submersible and non-submersible pressure transducers, and non-contact radar and acoustic sensors (Sauer and Turnipseed, 2010). When installed and maintained properly, both stage measurement systems can be used to collect stage data accurate to within 0.01 foot or 0.2 percent of the effective stage, whichever is greater. In general, a bubble gage and transducer may be installed more quickly and for a lower cost than a stilling well, but a bubble gage and transducer may need to be replaced more frequently during the lifetime of the streamgage.

Flow measurements are made to develop ratings at new sites and to document changes to them once established. Routine trips are frequent enough to characterize the stageflow relation for low, medium, and moderately high flows. Extra visits are made to measure floods, which are infrequent and are of particular interest to major national institutional stakeholders. Additionally, the relation between flood stage and flow typically remains stable for years or decades. Water velocity is measured with either a Price-type vertical axis mechanical current meter or a hydroacoustic Doppler velocimeter, a class of instrument that includes Acoustic Doppler Current Profilers. In wadeable streams, either type of meter may be deployed from a wading rod, which is also used to sound depth. At nonwadeable flows, hydroacoustic velocimeters are deployed on a custom-made boat that is towed across the river from a bridge, cableway, or boat, and depth is measured using a sonic sounder incorporated into the meter. If a mechanical meter is used, it is deployed with sounding weights from a cable lowered from a bridge, cableway, or boat, and the depth is read from a dial attached to the cable reel.

The principal field tasks for streamgaging are measuring flow and maintaining stage sensors and related equipment and structures. Some tasks are done about annually, such as differential leveling from gage features to benchmarks to ensure that instruments or bubble gage orifices have remained physically stable and therefore are capable of recording accurate stage data. Other maintenance tasks need to be done more frequently; the necessary frequency varies according to site conditions, such as sediment load and deposition patterns. A routine site visit includes checking the recording gage against a non-recording reference gage, flushing intakes at stilling wells, repairing or replacing any equipment that has malfunctioned, and a control inspection.

Documentation of control inspections provides a record of changes to the control through time. This documentation is critically important for interpreting rating changes. Common changes to controls include scour and fill during rises in flow, growth and death of macrophytes and algae, and accumulation and removal of leaves or large woody debris. Less common changes that may be large in magnitude include those caused by humans or animals placing material on or removing material from the control; some of the largest rating changes at low flow result from dams built by beavers or swimmers. Several of these types of changes are clearly temporary. Changes to a control related to scour and fill may be either short term or long term, and the judgment about how long to expect such a change to remain typically is made in light of previous experience with the site and magnitude of the change.

\section{Flow Data Computation}

Flow data computation is complex and includes several steps that are done manually and involve data interpretation on the part of the hydrographer. Quality assurance of stage data is necessary but usually simple. When it is not simple, the aspects of the stage record that require the most interpretation involve records affected by sediment deposition on intakes or orifices, equipment malfunctions, or errors resulting from the movement of stage sensors as discovered through differential leveling. Stage sensors move rarely, such as during a major flood, but when they do, correcting the record requires extensive work. Equipment is much more reliable than it was historically but might still malfunction at a few sites operated by any specific field office during a year. In contrast, sediment deposition is common and unavoidable in some streams, particularly low-gradient streams where the streambed includes substantial amounts of clay, silt, and sand. Correcting stage records affected by deposition requires extensive interpretation.

Development and maintenance of the rating curve is fully interpretive. Rating curves are empirical, and curve fitting is done graphically. Most streamgages have simple controls, for which stage is a simple function of flow; however, for some streamgages, control is a function of rate of variable backwater, tide, or some other characteristic. At streamgages with simple controls, the rating curve is a graphical depiction of the stage-flow relation for a specific hydraulic control, typically a natural feature such as a channel constriction, change in streambed slope, or the aggregate characteristics of channel slope and roughness. Where the feature in question is a weir or a bedrock ledge, or is formed from bedrock and large boulders, the control typically changes infrequently, and office work related to the rating may be straightforward. Where the feature is formed from small boulders, cobbles, sand, fine materials, or a mixture of substrates, the control may change frequently and require extensive office work to analyze the stage-flow relation.

Each measurement is evaluated carefully, first in the field, where it is initially plotted on the rating curve, and later in light of successive measurements. Measurements that plot off the curve by more than the expected percentage require a new rating, a shift, or an explanation for the error of the measurement. A shift is a temporary rating curve, which is typically a modification of the base rating curve for part of its range in stage. The decision on whether to respond to a change to a control by using a shift or a new rating involves determining when the control changed, the nature of the change, and how long the change lasted or is expected to last. A new base rating is essentially impossible to develop on the basis of a single measurement, even in cases such as obvious large changes to 
controls following major floods. However, a rating may be developed as the necessary measurements become available, and when complete, the rating can be backdated to the time of the actual change to the control. In this case, provisional data displayed on the web will be processed using a series of shifts, but the final "approved data" will be processed using the final rating. Often, the provisional data are corrected during review. The office procedures the USGS has historically used for computing flow data include several steps of review, any of which may result in corrections. Substantial changes to initial data are common, including to provisional data that previously have been posted online and used by the public.

The development of shifts and ratings are discussed in an internal document, the station analysis, which is prepared for each streamgage every year and archived permanently. The station analysis comprehensively details changes in stage datums; the adjustment and correction of stage data, including corrections applied as a result of documented sensor drift; the nature and condition of the channel controls, including changes in the location, shape, composition, and roughness of the control; the shape and historical stability of the resulting ratings; the number, quality, and range of the flow measurements and their relation to the rating in terms of coverage of stage and time; and the detection of shifts and the adjustment of them to account for control changes. The station analysis also documents efforts to compare the resulting flow records to flow records collected for other locations on the same or nearby streams, as well as to other hydrologic or meteorological information (such as rainfall or temperature records). Lastly, the station analysis documents the subjective quality assessment of the hydrographer who computes the record and prepares the station analysis.

The station analysis and all of the elements of the flow record are reviewed by a colleague hydrographer, the office chief or supervisor, and often one or more hydrographers from another office or other technical specialists. The Virginia Water Science Center of the USGS also runs various computer scripts that scan the record for outliers and inconsistencies, the rating and shifts for unusual or hydraulically unsound shapes and changes. All of these steps contribute to the production of a reliable and defensible "approved" flow record, but few of the steps were applied prior to the automatic posting of "provisional" record.

To help guide individual hydrographers and to instill more consistency in local practices, the USGS requires each Water Science Center to develop a single, comprehensive quality-assurance plan for surface-water activities within the center, including its streamgaging operations. The document provides guidance on the need for measurements, guidance on parameters for measurement frequency and range, and instructions about which control, measurement, and instrumentation factors to consider when conducting fieldwork or processing records, including rating development and shift applications. The document also establishes requirements for training of hydrographers and the review of their work.
The quality of the flow record is assessed and recorded in Water Year Summaries, which have replaced Site Data Sheets, which had previously replaced Annual Water-Data Reports (U.S. Geological Survey, 2016a). The assessment reflects the judgment of hydrographers from the station analysis. These qualitative assessments are among the information that USGS publishes to the Water Year Summaries, but the assessments are not captured in the National Water Information System or related electronic databases. Therefore, the assessments are difficult to incorporate in quantification studies.

Although the USGS has made standardizing record processing a priority, the processing has retained elements of a craft. Individual judgment is part of the process. Different analysts may achieve the same results using slightly different methods. For the purposes of this study, these differences matter because, by design, criteria for developing a shift overlap with criteria for developing a new rating. A shift is to be applied when in the hydrographer's judgment the rating change is temporary, in contrast to a new rating, which is to be developed when a change to a control is permanent (or has reached equilibrium). In practice, hydrographers make judgments differently about whether a measured change is temporary or permanent. Some will develop a new rating as soon as enough measurements have been made to define the change, whereas others will apply a shift for several years, adjusting it as needed, to see whether the control changes back. Some hydrographers might apply and adjust shifts for years or even decades through a series of bed changes without changing the base rating. These analytical differences make little if any difference to the published flow data but complicate efforts to use the number and frequency of rating changes to compare stability among sites and through time.

The USGS has implemented "continuous records processing," a procedure in which data are processed immediately upon the return of hydrographers to the office from a field trip. In 2014, the USGS Office of Surface Water (OSW) issued Technical Memorandum 2014-08, which calls for all USGS Water Science Centers to correct time-series stage and flow data and enter flow measurements into the National Water Information System Web (NWIS-Web) database within 2 business days of a field measurement. Computed real-time data on NWIS-Web that do not match the flow measurement within its rated accuracy are to be corrected or removed from public display (Robert Mason, U.S. Geological Survey, written commun., July 14, 2014, https://hydroacoustics.usgs.gov/memos/ OSW2014-08.pdf). Even after continuous records processing has been fully implemented, however, uncertainty will remain as to the accuracy of provisional flow data. The accuracy of provisional flow data depends on several factors, including quality and promptness of field and office work, the quality of the stage record, and the stability of the rating.

Hydrographers are forced to make judgments about the timing of rating changes and shifts. When the change in rating can be associated plausibly with a distinct rise in flow, most hydrographers attempt to start the new rating to coincide with 
peak flow. When this is not practical, ratings will begin on convenient but arbitrary dates. Some hydrographers prefer to change base ratings relatively frequently and attempt to associate the start time with a hydrologic event. Others will change base ratings at convenient times and use shifts before and after the base-rating change to make a smooth transition. A great deal of care is taken to look for a plausible event for the beginning of shifts, regardless of the approach used for the timing for base-rating changes. A scour shift typically begins while flow rises, and a fill shift begins while flow recedes. This practice is based on an extensive body of empirical evidence from flow measurements made across rises in flow at many streamgages (Rantz and others, 1982).

Monthly field measurements were standard from the beginning of continuously recorded stage until telemetry or satellite data transmissions became widely used in the 1980s. At that time, adoption of the new technology, which enabled hydrographers to know whether stage was being recorded, coincided with increased budgetary pressures. The USGS did a series of studies in most states during the 1980s intended to optimize network design. The studies were modeled after work done in the Lower Colorado River Basin (U.S. Geological Survey, 1998; Moss and Gilroy, 1980). Primary considerations were cost effectiveness, minimizing lost record, and characterizing rating changes. An algorithm was developed that allowed the tradeoffs between various options to be quantified as their contributions to the standard error of mean annual flow. This algorithm was applied on a state-by-state basis, and the results were aggregated nationally. This led to the determination that for most states, the optimal tradeoff between cost and accuracy for a typical streamgage was a frequency of 6-8 site visits per year. More measurements are made for streamgages where beds are extremely unstable, such as those with sand beds, or at locations where consequences of error are great, such as the Colorado River at the United States-Mexico border (Wahl and others, 1995; Anning, 2001).

\section{Ratings and Shifts for Streamgages in Virginia through 2013}

Availability of ratings and shifts varied by streamgage, largely because archival methods varied by field office and immediate operational needs (tables 2 and 3, at end of report). Although mean daily flow values have been computed in NWIS since the adoption of the database, different Water Science Centers and field offices have archived different amounts of ancillary data, such as ratings and shifts, throughout the 1980s, 1990s, and into the 2000s. Archiving of all shifts and ratings did not become universal and mandatory until the 2002 water year. Rating availability exceeded shift availability.

During the study period, 643 base ratings were available in the database (table 4, at end of report). In this report, "the database" refers to the Virginia node of the NWIS. Unless another state is specified, references to NWIS also refer to the Virginia node.

Base ratings are each stored as a separate file, and all files include explanatory comments. Therefore, base ratings are straightforward to inventory. Shifts are stored in a more complicated fashion than ratings. All shifts for each site are stored together in a table. Each shift is stored as multiple entries with varying numbers of fields per shift and varying amounts of metadata, depending on when the shift was created and the nature of the shift. Because all shifts were associated with beginning dates and times, the simplest way to inventory them was to filter them by time.

Many of the shift entries, however, represent the same shift entered for multiple beginning times, and there is no straightforward way to identify and group them. The number of points needed to define a shift varies. The magnitude of an individual shift frequently varies during the course of the shift. More than one shift can be in effect simultaneously at different parts of the rating. Comments for some entries indicate that the shift is continued unchanged when the record is being updated. Some shift entries exist solely for transitions across the water year (from September 30 to October 1). Some hydrographers also follow a practice of creating, entering, and implementing shifts of zero value in order to compute flow values directly from the base rating, instead of ending the previous shift. Had the entire set of shifts included comments, repeated shifts probably could have been reliably identified. With incomplete explanatory information, however, retrospectively relating shifts with hydrologic events in bulk can be done only imprecisely.

October 1, at the beginning of the water year, was the most common date for implementing a rating; 161 ratings began on October 1 of one year or another (table 5). Another 157 ratings were put into effect on the date of a measurement. (Twice, a rating started on an October 1 when a measurement was made.) Most of these were probably convenient dates to convert a shift to a new rating, although 46 of the measurements were made on days with peaks, either floods or highflow pulses, or flow events smaller than floods when flow rose but stayed within the channel. Sixty-two ratings were already in effect on October 1, 1990. Another two ratings were put in effect on a date with no approved daily flow value; these were dates before the associated streamgage was activated or reactivated. Of beginning dates with approved daily flow values, 199 came on peaks, either floods or high-flow pulses, and another 23 came on days when flow exceeded the 10-percent duration (D10). The remaining 217 ratings began on dates when no measurement was made, flow was less than the D10, and no peak was evident in the daily flow record.

About 23,000 shifts with unique beginning times were available for water years 1991-2013 (table 3). This set includes shifts that began before water year 1991 or before a streamgage was fully active, but the shifts were still in effect when the flow data used in this study were collected. Of the available shifts, 6,273 began on days when more than one 
Table 5. Selected characteristics of daily flows on days that base ratings began at streamgages in Virginia, water years 1991-2013.

$[<$, less than; $>$, greater than; D10, flow exceeded or equaled on 10 percent of days; italicized entry is a subcategory of the preceding category; Categories are not mutually exclusive, individual ratings may belong to more than one category, and columns are not intended to add up to the total]

\begin{tabular}{lcc}
\hline \multicolumn{1}{c}{ Category } & \multicolumn{2}{c}{ Days shifts began } \\
\cline { 2 - 3 } & Number & Percentage \\
\hline Total & 643 & 100 \\
Began on a peak, including high-flow pulses & 199 & 31 \\
In effect on October 1, 1990 & 62 & 10 \\
Put in effect during the study period, but before daily value record began & 2 & 0 \\
Began October 1, total & 225 & 35 \\
$\quad$ - No peak on 9/30 or 10/1 & 223 & 35 \\
Began on a day with flow $>$ D10, on rise or recession but not peak & 23 & 4 \\
Began on any day when a measurement was made & 157 & 24 \\
$\quad-$ Flow $>$ D10 & 24 & 4 \\
$\quad$ On a peak & 46 & 7 \\
$\quad$ Not on a peak, and flow $<$ D10 & 105 & 16 \\
Other & 217 & 34 \\
\hline
\end{tabular}

shift began. The maximum number of shift entries, 32, came on a day when a measurement was made and a beaver dam subsequently was removed from a control over a period of several hours (October 4, 2005, at 01671100, Little River near Doswell, VA).

Setting aside the multiple shifts made on the same day at the same site, there were records for days with 16,853 unique shifts beginning at streamgages during water years 1991-2013 (table 6). Forty-one percent of shifts $(6,842)$ began on days when the daily flow record showed a peak. These peaks included floods and high-flow pulses. For this analysis, a fairly liberal definition of a high-flow pulse was used: flow on a day that was greater than flow on either of the two preceding days or the subsequent day. Additionally, the days following rises in flow were identified and tallied separately, and generally represent days when a peak was receding; 7 percent of days when shifts began $(1,144)$ were the days following peaks.

Because shifts were developed using unit flow values, not daily flow values, flagging flow events using daily values can result in some errors related to time resolution. For instance, comments associated with shifts indicated that many began on a rise that peaked during the evening or night when the daily value for the following date was greater than the daily value on the date of the peak. More than a thousand shifts began on days of high flow although not on the peak. Seven percent of shifts began on such days when flow exceeded the D10 $(1,135)$, and about 1 percent of those $(168)$ began on days when flow exceeded the 1-percent duration flow (D1). These shifts were not necessarily intended to begin on the peak. Scour shifts often begin at the start of the rise and are in full effect at the peak, whereas fill shifts begin on the peak and are prorated through the recession.

Not all shift beginnings were clearly associated with an event. October 1, the first day of the water year, was ordinarily a convenient but arbitrary day to begin a shift. It was a common begin date for a set of shifts filtered to one per day; 5 percent (797) of the 16,853 shifts began on October 1 (table 6).

Many shifts began the day that a measurement and streamgage inspection was made; 34 percent $(5,681)$ of shifts began on these days. However, many of the measurements were made on days of peaks and high flows; 602 of the measurements were made on days when flow exceeded the D10, and 1,365 began either on the day of a peak or the day following a peak. There was overlap between days of peaks and days of high flows, but the upshot is that 24 percent of shifts began on days when a measurement was made, not on a peak or the day after a peak, and when flow was less than the D10. Shifts begun on days of medium or low flow and without peaks were not 
Table 6. Selected characteristics of daily flows on days that shifts began at streamgages in Virginia, water years 1991-2013.

$[<$, less than; $>$, greater than; D1, flow exceeded or equalled on 1 percent of days; D10, flow exceeded or equalled on 10 percent of days; italicized entry is a subcategory of the preceding category; Categories are not mutually exclusive, individual shifts may belong to more than one category, and columns are not intended to add up to the total]

\begin{tabular}{lrc}
\hline \multirow{2}{*}{ Category } & \multicolumn{2}{c}{ Days shifts began } \\
\cline { 2 - 3 } & Number & Percentage \\
\hline Total & 16,853 & 100 \\
Began on a peak, including high-flow pulses & 6,842 & 41 \\
Began the day after a peak & 1,144 & 7 \\
Began October 1, total & 797 & 5 \\
$\quad$ - No peak on 9/30 or 10/1 & 572 & 3 \\
Began on a day with flow $>$ D1, on rise or recession but not peak & 168 & 1 \\
Began on a day with flow $<$ D1 but $>$ D10, on rise or recession but not peak & 967 & 6 \\
Began on any day when a measurement was made & 5,681 & 34 \\
$\quad$ - Flow $>$ D10 & 602 & 4 \\
- On a peak & 831 & 5 \\
- Day after a peak & 534 & 3 \\
- Not on a peak, and flow $<$ D10 & 4,024 & 24 \\
Other & 3,136 & 19 \\
\hline
\end{tabular}

necessarily arbitrarily associated with the measurement date. Controls are sometimes cleaned during streamgage inspections, which in turn results in one or more shift entries showing a return to the base rating. In the case of scour or fill shifts, it would be common (if not universal) practice to make a shift entry the day of the measurement for an existing shift, even when the shift was carried without change.

Frequently, shifts began at multiple streamgages on the same date, which also demonstrates the effort made to associate shifts with hydrologic events (table 7). The maximum number of streamgages with shifts beginning on the same date was 87 , on October 1, 2010, a day when, in addition to being the beginning of the water year, 52 streamgages had a high-flow pulse, 38 had flow between the D10 and D1, and 9 had flow exceeding the D1. On 41 days, shifts began at 30 or more streamgages. Of those days, 11 were October 1 of one year or another, including several years when flow was high at several streamgages on October 1. The greatest number of streamgages with shifts beginning on a different date, 63 , came on January 31, 2013.

Determining the precise number of days on which shifts are in effect was impractical because of the complexity of the shift dataset in combination with an incomplete set of explanatory comments. The shift dataset includes shifts of 0 feet that were created and put in place for the convenience of hydrographers at a particular site, some of which include comments to the effect that the rating was used directly for the designated period. Additionally, more than one shift could be in effect at different points on the rating at the same time. Unraveling the shift process might have been done with more complete electronic documentation.

Timing of record working changed markedly during 1991-2013 (figs. 2 and 3). The relation of the start dates of shifts to dates of the final modification gives an approximate idea of when the record was worked and represents the best means available to estimate, in general, when the various shifted ratings used in this study were likely to have been developed and implemented.

During the early 1990s, record working was done primarily on an annual basis during a distinct office season, winter and spring (fig. 2). Few records were worked during the summer and fall when streamgage maintenance was done. From 1991 through 2001, the median number of days between the start date of the shift, the first date of data for which it was intended to modify, and the date it was created in the office by a hydrographer, fluctuated between about 240 and about 300 days. The 75th percentile of days between start date and creation date of shifts was more than 365 for every year during that period. Beginning in 2002, in recognition of the growing importance of near-real-time flow data to data 
Table 7. Dates on which shifts began at 30 or more streamgages, and flow characteristics for that day at the streamgage in question in Virginia, water years 1991-2013.

$[<$, less than; >, greater than; D10, 10-percent flow equalled or exceeded 10 percent of the time; D1, flow equalled or exceeded 1 percent of the time; DV, daily value or mean daily flow]

\begin{tabular}{|c|c|c|c|c|c|c|}
\hline \multirow[b]{2}{*}{ Date } & \multicolumn{5}{|c|}{ Flow characteristic on the given date } & \multirow{2}{*}{$\begin{array}{l}\text { Total number } \\
\text { of streamgages } \\
\text { for date }\end{array}$} \\
\hline & $<\mathrm{D} 10$ & $D 10<D V<D 1$ & $>$ D1 & $\begin{array}{c}\text { Peak or } \\
\text { high-flow pulse }\end{array}$ & $\begin{array}{c}\text { One day } \\
\text { after peak }\end{array}$ & \\
\hline $10 / 1 / 2010$ & 40 & 38 & 9 & 52 & 2 & 87 \\
\hline $10 / 1 / 2007$ & 83 & 0 & 0 & 2 & 6 & 83 \\
\hline $1 / 31 / 2013$ & 22 & 9 & 32 & 25 & 2 & 63 \\
\hline $10 / 1 / 2006$ & 58 & 1 & 0 & 11 & 32 & 59 \\
\hline $10 / 1 / 2009$ & 58 & 0 & 0 & 0 & 2 & 58 \\
\hline $6 / 28 / 2006$ & 4 & 23 & 30 & 45 & 2 & 57 \\
\hline $10 / 27 / 2007$ & 33 & 18 & 2 & 34 & 2 & 53 \\
\hline $10 / 1 / 2002$ & 53 & 0 & 0 & 0 & 1 & 53 \\
\hline $10 / 1 / 2008$ & 49 & 0 & 0 & 2 & 5 & 49 \\
\hline $11 / 20 / 2003$ & 1 & 17 & 30 & 33 & 0 & 48 \\
\hline 9/19/2012 & 32 & 15 & 0 & 32 & 1 & 47 \\
\hline $11 / 30 / 2005$ & 9 & 19 & 19 & 29 & 0 & 47 \\
\hline $12 / 8 / 2011$ & 3 & 20 & 23 & 28 & 0 & 46 \\
\hline $5 / 8 / 2013$ & 9 & 16 & 20 & 25 & 1 & 45 \\
\hline $12 / 1 / 2010$ & 8 & 22 & 14 & 38 & 0 & 44 \\
\hline $7 / 8 / 2005$ & 15 & 14 & 15 & 35 & 0 & 44 \\
\hline $2 / 23 / 2003$ & 0 & 2 & 42 & 30 & 1 & 44 \\
\hline $12 / 12 / 2008$ & 17 & 21 & 3 & 25 & 0 & 41 \\
\hline 5/7/2013 & 20 & 11 & 7 & 9 & 0 & 38 \\
\hline 10/1/1997 & 38 & 0 & 0 & 6 & 16 & 38 \\
\hline $1 / 15 / 2013$ & 35 & 2 & 0 & 0 & 0 & 37 \\
\hline $9 / 27 / 2009$ & 28 & 7 & 1 & 24 & 0 & 36 \\
\hline $10 / 30 / 2012$ & 10 & 5 & 20 & 25 & 0 & 35 \\
\hline $10 / 1 / 2001$ & 35 & 0 & 0 & 2 & 2 & 35 \\
\hline $4 / 23 / 2006$ & 11 & 20 & 3 & 22 & 0 & 34 \\
\hline $4 / 16 / 2007$ & 1 & 20 & 13 & 27 & 0 & 34 \\
\hline $1 / 16 / 2013$ & 16 & 10 & 7 & 14 & 2 & 33 \\
\hline $12 / 2 / 2010$ & 5 & 24 & 4 & 24 & 0 & 33 \\
\hline $10 / 9 / 2005$ & 8 & 9 & 16 & 30 & 0 & 33 \\
\hline $2 / 7 / 2004$ & 2 & 20 & 11 & 18 & 0 & 33 \\
\hline $12 / 27 / 2012$ & 11 & 18 & 2 & 23 & 0 & 31 \\
\hline $3 / 29 / 2005$ & 0 & 16 & 15 & 19 & 2 & 31 \\
\hline $9 / 29 / 2004$ & 0 & 0 & 31 & 29 & 0 & 31 \\
\hline $10 / 1 / 2004$ & 9 & 20 & 2 & 3 & 13 & 31 \\
\hline $4 / 14 / 2004$ & 0 & 22 & 9 & 22 & 0 & 31 \\
\hline $10 / 15 / 2001$ & 30 & 1 & 0 & 17 & 0 & 31 \\
\hline $10 / 1 / 1994$ & 31 & 0 & 0 & 1 & 0 & 31 \\
\hline $3 / 1 / 2012$ & 7 & 18 & 5 & 20 & 0 & 30 \\
\hline $10 / 1 / 2003$ & 27 & 3 & 0 & 0 & 1 & 30 \\
\hline $11 / 13 / 2002$ & 3 & 26 & 1 & 25 & 1 & 30 \\
\hline 10/1/1999 & 14 & 7 & 9 & 22 & 2 & 30 \\
\hline Subtotals & 835 & 494 & 395 & 828 & 96 & 1,724 \\
\hline $\begin{array}{l}\text { Totals for all dates } \\
\text { at all sites }\end{array}$ & 11,085 & 3,691 & 2,002 & 6,842 & 1,144 & 16,853 \\
\hline
\end{tabular}


users, a greater effort was made to work records continu-

ously. The median delay between the start date of a shift and its final modification decreased by about 4 months from 2001 to 2002 (fig. 3). Even so, many records required review and revision after more data had been collected, and one-quarter or more of shifts had delays of 3 months or more through 2013. During water years 1991-2013, one-half of the shifts had a delay between start date and final modification of about 60 days only in 2012 and 2013 . Because 60 days is close to the 8 -week interval between routine streamgage visits, these 2 years represent the first time when the expanded shifted rating saved in the database was more likely than not to be the one used to generate provisional data served to the internet. Even in those years, though, more than one-quarter of shifts were modified 90 days or more after the shift's beginning date. Because defining a shift that affects the stage-flow relation through a range of flows requires multiple measurements made during multiple trips, there will be limits to how quickly shifts can be completed, even with the most diligent efforts possible to work records continuously.

Vertical and horizontal banding is evident in the plot of shift start dates relative to final modification dates (fig. 2).

Horizontal bands represent days when large numbers of shifts were put into effect on the same day; these might be days when many shifts were approved but are artifacts of data computation. Vertical bands are more interesting. Because they represent days when many shifts began, vertical bands signify the days when hydrographers identified a hydrologic event likely to have altered the control and caused a shift at multiple streamgages. Vertical gaps represent periods when hydrographers judged that no events took place at any streamgages that changed controls and required a shift.

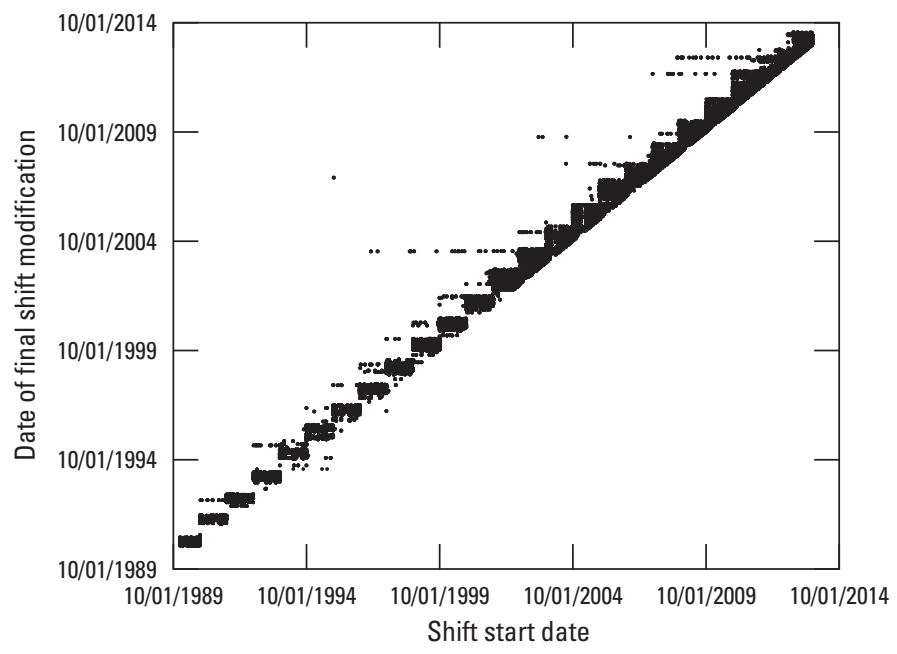

Figure 2. Relation between start dates of shifts and dates of final modification of shifts at streamgages in Virginia, water years 1991-2013. 


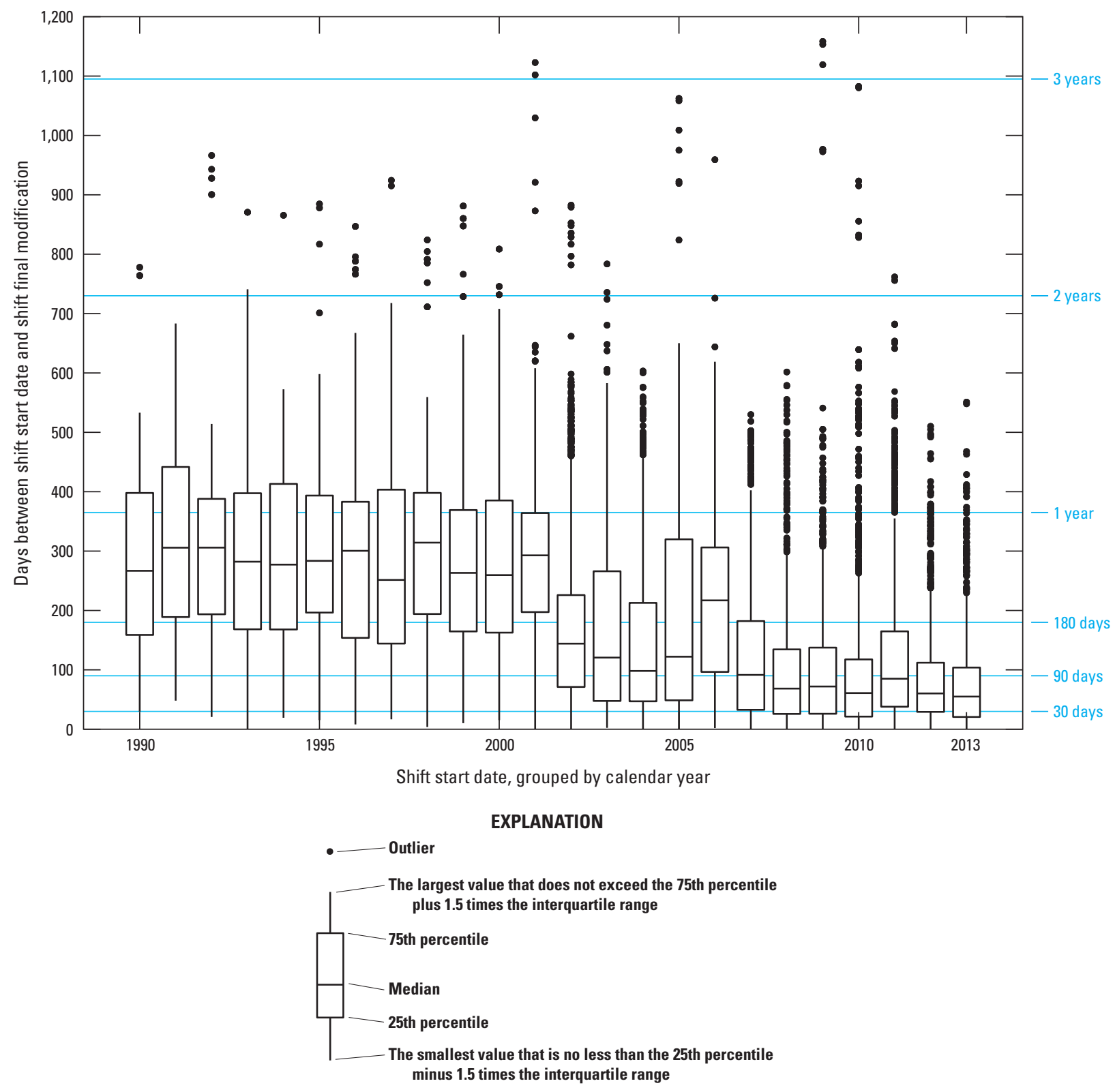

Figure 3. Number of days between start and final modification of shifts at streamgages in Virginia, 1990-2013. 


\section{Patterns in the Stability of Stage-Flow Relations}

Ratings change through time as hydraulic controls change. Minor changes are common and are the principal reason for repeated flow measurements made at a streamgage. Major changes are caused by disruptive events, such as major floods; human activities, such as channel reconfiguration or bridge construction that change streambeds and banks; or even deliberate events such as moving the streamgage or building or removing a weir. Some disruptive events are random. Some may be nonrandom but difficult to anticipate or avoid when streamgage locations are selected.

Patterns of streamgage ratings through time may be thought of as punctuated equilibria. Disruptive events and resulting major changes are relatively rare. Streamgage ratings commonly remain at equilibrium for years or decades between the disruptive events. The length of periods of equilibrium, and routine departures from them, are of primary interest in this discussion of rating stability and the manner in which it relates to the reliability of streamgages during routine periods.

This analysis was done in an iterative manner. The following sections discuss major parts of this analysis. Flow measurements were plotted and curves were fitted through them. Residuals from the curves (the difference between the observed and predicted value of the dependent variable) were plotted as a time series. Patterns in the time series were compared to patterns in the scatter plots, and major changes were noted. These major changes were used to define "rating families" or series of ratings and shifted ratings representing periods of equilibrium. Curves were then fitted through the rating families, and time series of the residuals were used to check their identification and refine their designations.

Ratings and shifts are depictions of the stage-flow relation and are developed from flow measurements. Much of the analysis in this section was done using flow measurements. Flow measurements are the only available method to quantify the shiftiness of controls, although certain types of shifts can be developed in the absence of flow measurements. Leaf shifts, for instance, are needed for streams flowing through deciduous forests when autumn leaves fall from the trees into the stream and accumulate into a leaf mat on a streamgage control. These leaf mats typically remain in place until a highor moderately high-flow episode washes them off the control. They can be detected on real-time hydrographs in the absence of flow measurements, as a gradual, multiday rise in stage in the absence of precipitation, in Virginia, during October or November. Leaf mats form during a season when flows are at or near annual lows.

In an iterative process, a LOESS curve was fit through all available flow measurements for all the streamgages in Virginia's real-time network as of September 30, 2013, with at least 20 flow measurements with positive flow values. This curve served as an average long-term rating. For each measurement with a positive flow value, residuals from the curve were calculated. Measurements with negative or zero flow values were not considered as part of this analysis because these values do not exhibit consistent stage-flow relations.

A set of plots was developed showing three plots for each streamgage: (1) gage height and flow for all the measurements and the LOESS curve, (2) the residuals plotted by date, and (3) the residuals plotted by Julian date (appendix 1). Curves were fit and plotted using R, ggplot2, and plyr (R Core Team, 2014; Wickham, 2009; Wickham, 2011). Residuals by date were used to explore long-term trends, and residuals by Julian date were used to explore seasonal trends. Printouts of the plots grouped by major river basin or by field office assignment were taken to the three streamgaging field offices active in Virginia: the USGS field offices in Richmond and Marion and the VDEQ field office in Charlottesville. Hydrographers were interviewed about the streamgages with which they were familiar, and notes and sketches were made on the printouts to describe the rating characteristics, measurement quality, streamgage history, and other factors that the hydrographers considered important about the streamgages. The interview information was compiled and merged with descriptive information available from USGS databases (table 8, available online). These plots and statistics were also used to identify and explain major outliers.

\section{Development of Long-Term Average Ratings}

To evaluate long-term stage-flow relations, curves were fitted through points representing all available flow measurements. Different curves were compared. Periods when the relation changed little were determined, and curves were then fitted through points representing flow measurements from these periods.

\section{Comparison of Smoothing Curves}

The LOESS curves that initially were fitted through the measurements fitted poorly and resulted in time-series plots that in some cases were dominated by obvious artifacts of fitting. Different smoothers were then compared to achieve a better fit (fig. 4): (1) linear regression in logarithmic space, (2) Gaussian LOESS with span $=0.5$, (3) symmetric LOESS with span $=0.5$, (4) symmetric LOESS with span $=0.75$, (5) symmetric LOESS with span $=0.25$, and (6) generalized additive model (GAM).This comparison was done for all rating families in the study, although a single representative site, 01634000 , North Fork Shenandoah River at Strasburg, was chosen to illustrate the differences in smoothers (fig. 3). In general, small changes in span made small differences to the pattern and fit of the curves, and the settings used in these plots were broadly representative of ranges of span. The differences between the two families of LOESS curves were not great. The "symmetric" family tended to fit these data slightly better than the "Gaussian" family, but in general, both families had many of the same weaknesses. 

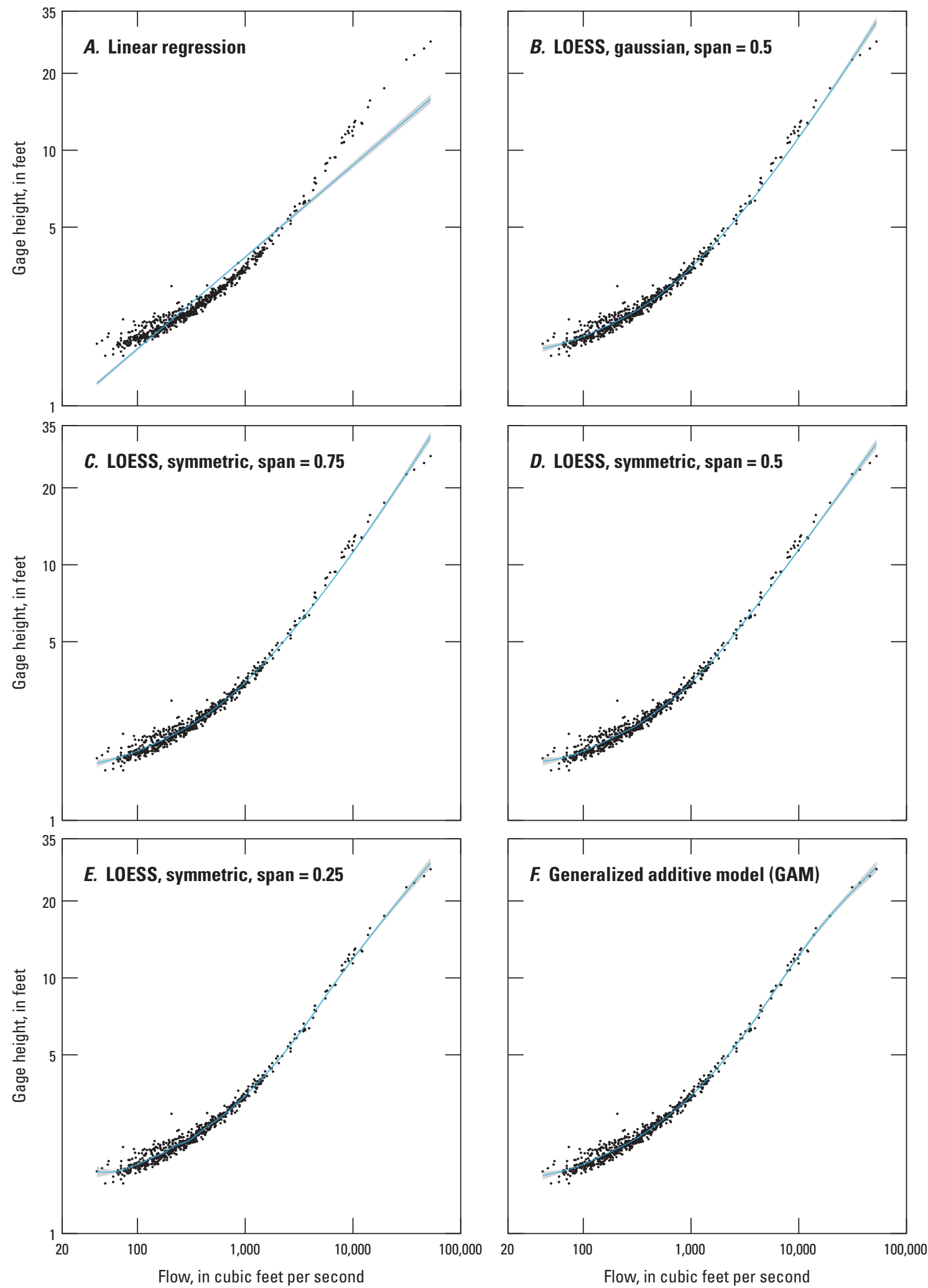

Figure 4. Rating curves for stage-flow relations for streamgage 01634000, North Fork Shenandoah River at Strasburg, VA, with six smoothers applied: $A$, linear regression, $B$, Gaussian LOESS, $C$, LOESS, symmetric $0.75, D$, LOESS symmetric $0.5, E$, LOESS, symmetric 0.25 , and $F$, generalized additive model. Shading represents 99-percent confidence interval. 
The span of a LOESS curve is a measure of how localized the curve is. A small value of span represents a highly localized curve, which uses relatively few of the points in the plot and only those closest to that section of the data. Values of span less than 1 correspond to the proportion of points that is used for computing the regression. At a span of 1 , all the points in the plot are used, although they are weighted. With an infinite span, all points are used without weights so that it is functionally a linear regression. A GAM is a generalized linear model in which the linear predictor is given by a user-specified sum of smooth functions of the covariates plus a conventional parametric component of the linear predictor; models are fitted by penalized likelihood maximization, in which the model likelihood is modified by the addition of a penalty for each smooth function (Wood, 2011, 2014).

The fit of the LOESS curves to these data varies, but many are poor. Fit through the high measurements was systematically poor with, as an example, the various LOESS fits for streamgage 01634000, North Fork Shenandoah River at Strasburg, VA, showing typical problems (fig. 4). Actual ratings are carefully drawn (or fitted) through the highest measurements, those made when stage is controlled by a channel feature instead of a bed feature. Frequently, LOESS curves missed these points, and these points had large residuals. Although rating families could be separated using the residuals from these curves, these residuals were problematic for further statistical analysis. In contrast, the GAM curve fitted the high measurements neatly.

In some cases, decreasing the span of the LOESS curve improved the fit of the high end, but this often came at the expense of causing the fit through the bulk of points to be eccentric or erratic. Residuals from these curves plotted against date were challenging to interpret because of the prevalence of artifacts.

This pattern is general, not universal. A substantial number of the GAM curves have a worse fit through the data than one or several of the LOESS curves, even at the high end of the plot. A tally was made of which of the five types of smoothers used in the rating family plots had the best fit. Criteria for best fit include, in order of priority, splitting the difference cleanly when plots appeared to show multiple populations; handling changes in data density, particularly handling changes in the pattern of high measurements likely to represent the break onto the flood plain; insensitivity to small groups of outliers near a dense cloud of points; and smoothness of the curve.

The GAM curves have the best fit for 214 of the 331 sets of plots; this comparison included 30 rating families from partial-record and crest-stage sites that were ultimately not included in this report. In cases where the fit was not appreciably better for one type of curve than for another, the curve was counted with the family that less frequently had the best fit. For many of the sets of plots, several of the smoothers fitted well; for many of them, none fitted particularly well. The
GAM curves seemed to excel at dealing with changes in data density. Often, the LOESS curves appeared to be affected by a dense cloud of data from a different range of values. Although no attempt was made to quantify which of the smoothers had the worst fit, the GAM plots generally had poor fits only if all the curves had poor fits. In contrast, LOESS curves with low span values $(0.25$ and 0.5$)$ in some cases showed the best fit (40 and 20 times, respectively) but often fitted the data erratically and would have produced residuals that would have been difficult to interpret.

\section{Classification of Rating Families}

Rating families were classified graphically in an iterative process. Plots were developed that included points of all the flow measurements that were stored in NWIS for each streamgage active in the real-time network as of November 2013. Measurements with negative or zero flow values were removed from the dataset. Negative flows were clear indicators that streamgages did not have a simple relation between stage and flow. Observations of zero flow, similarly, could not be conclusively associated with their corresponding gage height in a meaningful way because, when the gage height of zero flow for a particular cross section is reached, stage could continue to drop. Once these measurements were removed from the local database, all streamgages with 20 or more measurements were retained for analysis.

Curves were fitted through plots of gage height and flow. An initial series of plots was developed with a curve fit through all the points for each site, and a time series of residuals from these curves was plotted alongside the first plot (fig. 5; appendix 1). This process produced many artifacts and erratic patterns in the time series, but major changes could be identified. The gage height-flow plots were examined for clustering, but to lead to a classification as a rating family, a cluster had to correspond to a change in time that was evident in the time series plot. Types of changes in the time series plots used to classify rating families were, in order of priority, (1) abrupt steps upward or downward, (2) sloped transitions between flat steps, (3) major increases or decreases in variability, and (4) breaks in record greater than 2 years coinciding with differences, even ambiguous differences, in the appearance of plots.

The major changes identified in the initial set of plots were discussed in the hydrographer interviews. Notes from these interviews, in combination with station records from the Site Information Management System (SIMS), field observations recorded on measurement forms, and in some cases, office records contemporaneous with the rating changes were used to explain the rating changes.

Once major changes had been identified and confirmed, measurements were designated as belonging to rating families. Both gage height and flow were $\log _{10}$ transformed. A new series of curves was fitted through the data, by major rating 

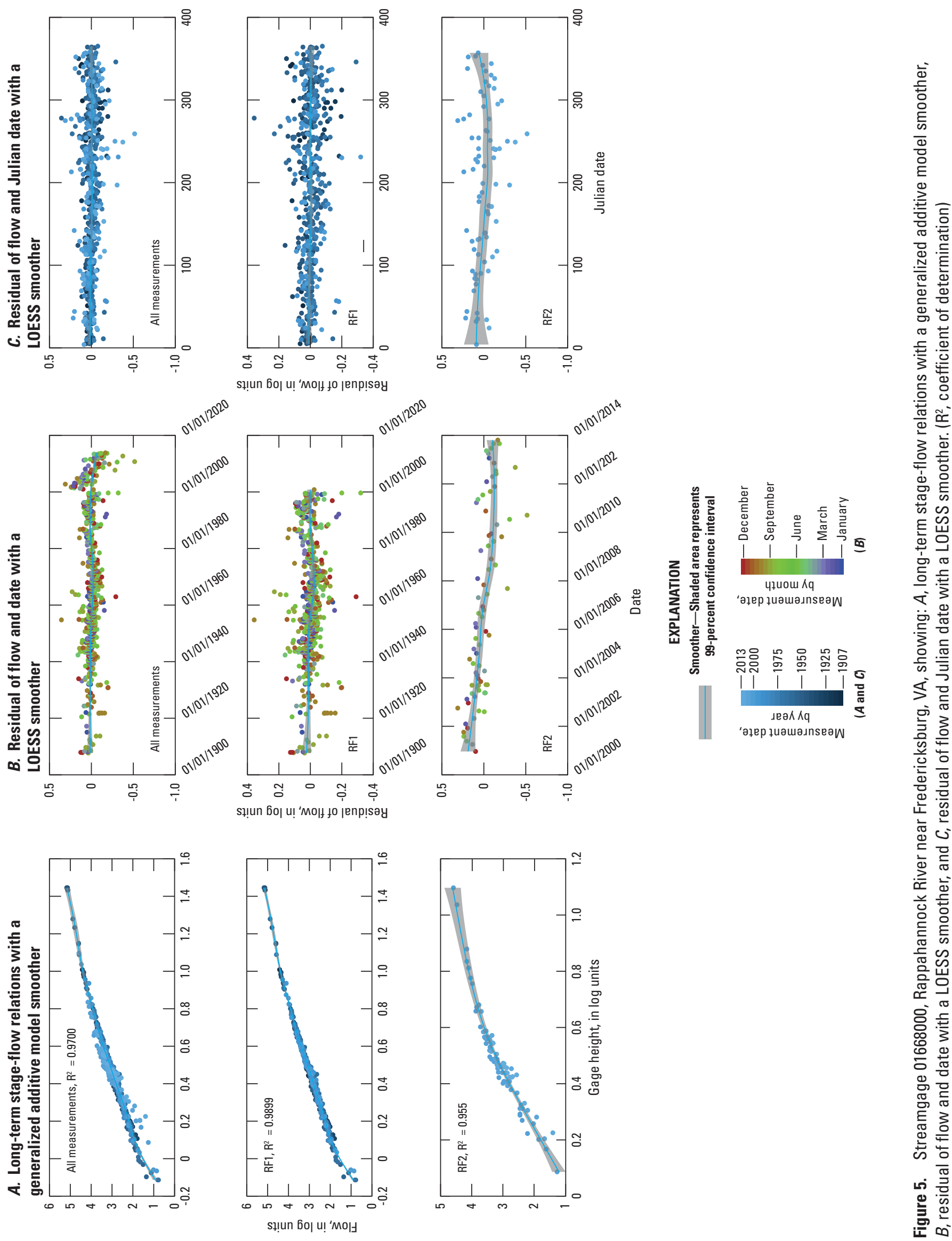
family, and residuals again were captured and plotted as a time series. Rating family classifications were checked graphically, and further subdivisions became evident at this time. Rating family designations in the database were updated, and a set of plots was developed that displayed, by site, a complete time series of residuals from the rating family curves. Transitions between rating families were checked and where necessary corrected, but no new rating families were designated in this iteration. These plots are included in Appendix 1.

Rating families were identified from the measurement plots. If clusters in the gage height flow plots could be related to major step trends or changes in variability in the residual time series, these sets of measurements were considered candidates for a rating family. Attempts were made to relate the events that changed the control to the observed differences in the plots. At the 174 sites, 301 rating families were identified (table 9, at end of report). At 107 sites, all measurements fit a single rating family.

As an example of the classification process, the plots for 01668000, Rappahannock River near Fredericksburg, VA, showed two rating families (fig. 5). Measurements from the establishment of the streamgage until 2000 generally clustered together on the plot of flow relative to gage height. The timeseries plots of residuals show occasional scatter and outliers but no obvious trend, whether stepped or gradual. In 2000 , however, the relation between gage height and flow changed. Points on the gage height-flow plot that represent later measurements have a different slope than the previous points. This is seen in the residual of flow time series as greatly increased scatter beginning in 2000. Site records indicate that the streamgage was moved in October 2000. Measurements made before October 2000 are designated as belonging to Rating Family (RF) 1 and subsequent measurements as belonging to RF2. Curves are then fit separately to each rating family; residuals were captured from the curves and plotted as time series and by Julian date for each rating family. The new curve for RF2 fits those points better than the original curve fit all points. The coefficient of determination $\left(\mathrm{R}^{2}\right)$ for $\mathrm{RF} 1$ is higher than that for the entire set of measurements $(0.989$ as compared to 0.9700$) ; \mathrm{R}^{2}$ for RF2 is lower $(0.9550)$. The time series indicates that since 2000 , residuals have been negative or that less flow is associated with a given gage height. This may be the result of a long-term increase in deposition on the control or possibly some seasonal increase in macrophyte growth. If macrophyte growth were the likely cause, it might show up as large, negative residuals during summer and fall. This is in fact reflected in the time-series plot, although most of the recent winter measurements are lower than any measurements made before 2003. The plots of residuals and Julian date show little seasonal change for RF1, although variability was generally greater for the second half of the year. For RF2, overall variability is greater than for RF1, but the LOESS curve dips during summer when macrophyte growth is generally at its maximum.

At 67 sites, two or more rating families were identified. The maximum number of rating families was 7 at Chestnut
Creek at Galax, for a total of 127 rating families that were delineated as separate. Of these 127 rating families, documented explanations were found for 67 . The most common reasons for the control to change enough to represent a new rating family were moving the streamgage (28 times); floods (26 times); and construction activities, including bridge construction and removal, weir and control construction and removal, and channel or bed modifications (13 times). Sixteen of the rating families were classified at the end of a period of no data, including hiatuses in operation and periods when the streamgage was operated but measurements were not entered to the database. Forty-two rating families were identified from graphical appearance of the plots; eight of these had inconclusive or ambiguous documentation of stream channel changes.

Rating family changes related to floods represent a type of major change which real-time flow-data users might be able to anticipate. Of the 25 new rating families that were created by floods, most (18) were caused by major floods that changed ratings at more than one streamgage. The November 1985 flood caused by Hurricane Juan caused 9 of these changes, the June 1972 flood caused by Hurricane Agnes caused 3, and 2 each were caused by the August 1969 flood (Hurricane Camille), the January 1996 flood, and the September 1996 flood (Hurricane Fran). A major flood may cause a substantial rating change in any stream. Floods caused major rating changes in mountain streams with highly stable bedrock, or bedrock and boulder channels, although other nearby streams that also experienced major floods from the same storm showed small or no changes. Provisional flow data from any streamgage that has recently experienced a major flood, regardless of historical stability, is more uncertain than usual until post-flood evidence emerges that the rating remained stable or has again been well defined.

In many cases, clusters of several consecutive measurements temporarily departed from the time series; these were included for analysis but checked for explanations. Often, the departure was caused by human activities, such as a construction of a temporary dam used to facilitate bridge construction. Sometimes the departure was caused by beaver activity. Construction that subsequently affects the stage-flow relation at a streamgage typically will be reported to USGS in advance, and the information is likely to be made available to waterdata users. Beaver activity is difficult to anticipate but highly persistent. The presence of active beaver populations can be regarded as a characteristic of a site, as well as a strong predictor of degraded quality of flow records.

Flow measurements made when the stream is at or near flood stage are typically included in rating analysis for years or decades, and ratings are carefully fitted through them. Although changes are sometimes observed in the high end of ratings and repeated flood measurements must be made whenever possible, the practice of including historical highflow measurements in ratings has been supported by repeated observations at many sites. Because these measurements are used to develop currently active ratings, the measurements are commonly included in NWIS, even if low-flow measurements 
that were made during the same years have never been entered into the database. The high-flow measurements often show up as outliers on the time-series plots, however, because GAM curves developed for this study and fit to the full set of measurements sometimes miss these points and because these measurements are isolated in time. The high-flow measurements were included, even when they appeared to be outliers through an artifact of curve fitting, and represent one of the sources of error in the $\mathrm{R}^{2}$ of the GAM models.

Measurements made since the full implementation of NWIS in 1988 are intended to include information on whether or not the measurement was known to be in error and therefore excluded from the rating study during the year it was made. Common reasons for not being used include equipment failure or interference caused by flowing debris. Measurements made prior to the development of NWIS that were subsequently entered did not necessarily include this information. Measurements were screened as outliers both visually, from the plots, and by a check of divergence of four standard deviations from a running average of residuals in the time series. Greater effort was made to confirm visual outliers that indicated unusually high flow for a given gage height than was made for the opposite. Outliers indicating unusually high flow, when they result from accurate measurements, indicate temporary scour in the control. Temporary scour is less common than temporary backwater. When field or office notes indicated that outliers were considered to be unreliable measurements when they were made, they were excluded from analysis.

One of the limitations of the rating family classification is that, because classification was done graphically, it was subjective. Two alternate approaches were explored in an attempt to address this limitation. First, broken-stick regression and change-point analysis were explored but rejected as potential objective methods for classifying rating families. When applied to data from sites with clearly identified rating family changes that corresponded to well-documented causes, neither correctly identified the rating families. Second, the existing rating families were examined on an expanded scale. Rating families were further subdivided, and explanations were sought for the 108 new candidate rating families that were identified. Few of the new candidate rating families could be matched with explanatory events; only 1 of 108 candidates could be matched with remarks in the database or with measurement front sheets. Although base ratings were available for some of these candidate rating families, the base ratings generally changed at different times than this group of rating families. Because of the lack of corroborating evidence, this entire set of rating families was considered generally invalid and was abandoned.

During iterations of the curve fitting, GAM curves that modeled gage height as a smoothing function of flow $\left(\mathrm{GAM}_{\mathrm{GH}}\right)$ and that modeled flow as a smoothing function of gage height $\left(\mathrm{GAM}_{\mathrm{O}}\right)$ were developed and compared. The former curves follow the same convention as USGS streamgage ratings. Gage height is on the y-axis of a plot, and like actual stream rises and recessions, shows up as a vertical change. The latter curves, flow modeled as a function of gage height, seem superficially to mimic flow computation that might be done in a situation where gage height was known and flow is computed from an equation; however, for actual streamgages, flow is more commonly determined from gage height using database operations and matching a lookup table than computed from an equation. Both of these formats had advantages. When gage height is used on the y-axis as the dependent variable, stream filling and downcutting are portrayed in the same direction as they move in the physical world. When flow is used as the dependent variable, it facilitates comparison among sites for some purposes, although the relative importance of an arbitrary unit of flow is greater in a small creek than a large river.

The two sets of GAM models were compared graphically. For most sites, both models fit the available data equally well (215 of 301 rating families). The $\mathrm{GAM}_{\mathrm{GH}}$ models showed a better visual fit about twice as often as the $\mathrm{GAM}_{\mathrm{O}}$ models (56 and 23 rating families, respectively). For the other seven rating families, neither model was judged to fit well.

Error terms for the two sets of GAM models, as well as Spearman's rho correlation coefficients for gage height and flow within each rating family, were compared to the stability classes on the basis of expert judgement. Setting the classes Excellent, Good, Fair, and Poor equal to, 4, 3, 2, and 1, respectively, and performing correlation analysis resulted in Spearman's rho correlation coefficients among rating families of 0.3790 for $\mathrm{R}^{2}$ for $\mathrm{GAM}_{\mathrm{O}},-0.4687$ for Spearman's rho within each rating family, and 0.2982 for $\mathrm{R}^{2}$ for $\mathrm{GAM}_{\mathrm{GH}}$. Boxplots of these two error terms showed slightly more separation among classes for the $\mathrm{R}^{2}$ of $\mathrm{GAM}_{\mathrm{Q}}$ than the other two terms (fig. 6). The better correlation among sites between stability classes for the $\mathrm{R}^{2}$ of $\mathrm{GAM}_{\mathrm{Q}}$ than for $\mathrm{R}^{2}$ of $\mathrm{GAM}_{\mathrm{GH}}$ was contrary to the visual inspection of plots. Plots for those sites with a relatively high $\mathrm{R}^{2}$ for $\mathrm{GAM}_{\mathrm{Q}}$ and a relatively low $\mathrm{R}^{2}$ for $\mathrm{GAM}_{\mathrm{GH}}$ indicate that those sites predominantly had insensitive controls or controls where, at the low end of the rating, the change in flow was large relative to the change in stage.

Owing to the iterative nature of the analysis in this study, several stability metrics that have not yet been discussed in this report were important to the final line of evidence used to select $\mathrm{GAM}_{\mathrm{Q}}$ over $\mathrm{GAM}_{\mathrm{GH}}$ as the preferred model for fitting measurements. The section "Relations Among Stability Metrics" farther on describes the manner in which the proposed metrics that were determined to be meaningful showed stronger correlations among sites with $\mathrm{R}^{2}$ for $\mathrm{GAM}_{\mathrm{Q}}$ than among sites with $\mathrm{R}^{2}$ for $\mathrm{GAM}_{\mathrm{GH}}$. 

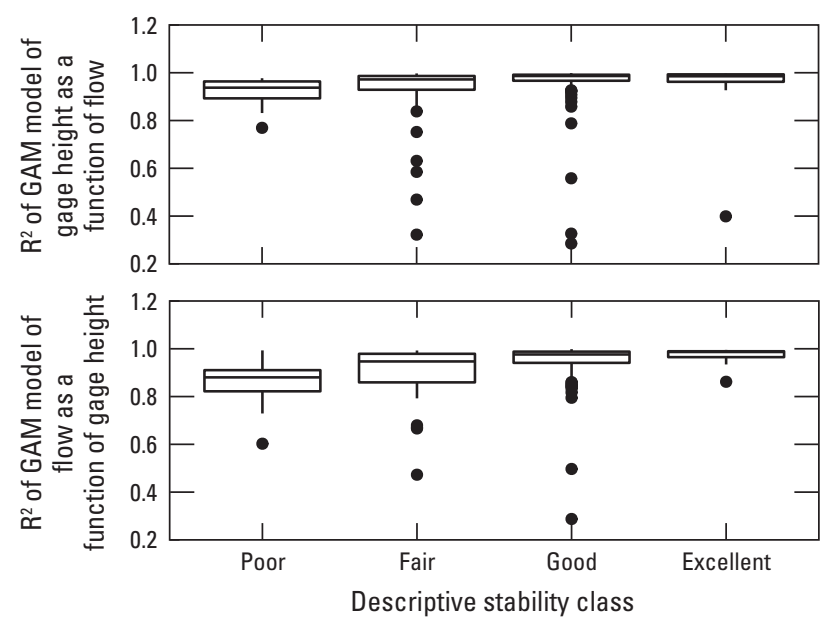

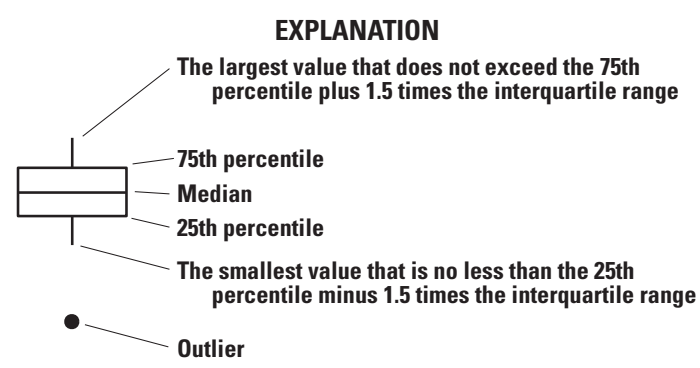

Figure 6. Distribution of variability metrics for stage-flow relations, by descriptive stability class, for streamgages in Virginia active on September 30, 2013. (GAM, generalized additive model; $R^{2}$, coefficient of determination)

\section{Seasonal Changes to Stage-Flow Relations}

Residuals from the fitted stage-flow curves, plotted by Julian date, show differences in rating stability throughout the year (appendix 1). Ratings can be grouped into three general classes. The first class, which is represented by 03173000 , Walker Creek at Bane, VA, generally has been stable through time and at all times of the year (plate 1). At these sites, established ratings change rarely, if ever, and temporary shifts are also rare. At Walker Creek, the $\mathrm{R}^{2}$ of the $\mathrm{GAM}_{\mathrm{Q}}$ model is 0.9966 , and all available measurements fit a single rating family. A handful of low outliers, representing backwater conditions, have been observed. Most of these outliers were in the winter, and they were likely caused by ice.

The second class, which is represented by 01631000 , South Fork Shenandoah River at Front Royal, VA, is generally stable through time and consistent during winter and spring but usually shifts in the summer or fall. At these sites, the bed is typically stable, but seasonal plant growth or leaf accumulation on the control is routine. Although routine, the magnitude, duration, and timing of these shifts are different every year, and preliminary flow data at these sites might or might not need to be corrected. At South Fork Shenandoah River at Front Royal, all measurements fit a single rating family, the trend line for the long-term time series is generally flat, and $\mathrm{R}^{2}$ of $\mathrm{GAM}_{\mathrm{Q}}$ is 0.9694 . There have been two periods when macrophyte or leaf shifts were unusually large, in the 1950s and since about 1988. Most of the low outliers were between Julian dates 200 and 300, or July through October. The control description (table 8 ) discusses shifting caused by aquatic growth and leaf fall; subsequent accumulation of leaves in streams rarely begins before September, so the largest shifts likely were caused by macrophyte growth.
The third class, which is represented by 01658500 , South Fork Quantico Creek near Independent Hill, VA, especially RF1, is somewhat unstable at all times of the year. Rating instability at these sites is likely to be the result of a shifting, unstable bed. As at South Fork Quantico Creek, these sites are commonly subject to seasonal shifting as well. Although shifts are frequent at this site, they are not huge and scour is usually followed by fill. An exception was a flood in 1990 that caused a new rating family, but neither rating family had extreme variance; $\mathrm{R}^{2}$ was 0.9160 for RF1 and 0.9372 for RF2.

A banding pattern similar to that in the plot of residuals by Julian date for 02030500 , Slate River near Arvonia, VA, is seen for some of the sites (plate 1). This pattern was investigated to determine whether it was an artifact of Julian date computation or was some other type of artifact. It was real. It shows up at sites operated by field offices that maintained the same field trip schedule consistently throughout the period of record. At these sites, measurements were consistently made the same weeks of each year.

\section{Long-Term Changes to Stage-Flow Relations}

Patterns in rating residuals plotted as a time series show that ratings tend to reach equilibria of varying stability punctuated by disruptive events. Disruptive events, as demonstrated by the explanations for rating families (table 9), include major floods and human construction activities. The equilibria, generally, reflect conditions when a stable or relatively stable feature has formed or been built and that feature serves as the control. The time to equilibrium varies depending on the nature of the stream channel and the disruptive event. Disruptive events, such as weir construction, led to almost immediate 
equilibria, but some floods caused changes that took extended periods to reach new equilibria.

Two examples of sites at which controls were changed by floods, but different amounts of time were needed to become stable, are 02021500, Maury River at Rockbridge Baths, VA, and 03207800, Levisa Fork at Big Rock, VA (plate 2). At the Maury River streamgage, where the channel is composed of bedrock and large boulders, the January 1996 flood altered the control so that flow at a given gage height increased. Because it increased throughout the range of stage, as shown by nearly all points that fall above the GAM curve on the stage-flow plot representing recent measurements, the control alteration might have been a large boulder moved downstream by the flood. Despite this change, all the measurements at this site were designated as belonging to a single rating family, with an $\mathrm{R}^{2}$ of 0.9935 . At the Levisa Fork streamgage, where the control is cobble and boulder, the April 1978 flood destabilized the control. Prior to this flood, the control exhibited regular but relatively minor seasonal shifting. After the flood, variability increased, and the channel began to downcut. Following a major but undocumented change in 1988, variability decreased, but downcutting continued until about 2005. In 1978, a flow measurement of 57.9 cubic feet per second $\left(\mathrm{ft}^{3} / \mathrm{s}\right)$ was made at a gage height of $4.12 \mathrm{ft}$; in 2013, a flow measurement of $61.1 \mathrm{ft}^{3} / \mathrm{s}$ was made at a gage height of $2.58 \mathrm{ft}$. The downcutting is further corroborated by hydrographer observations that water levels in the pool decreased enough that the stilling-well intakes were above the water and required modification. All of the downcutting cannot be attributed to channel response to the 1978 flood, as opposed to land use and other possible activities, but that flood clearly was a disruptive event that marked the beginning of a period of change for the control.

Two other types of long-term changes to controls are illustrated in plate 2. Scour-fill changes are shown for 02065500, Cub Creek at Phenix, VA. At this streamgage, the control is sand and gravel, and it was affected by large woody debris. The earliest available data show that the stream was scouring the control until the late 1980s. It then filled over the next 10 to 12 years, while variability increased. In the early 2000 s, the stream began to scour again and has continued through 2013.

At 02040000, Appomattox River at Mattoax, VA, the low-water control is thought to be a channel constriction, but shifting is caused by accumulation of sand and gravel in the streambed. Measurements have not been continuously available since the establishment of this streamgage. The earliest available data show little variation. The second block of available data, from the 1920 s through the late 1950 s, shows decreasing flow at a given gage height, which indicates channel aggradation, filling, or possibly, if the low-water control is in fact a channel constriction, increased constriction. Data are available beginning in 1988. During the period when data were unavailable, the channel downcut or widened. Since 1988, however, the channel has been filling or constricting again, a pattern that increased about 2002. This site also exhibits seasonal shifting and, occasionally, a low measurement in the winter that might be affected by ice.

\section{Estimated Provisional Flows (AltFlows)}

Despite their limitations, provisional real-time flow data are indispensable for water managers. For some purposes, especially those related to flood warning and response, or for those for which precision is less important than relative change or timing, provisional data are likely to meet users' needs. Provisional low flows, however, are likely to be revised before they become final for three reasons. (1) Low flows are sensitive to small changes in the control. (2) Low flows are common during summer and fall, and coincide with algae and macrophyte growth and leaf accumulation. (3) Low flows can be technically challenging to measure accurately, especially in rough stream channels, leading to more erratic ratings in such streams. Low stage is also technically challenging to measure in response to sediment deposition and where controls are insensitive. For users of provisional flows, especially low flows, quantifying differences between provisional and final flows would provide valuable insight into the reliability of provisional flows.

A long-term comparison of provisional data against final data would provide a simple, direct measure of the changes that the data undergo through USGS processing and indicate the reliability of the provisional data for user decision making. Indeed, if provisional data were archived for the period of interest, a comparison between provisional and final data would be straightforward. However, provisional data are not archived. The USGS flow time-series database Automated Data Processing System (ADAPS) was developed in a time when data storage was much more expensive than it is now. Storing all preliminary and intermediate data was impractical until the late 1990s or early 2000s, and reworking the database to do so was not a high priority for data managers and software developers. For most sites, the storage of final, corrected unit values for gage height and flow began in the late 1990s or early 2000s. Paper tapes and data collection platform files were archived, but reconstructing a complete provisional time series from them would require several staff years of effort and was beyond the scope of this study. New software with a planned release date in 2017 is designed to include preservation of provisional data, as well as associated comments and computations that document and attribute each change in the data through time.

As a substitute for provisional flow data, an alternative series of daily flows (AltFlows; fig. 7) was developed (Messinger and Burgholzer, 2017). The primary steps were to acquire and compile ratings and daily flows for periods when ratings were available. Periods with complete records of shifts and ratings were identified. Daily flows were acquired for 


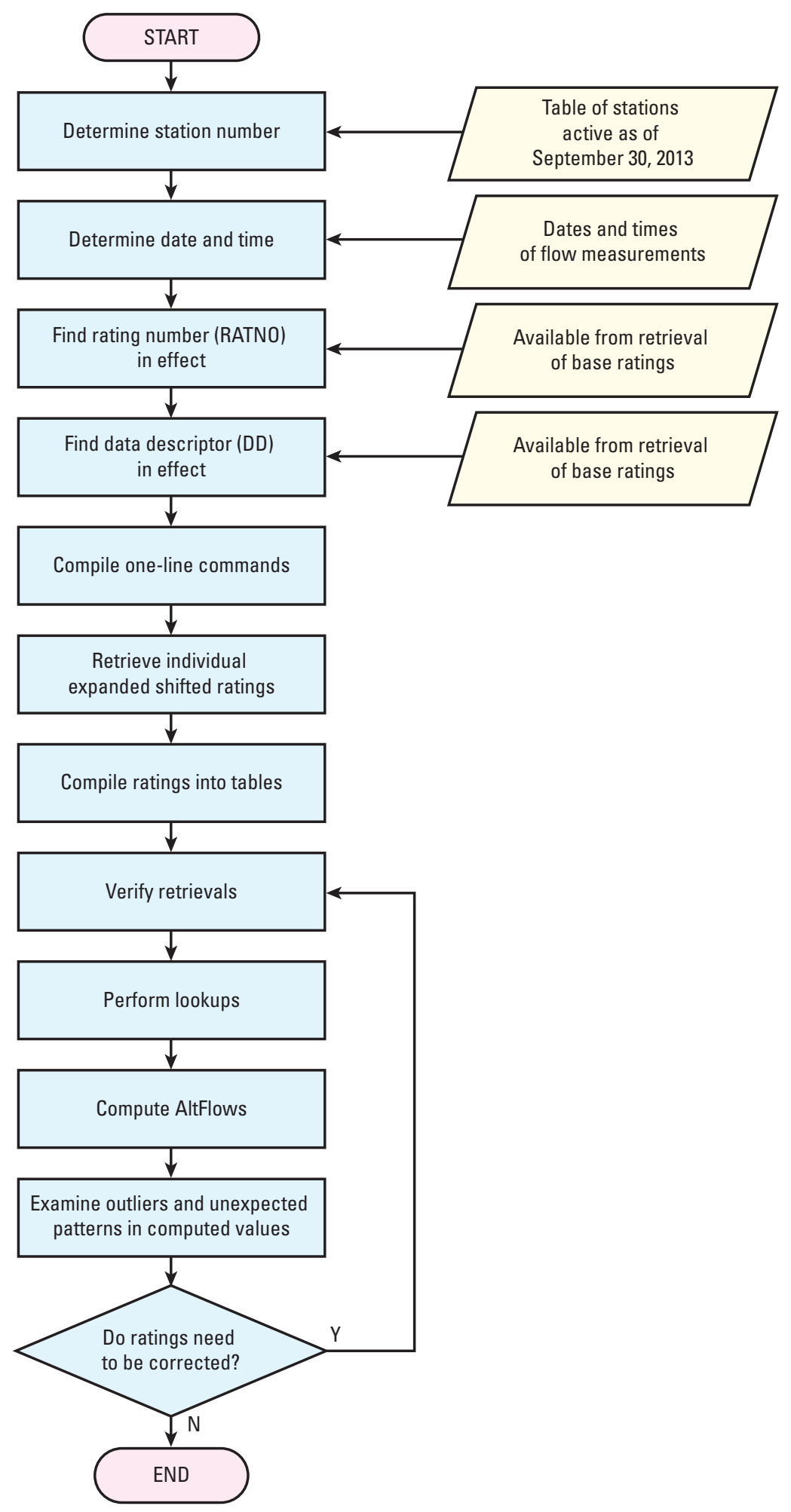

Figure 7. Major actions and data sources for computing alternative flow (AltFlow) tables for Virginia streams, water years 1991-2013. 
these periods. Expanded shifted ratings were acquired for days during these periods when flow measurements were made. Gage heights corresponding to mean daily flows were back calculated and identified as belonging to measurement-tomeasurement periods. These gage heights were then evaluated against two sets of ratings, those in effect when the measurement-to-measurement period began $\left(Q_{\text {same }}\right)$ and those in effect when the previous measurement-to-measurement period began $\left(Q_{\text {prev }}\right) \cdot Q_{\text {same }}$ was used instead of the published daily values to avoid rounding errors. Daily mean flows were computed by averaging the unit values for each day but often failed to correspond to the flow increments in rating tables (fig. 7).

Several important sources of error in provisional flow data that are corrected in final flow data are missed by this process. Most important and common are errors that are not caused by changes to the control, and therefore are not corrected by changing ratings or shifts. These errors include ice-affected flows or missing records, which generally are estimated by hydrographic comparison to other streamgages. Errors in the stage record itself are relatively common for some sites, especially those with substantial sediment loads. These errors might be corrected or at least adjusted, or daily flows might be estimated for the period that was in error.

Another difference between provisional and approved data not accounted for by this procedure is that expanded shifted ratings were selected as snapshots at the times when flow was measured, and the tens of thousands of other rating changes were ignored. Days when measurements were made have no particular relevance to the beginning or ending of shifts and rating changes. About one-third $(7,346$ of 23,126$)$ of shift entries began on days when flow was measured, and of these, 2,679 were apparently procedural entries for shifts that were implemented in multiple steps throughout the day. Forty-one percent of unique shifts $(6,842$ of 16,853$)$ began on days of peaks, either floods or high-flow pulses, and another 7 percent $(1,144$ of 16,853$)$ began the day after a peak; many of the shifts that began on days when measurements were made came on days of peaks and high-flow pulses. Prorating certain types of shifts through time is routine; the AltFlow procedure does not account for these changed shifts. As a result, the AltFlow time series is unlikely to have much relation to provisional data as they initially appeared on the web. It does, however, provide information on changes in the shifted rating from site visit to site visit and information on how the shifted rating changed throughout the range of observed flows.

\section{AltFlow Development}

AltFlow development involved inventory and assessment of ratings and shifts, acquisition of ratings and daily flow values, computation of $Q_{\text {same }}$ and $Q_{\text {prev }}$, and validation of these computations through a series of checks.

\section{Rating Availability, Acquisition, and Compilation}

Availability of ratings and shifts varied by streamgage (tables 3 and 4). Although daily flow values have been computed in NWIS since the adoption of the database, different centers and field offices archived different amounts of ancillary data, such as ratings and shifts, throughout the 1980s, 1990s, and into the 2000s. Electronic archiving of all shifts and ratings did not become universal and mandatory until the 2002 water year. Rating availability exceeded shift availability. All ratings and shifts were stored with their effective dates. Although a base rating may have been archived at a relatively late date, if it had been in effect previously, it was stored in association with its earliest available date. In some cases, the effective date preceded the development of NWIS. In these cases, however, there was no reason to go back and enter previous shifts, so they were never entered. However, there was no reasonable way to retrospectively tell the difference between cases when a base rating was entered after it had initially been developed and cases when a base rating without need for shifting was entered and used to compute flow values. Therefore, the beginning dates for potentially valid AltFlows data were set at the first date for each streamgage for which both a base rating and a shift were available. This procedure incorporates the assumption that all ratings and shifts that had been used were continuously available once they were initially available, which was impossible to check without site-by-site, year-by-year comparison of available data to printed station analyses. However, on review of a summary of the number of base ratings and shifts available by year (tables 3 and 4), the assumption seemed plausible.

As discussed previously, preferred approaches to dealing with rating changes may vary by analyst and field office. It was, however, straightforward to avoid arbitrary differences between ratings and shifts by using expanded shifted rating tables, the final rating tables used in the database to compute flow. As discussed previously, ratings and shifts change frequently, sometimes abruptly and sometimes gradually; they may be implemented at once, prorated over a few hours during a rise or recession, or prorated over several weeks when weeds are thought to have been growing or leaves are thought to have been accumulating. To make the task at hand less impractical, expanded shifted ratings were retrieved only for the times when flow measurements were made.

Retrievals of shifted ratings were made for the precise date and time of the measurement. On days when stage changes, the measurement checks only the segment of the rating near that same range of stage; stated another way, an instantaneous flow measurement provides a reliable check for a published daily value for a day when flow did not change. Accounting for measurement timing on the retrieval was particularly important because extra effort was made to catch 
high measurements, nearly all of which were made on days when flow changed.

Archived expanded shifted ratings were not readily available to the public, and retrievals required direct access to the command line of the Virginia Water Science Center NWIS server. The ratings that originally were not readily available to the public have been published (Messinger and Burgholzer, 2017). The tools and actions used to compute AltFlows are described in appendixes 2 and 3.

\section{Special Conditions Affecting Some AltFlows}

During the process of validating the AltFlow data, several extreme values were identified and investigated to determine whether they reflected (1) artifacts of the AltFlow development process, (2) special conditions related to the flow data collection and processing, or (3) exceptionally unstable controls. The extreme values that were identified as artifacts of the AltFlow development process were corrected. All the artifacts that were identified resulted from errors in the expanded shifted rating retrieval that in turn resulted from complications in the manner in which ratings were coded and stored. Special conditions related to flow data collection and processing that affected some AltFlows are discussed below. Other special conditions that resulted in modest rather than dramatic effects to AltFlows may have gone unnoticed.

\section{Streamgage Datum Changes}

On occasion, generally in response to scour at the streamgage control, the datum of the streamgage is changed. Often the change is made in order to avoid a zero or negative gage height, which would be undefined on log-scale plots; datum changes are always or nearly always positive because there is no practical reason to make a negative datum change. Datum changes are typically made in increments of one or more feet. Large datum changes (3 feet or more) would typically be made if continued scour was anticipated. Because the datum is arbitrary in the first place, these datum changes are made for the convenience of the hydrographers. The datum change itself is inconvenient, so datums are changed rarely.
Datum changes were made six times at streamgages for which valid AltFlows could have been computed (table 10). The sets of ratings for these six sites were adjusted for datum corrections. They are the only sites in the study to which a datum correction was applied during a period when valid AltFlows could have been computed. For each of the sites in table 10, the appropriate number of rows (200 for the three sites with 2.00-foot datum corrections, 300 for the sites with the 3.00-foot datum correction, and 3,099 for the sites with the 30.99 -foot datum correction) was inserted into the columns representing expanded shifted ratings for all dates prior to the datum correction. All stage measurements in the rating tables now represent the same datum for each site. No manual change had to be made for the flow table; once the ratings were adjusted, the lookup functions were able to find the corrected gage heights without any further modification.

\section{Moving a Streamgage}

Sometimes it is necessary to move a streamgage. Reasons include, but are not limited to, stream channel migration away from the streamgage location, frequent deposition of sediment on the intake or orifice, demolition of a bridge or other structure to which the streamgage is attached, construction of a bridge or other structure that interferes with streamgage operation, structural damage to a gaging structure, and determination that a control is unstable and better record could be obtained elsewhere on the same stream.

Streamgages are sometimes moved from one location to another within the same gaging pool. Under these circumstances, when the new streamgage location uses the same control, little if any change to the rating is to be expected. Otherwise, changes to the rating after the move are unsurprising, and comparing ratings from before and after the move provides no information on rating stability. Not only that, but when a streamgage is moved somewhere with a different control, standard procedure is to stop publishing preliminary flow data to the web until the new rating has been established, which generally takes several months.

Three streamgages were moved to new gaging pools during water years 2013 (table 11). Two of these moves, for

Table 10. Locations, magnitudes, and dates of datum changes for streamgages in Virginia, water years 1990-2013.

[VA, Virginia]

\begin{tabular}{clcc}
\hline $\begin{array}{c}\text { Streamgage } \\
\text { number }\end{array}$ & \multicolumn{1}{c}{ Streamgage name } & $\begin{array}{c}\text { Magnitude of } \\
\text { datum change, } \\
\text { in feet }\end{array}$ & $\begin{array}{c}\text { Date of } \\
\text { datum } \\
\text { change }\end{array}$ \\
\hline 02011460 & Back Creek near Sunrise, VA & 2.00 & $10 / 28 / 2008$ \\
02027000 & Tye River near Lovingston, VA & 2.00 & $9 / 3 / 2004$ \\
02027500 & Piney River at Piney River, VA & 3.00 & $11 / 3 / 2009$ \\
02061500 & Big Otter River near Evington, VA & 2.00 & $6 / 9 / 2005$ \\
02077000 & Banister River at Halifax, VA & 3.00 & $9 / 24 / 2002$ \\
02047500 & Blackwater River near Dendron, VA & 30.99 & $11 / 28 / 2012$ \\
\hline
\end{tabular}


01615000, Opequon Creek near Berryville, and 01662800, Battle Run near Laurel Mills, coincided with discontinuation of the streamgage. The third, 01668000, Rappahannock River near Fredericksburg, was moved to a new gaging pool in March 2001 owing to safety and access concerns. Values of $Q_{\text {same }}$ were deleted for the period between the streamgage move and the next flow measurement, and values of $Q_{\text {prev }}$ were deleted until the subsequent flow measurement.

\section{Suspension of Streamgage Operations}

When streamgages are discontinued but later reactivated, the old rating remains in the database and might be used as a temporary rating to generate provisional data while measurements are being made either to verify it or to generate a new rating. These provisional data would not ordinarily be published to the web before the rating was verified, so a comparison between the old rating and the updated rating would ordinarily not be useful.

Eighteen streamgages were discontinued for 30 days or longer, but were later reactivated, during water years 1991-2013 (table 12). For eight of these streamgages, the hiatus came before the earliest valid AltFlow date (varying by site; the earliest date at which two flow measurements had been made after shifts and ratings began to be stored in the database).

For the 10 streamgages for which the hiatus came during a period with potentially valid AltFlows, the AltFlow daily values were not computed using the pre-hiatus rating. $Q_{\text {prev }}$ values were resumed once two flow measurements had been made following the hiatus.

\section{Estimated and Qualified Daily Flows}

As discussed previously, at times when stage record is missing or in error, daily values are estimated. Errors in stage record may be caused by instrument failure, sediment deposition on the intake or orifice, or ice effect. Estimates may be based on partial record at the streamgage being estimated or on hydrographic comparison with nearby streamgages known to be correlated with the streamgage being estimated. Weather records are checked for rain or freezing temperatures.

A critical issue for purposes of this study is that daily flow values may be estimated without any use of the streamgage's rating. Nearly as important, if flow is to be estimated for a small amount of record and limited to part of the hydrograph where a shift might be needed if flow were to be computed, the need for a shift is moot. These factors represent limitations of the AltFlow approach, and AltFlows have little relevance for periods of estimated records.

The total percentage of estimated days at a streamgage may be a reasonable surrogate for quality of the stage record. For days when AltFlow record was developed, 4 percent of the overall record combined from all streamgages was estimated. Ten percent or more of the overall record was estimated for seven sites (01643805, North Fork Goose Creek at Route 729 near Lincoln; 02032250, Moormans River near Free Union; 02079640, Allen Creek near Boydton; 01660400, Aquia Creek near Garrisonville; 01616100, Dry Marsh Run near Berryville; 01654000, Accotink Creek near Annandale; and 02040000, Appomattox River at Mattoax; table 13, at end of report).

The number of estimated days during the winter may be a fair surrogate for the amount of ice effect at a streamgage, in particular for streams where little record is estimated during other seasons (table 13). For the entire network during water years 1991-2013, 7 percent of the overall winter record (December, January, and February) was estimated. January was the month with the greatest rate of estimated record, and 28 percent of the overall estimated days were during January. At 5 streamgages, 20 percent or more of winter record was estimated; 10 percent or more of winter record was estimated at 54 streamgages. Most streamgages with a high rate of estimated record during the winter were at high elevations or had small drainage areas. At 26 streamgages, 1 percent or less of winter record was estimated; at 14 of those, 0 percent of winter record was estimated. Most of these streamgages were on large rivers, directly downstream from dams, or had a short period of record.

At one site (02077000, Banister River at Halifax, VA) daily flows were estimated on 230 days from 1999 through 2002 because valid stage measurements were not available. Estimates were based on hydrographic comparison with other streamgages. This happened on days when the gage height was missing because stage was low enough that the stilling-well intake was out of the water. These days also lack a value for $Q_{\text {prev }}$, even though apparently valid previous ratings exist. Because the original stage record was missing,

Table 11. Streamgages that were moved to new gaging pools, and dates of the move, in Virginia, water years 1991-2013.

[Gages that were moved to new locations in the same gaging pool with the same control are not included; VA, Virginia]

\begin{tabular}{clc}
\hline $\begin{array}{c}\text { Streamgage } \\
\text { number }\end{array}$ & \multicolumn{1}{c}{ Streamgage name } & $\begin{array}{c}\text { Date the gage } \\
\text { was moved }\end{array}$ \\
\hline 01615000 & Opequon Creek near Berryville, VA & $10 / 15 / 2002$ \\
01662800 & Battle Run near Laurel Mills, VA & $10 / 3 / 1997$ \\
01668000 & Rappahannock River near Fredericksburg, VA & $3 / 6 / 2001$ \\
\hline
\end{tabular}


Table 12. Virginia streamgages that were discontinued and reactivated for 30 or more consecutive days, and the dates they were discontinued and reactivated, water years 1991-2013.

[AltFlow, alternative flow tables; VA, Virginia]

\begin{tabular}{|c|c|c|c|c|}
\hline $\begin{array}{c}\text { Streamgage } \\
\text { number }\end{array}$ & Streamgage name & $\begin{array}{l}\text { Date } \\
\text { discontinued }\end{array}$ & $\begin{array}{l}\text { Date } \\
\text { reactivated }\end{array}$ & Date AltFlow resumed \\
\hline 01615000 & Opequon Creek near Berryville, VA & $10 / 19 / 1997$ & $10 / 1 / 2002$ & $12 / 10 / 2002$ \\
\hline 01626850 & South River near Dooms, VA & $12 / 10 / 1996$ & $7 / 21 / 2005$ & $10 / 14 / 2005$ \\
\hline 01660400 & Aquia Creek near Garrisonville, VA & $10 / 15 / 1997$ & $11 / 4 / 1999$ & $\begin{array}{l}\text { No lost AltFlow record; } \\
\text { no valid AltFlows from before hiatus }\end{array}$ \\
\hline 01665500 & Rapidan River near Ruckersville, VA & $6 / 30 / 1995$ & $10 / 1 / 1998$ & $\begin{array}{l}\text { No lost AltFlow record; } \\
\text { no valid AltFlows from before hiatus }\end{array}$ \\
\hline 01670400 & North Anna River near Partlow, VA & 9/30/1995 & $3 / 27 / 2007$ & $5 / 1 / 2007$ \\
\hline 01671100 & Little River near Doswell, VA & 9/30/1999 & $9 / 22 / 2000$ & $\begin{array}{l}\text { No lost AltFlow record; } \\
\text { no valid AltFlows from before hiatus }\end{array}$ \\
\hline 02030500 & Slate River near Arvonia, VA & $10 / 15 / 1995$ & $6 / 23 / 2005$ & $8 / 2 / 2005$ \\
\hline 02032250 & Moormans River near Free Union, VA & 9/30/1997 & $7 / 7 / 2005$ & $\begin{array}{l}\text { No lost AltFlow record; } \\
\text { no valid AltFlows from before hiatus }\end{array}$ \\
\hline 02077000 & Banister River at Halifax, VA & $11 / 10 / 2011$ & $3 / 1 / 2012$ & $3 / 25 / 2012$ \\
\hline 02079640 & Allen Creek near Boydton, VA & $10 / 20 / 1996$ & $10 / 1 / 2000$ & $11 / 29 / 2000$ \\
\hline 03175500 & Wolf Creek near Narrows, VA & $9 / 30 / 1995$ & $10 / 1 / 1996$ & $11 / 12 / 1996$ \\
\hline 03177710 & Bluestone River at Falls Mills, VA & $4 / 27 / 1997$ & $9 / 22 / 2004$ & $12 / 8 / 2004$ \\
\hline
\end{tabular}


the hydrographer had no practical reason to develop a rating for that range of stage, and therefore there was no defined gage height that corresponded to the daily flows for those days. This ended in September 2002, when the stilling well was replaced with a bubbler system that could measure lower stage values, and the datum was changed.

Retrievals of daily flow values include, by default, a column of qualifiers. The qualifier for estimated flows (A:e) is one of these. Two other qualifiers were common. The first and by far the most common is A, for approved, indicating that flows were computed in the usual way. The second is A:1, which is described in comment fields as indicating that daily flow values are write-protected without any remark code to be printed. What this typically means in practice is that for some reason, the stage recorder collected a partial day of record while flow was stable, and the mean daily flow computed from available values was judged to characterize the day.
Unit values would have been recorded under a different data descriptor (DD), and particularly early in the 1990s, they may have been processed under that DD and entered manually into the daily flow table. In such cases, these values might potentially have been developed from a different rating than the one used for the development of AltFlows. These values represent less than one-half a percent of the total record for which AltFlows were developed.

\section{Days of Zero Flow}

An observation of zero flow can be associated with more than one gage height; once flow decreases to zero, the stage of the gaging pool can continue to decrease as flow remains zero. On days when AltFlows were calculated, $Q_{\text {meas }}$ was observed a total of 2,620 days at 26 streamgages (table 14). At four sites, zero flow was observed 100 or more times, with a maximum

Table 14. Number of days with zero flow for streamgages in Virginia, water years 1991-2013.

[VA, Virginia; Rt, Route]

\begin{tabular}{clr}
\hline $\begin{array}{c}\text { Streamgage } \\
\text { number }\end{array}$ & \multicolumn{1}{c}{ Streamgage name } & $\begin{array}{c}\text { Days of } \\
\text { zero flow }\end{array}$ \\
\hline 01638350 & South Fork Catoctin Creek at Rt 698 near Waterford, VA & 28 \\
01638420 & North Fork Catoctin Creek at Rt 681 near Waterford, VA & 110 \\
01643700 & Goose Creek near Middleburg, VA & 52 \\
01643880 & Beaverdam Creek at Rt 734 near Mountville, VA & 196 \\
01645704 & Difficult Run above Fox Lake near Fairfax, VA & 6 \\
01654000 & Accotink Creek near Annandale, VA & 14 \\
01656000 & Cedar Run near Catlett, VA & 4 \\
01658500 & South Fork Quantico Creek near Independent Hill, VA & 51 \\
01660400 & Aquia Creek near Garrisonville, VA & 1 \\
01662800 & Battle Run near Laurel Mills, VA & 1 \\
01669000 & Piscataway Creek near Tappahannock, VA & 24 \\
01669520 & Dragon Swamp at Mascot, VA & 56 \\
01673550 & Totopotomoy Creek near Studley, VA & 35 \\
01673800 & Po River near Spotsylvania, VA & 8,620 \\
01674000 & Mattaponi River near Bowling Green, VA & 158 \\
02030000 & Hardware River below Briery Run near Scottsville, VA & 72 \\
02031000 & Mechums River near White Hall, VA & 1 \\
02032250 & Moormans River near Free Union, VA & 26 \\
02037000 & James River And Kanawha Canal near Richmond, VA & 775 \\
02041000 & Deep Creek near Mannboro, VA & 5 \\
02046000 & Stony Creek near Dinwiddie, VA & 4 \\
02047500 & Blackwater River near Dendron, VA & 3 \\
02049500 & Blackwater River near Franklin, VA & 12 \\
02051000 & North Meherrin River near Lunenburg, VA & 5 \\
02065500 & Cub Creek at Phenix, VA & 1 \\
02079640 & Allen Creek near Boydton, VA & \multicolumn{1}{c}{ Total } \\
\hline & & \multicolumn{1}{c}{. } \\
\hline
\end{tabular}


of 972 days of zero flow at 02047500 , Blackwater River near Dendron.

Because an observation of zero flow is of particular concern to water managers interested in knowing the reliability of provisional flow during low-flow periods, these observations were all retained, and $Q_{\text {same }}$ and $Q_{\text {prev }}$ were computed for them, despite some ambiguity in back calculating their gage heights.

$Q_{\text {same }}$ and $Q_{\text {prev }}$ were not always zero on the same dates. Values of zero flow for $Q_{\text {same }}$ were computed on 697 days when $Q_{\text {prev }}$ had flows at 13 sites (table 15). At these sites, mean values of $Q_{\text {prev }}$ ranged from $0.01 \mathrm{ft}^{3} / \mathrm{s}$ to $136 \mathrm{ft}^{3} / \mathrm{s}$. Values of zero flow for $Q_{\text {prev }}$ were computed on 1,023 days when $Q_{\text {same }}$ had flows at 19 sites (table 16). At these sites, mean values of $Q_{\text {prev }}$ ranged from $0.01 \mathrm{ft}^{3} / \mathrm{s}$ to $87.6 \mathrm{ft}^{3} / \mathrm{s}$. For both of these characteristics, the same site (02037000, James River and Kanawha Canal near Richmond, VA) had the maximum value when a zero value was observed for the other characteristic.

\section{Previously Undefined Ratings}

One of the circumstances for which $Q_{\text {prev }}$ could not be computed when a valid previous rating was available was when stage entered a range where it was undefined in the previous rating. This happened for two different reasons, either (1) scour to the control, which resulted in ordinary flows becoming associated with unprecedented low stage, or (2) flows were higher or lower than had previously been measured.

One fairly common scenario concerning undefined ratings was where the control scoured to an elevation lower than previously defined in the rating. When this happens, the streamgage's real-time page displays a clearly labeled red line showing the minimum plausible limit of the rating as designated by the field office. Preliminary flow data lower than this threshold are not published to the web, and an explanation is provided on the real-time page. In this retrospective analysis, however, these scour events resulted in periods during which a valid previous rating had been in effect but $Q_{\text {prev }}$ was missing.

While not necessarily more problematic than any other undefined ratings for real-time flow data users, ratings for which zero flow was undefined were a complication for computing $Q_{\text {prev }}$. If the previous rating included a gage height at which flow was zero, flow remained zero for all lower gage heights, so that strictly speaking, the value of these gage heights was defined. If the minimum defined flow was greater than zero, then $Q_{\text {prev }}$ represented a non-detect. The lowest defined flow represented a detection limit, and flows lower than that were known only to be lower than the detection limit. Water-quality analysts frequently work with concentration data that represent quantification at less than a detection limit and do so using a variety of approaches, all of which have some advantages but none of which is completely satisfactory for all purposes (Helsel and Hirsch, 2002). For purposes of this analysis, the $Q_{\text {prev }}$ values that were less than a nonzero threshold were arbitrarily set equal to the minimum flow value defined in the relevant rating - the detection limit - because VDEQ water managers determined the most likely guidance that they would give holders of withdrawal permits who asked about missing values in this circumstance would be to assume flow was equal to the last posted value until new flow values

Table 15. Number of days when $Q_{\text {same }}$ equaled zero but $Q_{\text {prev }}$ did not, and mean and maximum values of $Q_{\text {prev }}$ for those days for streamgages in Virginia, water years 1991-2013.

$\left[Q_{\text {prev }}\right.$, the flow value from the shifted rating table in effect at the time of the previous flow measurement that corresponds to the gage height of each day's daily flow value; $Q_{\text {same }}$, the flow value from the shifted rating table used to compute the daily flow value at the time of the most recent flow measurement that corresponds to the gage height of each day's daily flow value; $\mathrm{ft}^{3} / \mathrm{s}$, cubic feet per second; VA, Virginia; Rt, Route]

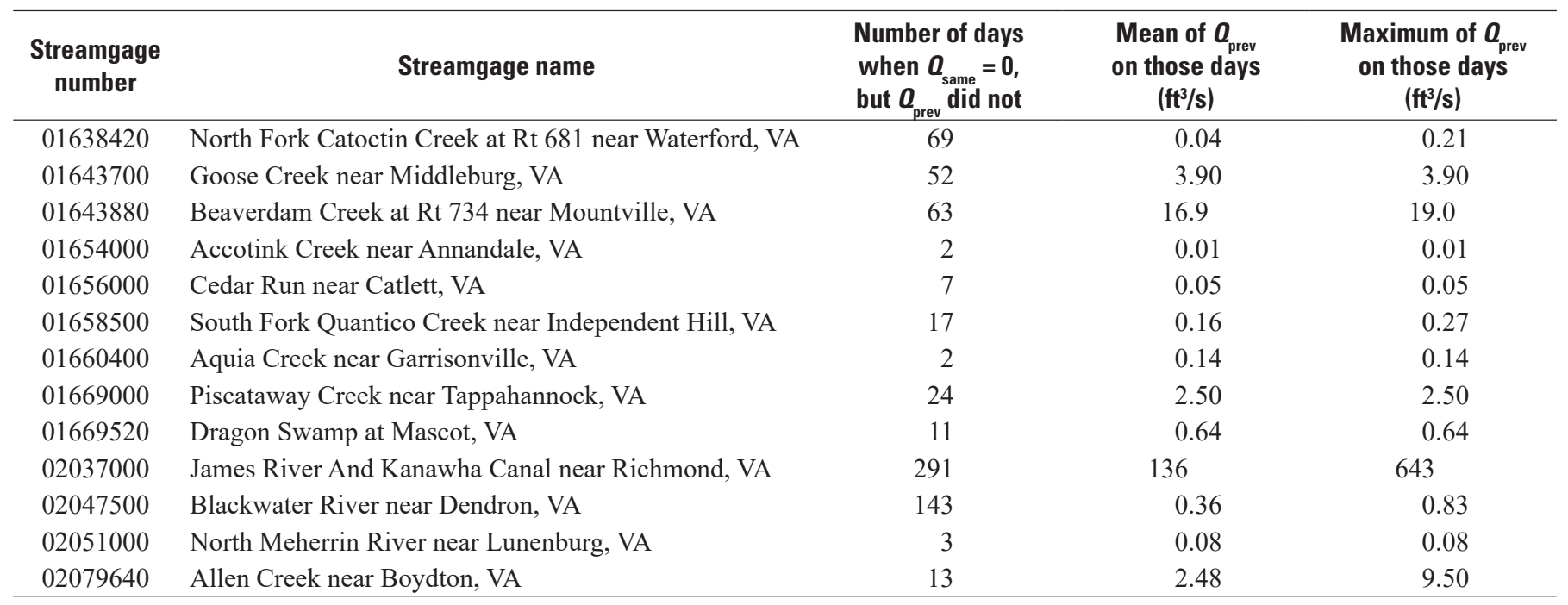


Table 16. Number of days when $Q_{\text {prev }}$ equaled zero but $Q_{\text {same }}$ did not, with mean and maximum values of $Q_{\text {prev }}$ for those days for streamgages in Virginia, water years 1991-2013.

$\left[Q_{\text {prev }}\right.$, the flow value from the shifted rating table in effect at the time of the previous flow measurement that corresponds to the gage height of each day's daily flow value; $Q_{\text {same }}$, the flow value from the shifted rating table used to compute the daily flow value at the time of the most recent flow measurement that corresponds to the gage height of each day's daily flow value; =, equals; $\mathrm{ft}^{3} / \mathrm{s}$, cubic feet per second; VA, Virginia; Rt, Route]

\begin{tabular}{|c|c|c|c|c|}
\hline $\begin{array}{c}\text { Streamgage } \\
\text { number }\end{array}$ & Streamgage name & $\begin{array}{l}\text { Number of days } \\
\text { when } Q_{\text {same }}=0 \text {, } \\
\text { but } Q_{\text {prev }} \text { did not }\end{array}$ & $\begin{array}{c}\text { Mean of } Q_{\text {prev }} \\
\text { on those days } \\
\left(\mathrm{ft}^{3} / \mathrm{s}\right)\end{array}$ & $\begin{array}{c}\text { Maximum of } \boldsymbol{Q}_{\text {prev }} \\
\text { on those days } \\
\left(\mathrm{ft}^{3} / \mathrm{s}\right)\end{array}$ \\
\hline 01620500 & North River near Stokesville, VA & 43 & 16.3 & 43.0 \\
\hline 01638420 & North Fork Catoctin Creek at Rt 681 near Waterford, VA & 5 & 0.38 & 0.58 \\
\hline 01643880 & Beaverdam Creek at Rt 734 near Mountville, VA & 87 & 0.98 & 2.70 \\
\hline 01658500 & South Fork Quantico Creek near Independent Hill, VA & 135 & 2.10 & 5.30 \\
\hline 01669000 & Piscataway Creek near Tappahannock, VA & 4 & 0.56 & 0.64 \\
\hline 01673800 & Po River near Spotsylvania, VA & 19 & 0.03 & 0.08 \\
\hline 01674000 & Mattaponi River near Bowling Green, VA & 231 & 13.8 & 55.0 \\
\hline 02030000 & Hardware River below Briery Run near Scottsville, VA & 8 & 0.01 & 0.01 \\
\hline 02038850 & Holiday Creek near Andersonville, VA & 6 & 0.04 & 0.06 \\
\hline 02046000 & Stony Creek near Dinwiddie, VA & 44 & 1.72 & 4.9 \\
\hline 02047500 & Blackwater River near Dendron, VA & 45 & 29.2 & 73.0 \\
\hline 02051000 & North Meherrin River near Lunenburg, VA & 6 & 0.11 & 0.15 \\
\hline 02079640 & Allen Creek near Boydton, VA & 222 & 3.38 & 28.0 \\
\hline
\end{tabular}

appear on the web (Scott Kudlas, Virginia Department of Environmental Quality, oral commun., October 2015). During water years 1991-2013, there were 1,330 days of record with undefined $Q_{\text {prev }}$ values but with a valid previous rating; these occurred for 57 sites and include 220 discrete incidents (table 17).

A different scenario of an undefined range of a valid previous rating that also resulted in a missing $Q_{\text {prev }}$ was when flows were first measured that were either higher or lower than any previous flow. Flows higher than the maximum flow defined in previous ratings were rare and affected only 6 days of AltFlow records. One day each at three sites $(01644280$, Broad Run near Leesburg; 02040892, Appomattox River at Route 602 near Mannboro; and 02049500, Blackwater River near Franklin) and 3 days at another site (02047500, Blackwater River near Dendron, estimated values in a flood during September 1999) were adjusted to account for flows higher than previously encountered. New low flows of record were more common during the study period and affected more AltFlow record. When flows reached new lows, they typically remained low for several days. Undefined ratings caused by scour represent an important type of instability, whereas undefined ratings caused by higher or lower flows than had previously been encountered are (1) less likely to recur and (2) don't represent instability at all, just the first time a particular set of hydrologic conditions were recorded at a streamgage. There were 37 days of record at 15 sites with undefined ratings, on which flows were lower than they had been since October 1, 1990, the beginning of the study period (table 17). These seem likely to represent cases when the rating was undefined because flows reached new lows, rather than because the control scoured.

A different scenario involving undefined ratings is that, for a few sites, approved daily values were less than the minimum flow defined in the expanded shifted rating presumably used to compute the flow value (table 18). This happened on 249 days at nine sites. Nine of these 249 values were estimated, so these values may have been computed through hydrographic comparison. The other 240 values possibly were computed using stage measurements from a backup recorder outside the default DD for flow using a rating for that DD, then written as unit flow values. In any case, the 240 values do not correspond to any rating available for analysis, and their presence resulted in an error in Microsoft Excel. For all 249, $Q_{\text {prev }}$ and $Q_{\text {same }}$ were deleted from their respective rows, and comments were added explaining the deletion. 
Table 17. Number of times ratings entered ranges that had been undefined in the previous actual rating and set equal to the defined rating minimum for the purpose of this analysis, and number of days they were in such ranges for streamgages in Virginia, water years 1991-2013.

[AltFlow, alternative flow tables; $Q_{\text {prev }}$, the flow value from the shifted rating table in effect at the time of the previous flow measurement that corresponds to the gage height of each day's daily flow value; VA, Virginia; Rt, Route]

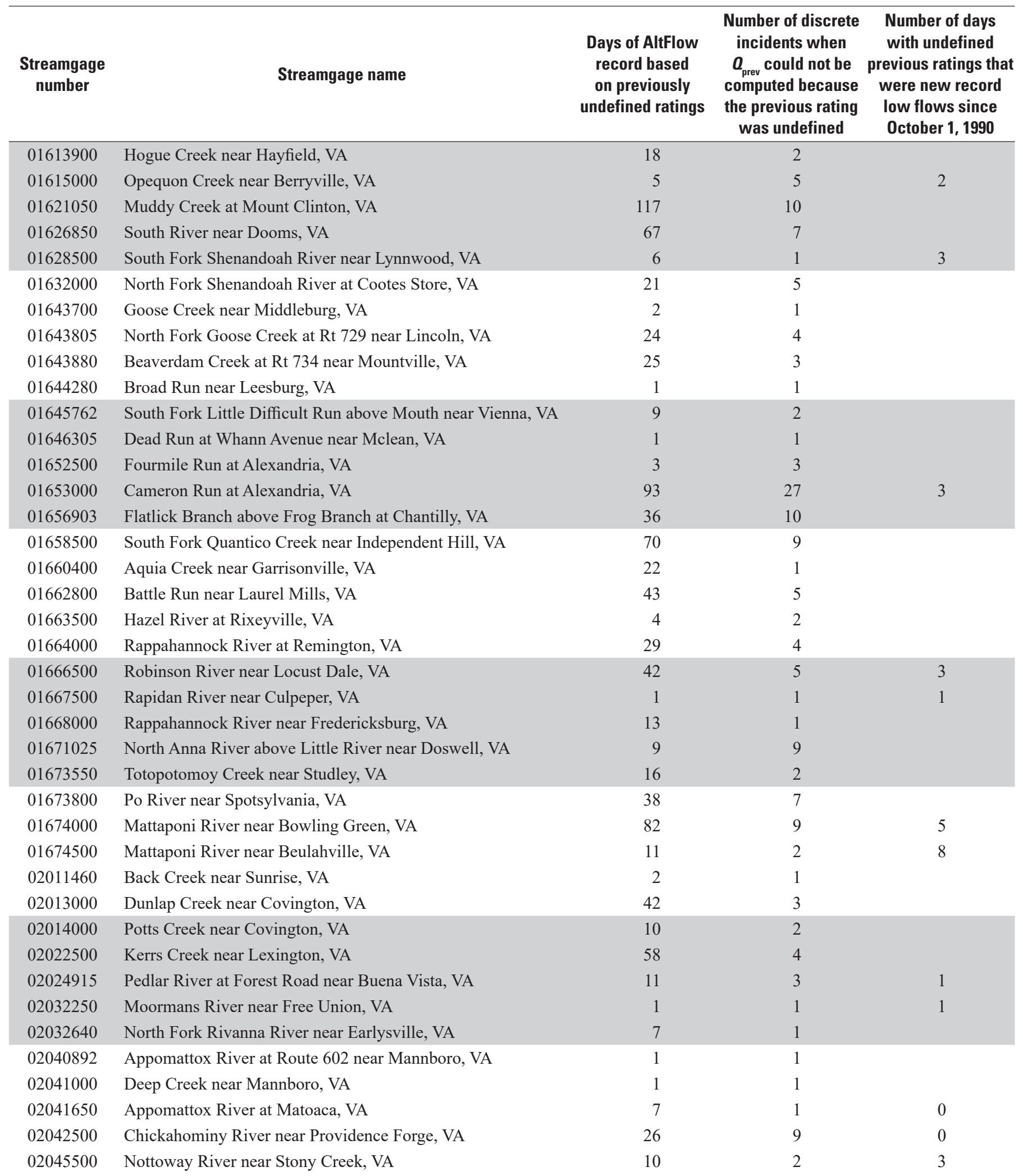


Table 17. Number of times ratings entered ranges that had been undefined in the previous actual rating and set equal to the defined rating minimum for the purpose of this analysis, and number of days they were in such ranges for streamgages in Virginia, water years 1991-2013.-Continued

[AltFlow, alternative flow tables; $Q_{\text {prev }}$, the flow value from the shifted rating table in effect at the time of the previous flow measurement that corresponds to the gage height of each day's daily flow value; VA, Virginia; Rt, Route]

\begin{tabular}{|c|c|c|c|c|}
\hline $\begin{array}{c}\text { Streamgage } \\
\text { number }\end{array}$ & Streamgage name & $\begin{array}{l}\text { Days of AltFlow } \\
\text { record based } \\
\text { on previously } \\
\text { undefined ratings }\end{array}$ & $\begin{array}{l}\text { Number of discrete } \\
\text { incidents when } \\
Q_{\text {prev }} \text { could not be } \\
\text { computed because } \\
\text { the previous rating } \\
\text { was undefined }\end{array}$ & $\begin{array}{l}\text { Number of days } \\
\text { with undefined } \\
\text { previous ratings that } \\
\text { were new record } \\
\text { low flows since } \\
\text { October 1, 1990 }\end{array}$ \\
\hline 02046000 & Stony Creek near Dinwiddie, VA & 31 & 7 & 0 \\
\hline 02047500 & Blackwater River near Dendron, VA & 41 & 4 & 0 \\
\hline 02052000 & Meherrin River at Emporia, VA & 18 & 1 & 0 \\
\hline 02061000 & Big Otter River near Bedford, VA & 10 & 1 & 1 \\
\hline 02062500 & Roanoke (Staunton) River at Brookneal, VA & 69 & 3 & 0 \\
\hline 02077000 & Banister River at Halifax, VA & 9 & 8 & 0 \\
\hline 02077500 & Hyco River near Denniston, VA & 2 & 1 & 2 \\
\hline 02079640 & Allen Creek near Boydton, VA & 1 & 1 & 0 \\
\hline 03170000 & Little River at Graysontown, VA & 10 & 1 & 0 \\
\hline 03173000 & Walker Creek at Bane, VA & 2 & 1 & 0 \\
\hline 03176500 & New River at Glen Lyn, VA & 1 & 1 & 0 \\
\hline 03177710 & Bluestone River at Falls Mills, VA & 7 & 2 & 2 \\
\hline 03207800 & Levisa Fork at Big Rock, VA & 1 & 1 & 0 \\
\hline 03208950 & Cranes Nest River near Clintwood, VA & 45 & 6 & 0 \\
\hline 03473000 & South Fork Holston River near Damascus, VA & 27 & 7 & 1 \\
\hline 03478400 & Beaver Creek at Bristol, VA & 66 & 6 & 1 \\
\hline \multirow[t]{2}{*}{03531500} & Powell River near Jonesville, VA & 6 & 1 & 0 \\
\hline & Total & 1,330 & 220 & 37 \\
\hline
\end{tabular}

Table 18. Days of approved flow record less than their respective rating minima for streamgages in Virginia, water years 1991-2013.

[VA, Virginia]

\begin{tabular}{|c|c|c|c|c|}
\hline $\begin{array}{c}\text { Streamgage } \\
\text { number }\end{array}$ & Streamgage name & $\begin{array}{c}\text { Days } \\
\text { computed }\end{array}$ & $\begin{array}{c}\text { Days } \\
\text { estimated }\end{array}$ & $\begin{array}{l}\text { Total } \\
\text { days }\end{array}$ \\
\hline 02031000 & Mechums River near White Hall, VA & 52 & 6 & 58 \\
\hline 02041000 & Deep Creek near Mannboro, VA & 1 & 0 & 1 \\
\hline 02041650 & Appomattox River at Matoaca, VA & 4 & 0 & 4 \\
\hline 02042500 & Chickahominy River near Providence Forge, VA & 18 & 0 & 18 \\
\hline 02047000 & Nottoway River near Sebrell, VA & 0 & 3 & 3 \\
\hline 02047500 & Blackwater River near Dendron, VA & 156 & 0 & 156 \\
\hline 01643700 & Goose Creek near Middleburg, VA & 5 & 0 & 5 \\
\hline 01656000 & Cedar Run near Catlett, VA & 1 & 0 & 1 \\
\hline \multirow[t]{2}{*}{03473000} & South Fork Holston River near Damascus, VA & 3 & 0 & 3 \\
\hline & Total & 240 & 9 & 249 \\
\hline
\end{tabular}




\section{Unusual Sites}

At streamgage 02037000, James River and Kanawha Canal near Richmond, VA, flow is challenging to measure using ordinary methods. The accuracy of flow records from the canal is questionable, especially low-flow records. It has a low gradient and extreme rating changes. The manuscript in Annual Water-Data Reports and Water-Year Summaries for this site includes the qualifying statement "Canal diverts from James River 1,200 ft upstream from Bosher Dam and discharges into river at several points downstream from gaging station near Richmond. Beginning with the 1969 water year, the descriptive statement that above $2,540 \mathrm{ft}^{3} / \mathrm{s}$, gage height, $14.5 \mathrm{ft}$, there is interchange of flow with the James River and that discharge above $2,540 \mathrm{ft}^{3} / \mathrm{s}$ is included in discharge for the James River near Richmond (streamgage 02037500) has been used. Daily discharges in excess of $2,540 \mathrm{ft}^{3} / \mathrm{s}$ for water years 1937-68 should be used with caution until historical records of canal construction and modifications can be reviewed. Figures given show flow in canal only" (U.S. Geological Survey, 2017).

The site 02047500, Blackwater River at Dendron, VA, is a problematic site. It is affected by variable backwater, and hydrographers described this site as subject to frequent beaver activity. Issues were exhibited through all the lines of evidence examined in this study. Measurements plotted far to the left of their ratings at irregular but recurrent intervals, indicating the effect of some type of backwater. These backwater-affected measurements generally lined up with each other as a second ghost line on the long-term rating plot. Ratings also shifted by several feet from time to time, resulting in AltFlows computed from previous ratings that were undefined on the low end one time and on the high end the next. The ratings and measurements for this site were reviewed for some sort of processing artifact during the course of this study; the review found that the ratings and measurements accurately reflected the values stored in NWIS.

The site 01671025, North Anna River above Little River near Doswell, VA, is a continuous partial-record site. At this site, flow is not computed when stage is above 12.0 feet. This results in many short gaps in the flow record and limits the number of flow statistics that can be computed from this site's record. Although this site was included in most analyses in this study, the partial nature of its record prevented it from being included in others.

\section{Comparison of Ratings and Measurements as a Check on Rating Compilation}

Comparing flow measurements to expanded shifted ratings retrieved for the time of the measurement shows how often hydrographers develop ratings within the stated guidelines (Rantz and others, 1982). For a measurement rated Good by the hydrographer, a shift or rating is to be developed within 5 percent of the measurement. For a measurement rated Fair, the rating is to be within 8 percent, and only if a measurement is rated Poor is the rating to be left with a greater than 8 percent difference. Hydrographers may also decide in the field or the office that a measurement was faulty; such a measurement may be disregarded (not used in working the record) or, in a less extreme case, effectively downgraded to Fair or Poor in the office (not given full weight). In such cases, however, appropriate remarks are to be entered into the database.

Expanded shifted ratings and the flow measurements from which they were developed were compared to each other and to the criteria used for determining whether to develop a shift (table 19, at end of report). Overall, 20,380 measurementrating pairs were compared. Measurements with negative flows were not included in this analysis, although measurements with zero flow were. For 2,482 of these, the measurement was more than 5 percent but less than 8 percent different from the rating, and for 1,063 of these, the measurement was 8 percent or greater different from the rating. The criteria of 5 and 8 percent are thresholds mandated in USGS methods manuals at which flow measurements are rated as Poor and Fair, respectively; if measurements are rated Good, the rating is to be developed or shifted to within 5 percent of the flow, if the measurement is rated Fair, the rating is to be within 8 percent, and only if a measurement is rated Poor is the rating allowed to diverge more than 8 percent from the measurement (Rantz and others, 1982; Turnipseed and Sauer, 2010).

Measurement quality assessments have always accounted for factors including flow distribution in the section, turbulence, bed roughness, changes in flow during the measurement, and equipment malfunctions. The hydrographer has always been expected to determine the departure between the measurement and the rating in the field immediately after the measurement, and to explain and document it relative to control conditions, flow measurement quality, and less frequently, stage measurement quality. In practice, problems with measurements are sometimes discovered in the office; when this happens, the database is to be updated to include remarks describing the problem.

The overall rate of unexplained measurement-rating divergence was 3.6 percent. To be counted as divergent, a measurement rated Good diverged more than 5 percent from the shifted rating or a measurement rated Fair diverged more than 8 percent from the shifted rating; measurements rated Poor were not counted. However, at seven sites, the rate of unexplained divergence was greater than 10 percent, and the maximum rate was 18 percent. For these sites, the retrievals of both ratings and measurements were checked and verified.

The percentage of unexplained measurement-rating divergence was essentially uncorrelated among sites with other stability metrics. However, several of the sites with the lowest rates of unexplained divergence were among the most stable sites as shown by $\mathrm{R}^{2}$ of GAMs or any of the AltFlow error terms (table 20, available online). One potential explanation for high rates of unexplained measurement-rating divergence at some sites could be that, if the stage record was poor at the site and large amounts of record would have to be estimated, there would be little practical reason to develop shifts at the 
site. However, it was particularly poorly correlated with percentage of estimated days $\left(\mathrm{R}^{2}=0.0085\right)$, which does not support this idea. Another possible explanation is that, at some of these sites, the daily value record itself was judged to be Fair or Poor in the qualitative assessments that are published in Annual Water-Data Report remarks for each streamgage (U.S. Geological Survey, 2016b). Although hydrographers often consider these assessments to be a major part of working a flow record, the assessments are not captured in NWIS.

\section{Examples of AltFlow Hydrographs}

All AltFlows are plotted in a series of hydrographs for the period of record in appendix 4. In total, more than 2,620 streamgage years of AltFlow record were developed at the 174 streamgages in the study (table 21, at end of report). Total length of AltFlow record ranged from 71 days through 8,387 days.

Hydrographs for four selected streamgages in the Shenandoah River Basin are shown as examples of several patterns that appear in these hydrographs (plate 3). First, although the period of record differs among streamgages, one site (01628500, South Fork Shenandoah River near Lynnwood, VA) has a nearly complete record owing to the availability of historical shifts and ratings since the 1991 water year. For the other three streamgages $(01620500$, North River near Stokesville; 01629500, South Fork Shenandoah River near Luray; and 01631000, South Fork Shenandoah River at Front Royal) AltFlow periods of record began in 2002, even though flow daily values are available continuously throughout the entire study period. All hydrographs are shown on the same time scale to simplify comparison among sites for simultaneous events. Values of $Q_{\text {same }}$ and $Q_{\text {prev }}$ are shown in units of $\log _{10}$ of flow in $\mathrm{ft}^{3} / \mathrm{s}$; negative values on the plots reflect values of flow between 0 and $1 \mathrm{ft}^{3} / \mathrm{s}$. Values of zero flow are undefinable on these plots and are shown as lines that drop to the bottom of the scale.

At all sites, $Q_{\text {same }}$ becomes available before $Q_{\text {prev }}$. Differences in $Q_{\text {same }}$ and $Q_{\text {prev }}$ are straightforward to identify as the parts of the plot where the two lines separate. At most sites, differences are greatest and most common at low or mediumlow flows. At all sites, differences are more pronounced in some years than others. At one of the sites (01620500, North River near Stokesville), $Q_{\text {prev }}$ went to zero, although $Q_{\text {same }}$ did not, indicating a fairly large change that was probably the result of scour. This same site also showed differences in $Q_{\text {same }}$ and $Q_{\text {prev }}$ at medium and high flows, which are unlikely without scour and fill on the control. In contrast, at the sites where differences appear only at low flows, the shifts and rating changes could be the result of algae and macrophyte growth or leaf accumulation. These observations are consistent with site descriptions (table 8).

Dates of measurements are shown as green dots plotted at the minimum observed value of $Q_{\text {same }}$ (plate 3 ). These are the dates when $Q_{\text {same }}$ and $Q_{\text {prev }}$ diverge from each other, or when the lines representing them cross on the plot. The AltFlow changes represent snapshots on the dates of flow measurements. Large changes, particularly at low flows at sites where shifting is caused by algae and macrophyte growth, were not necessarily as abrupt as they are depicted in these plots and were probably prorated through time from magnitudes of zero to the value that was in effect when the measurement was made. Likewise, at sites where shifting is done to account for plant growth, measurements may or may not have been made when shifts were at their maxima, and there is no particular reason to think that the AltFlows and the hydrographs derived from them capture maximum shifts very often.

\section{Stability Metrics and Their Relations to Each Other and to Basin Characteristics}

The set of AltFlow data was large and complex enough that no single metric summarized it completely. Several different summary metrics were computed, and they describe different aspects of rating stability. Additionally, other metrics of rating stability were considered, including average number of days that base ratings remained in effect, $\mathrm{R}^{2}$ from the GAM models of flow measurements, percentages of winter and total days estimated, and percentage of measurements at a site with unexplained divergence from the expanded shifted rating in effect when the measurement was made. These metrics have different strengths and weaknesses. Some of them are clearly meaningful, whereas others appear not to be. The latter group is discussed to show that the metrics were, in fact, considered and examined. Because different aspects of rating stability could be relevant to management and planning actions, overall totals of these stability metrics are compiled into a colorcoded, sortable table (table 20).

\section{Description of Stability Metrics}

Fifteen stability metrics were considered. One was derived from hydrographer stability ratings, 7 were computed from AltFlows, and 7 were computed from other data.

\section{Stability Class}

1. Stability class, as described by hydrographers, was metric 1 (table 22, at end of report); it was used for verification and as a basis of comparison for all the other metrics. Senior hydrographers participated in interviews, and later were presented with questionnaires and asked to rate the control stability for all the streamgages they personally were familiar with as Excellent, Good, Fair, or Poor. (Instructions for the questionnaire are given 
in table 23.) The descriptive evaluations were converted to numeric values of $4,3,2$, and 1 , respectively, and averaged. Ten senior hydrographers answered the questionnaire.

A total of 397 assessments were received. Considering all assessments for all sites, 32 were Excellent, 220 were Good, 109 were Fair, and 36 were Poor. Average scores for sites ranged from 1 to 4 . Most (112) sites were assessed by 2 different hydrographers; 13 sites were assessed by only 1 hydrographer, 31 were assessed by 3 hydrographers, 13 sites were assessed by 4 hydrographers, and 3 sites were assessed by 5 hydrographers. Of the 47 sites with 3 or more assessments, hydrographers came to a consensus on stability for 16 of them. Of the 112 sites with two assessments, the two hydrographers agreed for 47 of them. At 15 sites, hydrographers differed in their assessments by a full stability class, meaning that at least one hydrographer considered the site in question Excellent, and at least one other hydrographer considered it Fair, or one considered the site Good, and another considered it Poor. There were no sites that one hydrographer considered Excellent but another one considered Poor.

Hydrographers who independently evaluated the same streamgages gave them different scores and ranked them differently. Some hydrographers had more positive or negative assessments overall than others; some individuals considered

Table 23. Instructions to senior hydrographers for answering a control and rating stability questionnaire, for Virginia streamgages active September 30, 2013.

[Assessments made on the basis of these responses are given in table 22. Descriptions of control and rating stability classes are in bold type.]

The answers for this questionnaire are to be used to classify selected streamgages in Virginia on the basis of overall control stability and rating quality, particularly with respect to how reliable provisional data are in real time and how likely provisional data are to match final data at each site. Please consider factors including frequency of shifting, magnitude of shifts or rating changes needed, predictability of changes, duration of stable periods, quality of the measuring section, site characteristics that affect the completeness and quality of stage data, or anything else that affects the likelihood of changes from provisional data to final data.

Please provide an answer for each streamgage that you're familiar with, and skip streamgages you're not familiar with. Because several stream characteristics of interest are related to location, some field offices will have many good or excellent sites and few fair or poor sites, while other field offices will have many fair or poor sites and few good or excellent sites. There is no particular reason that the overall network would be divided equally into excellent, good, fair, and poor sites, so don't worry about having more in one category than another. Different people have different expectations for excellent, good, fair, and poor sites, but because common criteria are desirable for this questionnaire, please consider the following criteria.

An excellent site is one where the base rating is well defined, may remain stable for years, and is only likely to change in response to a major event. Shifts are small and are made in response to predictable seasonal factors. Scour and fill on the control is rare or minor. Some record may be affected by ice, but if so, it is easy to identify in real time.
A good site is one where the base rating is well defined, but it may change every few years. It might be subject to regular seasonal shifting because of weeds, algae, or leaves, but the shifts are moderate, predictable, and practical to define. Alternately, it might have occasional or moderate scour-fill shifting.
A fair site is one where the rating changes fairly frequently. The control may have fairly large weed or leaf shifts, which may sometimes be difficult to characterize throughout the full range of stage. It may have substantial scour-fill shifting, or scour and fill of the control occasionally may be large. The stream bank may only be moderately stable, and occasionally a tree or other obstruction may catch on the control. Beavers may occasionally be present, but they do not tend to build dams on the gage control very often.
A poor site may be one where the control changes constantly. The base rating may not be practical to define because of frequent changes to the control. Alternately, the control may not change extraordinarily often, but the changes are large and unpredictable. The control may scour and fill multiple times between visits. Banks may be highly unstable, and this may result in logs catching on the control frequently and washing off between visits. The timing of these events may be difficult to determine after the fact. Beavers may build dams on the control frequently. 
most of the controls to be Fair or Poor and few to be Excellent, whereas others considered many of their controls to be Good or Fair and few to be Poor.

Some of the inconsistency of evaluations was likely the result of changes to streams through time; individuals who worked at the same streamgages at different times experienced different conditions and were left with different impressions. Another cause of inconsistent evaluations was lack of a common frame of reference. No individual hydrographer in Virginia claimed to be familiar with every streamgage in the network. Of the 174 streamgages included in this study, the most that any individual evaluated was 100 . However, as shown by the lack of agreement on stability of controls rated by more than one hydrographer, different individuals, even experts, are prone to make subjective assessments differently.

Despite these weaknesses, this metric alone might be acceptable for certain applications, such as internal allocation of workload within a field office. It was used as verification for the quantitative metrics discussed below. Consistency in subjective assessments of the stability of controls is not essential to consistent computation of flow data, which instead requires consistent responses to measured changes regardless of whether or not a particular streambed is stable.

\section{Metrics Derived from AltFlows}

The AltFlow tables are summarized using seven different stability metrics.

2. The average of daily percent errors, or

$$
\frac{\sum_{i}^{n} \frac{Q_{\text {prev }}-Q_{\text {same }}}{Q_{\text {same }}}}{n} .
$$

This method for computing percent error works well for datasets with small error terms. However, it is problematic when error as a percentage of $Q_{\text {same }}$ is relatively large. Error terms have larger magnitudes when $Q_{\text {same }}$ is greater than $(>) Q_{\text {prev }}$ than when $Q_{\text {prev }}>Q_{\text {same }}$. This is because the magnitude of error as a percentage of $Q_{\text {same }}$ is asymptotic as it approaches 100 percent when $Q_{\text {same }}>Q_{\text {prev }}$ but unlimited when $Q_{\text {prev }}>Q_{\text {same }}$. When the difference between $Q_{\text {prev }}$ and $Q_{\text {same }}$ exceeds the magnitude of flow, daily percent error is wildly different, depending on whether $Q_{\text {prev }}>Q_{\text {same }}$ or $Q_{\text {same }}>Q_{\text {prev }}$. When these values are averaged together, values for days when $Q_{\text {same }}>Q_{\text {prev }}$ dominate values when $Q_{\text {prev }}>Q_{\text {same }}$. Rating changes that exceed the magnitude of flow are not especially common overall (they represent 1.3 percent of observations in the overall dataset), but they are common at some sites (table 20). At streamgage 02037000, James River and Kanawha Canal near Richmond, VA, the absolute value of $Q_{\text {prev }}-Q_{\text {same }}$ exceeded that day's $Q_{\text {same }}$ on 21.5 percent of days, and at streamgage 01646305 ,
Dead Run at Whann Avenue near McLean, VA, the absolute value of $Q_{\text {prev }}-Q_{\text {same }}$ exceeded that day's $Q_{\text {same }}$ on 19.5 percent of days. Three more sites had differences exceeding $Q_{\text {same }}$ more than 10 percent of the time, and 11 sites had differences exceeding $Q_{\text {same }}$ between 5 and 10 percent of the time. Similar but nonidentical patterns were present when error was compared to $Q_{\text {prev }}$. The same two sites (02037000 and 01646305) had the highest percentages of difference exceeding flow and had more than 10 percent of days when difference exceeded flow. Nine instead of 11 sites had between 5 and 10 percent of days when differences exceeded $Q_{\text {prev }}$.

Another, albeit smaller, problem with the average of daily errors as a metric is that, when the value of $Q_{\text {same }}$ is zero but flow is indicated for $Q_{\text {prev }}$, values for error expressed as a percent of $Q_{\text {same }}$ are undefined. This happened at 13 sites in the network and affected 697 days of record (table 15). Forty-two percent of these days came at one site, 02037000, James River and Kanawha Canal near Richmond, VA. The largest of these non-zero values of $Q_{\text {prev }}$ on days with $Q_{\text {same }}$ of 0.00 were also observed at this site; mean and maximum were 136 and $643 \mathrm{ft}^{3} / \mathrm{s}$, respectively. At the other sites on days with $Q_{\text {same }}$ of 0.00 but non-zero values of $Q_{\text {prev }}$, mean values of $Q_{\text {prev }}$ by site ranged from 0.01 to $16.9 \mathrm{ft}^{3} / \mathrm{s}$, and maximums ranged from 0.01 to $19 \mathrm{ft}^{3} / \mathrm{s}$. For purposes of computing mean percentage error, these values were excluded, but as these values all, by definition, came at low flow, their exclusion removed valuable information from the analysis.

Problems with computation aside, this metric (average of daily percent errors) is highly sensitive to changes in ratings that affect low flows, especially the lowest flows. Differences in the lowest flows tend to be small in magnitude but high in percentage. Depending on the users' priorities and needs, this sensitivity could be useful or problematic. It is presented by month and flow percentile in table 24 (available online) and in total for each site in table 20 .

\section{3. $\Sigma$ Error $/ \Sigma Q$}

This is a flow-weighted average of error. Positive and negative errors cancel each other out when added together so that cyclic or fluctuating rating changes, such as those caused by algae or macrophyte growth and death, leaf accumulation and removal, or scour and fill, tend to cancel each other out. To the extent that such changes are predictable, then, this metric might filter them out and quantify unpredictable rating changes. This tendency may be more meaningful for periods of 1 or 2 years than for the entire period of record. Over the entire period of record, the metric is potentially useful for determining whether a rating has changed more in one direction than another, as in the case of a stream 
that has been downcutting or aggrading at a control; however, this type of change is more readily identifiable through the time-series plots of measurement residuals. It is presented in total for each site (table 20), but a more detailed table of this metric is not presented.

\section{4. $\Sigma \mid$ Error $\mid / \Sigma Q$}

This is a flow-weighted average of absolute error. One bias is that cyclic or fluctuating rating changes, such as those caused by algae or macrophyte growth and death, leaf accumulation and removal, or scour and fill, are counted (1) when they form and (2) when they dissipate. It is also sensitive to rating changes that affect high flows and therefore result in large changes in flow magnitude. It is presented in total for each site (table 20), but a detailed table of this metric is not presented.

5. RMSE on log-transformed flow values

When flow data are log-transformed and RMSE is computed on the transformed data, the result is an error term that weighs errors throughout the range of flows more equally than one computed on untransformed data. One shortcoming of this is that values of zero flow, whether for $Q_{\text {prev }}$ or $Q_{\text {same }}$, are undefinable for log-transformation. When both $Q_{\text {prev }}$ and $Q_{\text {same }}$ were equal to zero, the error term was manually set equal to zero, and the day's record was included in summary tables. RMSE is presented by month and flow percentile (table 25 , available online), and in total for each site (table 20).

6. Percentage of days with zero difference between $Q_{\text {same }}$ and $Q_{\text {prev }}$

A day with no difference in flow between $Q_{\text {same }}$ and $Q_{\text {prev }}$ represents a point on the rating that remained the same from one visit to the next. Unlike the other stability metrics that reflect magnitude of rating change, a percentage of zero difference treats all rating changes the same. This metric therefore is not affected by whether the rating changed at high or low flow. Unlike the metrics that incorporate flow magnitude, it is not unduly affected by infrequent large changes such as those resulting from beaver dams, swimmers' dams, or human activity at otherwise stable sites; these are changes that in practice would be noticed quickly by hydrographers and waterdata users.

Total percentage of zero-difference days ranged from about 15 percent $(0165389205$, Accotink Creek near Ranger Road at Fairfax, which has since been discontinued) to about 89 percent (02011800, Jackson River below Gathright Dam near Hot Springs, and 02011490, Little Back Creek near Sunrise; table 20). All the sites with low percentages of zero-difference days ( $<40$ percent) were on small streams $\left(<100-\mathrm{mi}^{2}\right.$ drainage area) in northern Virginia or in other parts of Virginia with elevation less than 500 feet, or both. Of the 31 sites with less than 40 percent of zero difference days, only 6 sites drained more than $100 \mathrm{mi}^{2}$, and only 3 sites were at elevations above $500 \mathrm{ft}$. In contrast, of the 30 sites where more than two-thirds of the days had zero difference, all but 4 sites were on large streams $\left(>500 \mathrm{mi}^{2}\right.$ drainage area) or at elevations of more than $1,000 \mathrm{ft}$, or both; 1 of the 4 sites has a bedrock control. There were many small, high-elevation sites and several large, low-elevation sites with low or medium percentages of zero difference.

The percentage of AltFlows with zero difference between $Q_{\text {prev }}$ and $Q_{\text {same }}$ for each streamgage in the study is shown, by month, in table 26 (available online). When zoomed out so that the entire table is visible, it displays the entire AltFlow dataset. By default, sites (rows) are sorted by downstream order number, so that they are grouped by basin. Each column represents a month. Green cells signify no or few nonzero differences between $Q_{\text {prev }}$ and $Q_{\text {same }}$; stated differently, they signify little or no change in the rating from measurement to measurement. Red cells signify many nonzero differences between $Q_{\text {prev }}$ and $Q_{\text {same }}$ or that the rating changed between the most recent measurement and the previous measurement. While fully zoomed out, of course, dates, site identifiers, and values are illegible; the table is intended to be used interactively onscreen, zooming out to see broad patterns and zooming in to see detail.

7. Percentage of days when the difference between $Q_{\text {same }}$ and $Q_{\text {prev }}$ exceeded $Q_{\text {same }}$

Essentially the opposite of the percentage of days with zero difference, this metric considers only large rating changes, those resulting in flow differences of 100 percent or more (table 20). Such changes existed at 90 of the sites. At 84 of the sites, this never happened, and at another 37 of the sites, it happened less than 1 percent of the time.

In order for the difference between $Q_{\text {prev }}$ and $Q_{\text {same }}$ to exceed $Q_{\text {same }}, Q_{\text {prev }}$ must exceed $Q_{\text {same }}$. This is caused by changes to the control that increase backwater, such as fill, macrophyte and algae growth, leaf accumulation, and deposition of logs and other woody debris. These changes are much more common at low flow than high flow; almost one-half of these were days when $Q_{\text {same }}$ was less than the D90 (90 percent duration flow; 5,693 days of 12,794), and about 93 percent of them were days when $Q_{\text {same }}$ was less than the D50 (50 percent duration flow; 11,913 days of 12,794). Beaver dams, swimmers' dams, or large logs on the control are among the likeliest types of obstructions that might cause backwater at medium or high flows. At low flow, small absolute changes to the control can result in large relative changes 
to the rating, and the majority of the days when the difference between $Q_{\text {prev }}$ and $Q_{\text {same }}$ exceeded $Q_{\text {same }}$ were during the time when medium to low flow is typical. Among all sites, 10,280 days of 12,794 were during July through December, and September was the month with the largest number of these days $(2,084)$.

At 30 of the sites where the difference between $Q_{\text {prev }}$ and $Q_{\text {same }}$ exceeded $Q_{\text {same }}$, the difference between $Q_{\text {same }}$ and $Q_{\text {prev }}$ exceeded $Q_{\text {same }}$ more than 2.5 percent of the time, or about 9 days per year. These 30 sites with the highest rates of large changes are predominantly either (1) small in area - the largest drainage area among them is $332 \mathrm{mi}^{2}$, (2) low in elevation-only 4 of them are at elevations greater than $1,000 \mathrm{ft}$, or (3) both. Seven of the sites drain more than $100 \mathrm{mi}^{2}$, and 6 of them are at elevations below $500 \mathrm{ft}$. Three of the 4 sites above $1,000 \mathrm{ft}$ drain less than $20 \mathrm{mi}^{2}$. One site $(01632000$, North Fork Shenandoah River at Cootes Store) is neither low nor especially small; it is at an elevation of $1,051 \mathrm{ft}$ and drains $210 \mathrm{mi}^{2}$. There, the difference between $Q_{\text {prev }}$ and $Q_{\text {same }}$ exceeded $Q_{\text {same }} 2.8$ percent of the time. This site was an outlier in several other stability metrics.

Of the 84 sites where the difference between $Q_{\text {prev }}$ and $Q_{\text {same }}$ never exceeded $Q_{\text {same }}$, most are on large streams or at high elevations. Forty-three sites are at elevations greater than $1,000 \mathrm{ft}$, and 29 drain more than $500 \mathrm{mi}^{2}$. Only 4 are at elevations less than $500 \mathrm{ft}$ and drain less than $200 \mathrm{mi}^{2}$; 1 of the 4 had only 2 years of record, which may or may not have been representative of longterm conditions.

8. Percentage of days when the difference between $Q_{\text {same }}$ and $Q_{\text {prev }}$ exceeded $Q_{\text {prev }}$

At 94 streamgages, the difference between $Q_{\text {same }}$ and $Q_{\text {prev }}$ exceeded $Q_{\text {prev }}$ at least one time; at the other 80 , this never happened (table 20). Patterns between this metric and metric 6 were generally similar. Sixty of the sites had non-zero values for both, whereas at 73 sites, the difference between $Q_{\text {same }}$ and $Q_{\text {prev }}$ never exceeded either $Q_{\text {same }}$ or $Q_{\text {prev }}{ }^{\circ}$

In order for the difference between $Q_{\text {prev }}$ and $Q_{\text {same }}$ to exceed $Q_{\text {prev }}, Q_{\text {same }}$ must exceed $Q_{\text {prev }}$. This is caused by scour and other changes to the control that increase flow relative to stage, such as removal of macrophytes and algae or the washing away of leaves, logs, and other woody debris. The changes to the control are likely to result from peaks or high flow pulses but are more likely to affect low flows than high flows. About one-fourth of the days with $Q_{\text {prev }}-Q_{\text {same }}>Q_{\text {prev }}$ came when $Q_{\text {same }}$ was less than the D90 $(3,241$ days of 12,394$)$, and about three-fourths of them came when $Q_{\text {same }}$ exceeded the D50 $(9,616$ days of 12,394$)$. Seasonality was less pronounced than it was for metric 7. Days when $Q_{\text {prev }}-Q_{\text {same }}>Q_{\text {prev }}$ were somewhat less frequent in spring than other seasons (2,938 days of 12,394 during March through June), but those days were generally fairly evenly distributed throughout the year.

Although the overall patterns were similar, this metric did not correlate as strongly with metric 7 as one might expect; rho was only 0.8772 . This metric may be different because at some sites, scour is abrupt and fill is gradual, and at others, vice versa. Another possibility is that at some sites, algae and macrophyte growth or leaf accumulation are gradual, but dissipation is abrupt and often accompanied by scour. It is also possible that the two metrics are showing more or less the same thing. The correlation between them might be low despite the metrics showing the same thing because of the large number of near-zero observations from each metric that correspond with a zero observation for the other. Most likely, the two metrics are showing the same thing, but the metrics are affected principally by infrequent events and are therefore insensitive and imprecise.

\section{Other Metrics}

Seven additional metrics, 9-15, were considered.

9. Proportion of daily values that were estimated

This was one of the simplest metrics to compute and was determined from the series of daily values $\left(Q_{\text {meas }}\right)$ itself; it was just the number of days per site with a remark code of "A:e" (table 13) divided by total days of record, computed for the period when AltFlows were available for each site (table 20). Total estimated daily values are most affected by issues with the stage record, including recurring problems with sedimentation related to the location of the stilling-well intake or bubbler orifice, isolated problems with equipment failure, and in winter, ice effect. At one site, the stream downcut at the control and left the stilling-well intakes out of the water for several days. Strictly speaking, this metric was not thought to be directly related to rating stability. This relation was investigated because sediment deposition is related to scour-and-fill shifting and to many problems with stilling-well intakes and bubble-gage orifices.

10. Proportion of daily values in winter that were estimated

The three months with the highest rates of estimated record were, in order, January, February, and December. Although intakes and orifices may be plugged during winter, and equipment failure is more common during winter than the rest of the year, the great majority of estimated days in winter are likely caused by ice effects. Ice effects may take the form of anchor ice accumulating on the control, a total freeze over of a stream, and less 
commonly, ice jams. All of these can result in backwater in the gaging pool, which makes the stage-flow relation invalid until the ice melts or washes out. Since flow cannot be computed with the rating during these periods, it is estimated as mean daily flow. Like total estimated daily values, winter estimates should not, strictly speaking, be related to control and rating stability. This metric is presented in total by site in table 20 .

11. Average days that base ratings were in effect

The average number of days that base ratings were in effect at each site might seem to be a useful stability metric. However, it was almost completely uncorrelated with other metrics $\left(\mathrm{R}^{2}=0.0069\right.$ with percent zero difference and 0.0451 with total RMSE for AltFlows), highly affected by differences among field offices and individual hydrographer's preference, and affected by length of record at the streamgages. This metric is presented by site in table 20 .

12. $\mathrm{R}^{2}$ of most recent $\mathrm{GAM}_{\mathrm{Q}}$ model

Many of the sites had multiple rating families, as described in previous sections of this report. Only the most recent rating family was included and is presented by site (table 20). GAM models were fit to gage height and flow from flow measurements; this was one of the three error terms from these models that was considered to be a candidate stability metric.

13. $\mathrm{R}^{2}$ of most recent $\mathrm{GAM}_{\mathrm{GH}}$ model

This is the second of three potential stability metrics derived from the analysis of variability of flow measurements; it was derived from GAM models that fit gage height as a smoothing function of flow. It was considered but rejected as a candidate stability metric. Its correlation with the other metrics was investigated. It is presented by site for the most recent rating family (table 20).

14. Spearman's rho of the most recent rating family

This was the third of three potential stability metrics derived from analysis of variability of flow measurements subset by rating family. Unlike the other two, it had nothing to do with the GAM models, and as a rankbased statistic, it would be exactly the same regardless of which variable was considered to be dependent. It was considered but rejected as a candidate stability metric. Its correlation with the other metrics was investigated. It is presented, by site, for all rating families (table 13).

15. Percentages of measurements with unexplained divergence from the rating

Described previously, the rate of unexplained divergence from the rating was lowest at some sites described as having stable ratings and excellent stage record. It was considered but rejected as a candidate stability metric. Its correlation with the other metrics was investigated. It is presented by site, for the most recent rating family (table 20).

\section{Relations Among Stability Metrics}

Relations among stability metrics were investigated using three types of analysis. Spearman's rho correlation coefficients were determined among sites for all pairs of metrics and are presented in table 27, sorted by strength of correlation with stability class. Spearman's rho was chosen because the stability metrics had different frequency distributions and a rankbased statistic eliminated the need to transform them. The stability classes were assigned numeric values of 1, 2, 3, and 4, corresponding to Poor, Fair, Good, and Excellent, respectively, for purposes of computing the correlations. The correlations between stability class and the quantitative metrics were weak. No correlation had an absolute value greater than 0.5 . The six metrics most strongly correlated with stability class were all derived from AltFlows; these were AltFlow absolute error divided by flow, difference $>Q_{\text {same }}$, RMSE, difference $>Q_{\text {prev }}$, percentage of average daily error, and percentage of zero difference of AltFlows. The $\mathrm{R}^{2}$ of $\mathrm{GAM}_{\mathrm{Q}}$ was next; no other metric had a rho with an absolute value greater than 0.3 . These correlations are illustrated using a scatterplot matrix (plate 4).

Correlations among most of the error terms derived from AltFlows were generally the strongest of the entire set. As an example, the magnitude of Spearman's rho between AltFlow RMSE and 5 of the other 6 such terms ranged from 0.75 to 0.90 .

The percentage of AltFlow daily error averaged was surprisingly strongly correlated with stability class $(-0.4248)$ and some other metrics ( $|\mathrm{rho}|>0.6$ for four other metrics), considering the problematic nature of its computation as discussed in its description (section "Metrics Derived from AltFlows"). Percentage of daily error averaged seems to be sensitive to relatively large differences in low flows, and if no other metrics sensitive to differences at low flow were available, it might be worth retaining despite problematic computation. However, AltFlow RMSE is only moderately affected by large-magnitude rating changes because it is computed and reported in log space. Percentage of zero-difference days is indifferent to flow magnitude, but the two metrics, based on differences exceeding magnitude of flow, are dominated by rating changes at low flow. In light of this, percentage of daily error averaged is probably too problematic a metric to consider as meaningful, although it is retained in this report for the purposes of documenting how it was considered.

Another candidate metric derived from AltFlows that is not clearly meaningful is the sum of error divided by the sum of flow. Its strongest correlation with any other proposed stability metric was -0.3248 with percentage of daily error 


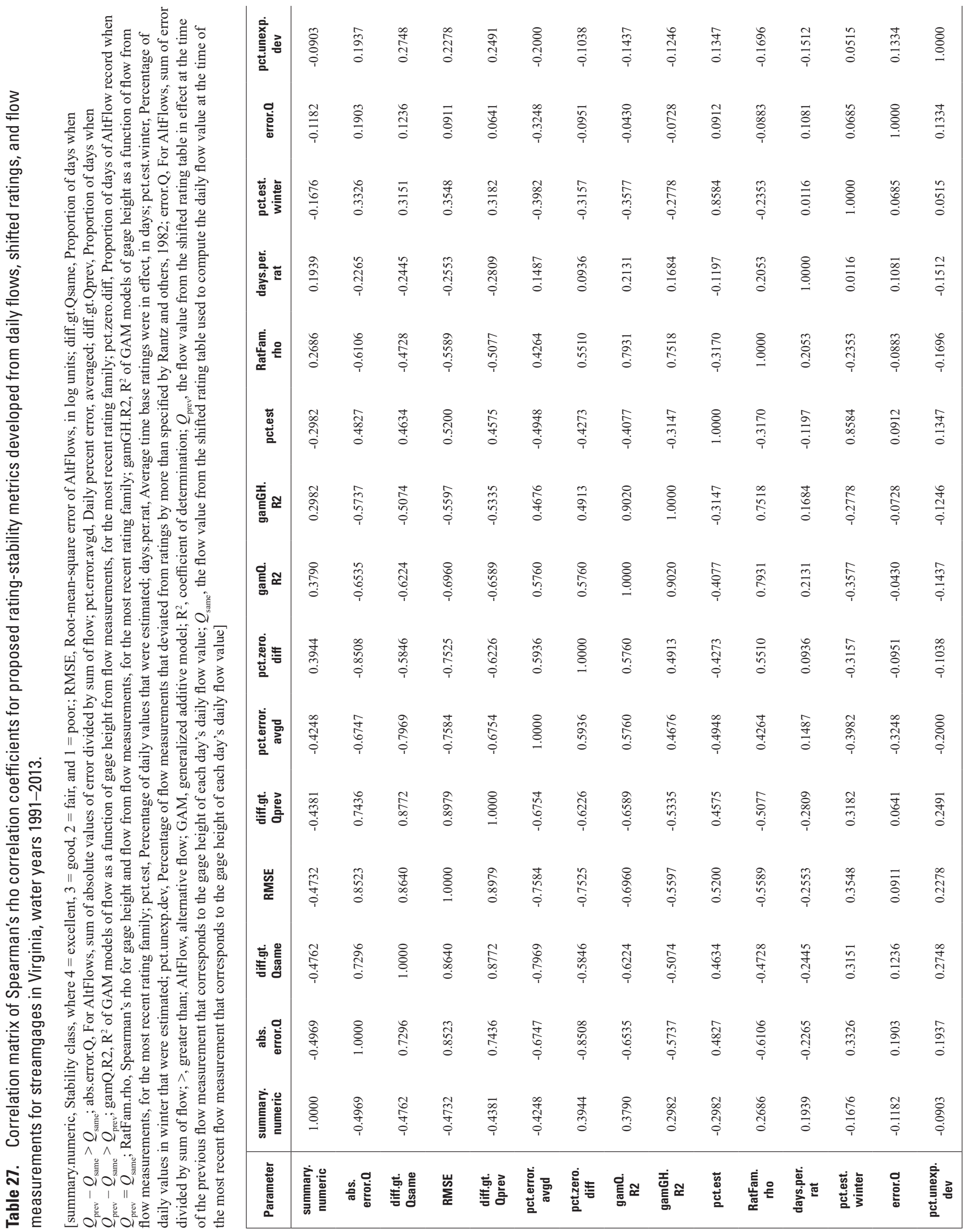


averaged. The weakness of correlation between this metric and the others is likely due to positive and negative errors canceling each other out.

Two other proposed stability metrics that correlated only weakly with any other metric, including stability class, were percentage of flow measurements with unexplained deviation from the rating and length of time that base ratings were in effect. The length of time for base ratings to remain in effect would at first seem to be an obvious metric for rating stability, if not the most obvious imaginable. That it is at most weakly correlated with other stability metrics is a result of the role of hydrographer preference in achieving the same final expanded shifted rating tables through different combinations of ratings and shifts. The percentage of measurements with unexplained deviation from the rating is not such an obvious candidate for a stability metric. It emerged as a candidate metric during data exploration and seemed promising enough to include for this level of screening; it is apparently fairly arbitrary.

The two candidate metrics based on percentages of estimates were strongly correlated to each other $($ rho $=0.8584)$. This is reasonable because a disproportionate amount of estimated daily flow values comes in the winter. Both metrics were weakly correlated with stability class, -0.2982 for total estimates and -0.1676 for winter estimates. Total estimates were moderately correlated with $\mathrm{R}^{2}$ of $\mathrm{GAM}_{\mathrm{Q}}$ and several of the AltFlow-derived metrics, with the absolute value of rho as high as 0.5200 for RMSE and greater than 0.4 for six of the other metrics. Winter estimates had a weaker correlation with each of the other candidate metrics than did total estimates. Although these two candidate metrics are, as expected, weakly correlated with measures that are truly reflective of a streamgage's stage-flow relation, they still provide valuable information on the reliability of a streamgage in real time and are retained for further analysis.

The comparisons among rating-stability metrics included comparisons of error terms for different GAM models that were used to select the $\mathrm{R}^{2}$ of $\mathrm{GAM}_{\mathrm{Q}}$ as the preferred model for fitting flow and gage height from measurements. Of these error terms, the $\mathrm{R}^{2}$ of $\mathrm{GAM}_{\mathrm{Q}}$ is the most strongly correlated of the rating family metrics not only to stability class, but to all except two of the other proposed metrics. Those two were metrics that have already been rejected as not being meaningful are the percentage of unexplained deviation between measurements and ratings and the sum of AltFlow error divided by sum of flow. Considering the strength of its relations to other metrics, $R^{2}$ of $\mathrm{GAM}_{\mathrm{Q}}$ was judged to be the strongest of the three rating family metrics under consideration.

Other stability metrics could have been developed from the set of data derived from measurements alone if the AltFlows had not been available. For instance, the residuals could have been sorted by time, and the number of them that exceeded or failed to exceed meaningful thresholds could have been counted either in total or in series. Change from measurement to measurement could also have been computed. Such metrics were not explored in this study, although they may have been meaningful, because AltFlows were available. Change from measurement to measurement and residuals would be considerably easier to compute because data acquisition and management would have been much simpler.

Another type of analysis of these candidate metrics is a series of boxplots for each metric, by stability class (fig. 8). Boxplots serve as a summary and check on the correlation analysis. They show strong separation between classes, defined as the 75th percentile exceeding the median from class to class and the median exceeding the 25 th percentile from class to class, for only one candidate metric, sum of absolute error divided by sum of flow. Little or no separation between classes is visible for total estimates, winter estimates, AltFlow sum of error divided by sum of flow, base rating length, and percentage of unexplained deviation between measurements and ratings. Boxplots of the remaining metrics all show the expected patterns among classes but moderate or mixed separation among classes.

$Q_{\text {prev }}-Q_{\text {same }}>Q_{\text {same }}$ shows a stronger correlation with stability class than does $Q_{\text {prev }}-Q_{\text {same }}>Q_{\text {prev }}$, and the boxplots of the former show a greater separation by stability class than those of the latter. The two metrics are strongly, if not perfectly, correlated with each other $($ rho $=0.8772)$, and they are likely to be providing largely the same information in an imprecise way. Of the two metrics, $Q_{\text {prev }}-Q_{\text {same }}>Q_{\text {same }}$ was selected as the metric that provided a greater separation of values.

On the basis of this comparison, seven stability metrics were considered to be meaningful and were retained for comparison to site and basin characteristics. Total RMSE between log-transformed $Q_{\text {prev }}$ and $Q_{\text {same }}$ is affected by the magnitude and frequency of rating changes, and the transformation weights change throughout the range of flows so that none of high, medium, or low flows dominate the statistic. Days when $Q_{\text {prev }}-Q_{\text {same }}>Q_{\text {same }}$ is a measure of relatively large rating changes, most of which come at low flow. The sum of absolute AltFlow error divided by total flow is a flow-weighted statistic that is strongly affected by large-magnitude rating changes, which are predominantly at the high end of the rating; this metric is useful in evaluating rating stability relative to total volume of water during a period of time. The $\mathrm{R}^{2}$ of GAM $\mathrm{Q}$ is computed from flow measurements, not rating changes, and as such, was fast and easy to compute. Because most of the scatter on the GAM graphs is at the low end, $\mathrm{R}^{2}$ of $\mathrm{GAM}_{\mathrm{O}}$ is most sensitive to variability at the low end of ratings. Unlike the various AltFlow metrics, $\mathrm{R}^{2}$ of $\mathrm{GAM}_{\mathrm{Q}}$ is independent of time, and unlike most of them, its magnitude is independent of the flow magnitude of the individual error. Percentage of days with zero difference between $Q_{\text {prev }}$ and $Q_{\text {same }}$ is a measure of the frequency of rating change. Percentage of total estimated days and percentage of estimated days in the winter are weakly related to control stability, if they are related to it at all, but provide information on the overall quality of the flow record and on the historical likelihood that winter record was affected by ice. 

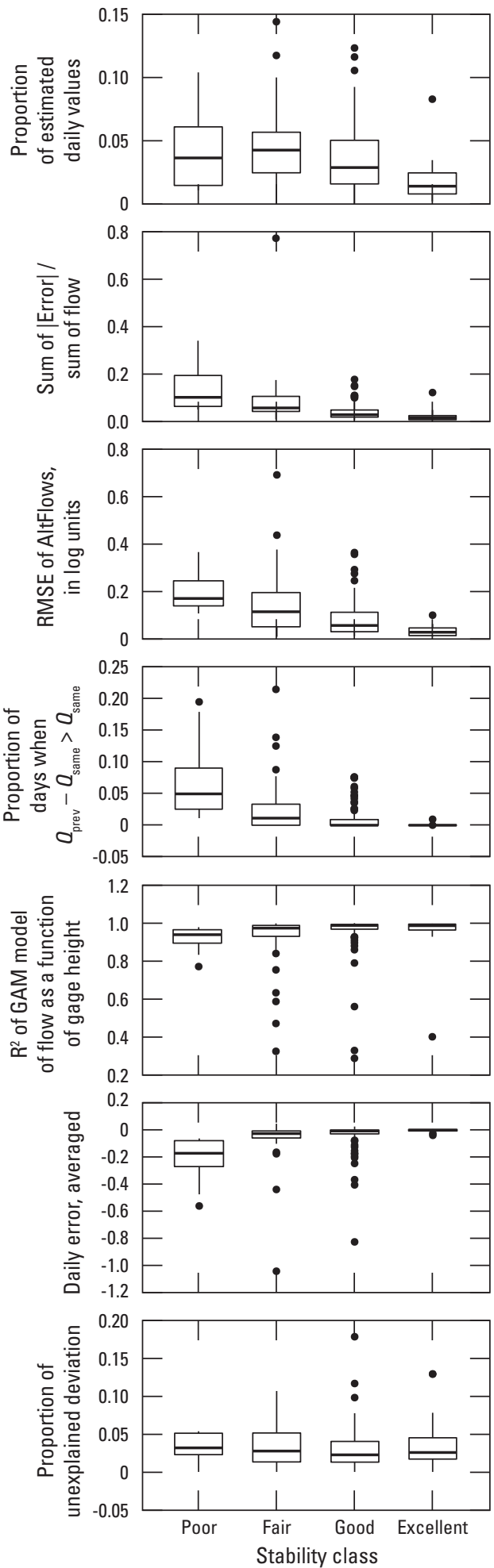
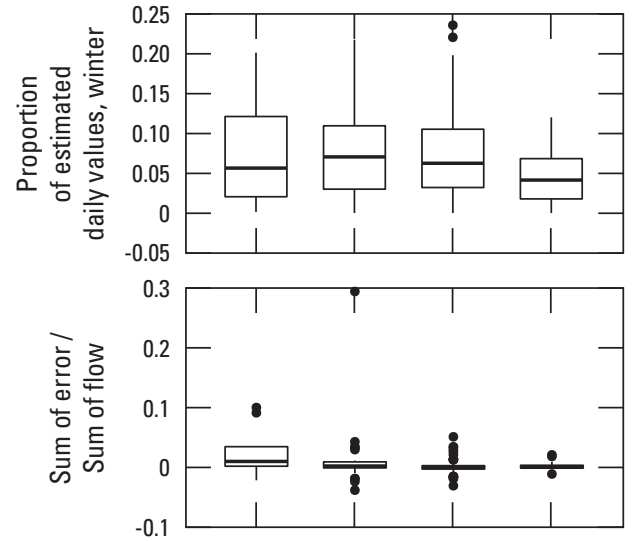

- Outlier

The largest value that does not exceed the 75th percentile plus 1.5 times the interquartile range

75th percentile

Median

25th percentile

The smallest value that does not exceed the 25th percentile minus 1.5 times the interquartile range
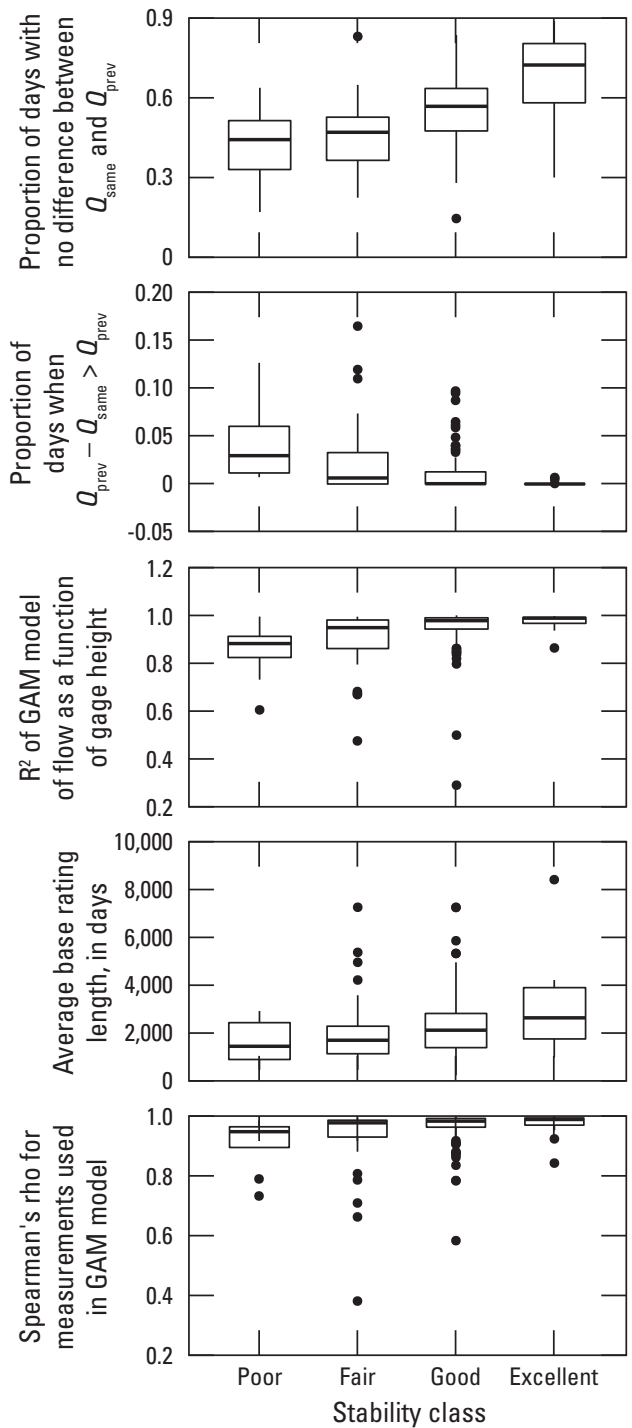

Figure 8. Distribution of proposed stage-flow relation stability and real-time flow reliability metrics by descriptive stability class for streamgages in Virginia active on September 30, 2013. (GAM, generalized additive model; R2, coefficient of determination; $Q_{\text {prev' }}$ the flow value from the shifted rating table in effect at the time of the previous flow measurement that corresponds to the gage height of each day's daily flow value; $Q_{\text {same }}$ the flow value from the shifted rating table used to compute the daily flow value at the time of the most recent flow measurement that corresponds to the gage height of each day's daily flow value) 


\section{Stability Metrics and their Relations to Site and Basin Characteristics}

Stepwise multiple regression analysis was done to determine whether relations among the various stability metrics and quantitative basin and site characteristics could be determined. These relations are weak, and the results of the regression models were not meaningful. The basin characteristics are those used in Virginia's most recent low-flow frequency report (Austin and others, 2011; https:/pubs.usgs.gov/sir/2011/5143/ tables/Table_09.xlsx). For four stability metrics (percentage of zero difference days, total site AltFlow RMSE, $\mathrm{R}^{2}$ of the GAM models for the most recent rating family at each site, and days when $Q_{\text {prev }}-Q_{\text {same }}>Q_{\text {same }}$, regression models developed using stepwise regression had low multiple $\mathrm{R}^{2}$ values, ranging from 0.3599 to 0.5542 , even though the models included between 7 and 16 independent variables. Stepwise regression is controversial and is criticized when it is used to develop overfitted models that by coincidence have good error terms but prove not to be reproducible. In this case, however, the error terms were poor, indicating weak relations between stability metrics and basin characteristics, which is not a commonly criticized outcome for stepwise regression. Variables representing basin size, elevation, location (latitude and longitude), multiple physiography terms, and multiple impervious surface terms were identified as being weakly related to more than one stability term.

Review of scatterplot and correlation matrices also indicated few strong correlations between stability terms and basin characteristics (plate 5; table 28). The strongest correlation (Spearman's rho) between any stability metric and basin characteristic was -0.6655 , between percentage of days when $Q_{\text {same }}-Q_{\text {prev }}>Q_{\text {same }}$ and longitude; in this case, large rating changes were common in eastern Virginia and rare or nonexistent in western Virginia. Weak correlations are to be expected with a dataset characterized by threshold effects and where many of the metrics under analysis include a high proportion of values that are similar. Highly local conditions, the configuration and composition of the streambed at a single cross section, are of the greatest importance to control and rating stability. Favorable local conditions may be found in isolation even in areas where stream conditions are generally unfavorable for streamgaging. Because only a single favorable cross section is needed for each streamgage, favorable conditions may be found or created in most streams where data are needed.

Relations between channel characteristics at high, medium, and low flows and stability metrics were explored. Cross-sectional area, stream depth, width, and velocity were determined for D1, D50, and D90 for the sites in the study from relations between these characteristics and flow in the flow measurement dataset. These values were then used to generate power curves against drainage area, and residuals for all these power curves were captured and included in exploratory analysis. Width-to-depth ratios were also determined for D1, D50, and D90. Scatterplot matrices were constructed, and Spearman's rho correlation coefficients were determined among all the stability metrics and channel characteristics. The strongest relations were slightly stronger than those between stability metrics and basin characteristics but were still too weak to use for screening candidate streamgage locations or other actions. The maximum magnitudes of Spearman's rho in the matrix were about -0.72 between stream width at D90 and three metrics-RMSE, $Q_{\text {same }}-Q_{\text {prev }}>Q_{\text {same }}$, and $Q_{\text {same }}-Q_{\text {prev }}>Q_{\text {prev }}$. For all three, stability increased as width increased. As this was still a weak correlation, it was not pursued further during this study.

\section{Caveats, Limitations, and Suggestions for Further Study}

Several important sources of error in provisional flow data that are corrected in final flow data are missed by the process used to develop AltFlows. Most important and common are errors that are not caused by changes to the control and therefore are not corrected by changing ratings or shifts. These include ice-affected flows or missing records, which generally are estimated by hydrographic comparison to other streamgages. These errors might be corrected or at least adjusted, or daily flows might be estimated for the period that was in error.

Reliability of the stage record is equal in importance with rating stability in their effects on the reliability of a site's flow data in real time. The likelihood of plugged intakes or buried or exposed orifices is a function of the frequency of sediment deposition at a given point in a stream and, as such, is a characteristic of a given site. A streamgage may have a stable control but still be prone to recurring problems with the stage record that result in unreliable provisional data. The method developed to estimate $Q_{\text {prev }}$ in this study does not account for problematic stage records.

Another difference between provisional and approved data not accounted for by the AltFlow procedure is that expanded shifted ratings were selected as snapshots at the times when flow was measured and the tens of thousands of other rating changes were ignored. Days when measurements were made have no particular relevance to the beginning or ending of shifts and rating changes. As discussed previously, about one-third $(7,346$ of 23,126$)$ of shift entries began on days when flow was measured, and of these, 2,679 were apparently procedural entries for shifts that were implemented in multiple steps throughout the day. Forty-one percent of unique shifts $(6,842$ of 16,853$)$ began on days of peaks, either floods or high-flow pulses, and another 7 percent $(1,144$ of $16,853)$ began the day after a peak. Many of the shifts that began on days when measurements were made began on days of peaks and high-flow pulses. Prorating certain types of shifts through time is routine; the AltFlow procedure does not account for these changed shifts. As a result, the AltFlow time series is unlikely to have much relation to provisional data as they initially appeared on the web, with the possible exception 


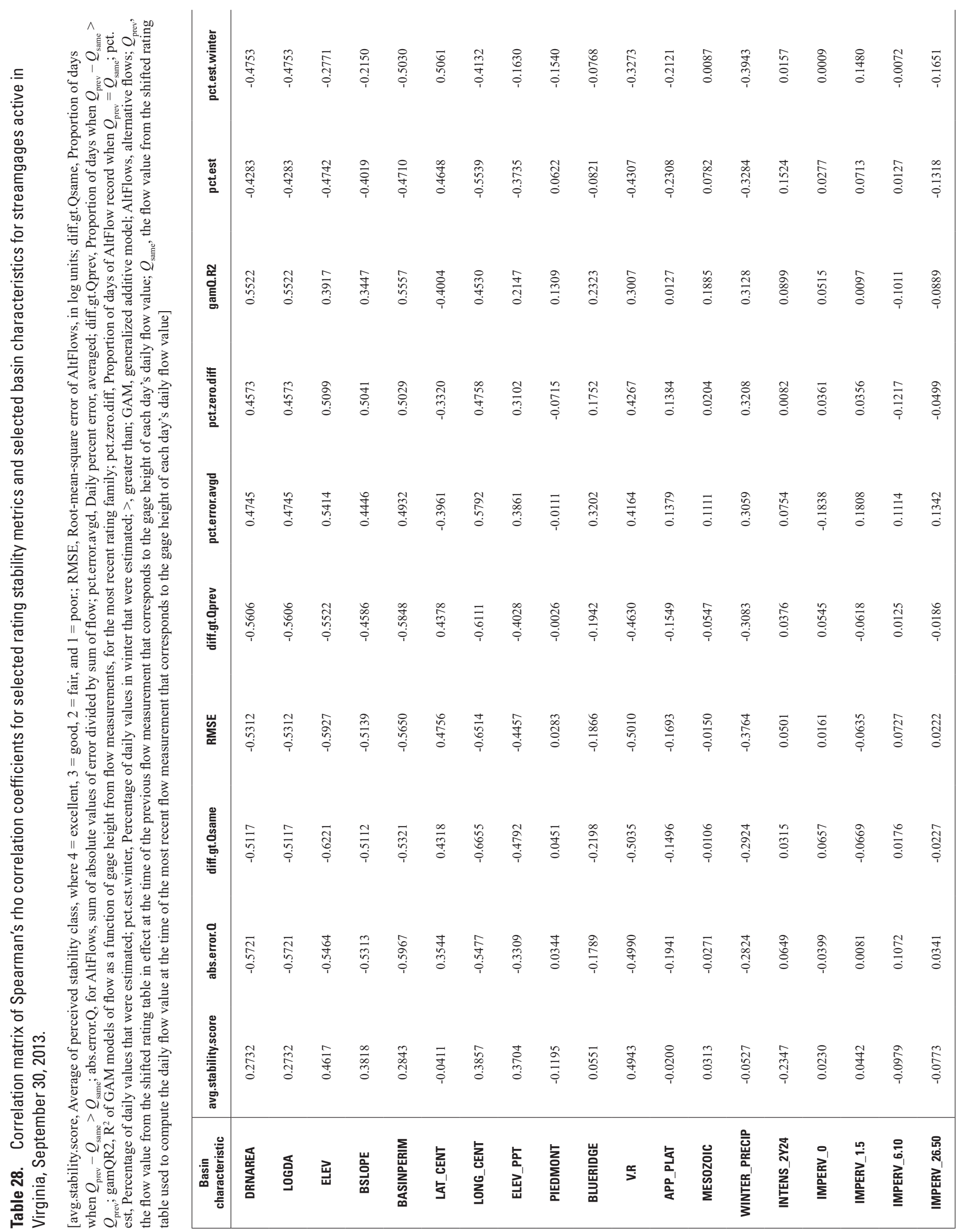


of the end of the study period. AltFlows do, however, provide information on changes in the shifted rating from site visit to site visit, and it provides information on how that shifted rating changed throughout the range of observed flows.

All of the stability metrics that were developed and proposed through the course of this study are difficult to verify externally because there is no previous, widely accepted external definition of rating stability. To the extent that descriptive stability classes are valid, they serve as an external check on the other metrics. Since the metrics all compared imprecisely to the descriptive stability classes, which themselves were imprecise, they all are imprecise measurements of rating stability or flow record reliability. Other than that comparison, the metrics were selected in terms of correlation to each other, and those correlations were generally fairly weak. These stability metrics are probably appropriate to use to separate streamgages into general classes of Excellent, Good, Fair, and Poor, but small differences in a metric are unlikely to mean very much.

Descriptions from hydrographer interviews were essential for interpreting quantitative analyses. The survey in which hydrographers were asked to grade control stability on a numeric scale was weakened by differences in individual impressions about stability. The stability scores provided by the individual hydrographer who was familiar with the most streamgages were correlated more strongly with quantitative metrics than were the averaged scores. Inconsistent impressions about stability are unlikely to make a substantial difference in flow data computation but greatly complicate creating and interpreting a survey of hydrographers about controls conditions. The survey process might have been stronger had it been done as a round-table discussion among senior hydrographers and differences in perspective about sites that were rated differently by different people had been resolved.

Future studies might consider attempting to separate individual ratings into parts representing section control, channel control, and overbank flow, and treating them separately. During the course of this study, exploratory analysis was done using dominant particle-size information captured during flow measurements. The analysis was less conclusive than seemed plausible. Quantitative measures of section control particle size might allow more conclusive analysis.

\section{Summary}

The U.S. Geological Survey, in cooperation with the Virginia Department of Environmental Quality, has quantified several measures of rating stability and the frequency and magnitude of changes to ratings through time for 174 real-time continuous streamgages active in Virginia as of September 30, 2013. The purpose of this report is to quantify the stability of stage-flow ratings in Virginia to help evaluate their reliability in providing real-time flow data. Relations between stage and flow from all flow measurements available at each site were determined. Mean daily flows for water years 1991-2013 were compared to flows that would have been computed from the rating in effect when the previous flow measurement was made.

Flow data computation procedures have changed substantially during water years 1991-2013. Timing of record computation is among the most critical of these changes. From 1991 through 2001, the median number of days between the start date of the shift, the first date of data for which it was intended to modify, and the date it was created in the office by a hydrographer, fluctuated between about 240 and about 300 days. The 75 th percentile of days between start date and creation date of shifts was more than 365 for every year during that period. Beginning in 2002, in recognition of the growing importance to data users of near-real-time flow on the internet, a greater effort began to work records continuously. The median period between the start date of a shift and its final modification decreased by about 4 months from 2001 to 2002. Only in 2012 and 2013 did one-half of the shifts have a delay between start date and final modification of about 60 days, which is close to the 8 -week interval between routine streamgage visits.

Curves were fit through all available flow measurements for all the gages in Virginia's real-time network as of September 30, 2013, that had at least 20 flow measurements with positive flow values. Generalized additive models (GAMs) were found to fit measurements better than LOESS curves. The GAM curves served as an average long-term rating. For each measurement with a positive flow value, residuals from the GAM curve were calculated. The residuals were plotted as a time series and by Julian date. The time-series plots were used to identify major changes to the control, and the measurements in the periods of equilibrium between major changes were assigned to rating families. At the 174 sites, 301 rating families were identified. At 107 of the sites, all measurements fit a single rating family. An additional 127 rating families were identified at the 67 sites where there were 2 or more rating families. Documented explanations were found for 67 of those 127 rating families. The most common reasons for the control to change enough to represent a new rating family are moving the gage (28 times), floods (26 times), and construction activities including bridge construction and removal, weir and control construction and removal, and channel or bed modifications (13 times). Provisional flow data from any streamgage that has recently experienced a major flood, regardless of historical stability, is more uncertain than usual until post-flood evidence emerges that the rating has remained stable or, if changed, is again well defined.

A direct comparison between provisional flow data originally displayed on the web in near-real time and flow data approved for publication following subsequent flow measurements and review could not be made because provisional flow data have not been archived. As a substitute, alternative flow (AltFlow) tables were constructed for periods with complete records of shifts and ratings. Daily flows were acquired for these periods. Expanded shifted ratings were acquired for days during these periods when flow measurements were made. 
Gage heights corresponding to mean daily flows were backcalculated and identified as belonging to measurement-tomeasurement periods. These gage heights were then related to two sets of ratings, those in effect when the measurement-tomeasurement period began $\left(Q_{\text {same }}\right)$ and those in effect when the previous measurement-to-measurement period began $\left(Q_{\text {prev }}\right)$. $Q_{\text {same }}$ was used instead of the actual published daily values to avoid rounding errors. Data availability varied by site, even for sites with complete flow record throughout water years 1991-2013 because of differences among field offices in data archiving. Many sites with complete records of daily values for water years 1991-2013 had AltFlow records that began in 2002.

Several metrics that summarized AltFlow tables were computed and evaluated with particular importance being given to how well they agreed with descriptive stability classes developed from hydrographer interviews. Of these stability metrics, four were determined to be meaningful and to represent different aspects of control stability that might be relevant to water managers. Total root mean square error (RMSE) between log-transformed $Q_{\text {prev }}$ and $Q_{\text {same }}$ is affected by the magnitude and frequency of rating changes and the transformation weight changes throughout the range of flows so that high, medium, or low flows do not dominate the statistic. The number of days when the difference between $Q_{\text {prev }}$ and $Q_{\text {same }}$ is freater than $Q_{\text {same }}$ is a measure of relatively large rating changes, most of which come at low flow. The sum of absolute AltFlow error divided by total flow is a flow-weighted statistic that is strongly affected by large-magnitude rating changes, which are predominantly at the high end of the rating, and it is useful in evaluating rating stability relative to total volume of water in a period. Percentage of days with zero difference between $Q_{\text {prev }}$ and $Q_{\text {same }}$ is a measure of the frequency of rating change.

Three other meaningful metrics of control stability or provisional flow-data quality were computed. The coefficient of determination $\left(\mathrm{R}^{2}\right)$ of $\mathrm{GAM}_{\mathrm{Q}}$ is computed from flow measurements, not rating changes. Because most of the scatter on the GAM models is at the low end of the plot, $\mathrm{R}^{2}$ of $\mathrm{GAM}_{\mathrm{Q}}$ is most sensitive to variability at the low end of ratings. Unlike the various AltFlow metrics, it is independent of time, and unlike most of them, its magnitude is independent of the flow magnitude of the individual error. Percentage of total estimated days and percentage of estimated days in the winter are weakly related to control stability, if they are related to it at all, but provide information on the overall quality of the flow record and on the likelihood that historical winter record was affected by ice.

Correlations among metrics varied, indicating they responded to different aspects of control stability. Correlations among most of the error terms derived from AltFlows were generally the strongest of the entire set. As an example, the magnitude of Spearman's rho between AltFlow RMSE and 5 of the other 6 such terms ranged from 0.75 to 0.90 . The $\mathrm{R}^{2}$ of $\mathrm{GAM}_{\mathrm{Q}}$ was correlated with the four meaningful AltFlow stability metrics (Spearman's rho absolute values ranging from 0.5760 to 0.6960$)$.

The two candidate metrics that are based on percentages of estimates were strongly correlated to each other $($ rho $=0.8584)$. Both these metrics were weakly correlated with stability class, -0.2982 for total estimates and -0.1676 for winter estimates. Total estimates were moderately correlated with $\mathrm{R}^{2}$ of $\mathrm{GAM}_{\mathrm{Q}}$ and several of the AltFlow-derived metrics; the absolute value of rho was as high as 0.5200 with RMSE and greater than 0.4 for six of the other metrics.

Stepwise multiple regression analysis was done to determine whether relations among the various stability metrics and quantitative basin and site characteristics could be determined. These relations were weak, and the regression models were not meaningful. Review of scatterplot and correlation matrices also indicated few strong correlations between stability terms and basin characteristics. Although quantitative relations between stability metrics and basin and site characteristics were all weak, some common patterns emerged. Streamgages on large streams ( $>500$-square mile drainage area) and at high elevations $(>1,000$ feet) were more likely to have stable controls and ratings than streamgages on small streams $(<100$-square mile drainage area) and at low elevations $(<500$ feet). Streamgages in western Virginia were more likely to have stable controls than were streamgages in northeastern Virginia, particularly small streams. There were exceptions to all three generalizations, and streamgages that were intermediate in those characteristics varied widely in stability.

\section{References Cited}

Anning, D.W., 2001, Standard errors of annual discharge and change in reservoir content data from selected stations in the lower Colorado River streamflow-gaging station network, 1995-99: U.S. Geological Survey Water-Resources Investigations Report 01-4240, 81 p. [Also available at http://pubs.usgs.gov/wri/2001/4240/report.pdf.]

Austin, S.H., Krstolic, J.L., and Wiegand, Ute, 2011, Lowflow characteristics of Virginia streams: U.S. Geological Survey Scientific Investigations Report 2011-5143, 122 p., + 9 tables on CD. [Also available at https://pubs.er.usgs. gov/publication/sir20115143.]

Corbett, D.M., and others, 1943, Stream-gaging procedure-a manual describing methods and practices of the Geological Survey: U.S. Geological Survey Water-Supply Paper 888, 245 p. [Also available at https://pubs.er.usgs.gov/publication/wsp888.]

Fenneman, N.M., and Johnson, D.W., 1946, Physical divisions of the United States: U.S. Geological Survey Physiography Committee Special Map, scale 1:7,000,000. 
Hayes, D.C., 1989, Low-flow characteristics of streams in Virginia: U.S. Geological Survey Water-Supply Paper 2374, 69 p. [Also available at https://pubs.usgs.gov/wsp/wsp2374/.]

Helsel, D.R. and Hirsch, R.M. 2002, Statistical methods in water resources, USGS Techniques of Water Resources Investigations, book 4, chap. A3, 510 p.,accessed June 12, 2018, http:/water.usgs.gov/pubs/twri/twri4a3/.

Messinger, Terence, and Burgholzer, R.W., 2017, Ratings and estimated provisional streamflow for streamgages in Virginia, water years 1991 through 2013: U.S. Geological Survey data release, https://doi.org/10.5066/F72R3PXB.

Moss, M.E., and Gilroy, E.J., 1980, Cost-effective streamgaging strategies for the Lower Colorado River Basin: U.S. Geological Survey Open-File Report 80-1048, 111 p. [Also available at https://pubs.usgs.gov/of/1980/1048/report.pdf.]

Murphy, E.C., Hoyt, J.C., and Hollister, G.B., 1904, Hydrographic manual of the United States Geological Survey: U.S. Geological Survey Water Supply and Irrigation Paper 94, 76 p. [Also available at https://pubs.usgs.gov/wsp/0094/ report.pdf.]

Nelms, D.L., Harlow, G.E., Jr., Plummer, L.N., and Busenberg, Eurybiades, 2003, Aquifer susceptibility in Virginia, 1998-2000: U.S. Geological Survey Water-Resources Investigations Report 03-4278, 58 p., https://pubs.er.usgs. gov/publication/wri034278.

Nelms, D.L., Harlow, G.E., Jr., and Hayes, D.C., 1997, Baseflow characteristics of streams in the Valley and Ridge, the Blue Ridge, and the Piedmont Physiographic Provinces of Virginia: U.S. Geological Survey Water-Supply Paper 2457, 48 p., 1 pl. [Also available at https://pubs.usgs.gov/wsp/ wsp_2457/.]

R Core Team, 2014, R - a language and environment for statistical computing: Vienna, Austria, R Foundation for Statistical Computing, accessed September 2, 2016, at http://www.R-project.org/.

Rantz, S.E., and others, 1982, Measurement and computation of streamflow-Volume 1. Measurement of stage and discharge-Volume 2. Computation of discharge: U.S. Geological Survey Water-Supply Paper 2175, 631 p. [Also available at https://pubs.usgs.gov/wsp/wsp2175/.]

Sauer, V.B., and Turnipseed, D.P., 2010, Stage measurement at gaging stations: U.S. Geological Survey Techniques and Methods book 3, chap. A7, 45 p. [Also available at http:// pubs.usgs.gov/tm/tm3-a7/.]

Turnipseed, D.P., and Sauer, V.B., 2010, Discharge measurements at gaging stations: U.S. Geological Survey Techniques and Methods book 3, chap. A8, 87 p. [Also available at http://pubs.usgs.gov/tm/tm3-a8/.]
U.S. Census Bureau, 2015, Cartographic boundary shapefiles_-states, accessed November 15, 2017, at https://www. census.gov/geo/maps-data/data/cbf/cbf_state.html.

U.S. Geological Survey, 1998, A new evaluation of the USGS streamgaging network-A report to Congress, 20 p., accessed November 15, 2017, at http:/water.usgs.gov/ streamgaging/report.pdf.

U.S. Geological Survey, 2005, Streams and waterbodies, two-million scale, accessed November 15, 2017, at http:// nationalmap.gov/.

U.S. Geological Survey, 2007, National Elevation Dataset 1 arc-second, accessed September 22, 2017, at http://viewer. nationalmap.gov/viewer/.

U.S. Geological Survey, 2016a, Annual Water Data Reports, accessed May 5, 2017, at https://wdr.water.usgs.gov/.

U.S. Geological Survey, 2016b, National Water Information System: Web Interface, Current water data for the Nation, accessed September 22, 2017, at http://waterdata.usgs.gov/ usa/nwis/rt.

U.S. Geological Survey, 2017, Water-Year Summary for Site USGS 02037000, accessed May 5, 2017, at https:/waterdata.usgs.gov/va/nwis/wys_rpt/?site_ no=02037000\&agency_cd=USGS.

Wahl, K.L., Thomas, W.O., Jr., and Hirsch, R.M., 1995, The stream-gaging program of the U.S. Geological Survey: U.S. Geological Survey Circular 1123, 22 p., accessed December 22, 2016, at http://pubs.usgs.gov/circ/circ1123/overview. html.

Wickham, H., 2011, The Split-Apply-Combine Strategy for data analysis: Journal of Statistical Software, v. 40, no. 1, p. 1-29, accessed September 2, 2016 at http://www.jstatsoft. org/v40/i01/.

Wickham, H., 2009, ggplot2-Elegant graphics for data analysis: Springer-Verlag, New York, 212 p.

Wood, S.N., 2011, Fast stable restricted maximum likelihood and marginal likelihood estimation of semiparametric generalized linear models: Journal of the Royal Statistical Society (B), v. 73, no. 1, p. 3-36.

Wood, S.N., 2014, mgcv-Mixed GAM Computation Vehicle with GCV/AIC/REML smoothness estimation, accessed January 7, 2014, at http://cran.r-project.org/web/packages/ mgcv/index.html. 
Table 2. Earliest dates for base ratings and shifts in the Virginia node of the National Water Information System database for streamgages active as of September 30, 2013.

[VA, Virginia; Rt, Route]

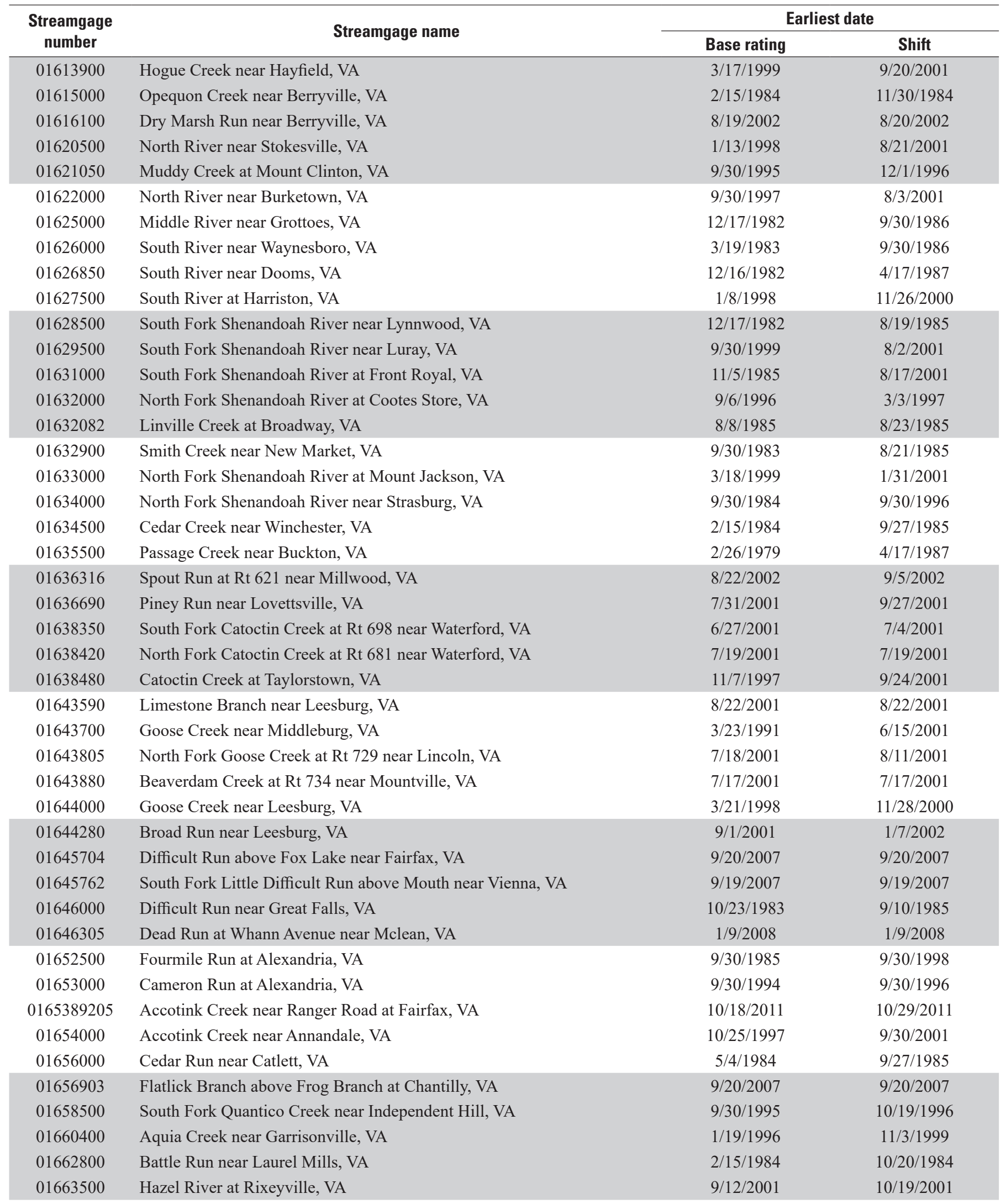


Table 2. Earliest dates for base ratings and shifts in the Virginia node of the National Water Information System database for streamgages active as of September 30, 2013. - Continued

[VA, Virginia; Rt, Route]

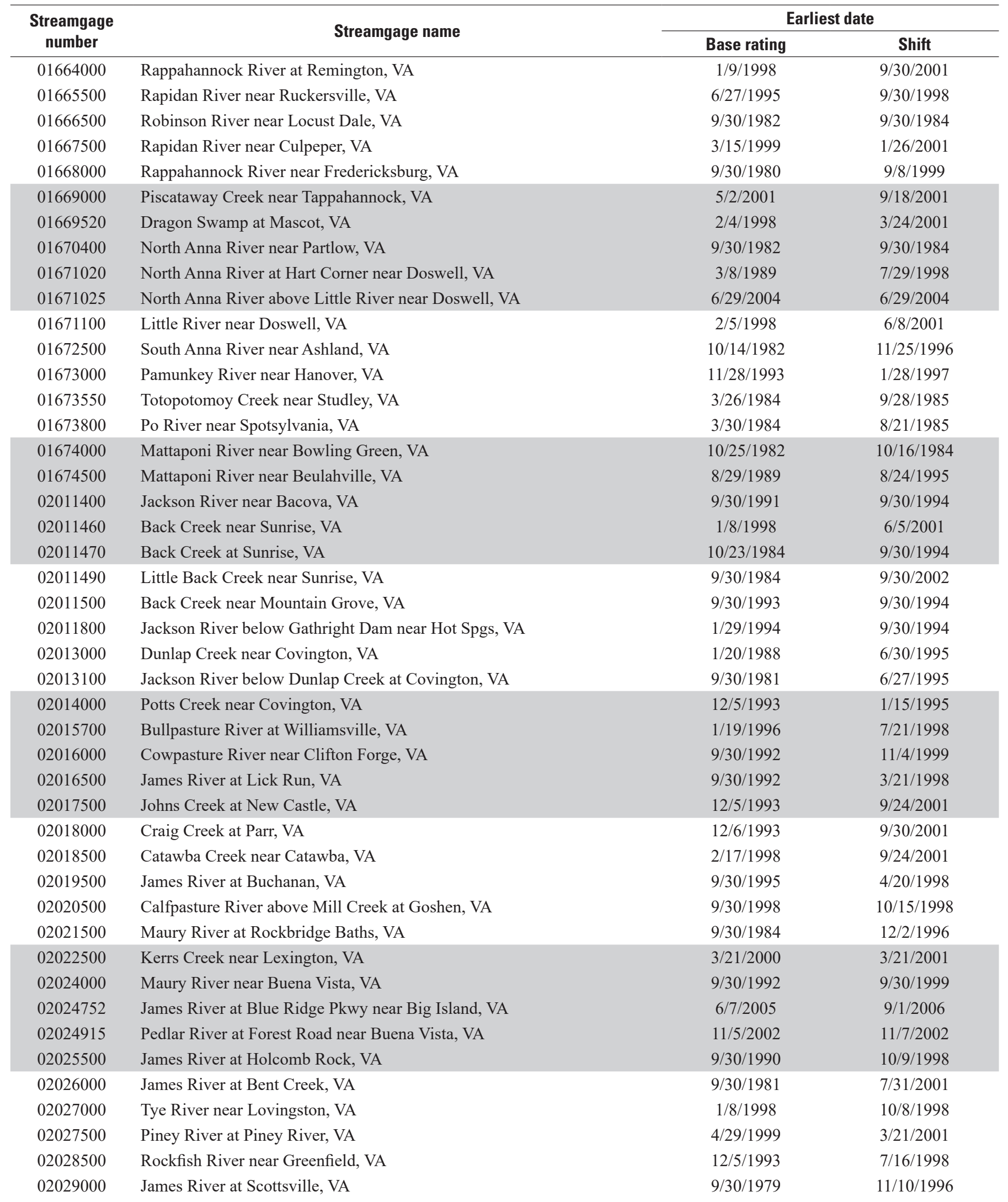


Table 2. Earliest dates for base ratings and shifts in the Virginia node of the National Water Information System database for streamgages active as of September 30, 2013.-Continued

[VA, Virginia; Rt, Route]

\begin{tabular}{|c|c|c|c|}
\hline \multirow{2}{*}{$\begin{array}{c}\text { Streamgage } \\
\text { number }\end{array}$} & \multirow{2}{*}{ Streamgage name } & \multicolumn{2}{|c|}{ Earliest date } \\
\hline & & Base rating & Shift \\
\hline 02030000 & Hardware River below Briery Run near Scottsville, VA & 9/30/1989 & 9/10/1997 \\
\hline 02031000 & Mechums River near White Hall, VA & $2 / 23 / 1994$ & $9 / 17 / 2001$ \\
\hline 02032250 & Moormans River near Free Union, VA & $11 / 3 / 1985$ & $7 / 6 / 2005$ \\
\hline 02032640 & North Fork Rivanna River near Earlysville, VA & 9/30/1993 & 9/30/1993 \\
\hline 02035000 & James River at Cartersville, VA & $11 / 6 / 1985$ & $7 / 29 / 1986$ \\
\hline 02036500 & Fine Creek at Fine Creek Mills, VA & $11 / 26 / 1983$ & $10 / 2 / 1984$ \\
\hline 02037000 & James River And Kanawha Canal near Richmond, VA & $9 / 30 / 1993$ & $3 / 29 / 2001$ \\
\hline 02037500 & James River near Richmond, VA & $10 / 9 / 1996$ & 9/30/1997 \\
\hline 02038850 & Holiday Creek near Andersonville, VA & $9 / 30 / 1999$ & $6 / 5 / 2001$ \\
\hline 02040892 & Appomattox River at Route 602 near Mannboro, VA & $6 / 21 / 2011$ & $6 / 21 / 2011$ \\
\hline 02041000 & Deep Creek near Mannboro, VA & $11 / 27 / 1983$ & $10 / 2 / 1984$ \\
\hline 02041650 & Appomattox River at Matoaca, VA & $12 / 3 / 1993$ & $6 / 17 / 2000$ \\
\hline 02042500 & Chickahominy River near Providence Forge, VA & 9/30/1993 & 12/9/1996 \\
\hline 02044500 & Nottoway River near Rawlings, VA & $4 / 18 / 2000$ & $6 / 5 / 2001$ \\
\hline 02045500 & Nottoway River near Stony Creek, VA & $9 / 30 / 1984$ & $10 / 2 / 1984$ \\
\hline 02046000 & Stony Creek near Dinwiddie, VA & $3 / 22 / 2001$ & $9 / 26 / 2001$ \\
\hline 02047000 & Nottoway River near Sebrell, VA & 2/9/1998 & $9 / 30 / 2000$ \\
\hline 02047500 & Blackwater River near Dendron, VA & $2 / 21 / 1982$ & $10 / 1 / 1984$ \\
\hline 02055000 & Roanoke River at Roanoke, VA & $3 / 29 / 1994$ & $8 / 20 / 2000$ \\
\hline 02055100 & Tinker Creek near Daleville, VA & $9 / 30 / 1993$ & 9/30/1996 \\
\hline 02056000 & Roanoke River at Niagara, VA & 9/30/1992 & $1 / 24 / 2001$ \\
\hline 02056650 & Back Creek near Dundee, VA & 9/30/1999 & $9 / 30 / 2001$ \\
\hline 02056900 & Blackwater River near Rocky Mount, VA & $1 / 15 / 1995$ & $3 / 30 / 2001$ \\
\hline 02058400 & Pigg River near Sandy Level, VA & 9/7/1987 & $9 / 8 / 1997$ \\
\hline 02059485 & Goose Creek at Rt 747 near Bunker Hill, VA & $9 / 29 / 2006$ & $9 / 15 / 2007$ \\
\hline 02059500 & Goose Creek near Huddleston, VA & $9 / 30 / 1995$ & $10 / 14 / 2001$ \\
\hline 02060500 & Roanoke River at Altavista, VA & $11 / 5 / 1985$ & $9 / 26 / 1988$ \\
\hline 02061000 & Big Otter River near Bedford, VA & $12 / 10 / 2006$ & $8 / 5 / 2007$ \\
\hline 02061500 & Big Otter River near Evington, VA & $12 / 5 / 1993$ & $6 / 6 / 2001$ \\
\hline 02062500 & Roanoke (Staunton) River at Brookneal, VA & 9/30/1992 & $10 / 3 / 1995$ \\
\hline 02064000 & Falling River near Naruna, VA & $2 / 15 / 1984$ & $5 / 25 / 1985$ \\
\hline 02065500 & Cub Creek at Phenix, VA & $11 / 28 / 1993$ & $10 / 8 / 1998$ \\
\hline 02066000 & Roanoke (Staunton) River at Randolph, VA & $8 / 18 / 1985$ & $6 / 24 / 1995$ \\
\hline
\end{tabular}


Table 2. Earliest dates for base ratings and shifts in the Virginia node of the National Water Information System database for streamgages active as of September 30, 2013. - Continued

[VA, Virginia; Rt, Route]

\begin{tabular}{|c|c|c|c|}
\hline \multirow{2}{*}{$\begin{array}{c}\text { Streamgage } \\
\text { number }\end{array}$} & \multirow{2}{*}{ Streamgage name } & \multicolumn{2}{|c|}{ Earliest date } \\
\hline & & Base rating & Shift \\
\hline 02069700 & South Mayo River near Nettleridge, VA & $3 / 20 / 2000$ & $3 / 20 / 2001$ \\
\hline 02071530 & Smith River at Smith Riv Church near Woolwine, VA & $10 / 20 / 1994$ & $7 / 29 / 1997$ \\
\hline 02072000 & Smith River near Philpott, VA & $6 / 10 / 1981$ & $10 / 7 / 1997$ \\
\hline 02072500 & Smith River at Bassett, VA & $9 / 30 / 1985$ & $9 / 30 / 1995$ \\
\hline 02074500 & Sandy River near Danville, VA & $1 / 5 / 1982$ & $6 / 29 / 1985$ \\
\hline 02075045 & Dan River at Stp near Danville, VA & 9/30/1993 & 10/7/1996 \\
\hline 02075500 & Dan River at Paces, VA & $11 / 2 / 1981$ & $10 / 3 / 1995$ \\
\hline 02077000 & Banister River at Halifax, VA & $10 / 18 / 1981$ & $1 / 4 / 1985$ \\
\hline 02077500 & Hyco River near Denniston, VA & 9/30/1984 & $10 / 5 / 1996$ \\
\hline 03165500 & New River at Ivanhoe, VA & $12 / 2 / 1996$ & 9/30/1997 \\
\hline 03167000 & Reed Creek at Grahams Forge, VA & $6 / 5 / 1992$ & $1 / 20 / 2001$ \\
\hline 03168000 & New River at Allisonia, VA & $11 / 24 / 1992$ & $9 / 30 / 1994$ \\
\hline 03170000 & Little River at Graysontown, VA & $9 / 30 / 1991$ & $9 / 30 / 2000$ \\
\hline 03171000 & New River at Radford, VA & 9/30/1989 & 9/30/1994 \\
\hline 03173000 & Walker Creek at Bane, VA & $3 / 25 / 1993$ & 9/30/1994 \\
\hline 03175500 & Wolf Creek near Narrows, VA & $11 / 5 / 1985$ & 9/30/1994 \\
\hline 03176500 & New River at Glen Lyn, VA & $3 / 25 / 1993$ & 9/30/1994 \\
\hline 03177710 & Bluestone River at Falls Mills, VA & $3 / 24 / 1993$ & $8 / 25 / 1993$ \\
\hline 03474000 & Middle Fork Holston River at Seven Mile Ford, VA & $10 / 9 / 1976$ & 9/30/1996 \\
\hline 03475000 & Middle Fork Holston River near Meadowview, VA & $1 / 4 / 1992$ & 9/30/1996 \\
\hline 03478400 & Beaver Creek at Bristol, VA & 9/30/1991 & 9/30/1996 \\
\hline 03488000 & North Fork Holston River near Saltville, VA & $1 / 13 / 1989$ & $9 / 30 / 1996$ \\
\hline 03490000 & North Fork Holston River near Gate City, VA & $3 / 31 / 2012$ & $12 / 27 / 2012$ \\
\hline 03524000 & Clinch River at Cleveland, VA & $12 / 24 / 1992$ & $10 / 2 / 1995$ \\
\hline 03524500 & Guest River at Coeburn, VA & $8 / 1 / 2012$ & $4 / 20 / 2013$ \\
\hline 03527000 & Clinch River at Speers Ferry, VA & $9 / 30 / 2001$ & $10 / 3 / 2001$ \\
\hline 03529500 & Powell River at Big Stone Gap, VA & $9 / 30 / 2001$ & $10 / 3 / 2001$ \\
\hline 03531500 & Powell River near Jonesville, VA & 9/30/1994 & 9/30/1995 \\
\hline
\end{tabular}




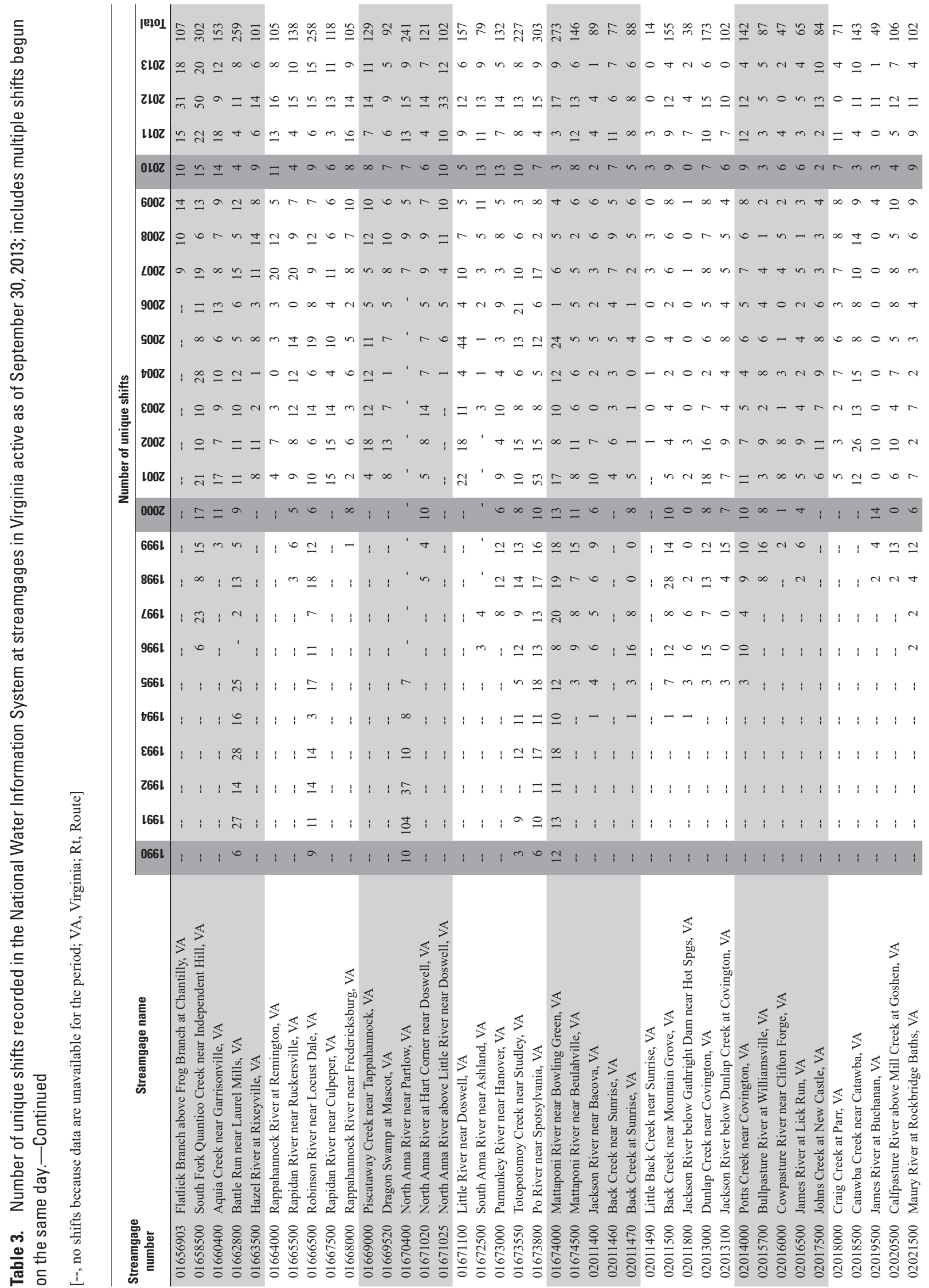




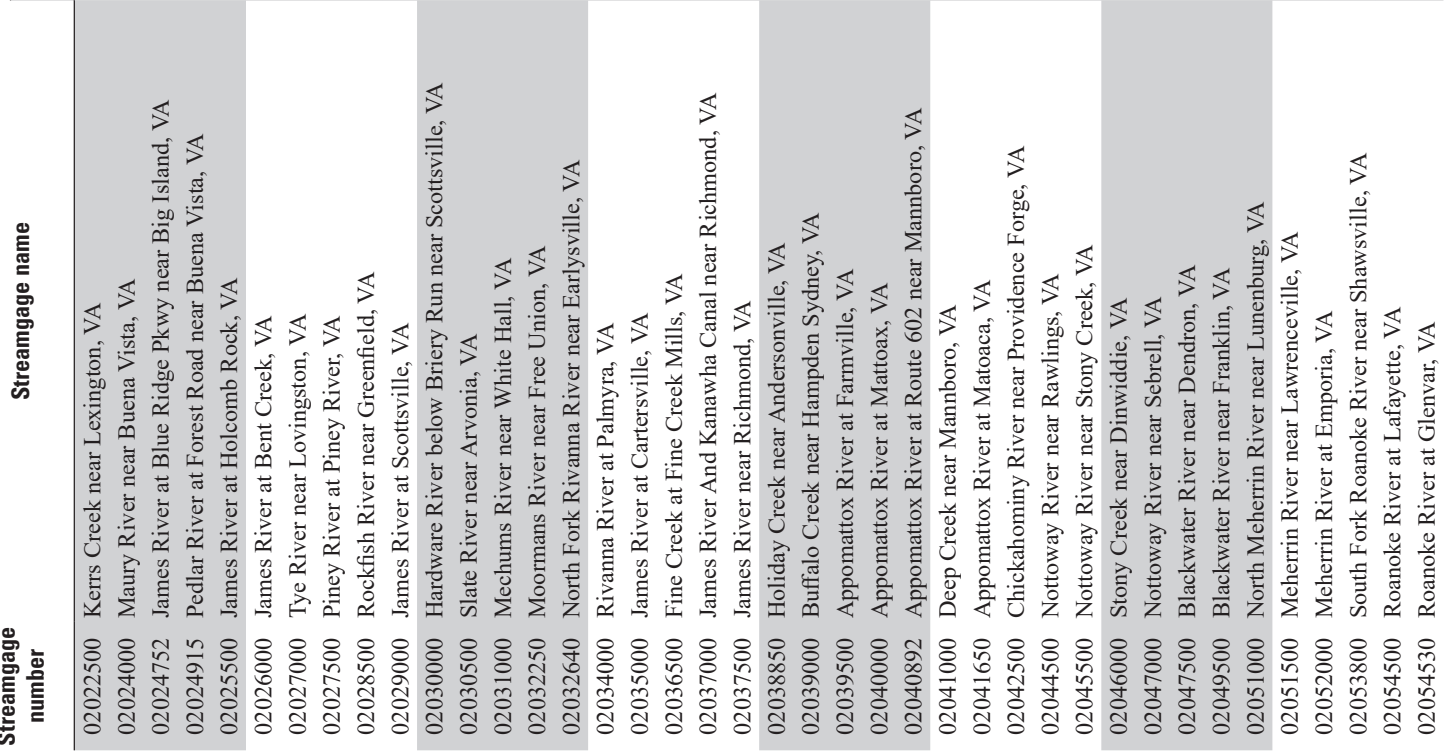




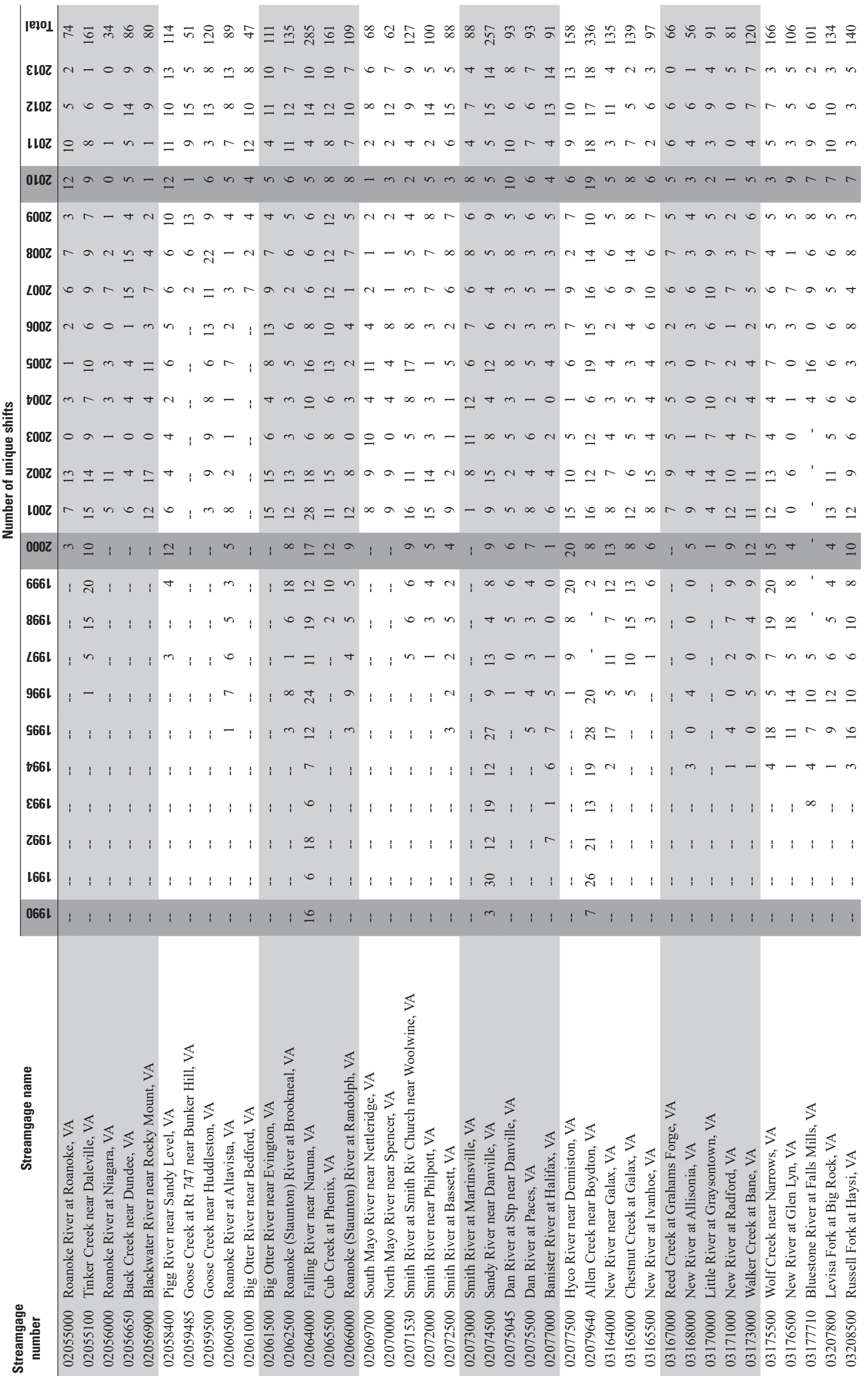




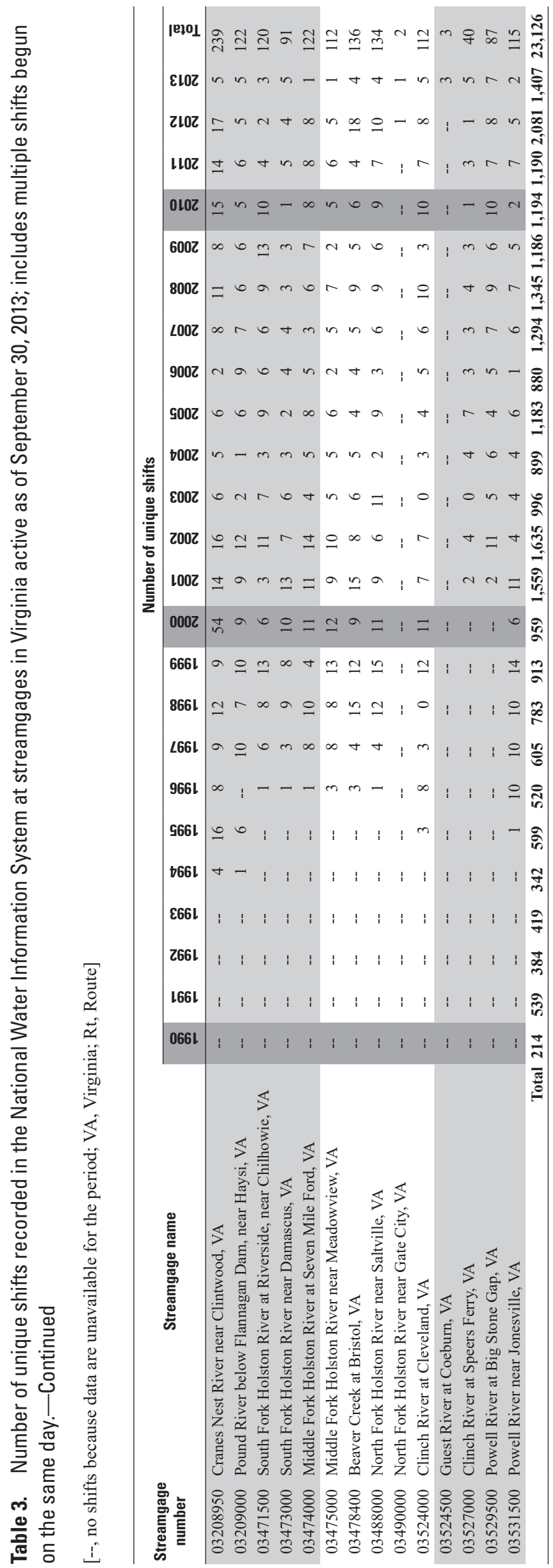


Table 4. Number of base ratings and number of days they were in effect for streamgages in Virginia, water years 1991-2013, for periods when the ratings were stored in the National Water Information System.

[VA, Virginia; Rt, Route]

\begin{tabular}{|c|c|c|c|c|}
\hline $\begin{array}{l}\text { Streamgage } \\
\text { number }\end{array}$ & Streamgage name & $\begin{array}{l}\text { Number of base } \\
\text { ratings available }\end{array}$ & $\begin{array}{l}\text { Number of days } \\
\text { those ratings } \\
\text { were in effect }\end{array}$ & $\begin{array}{l}\text { Average days } \\
\text { per rating }\end{array}$ \\
\hline 01613900 & Hogue Creek near Hayfield, VA & 2 & 5,312 & 2,656 \\
\hline 01615000 & Opequon Creek near Berryville, VA & 9 & 6,594 & 733 \\
\hline 01616100 & Dry Marsh Run near Berryville, VA & 1 & 4,061 & 4,061 \\
\hline 01620500 & North River near Stokesville, VA & 6 & 5,741 & 957 \\
\hline 01621050 & Muddy Creek at Mount Clinton, VA & 4 & 6,576 & 1,644 \\
\hline 01622000 & North River near Burketown, VA & 1 & 5,845 & 5,845 \\
\hline 01625000 & Middle River near Grottoes, VA & 3 & 8,402 & 2,801 \\
\hline 01626000 & South River near Waynesboro, VA & 2 & 8,402 & 4,201 \\
\hline 01626850 & South River near Dooms, VA & 6 & 5,257 & 876 \\
\hline 01627500 & South River at Harriston, VA & 2 & 5,745 & 2,873 \\
\hline 01628500 & South Fork Shenandoah River near Lynnwood, VA & 2 & 8,402 & 4,201 \\
\hline 01629500 & South Fork Shenandoah River near Luray, VA & 4 & 5,115 & 1,279 \\
\hline 01631000 & South Fork Shenandoah River at Front Royal, VA & 3 & 8,402 & 2,801 \\
\hline 01632000 & North Fork Shenandoah River at Cootes Store, VA & 7 & 6,234 & 891 \\
\hline 01632082 & Linville Creek at Broadway, VA & 4 & 8,402 & 2,101 \\
\hline 01632900 & Smith Creek near New Market, VA & 6 & 8,402 & 1,400 \\
\hline 01633000 & North Fork Shenandoah River at Mount Jackson, VA & 1 & 5,312 & 5,312 \\
\hline 01634000 & North Fork Shenandoah River near Strasburg, VA & 4 & 8,402 & 2,101 \\
\hline 01634500 & Cedar Creek near Winchester, VA & 3 & 8,402 & 2,801 \\
\hline 01635500 & Passage Creek near Buckton, VA & 2 & 8,402 & 4,201 \\
\hline 01636316 & Spout Run at Rt 621 near Millwood, VA & 2 & 4,059 & 2,029 \\
\hline 01636690 & Piney Run near Lovettsville, VA & 4 & 4,445 & 1,111 \\
\hline 01638350 & South Fork Catoctin Creek at Rt 698 near Waterford, VA & 4 & 4,480 & 1,120 \\
\hline 01638420 & North Fork Catoctin Creek at Rt 681 near Waterford, VA & 4 & 4,457 & 1,114 \\
\hline 01638480 & Catoctin Creek at Taylorstown, VA & 2 & 5,807 & 2,904 \\
\hline 01643590 & Limestone Branch near Leesburg, VA & 4 & 4,424 & 1,106 \\
\hline 01643700 & Goose Creek near Middleburg, VA & 8 & 6,616 & 827 \\
\hline 01643805 & North Fork Goose Creek at Rt 729 near Lincoln, VA & 6 & 4,458 & 743 \\
\hline 01643880 & Beaverdam Creek at Rt 734 near Mountville, VA & 9 & 4,460 & 496 \\
\hline 01644000 & Goose Creek near Leesburg, VA & 2 & 5,673 & 2,837 \\
\hline 01644280 & Broad Run near Leesburg, VA & 6 & 4,414 & 736 \\
\hline 01645704 & Difficult Run above Fox Lake near Fairfax, VA & 4 & 2,203 & 551 \\
\hline 01645762 & South Fork Little Difficult Run above Mouth near Vienna, VA & 5 & 2,204 & 441 \\
\hline 01646000 & Difficult Run near Great Falls, VA & 6 & 8,402 & 1,400 \\
\hline 01646305 & Dead Run at Whann Avenue near Mclean, VA & 3 & 2,092 & 697 \\
\hline 01652500 & Fourmile Run at Alexandria, VA & 4 & 8,402 & 2,101 \\
\hline 01653000 & Cameron Run at Alexandria, VA & 5 & 6,941 & 1,388 \\
\hline 0165389205 & Accotink Creek near Ranger Road at Fairfax, VA & 2 & 714 & 357 \\
\hline 01654000 & Accotink Creek near Annandale, VA & 4 & 5,821 & 1,455 \\
\hline 01656000 & Cedar Run near Catlett, VA & 5 & 8,402 & 1,680 \\
\hline 01656903 & Flatlick Branch above Frog Branch at Chantilly, VA & 5 & 2,204 & 441 \\
\hline 01658500 & South Fork Quantico Creek near Independent Hill, VA & 4 & 6,576 & 1,644 \\
\hline 01660400 & Aquia Creek near Garrisonville, VA & 4 & 5,716 & 1,429 \\
\hline 01662800 & Battle Run near Laurel Mills, VA & 7 & 7,588 & 1,084 \\
\hline 01663500 & Hazel River at Rixeyville, VA & 6 & 4,402 & 734 \\
\hline
\end{tabular}


Table 4. Number of base ratings and number of days they were in effect for streamgages in Virginia, water years 1991-2013, for periods when the ratings were stored in the National Water Information System.-Continued

[VA, Virginia; Rt, Route]

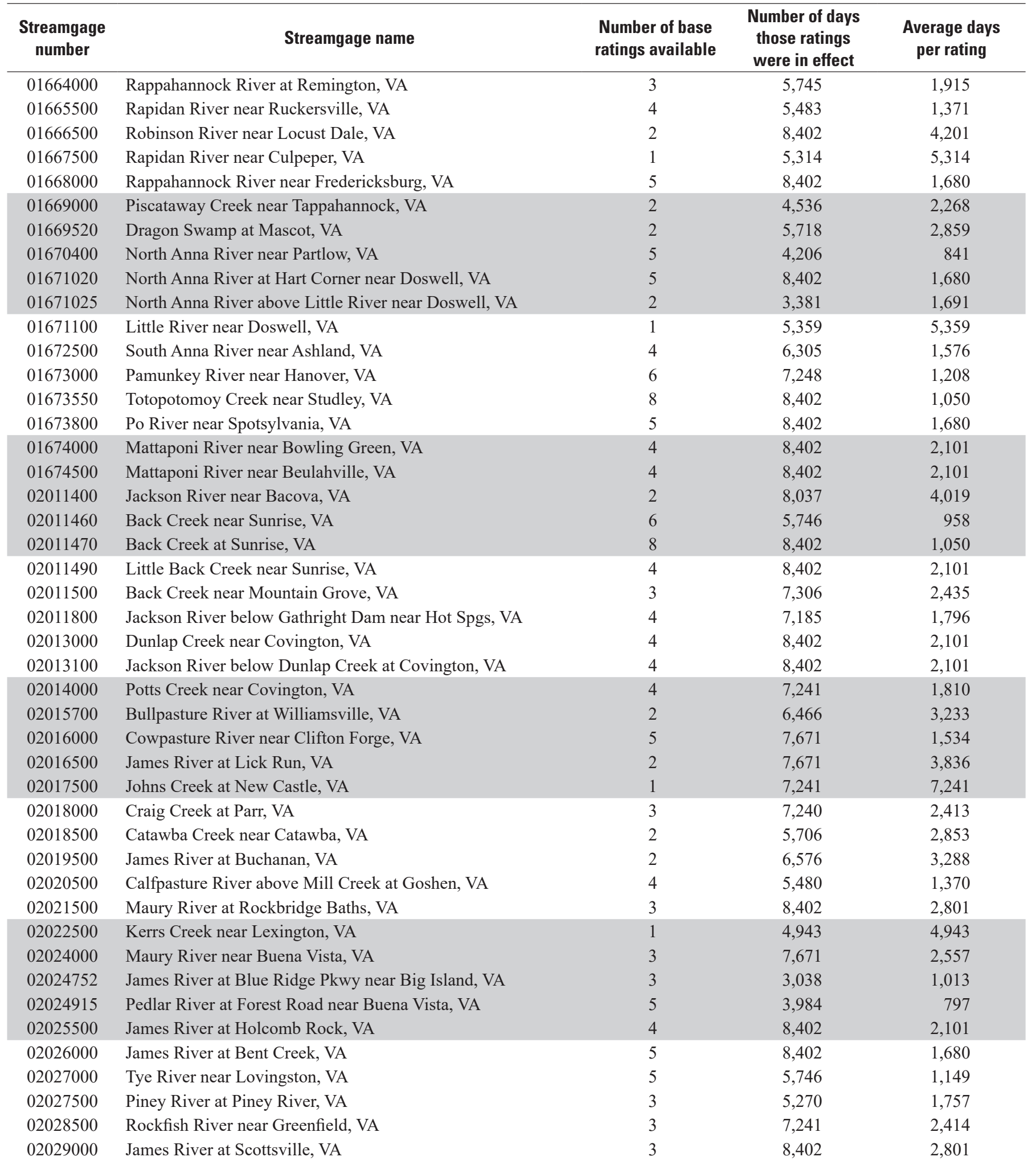


Table 4. Number of base ratings and number of days they were in effect for streamgages in Virginia, water years 1991-2013, for periods when the ratings were stored in the National Water Information System.-Continued

[VA, Virginia; Rt, Route]

\begin{tabular}{|c|c|c|c|c|}
\hline $\begin{array}{c}\text { Streamgage } \\
\text { number }\end{array}$ & Streamgage name & $\begin{array}{l}\text { Number of base } \\
\text { ratings available }\end{array}$ & $\begin{array}{c}\text { Number of days } \\
\text { those ratings } \\
\text { were in effect }\end{array}$ & $\begin{array}{c}\text { Average days } \\
\text { per rating }\end{array}$ \\
\hline 02030000 & Hardware River below Briery Run near Scottsville, VA & 3 & 8,045 & 2,682 \\
\hline 02031000 & Mechums River near White Hall, VA & 2 & 7,160 & 3,580 \\
\hline 02032250 & Moormans River near Free Union, VA & 5 & 5,565 & 1,113 \\
\hline 02035000 & James River at Cartersville, VA & 2 & 8,402 & 4,201 \\
\hline 02036500 & Fine Creek at Fine Creek Mills, VA & 5 & 8,402 & 1,680 \\
\hline 02037000 & James River And Kanawha Canal near Richmond, VA & 3 & 7,306 & 2,435 \\
\hline 02037500 & James River near Richmond, VA & 4 & 6,202 & 1,550 \\
\hline 02038850 & Holiday Creek near Andersonville, VA & 3 & 5,115 & 1,705 \\
\hline 02040892 & Appomattox River at Route 602 near Mannboro, VA & 2 & 833 & 417 \\
\hline 02041000 & Deep Creek near Mannboro, VA & 6 & 8,402 & 1,400 \\
\hline 02041650 & Appomattox River at Matoaca, VA & 3 & 7,243 & 2,414 \\
\hline 02042500 & Chickahominy River near Providence Forge, VA & 8 & 7,306 & 913 \\
\hline 02044500 & Nottoway River near Rawlings, VA & 1 & 4,915 & 4,915 \\
\hline 02045500 & Nottoway River near Stony Creek, VA & 7 & 7,569 & 1,081 \\
\hline 02046000 & Stony Creek near Dinwiddie, VA & 2 & 4,577 & 2,288 \\
\hline 02047000 & Nottoway River near Sebrell, VA & 6 & 5,714 & 952 \\
\hline 02047500 & Blackwater River near Dendron, VA & 6 & 8,402 & 1,400 \\
\hline 02049500 & Blackwater River near Franklin, VA & 9 & 8,402 & 934 \\
\hline 02051000 & North Meherrin River near Lunenburg, VA & 3 & 5,719 & 1,906 \\
\hline 02055100 & Tinker Creek near Daleville, VA & 2 & 7,306 & 3,653 \\
\hline 02056000 & Roanoke River at Niagara, VA & 2 & 7,671 & 3,836 \\
\hline 02056650 & Back Creek near Dundee, VA & 3 & 5,115 & 1,705 \\
\hline 02056900 & Blackwater River near Rocky Mount, VA & 2 & 6,835 & 3,417 \\
\hline 02058400 & Pigg River near Sandy Level, VA & 4 & 8,402 & 2,101 \\
\hline 02059485 & Goose Creek at Rt 747 near Bunker Hill, VA & 4 & 2,559 & 640 \\
\hline 02059500 & Goose Creek near Huddleston, VA & 2 & 6,576 & 3,288 \\
\hline 02060500 & Roanoke River at Altavista, VA & 3 & 8,402 & 2,801 \\
\hline 02061000 & Big Otter River near Bedford, VA & 3 & 2,488 & 829 \\
\hline 02061500 & Big Otter River near Evington, VA & 2 & 7,240 & 3,620 \\
\hline 02062500 & Roanoke (Staunton) River at Brookneal, VA & 4 & 7,671 & 1,918 \\
\hline 02064000 & Falling River near Naruna, VA & 5 & 8,402 & 1,680 \\
\hline 02065500 & Cub Creek at Phenix, VA & 1 & 7,247 & 7,247 \\
\hline 02066000 & Roanoke (Staunton) River at Randolph, VA & 2 & 8,402 & 4,201 \\
\hline
\end{tabular}


Table 4. Number of base ratings and number of days they were in effect for streamgages in Virginia, water years 1991-2013, for periods when the ratings were stored in the National Water Information System. - Continued

[VA, Virginia; Rt, Route]

\begin{tabular}{|c|c|c|c|c|}
\hline $\begin{array}{c}\text { Streamgage } \\
\text { number }\end{array}$ & Streamgage name & $\begin{array}{l}\text { Number of base } \\
\text { ratings available }\end{array}$ & $\begin{array}{l}\text { Number of days } \\
\text { those ratings } \\
\text { were in effect }\end{array}$ & $\begin{array}{c}\text { Average days } \\
\text { per rating }\end{array}$ \\
\hline 02069700 & South Mayo River near Nettleridge, VA & 1 & 4,943 & 4,943 \\
\hline 02071530 & Smith River at Smith Riv Church near Woolwine, VA & 6 & 6,922 & 1,154 \\
\hline 02072000 & Smith River near Philpott, VA & 4 & 8,402 & 2,101 \\
\hline 02074500 & Sandy River near Danville, VA & 2 & 8,402 & 4,201 \\
\hline 02075045 & Dan River at Stp near Danville, VA & 5 & 7,306 & 1,461 \\
\hline 02075500 & Dan River at Paces, VA & 1 & 2,876 & 2,876 \\
\hline 02077000 & Banister River at Halifax, VA & 5 & 8,290 & 1,658 \\
\hline 02077500 & Hyco River near Denniston, VA & 5 & 5,840 & 1,168 \\
\hline 03165500 & New River at Ivanhoe, VA & 5 & 6,148 & 1,230 \\
\hline 03167000 & Reed Creek at Grahams Forge, VA & 2 & 7,789 & 3,894 \\
\hline 03168000 & New River at Allisonia, VA & 2 & 7,617 & 3,808 \\
\hline 03170000 & Little River at Graysontown, VA & 4 & 8,037 & 2,009 \\
\hline 03171000 & New River at Radford, VA & 2 & 8,402 & 4,201 \\
\hline 03173000 & Walker Creek at Bane, VA & 6 & 7,496 & 1,249 \\
\hline 03175500 & Wolf Creek near Narrows, VA & 3 & 8,035 & 2,678 \\
\hline 03176500 & New River at Glen Lyn, VA & 4 & 7,496 & 1,874 \\
\hline 03177710 & Bluestone River at Falls Mills, VA & 5 & 4,792 & 958 \\
\hline 03207800 & Levisa Fork at Big Rock, VA & 6 & 8,402 & 1,400 \\
\hline 03208500 & Russell Fork at Haysi, VA & 4 & 8,402 & 2,101 \\
\hline 03478400 & Beaver Creek at Bristol, VA & 5 & 8,037 & 1,607 \\
\hline 03488000 & North Fork Holston River near Saltville, VA & 3 & 8,402 & 2,801 \\
\hline 03490000 & North Fork Holston River near Gate City, VA & 1 & 549 & 549 \\
\hline 03524000 & Clinch River at Cleveland, VA & 3 & 7,587 & 2,529 \\
\hline 03524500 & Guest River at Coeburn, VA & 2 & 427 & 214 \\
\hline 03527000 & Clinch River at Speers Ferry, VA & 6 & 4,384 & 731 \\
\hline 03529500 & Powell River at Big Stone Gap, VA & 3 & 4,384 & 1,461 \\
\hline \multirow[t]{2}{*}{03531500} & Powell River near Jonesville, VA & 3 & 6,941 & 2,314 \\
\hline & 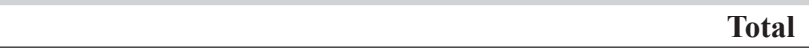 & 643 & $1,140,402$ & 1,774 \\
\hline
\end{tabular}




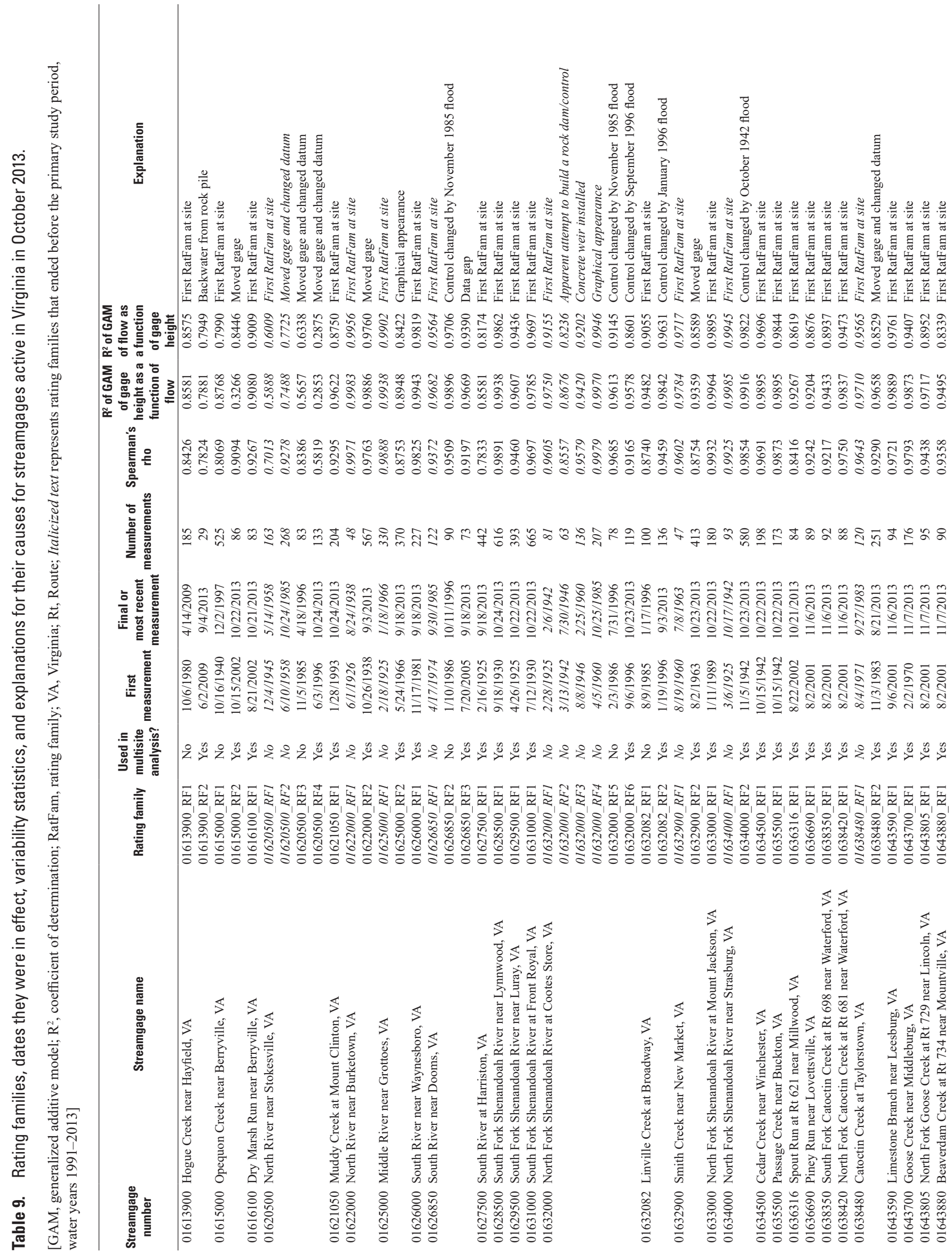




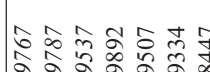

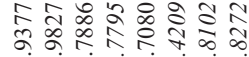

몽

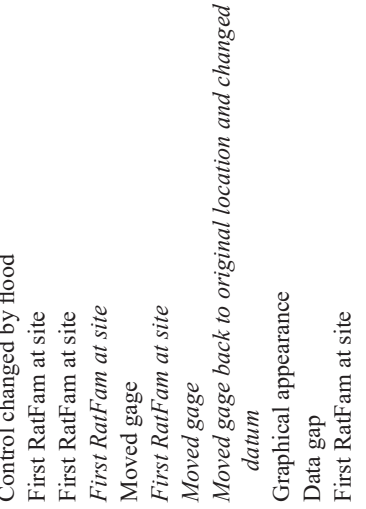

气 ะ

亳

萡 章。

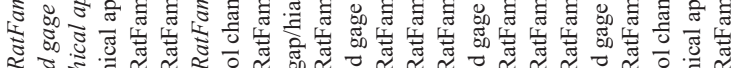

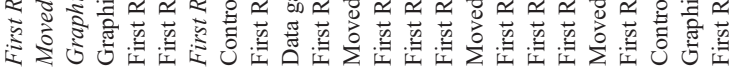

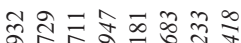

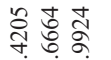

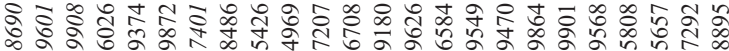

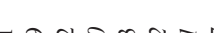

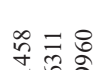

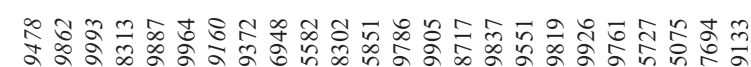

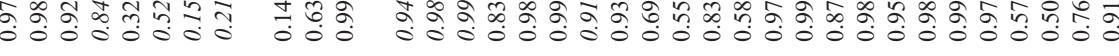

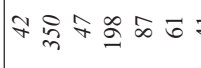

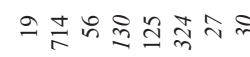

$\pi \overline{\mathrm{C}}^{3}$

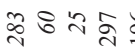

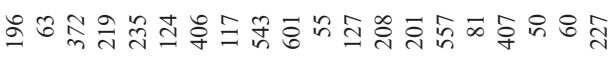

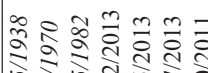

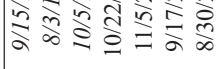

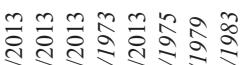

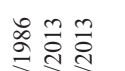

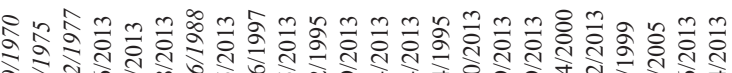

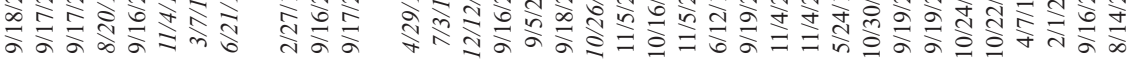

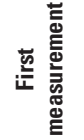

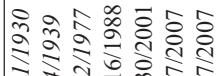

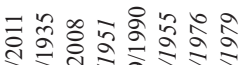

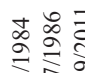

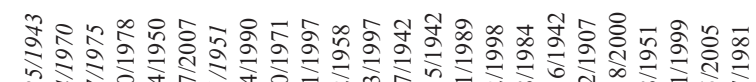

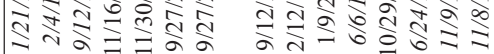

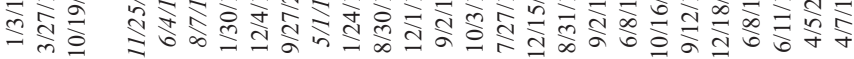

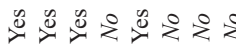

元串串

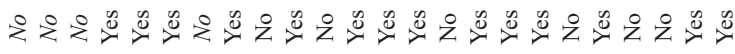

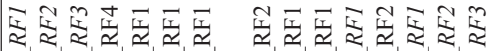

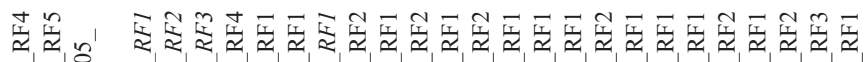

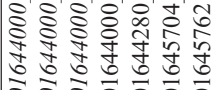

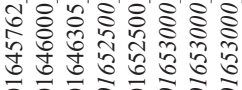

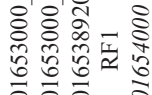
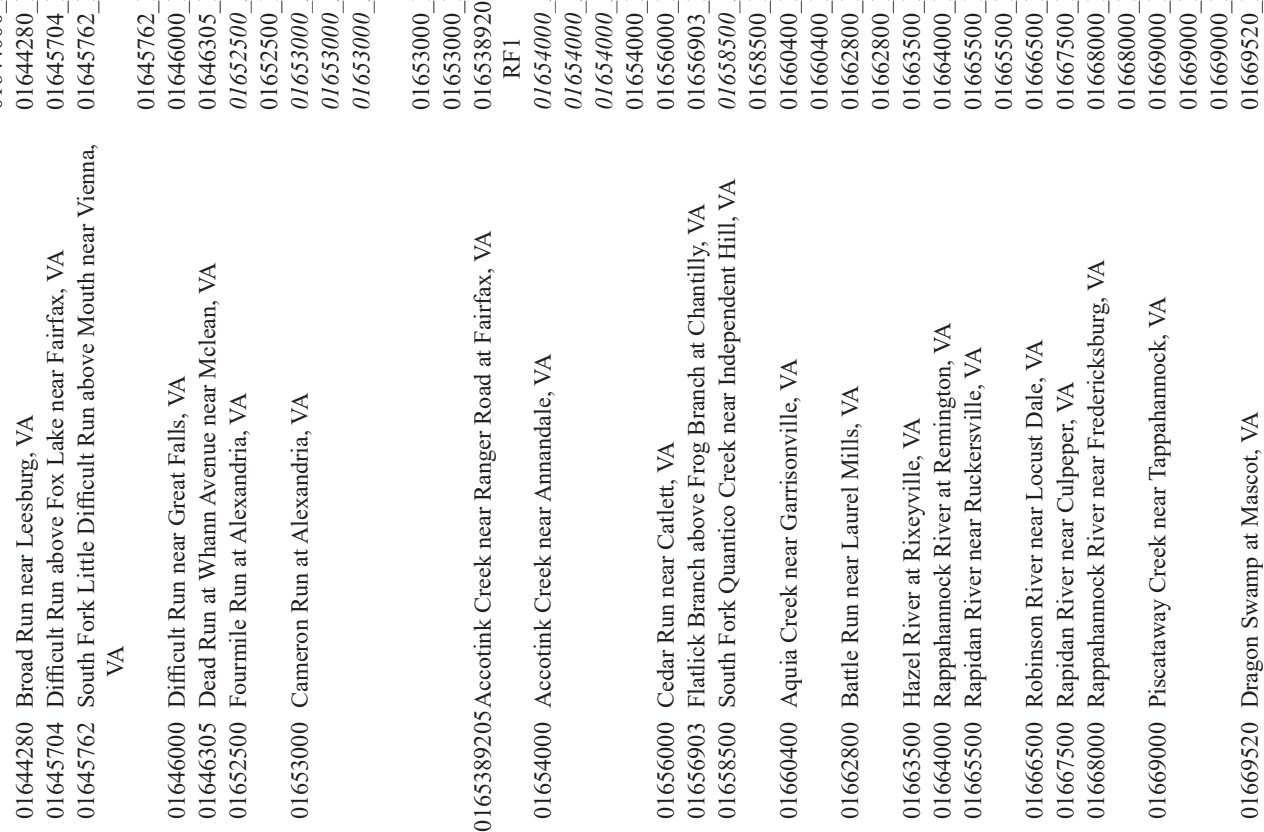

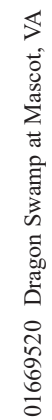




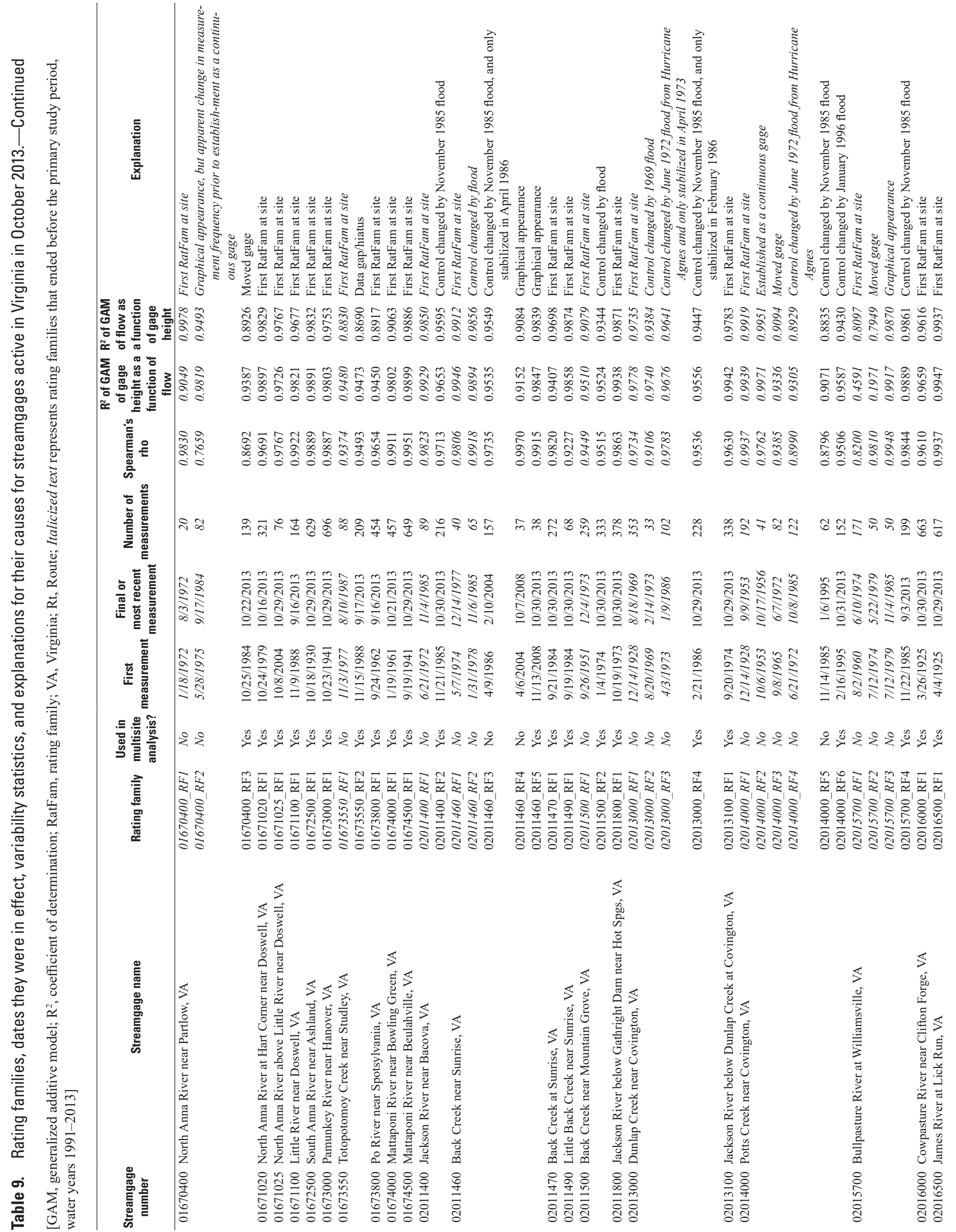




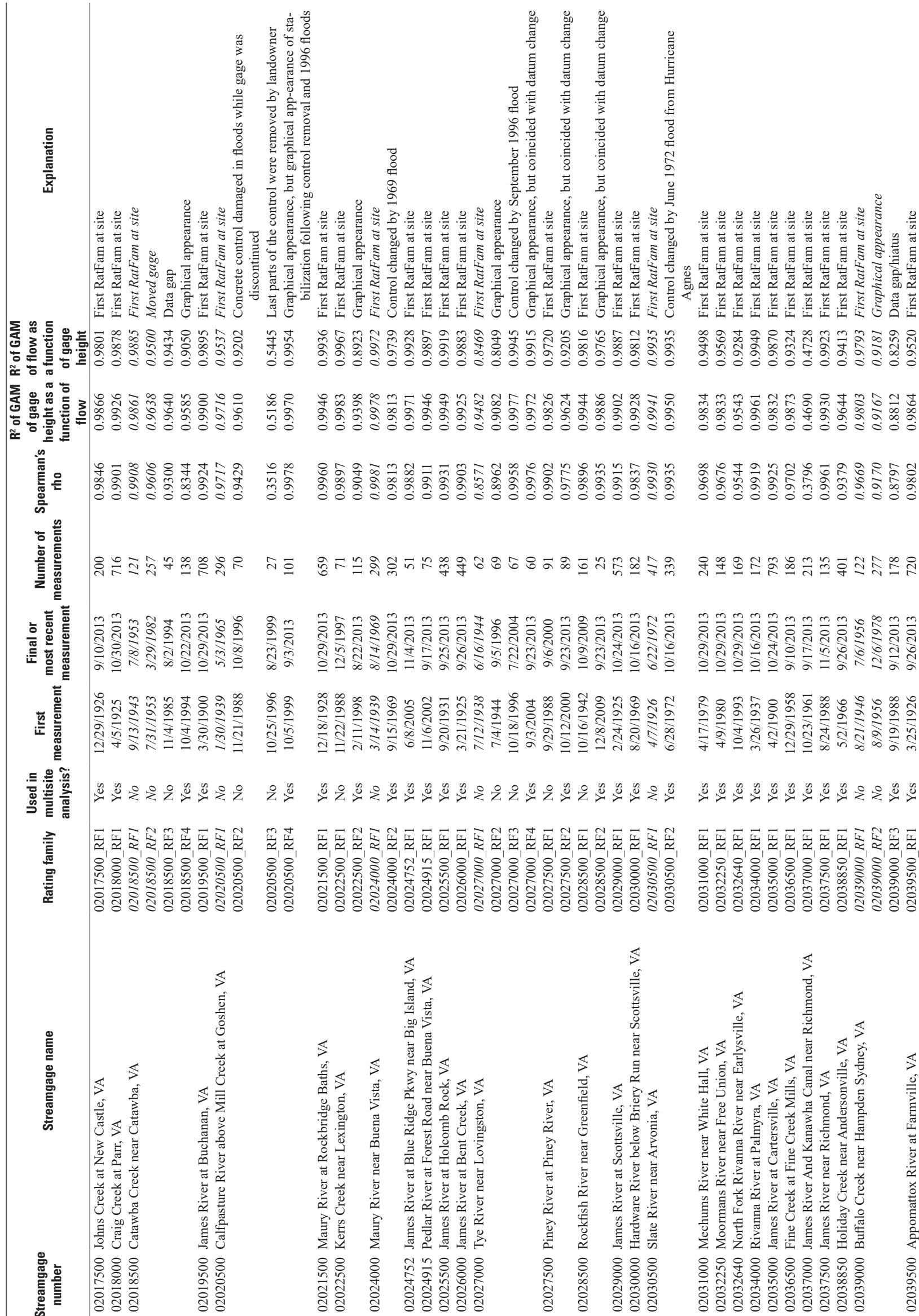




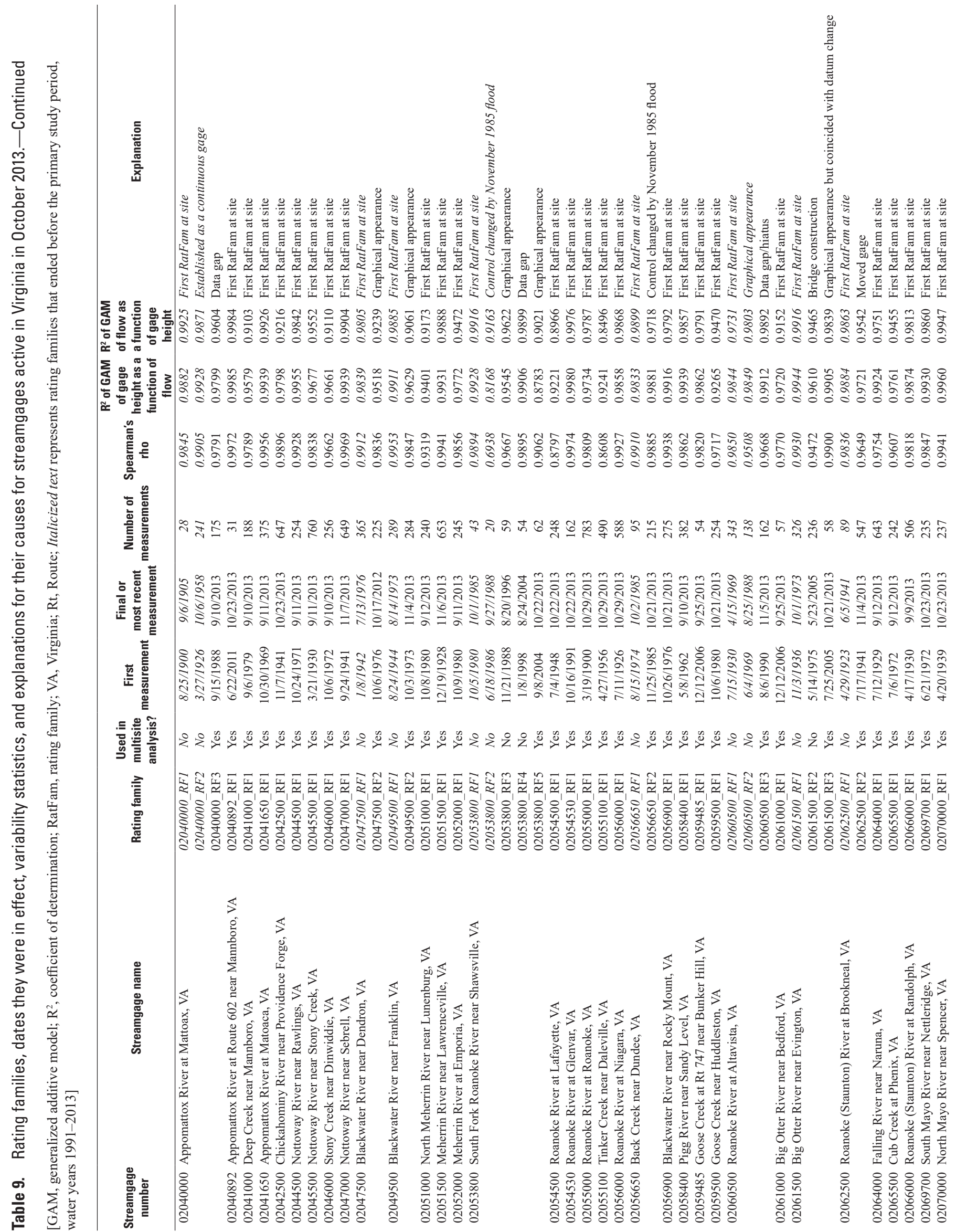




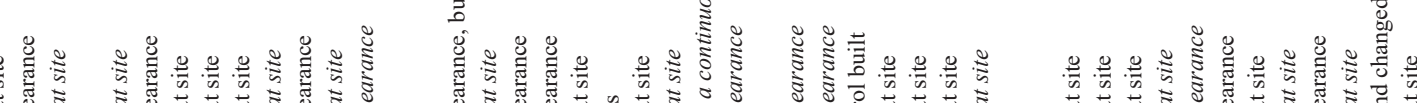

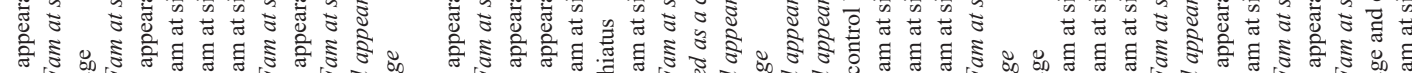
可 उ

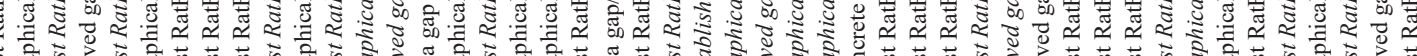

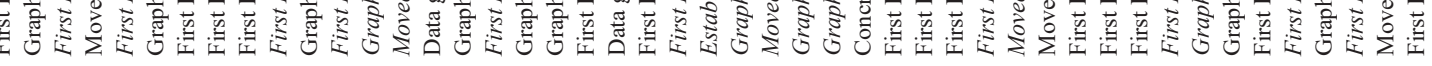

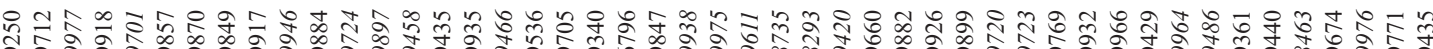

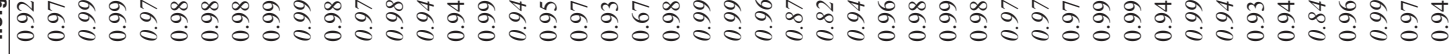

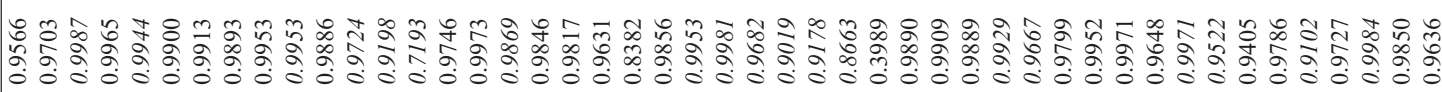

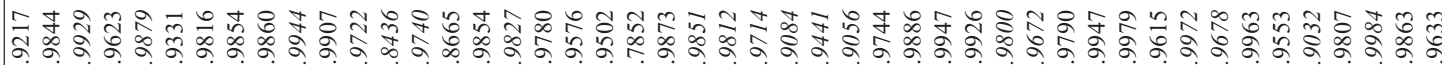

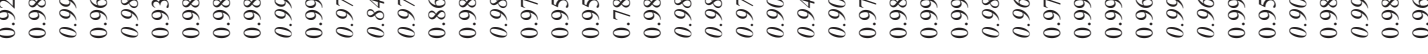

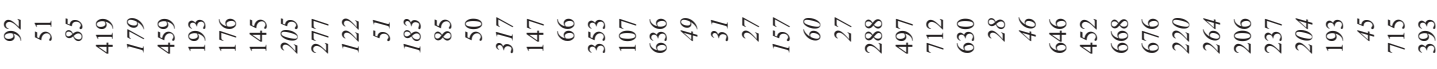

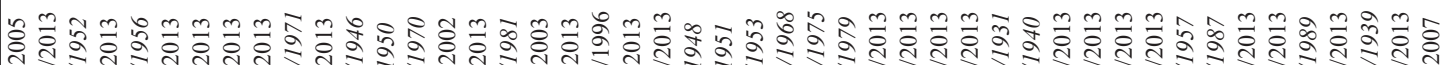

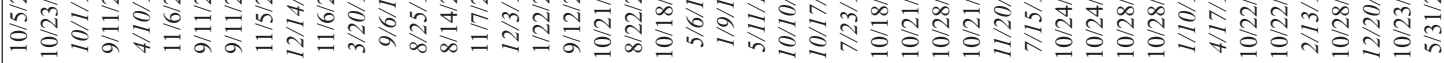

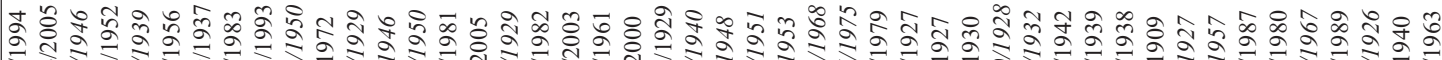

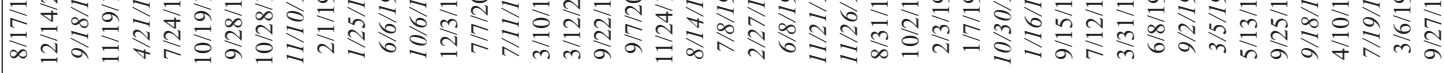

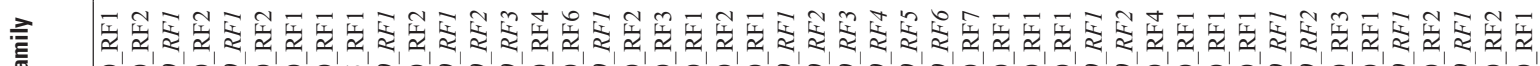

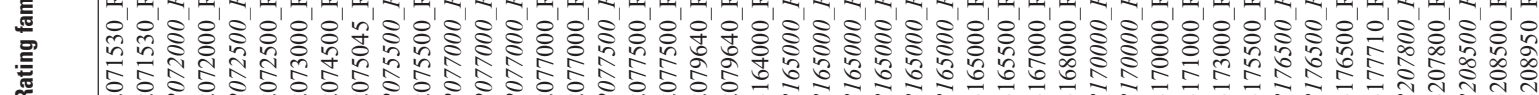
舟 


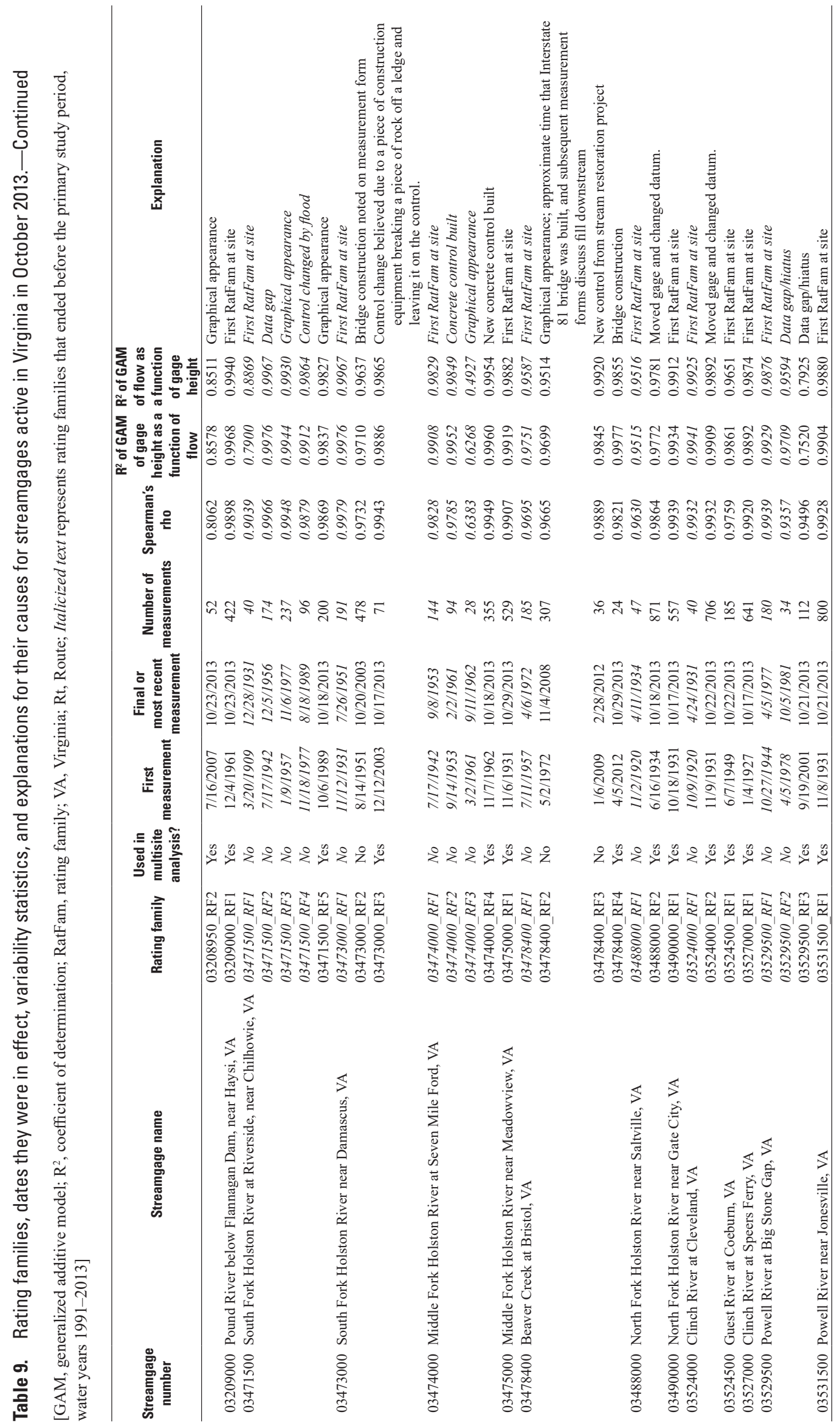




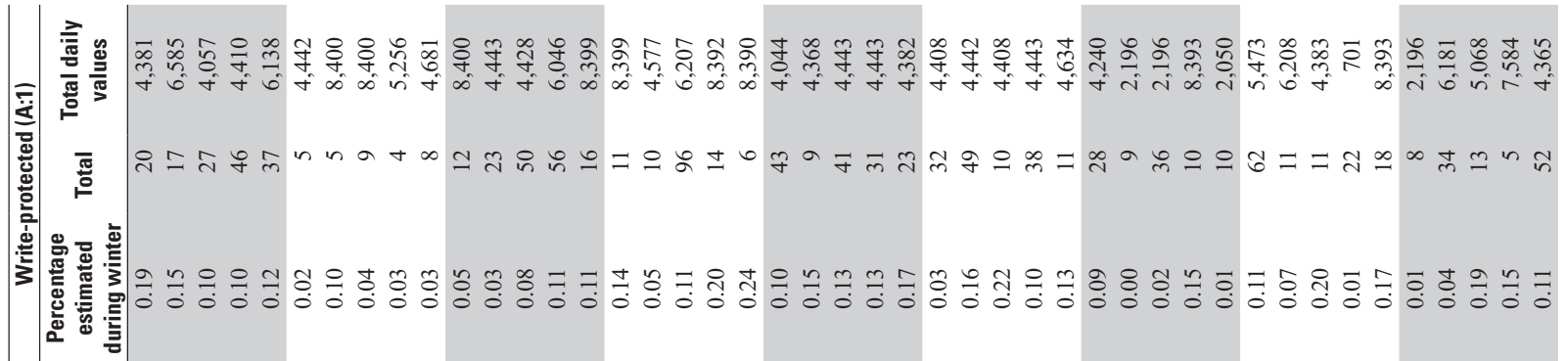

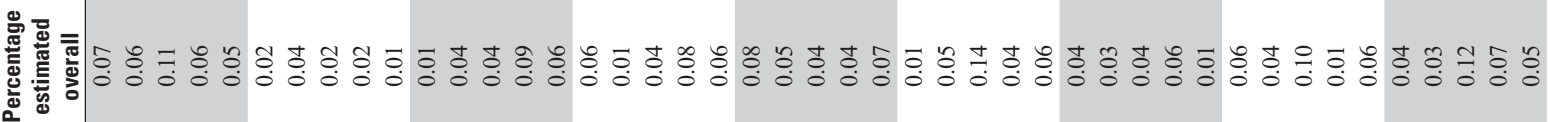

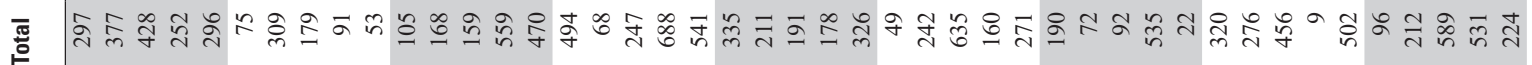
这 率 घे

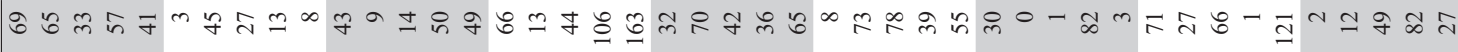

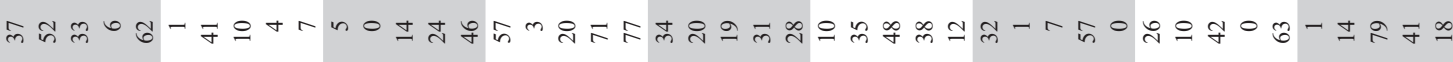

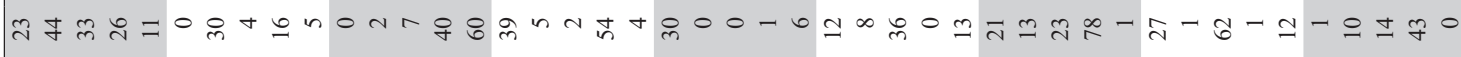

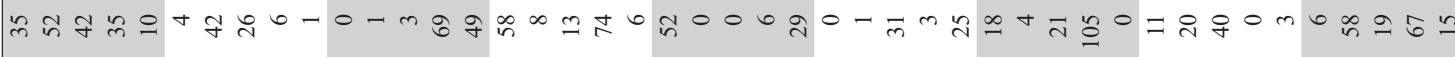

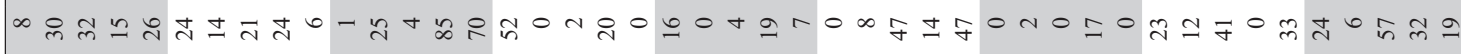

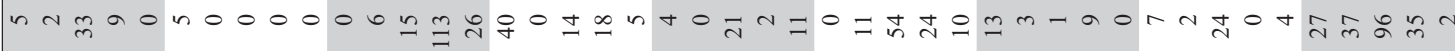

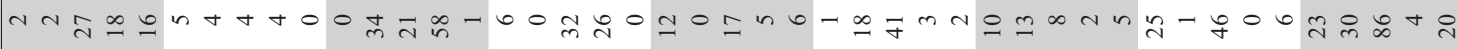

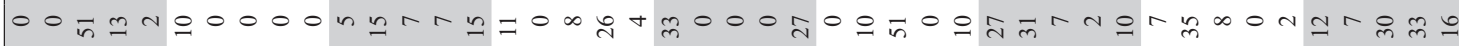

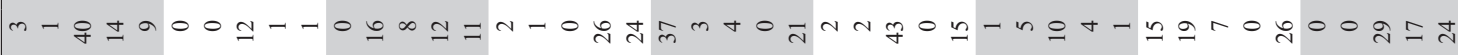

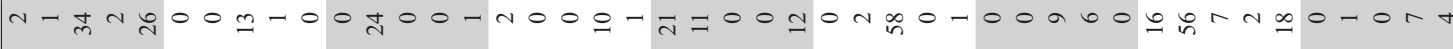

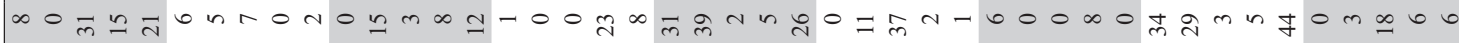

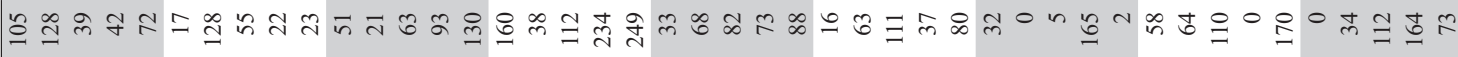
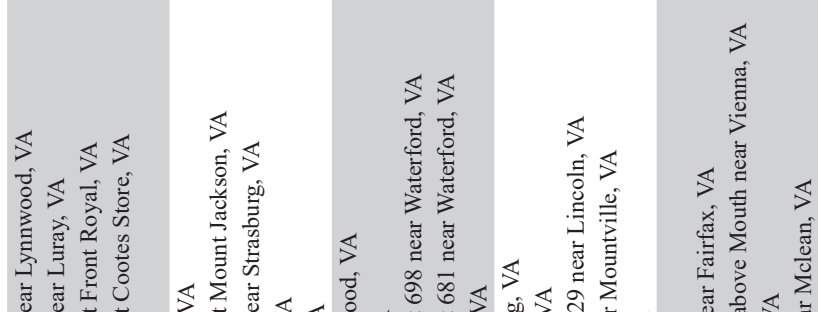

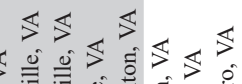

密

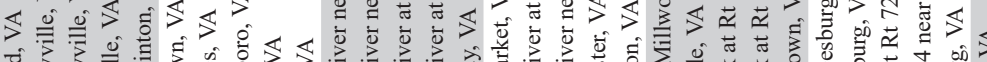

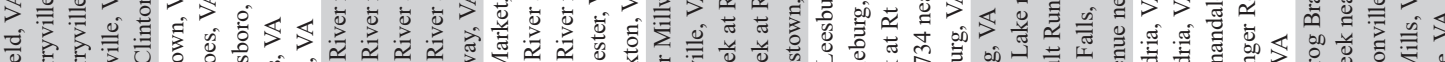

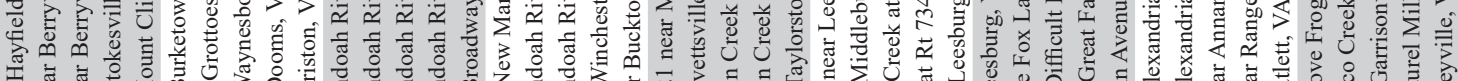

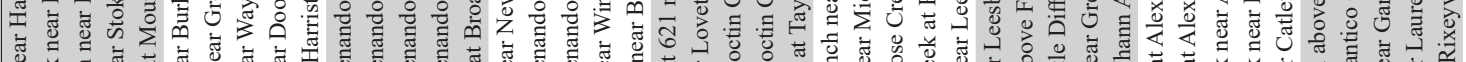

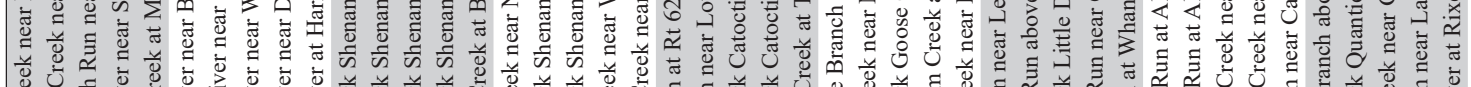

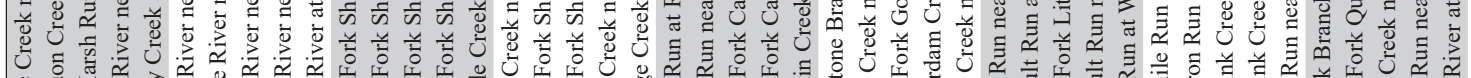

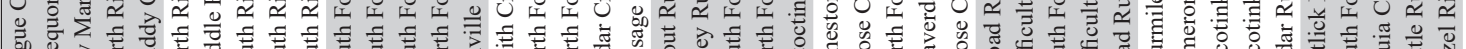

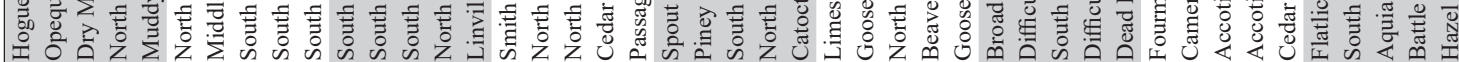




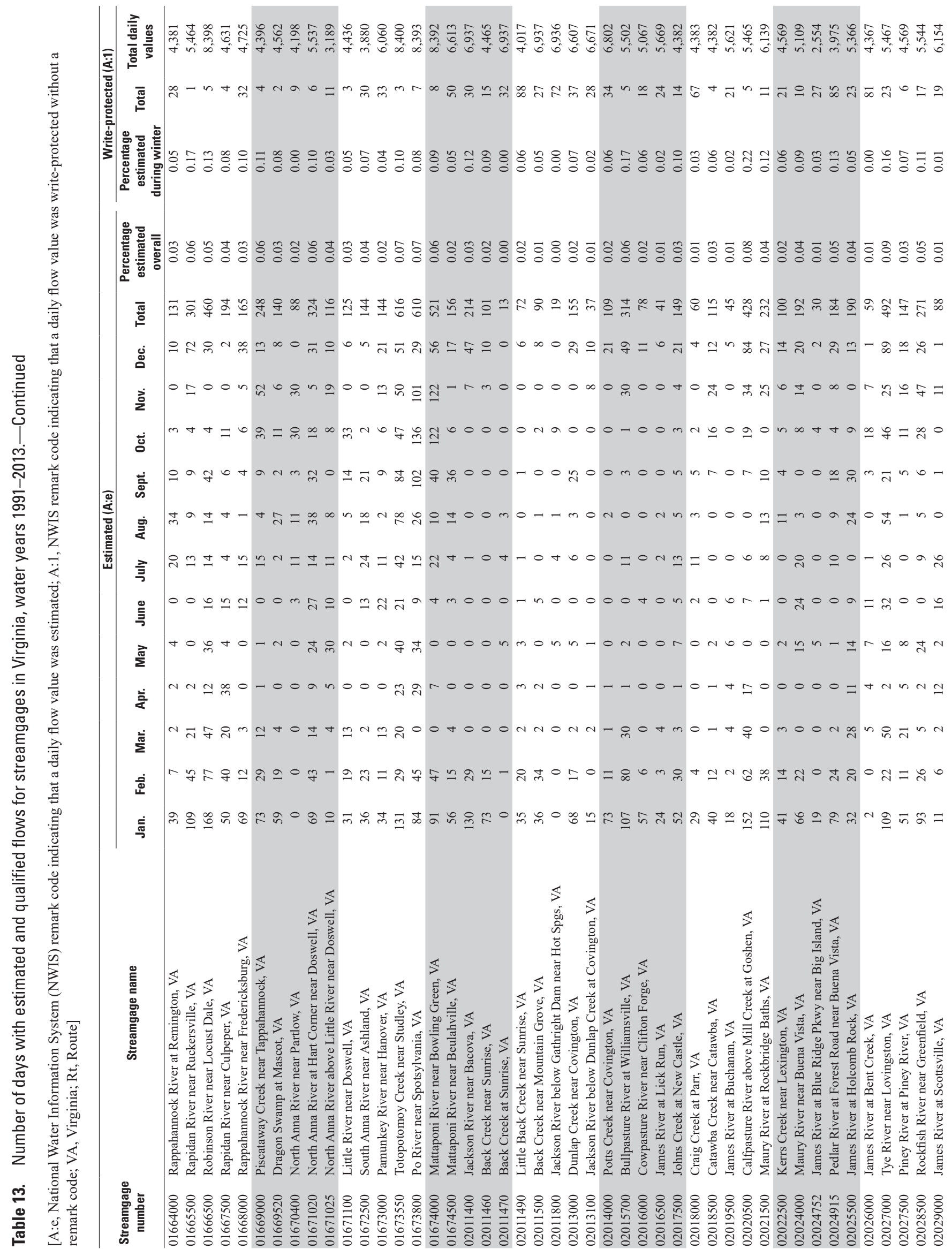




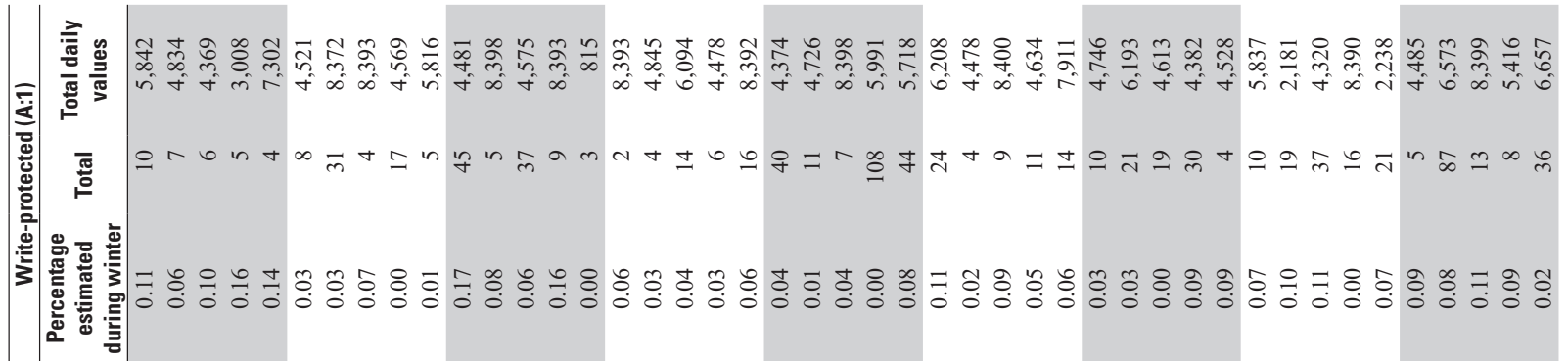

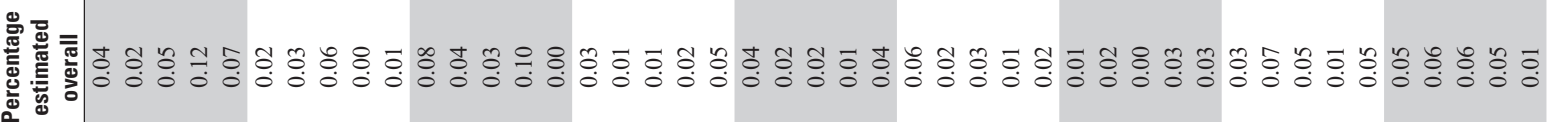

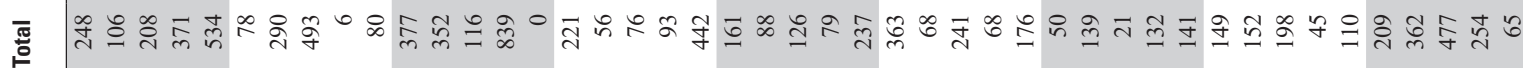

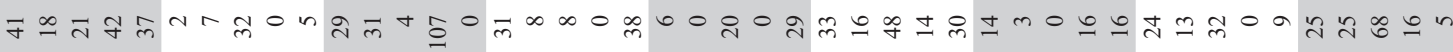

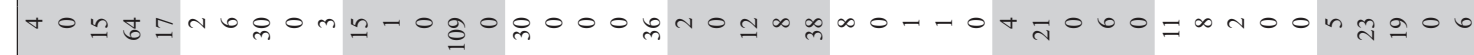

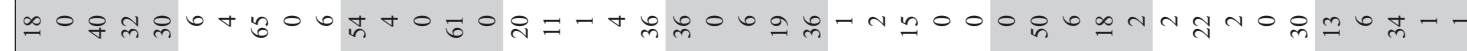

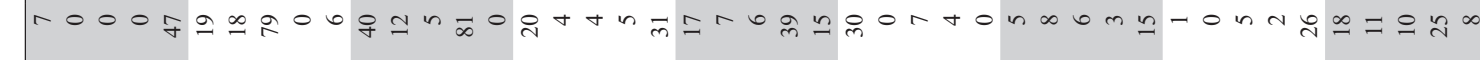
g) maㅏ t

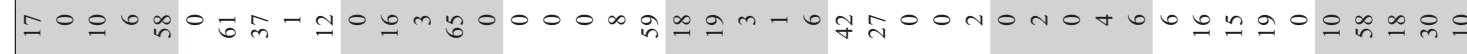

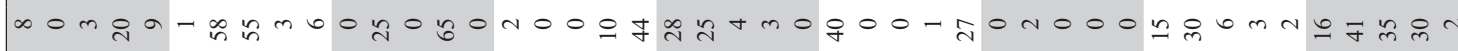
I0ori

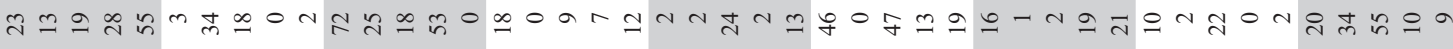

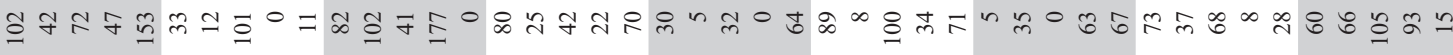

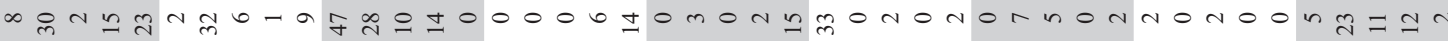
m-nza

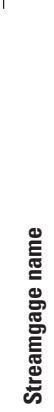

$\$$

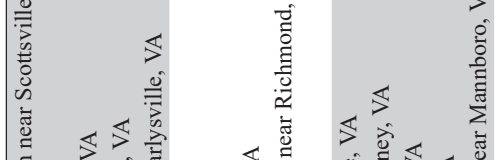

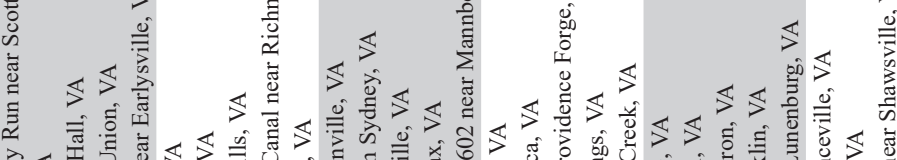

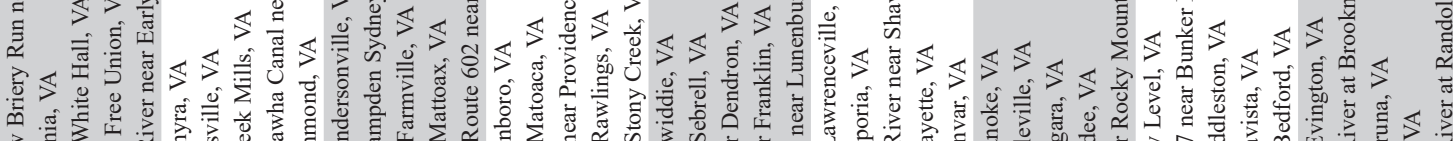

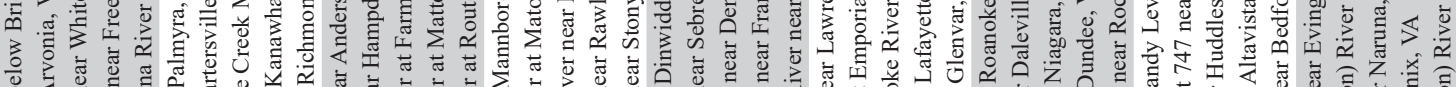

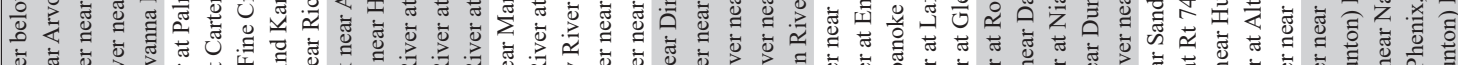

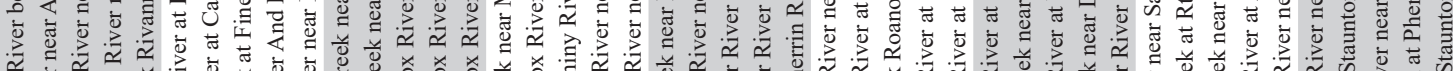

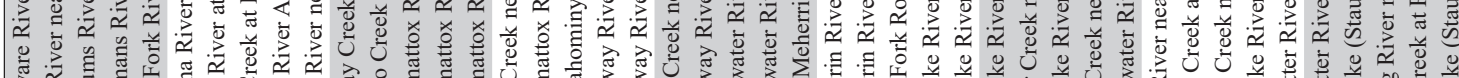

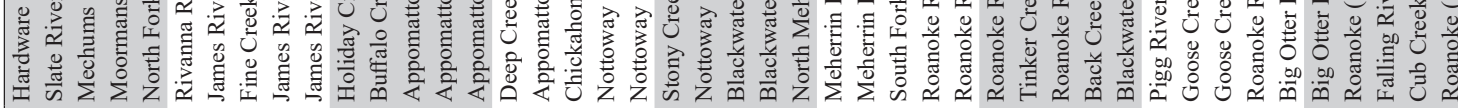

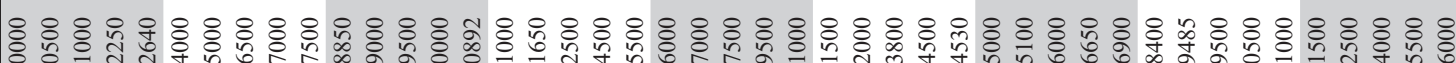
W 


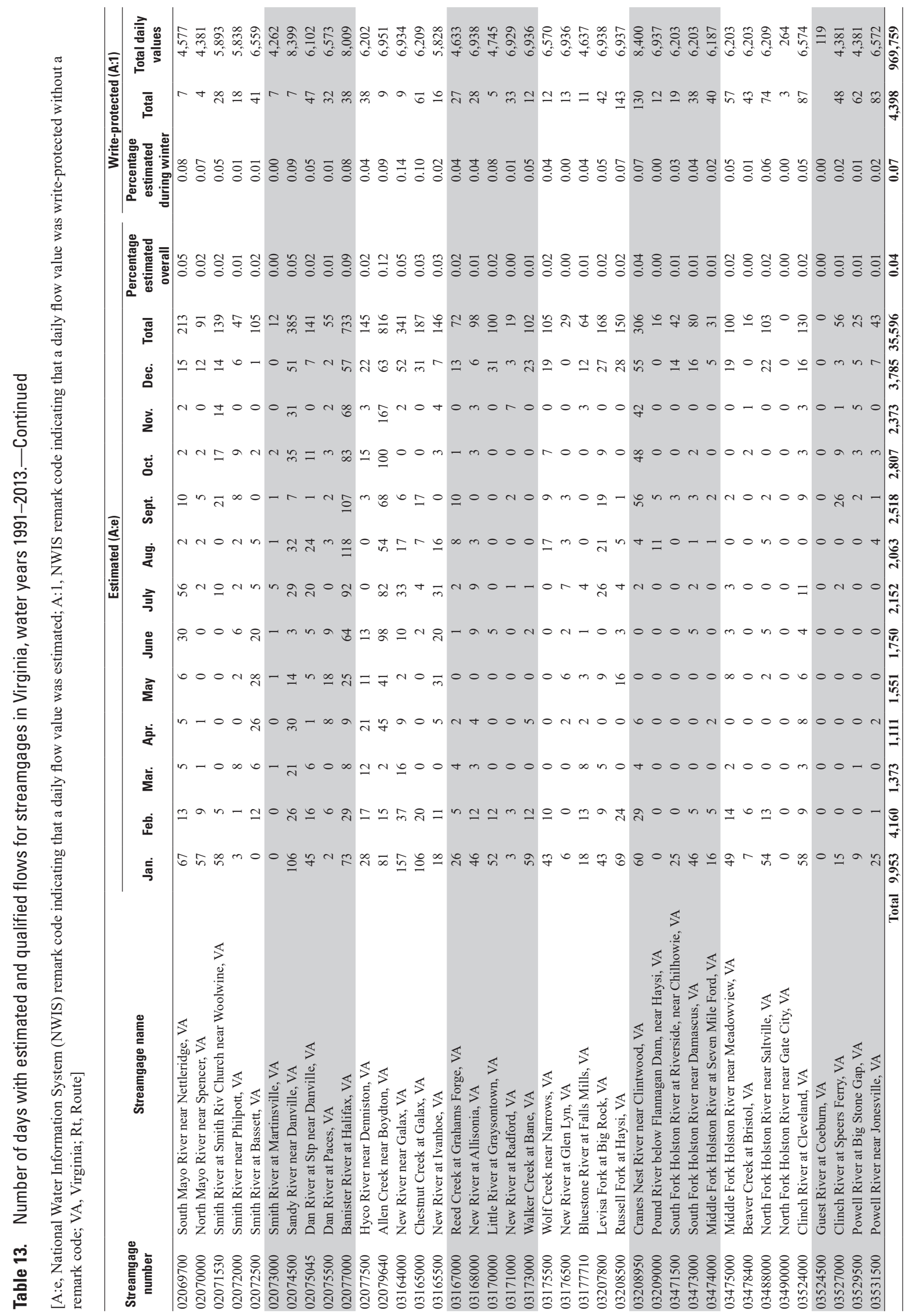


Table 19. Number of comparisons of directly measured flow to the rating in effect at the time of measurement relative to divergence thresholds for streamgages in Virginia, water years 1991-2013.

$[\Delta \mathrm{Q}$, incidents of difference in flow; \%, percent; >, greater than; <, less than; unexplained, lacking an explanation or description of measurement quality in National Water Information System; VA, Virginia; Rt, Route]

\begin{tabular}{|c|c|c|c|c|c|c|c|}
\hline $\begin{array}{c}\text { Streamgage } \\
\text { number }\end{array}$ & Streamgage name & $\begin{array}{c}\text { Number of } \\
\text { measurement- } \\
\text { rating } \\
\text { comparisons }\end{array}$ & $\begin{array}{l}\text { Number, } \\
\Delta \mathbf{0}>\mathbf{8} \%\end{array}$ & $\begin{array}{c}\text { Number, } \\
\Delta \mathbf{0}>\mathbf{8 \%}, \\
\text { unexplained }\end{array}$ & $\begin{array}{c}\text { Number, } \\
5 \%>\Delta \mathbf{0}<\mathbf{8 \%}\end{array}$ & $\begin{array}{c}\text { Number, } \\
5 \%>\Delta \mathbf{0}<\mathbf{8} \%, \\
\text { unexplained }\end{array}$ & $\begin{array}{c}\text { Percentage of } \\
\text { unexplained } \\
\Delta \text { Qs }\end{array}$ \\
\hline 01613900 & Hogue Creek near Hayfield, VA & 85 & 2 & 0 & 10 & 1 & 0.01 \\
\hline 01615000 & Opequon Creek near Berryville, VA & 145 & 9 & 2 & 19 & 2 & 0.03 \\
\hline 01616100 & Dry Marsh Run near Berryville, VA & 82 & 6 & 3 & 19 & 0 & 0.04 \\
\hline 01620500 & North River near Stokesville, VA & 95 & 10 & 4 & 23 & 0 & 0.04 \\
\hline 01621050 & Muddy Creek at Mount Clinton, VA & 123 & 10 & 4 & 30 & 2 & 0.05 \\
\hline 01622000 & North River near Burketown, VA & 79 & 1 & 1 & 3 & 1 & 0.03 \\
\hline 01625000 & Middle River near Grottoes, VA & 160 & 2 & 1 & 6 & 0 & 0.01 \\
\hline 01626000 & South River near Waynesboro, VA & 166 & 1 & 0 & 10 & 1 & 0.01 \\
\hline 01626850 & South River near Dooms, VA & 120 & 3 & 0 & 6 & 0 & 0.00 \\
\hline 01627500 & South River at Harriston, VA & 98 & 2 & 0 & 6 & 0 & 0.00 \\
\hline 01628500 & South Fork Shenandoah River near Lynnwood, VA & 155 & 2 & 0 & 8 & 1 & 0.01 \\
\hline 01629500 & South Fork Shenandoah River near Luray, VA & 86 & 1 & 0 & 9 & 0 & 0.00 \\
\hline 01631000 & South Fork Shenandoah River at Front Royal, VA & 93 & 5 & 0 & 20 & 1 & 0.01 \\
\hline 01632000 & North Fork Shenandoah River at Cootes Store, VA & 119 & 9 & 1 & 28 & 1 & 0.02 \\
\hline 01632082 & Linville Creek at Broadway, VA & 190 & 7 & 0 & 16 & 3 & 0.02 \\
\hline 01632900 & Smith Creek near New Market, VA & 190 & 1 & 0 & 7 & 0 & 0.00 \\
\hline 01633000 & North Fork Shenandoah River at Mount Jackson, VA & 88 & 1 & 1 & 3 & 2 & 0.03 \\
\hline 01634000 & North Fork Shenandoah River near Strasburg, VA & 137 & 6 & 2 & 17 & 1 & 0.02 \\
\hline 01634500 & Cedar Creek near Winchester, VA & 178 & 9 & 0 & 19 & 3 & 0.02 \\
\hline 01635500 & Passage Creek near Buckton, VA & 155 & 9 & 2 & 26 & 2 & 0.03 \\
\hline 01636316 & Spout Run at Rt 621 near Millwood, VA & 82 & 2 & 1 & 10 & 0 & 0.01 \\
\hline 01636690 & Piney Run near Lovettsville, VA & 86 & 11 & 5 & 18 & 2 & 0.08 \\
\hline 01638350 & South Fork Catoctin Creek at Rt 698 near Waterford, VA & 92 & 7 & 1 & 23 & 0 & 0.01 \\
\hline 01638420 & North Fork Catoctin Creek at Rt 681 near Waterford, VA & 88 & 6 & 2 & 13 & 1 & 0.03 \\
\hline 01638480 & Catoctin Creek at Taylorstown, VA & 99 & 7 & 3 & 10 & 2 & 0.05 \\
\hline 01643590 & Limestone Branch near Leesburg, VA & 93 & 5 & 2 & 16 & 1 & 0.03 \\
\hline 01643700 & Goose Creek near Middleburg, VA & 89 & 8 & 3 & 16 & 1 & 0.04 \\
\hline 01643805 & North Fork Goose Creek at Rt 729 near Lincoln, VA & 93 & 5 & 0 & 17 & 1 & 0.01 \\
\hline 01643880 & Beaverdam Creek at Rt 734 near Mountville, VA & 89 & 8 & 0 & 17 & 4 & 0.04 \\
\hline 01644000 & Goose Creek near Leesburg, VA & 98 & 4 & 1 & 10 & 0 & 0.01 \\
\hline 01644280 & Broad Run near Leesburg, VA & 83 & 9 & 4 & 18 & 0 & 0.05 \\
\hline 01645704 & Difficult Run above Fox Lake near Fairfax, VA & 61 & 9 & 1 & 13 & 0 & 0.02 \\
\hline 01645762 & South Fork Little Difficult Run above Mouth near Vienna, VA & 60 & 9 & 2 & 14 & 0 & 0.03 \\
\hline 01646000 & Difficult Run near Great Falls, VA & 181 & 10 & 4 & 20 & 2 & 0.03 \\
\hline 01646305 & Dead Run at Whann Avenue near Mclean, VA & 56 & 14 & 3 & 18 & 0 & 0.05 \\
\hline 01652500 & Fourmile Run at Alexandria, VA & 120 & 8 & 2 & 16 & 1 & 0.03 \\
\hline 01653000 & Cameron Run at Alexandria, VA & 136 & 10 & 6 & 21 & 6 & 0.09 \\
\hline 01654000 & Accotink Creek near Annandale, VA & 95 & 5 & 2 & 19 & 3 & 0.05 \\
\hline 01656000 & Cedar Run near Catlett, VA & 171 & 9 & 2 & 16 & 1 & 0.02 \\
\hline 01656903 & Flatlick Branch above Frog Branch at Chantilly, VA & 63 & 12 & 2 & 15 & 1 & 0.05 \\
\hline 01658500 & South Fork Quantico Creek near Independent Hill, VA & 158 & 25 & 5 & 44 & 4 & 0.06 \\
\hline 01660400 & Aquia Creek near Garrisonville, VA & 122 & 16 & 2 & 32 & 5 & 0.06 \\
\hline 01662800 & Battle Run near Laurel Mills, VA & 163 & 6 & 3 & 17 & 4 & 0.04 \\
\hline 01663500 & Hazel River at Rixeyville, VA & 95 & 1 & 1 & 17 & 0 & 0.01 \\
\hline 01664000 & Rappahannock River at Remington, VA & 90 & 6 & 2 & 19 & 0 & 0.02 \\
\hline 01665500 & Rapidan River near Ruckersville, VA & 124 & 0 & 0 & 7 & 2 & 0.02 \\
\hline 01666500 & Robinson River near Locust Dale, VA & 198 & 2 & 1 & 7 & 0 & 0.01 \\
\hline 01667500 & Rapidan River near Culpeper, VA & 94 & 3 & 1 & 7 & 1 & 0.02 \\
\hline 01668000 & Rappahannock River near Fredericksburg, VA & 81 & 11 & 4 & 19 & 0 & 0.05 \\
\hline 01669000 & Piscataway Creek near Tappahannock, VA & 87 & 2 & 1 & 7 & 1 & 0.02 \\
\hline
\end{tabular}


Table 19. Number of comparisons of directly measured flow to the rating in effect at the time of measurement relative to divergence thresholds for streamgages in Virginia, water years 1991-2013.-Continued

$[\Delta \mathrm{Q}$, incidents of difference in flow; \%, percent; $>$, greater than; $<$, less than; unexplained, lacking an explanation or description of measurement quality in National Water Information System; VA, Virginia; Rt, Route]

\begin{tabular}{|c|c|c|c|c|c|c|c|}
\hline $\begin{array}{c}\text { Streamgage } \\
\text { number }\end{array}$ & Streamgage name & $\begin{array}{l}\text { Number of } \\
\text { measurement- } \\
\text { rating } \\
\text { comparisons }\end{array}$ & $\begin{array}{l}\text { Number, } \\
\Delta 0>8 \%\end{array}$ & $\begin{array}{c}\text { Number, } \\
\Delta \mathbf{0}>\mathbf{8 \%}, \\
\text { unexplained }\end{array}$ & $\begin{array}{c}\text { Number, } \\
5 \%>\Delta \mathbf{0}<\mathbf{8} \%\end{array}$ & $\begin{array}{c}\text { Number, } \\
5 \%>\Delta \mathbf{0}<8 \%, \\
\text { unexplained }\end{array}$ & $\begin{array}{c}\text { Percentage of } \\
\text { unexplained } \\
\Delta \mathbf{Q s}\end{array}$ \\
\hline 01669520 & Dragon Swamp at Mascot, VA & 83 & 2 & 0 & 3 & 0 & 0.00 \\
\hline 01670400 & North Anna River near Partlow, VA & 96 & 5 & 1 & 16 & 2 & 0.03 \\
\hline 01671020 & North Anna River at Hart Corner near Doswell, VA & 137 & 3 & 1 & 12 & 5 & 0.04 \\
\hline 01671025 & North Anna River above Little River near Doswell, VA & 75 & 8 & 5 & 34 & 3 & 0.11 \\
\hline 01671100 & Little River near Doswell, VA & 84 & 1 & 1 & 5 & 0 & 0.01 \\
\hline 01672500 & South Anna River near Ashland, VA & 88 & 5 & 2 & 16 & 0 & 0.02 \\
\hline 01673000 & Pamunkey River near Hanover, VA & 134 & 5 & 3 & 24 & 0 & 0.02 \\
\hline 01673550 & Totopotomoy Creek near Studley, VA & 195 & 10 & 2 & 22 & 10 & 0.06 \\
\hline 01673800 & Po River near Spotsylvania, VA & 169 & 7 & 6 & 19 & 2 & 0.05 \\
\hline 01674000 & Mattaponi River near Bowling Green, VA & 163 & 27 & 19 & 32 & 0 & 0.12 \\
\hline 01674500 & Mattaponi River near Beulahville, VA & 139 & 6 & 3 & 17 & 0 & 0.02 \\
\hline 02011400 & Jackson River near Bacova, VA & 148 & 4 & 3 & 6 & 1 & 0.03 \\
\hline 02011460 & Back Creek near Sunrise, VA & 97 & 3 & 1 & 8 & 1 & 0.02 \\
\hline 02011470 & Back Creek at Sunrise, VA & 176 & 10 & 6 & 25 & 6 & 0.07 \\
\hline 02011490 & Little Back Creek near Sunrise, VA & 31 & 6 & 4 & 7 & 0 & 0.13 \\
\hline 02011500 & Back Creek near Mountain Grove, VA & 161 & 8 & 3 & 16 & 2 & 0.03 \\
\hline 02011800 & Jackson River below Gathright Dam near Hot Spgs, VA & 205 & 21 & 12 & 45 & 4 & 0.08 \\
\hline 02013000 & Dunlap Creek near Covington, VA & 155 & 3 & 2 & 14 & 1 & 0.02 \\
\hline 02013100 & Jackson River below Dunlap Creek at Covington, VA & 151 & 2 & 1 & 12 & 5 & 0.04 \\
\hline 02014000 & Potts Creek near Covington, VA & 151 & 5 & 4 & 12 & 1 & 0.03 \\
\hline 02015700 & Bullpasture River at Williamsville, VA & 101 & 1 & 0 & 4 & 2 & 0.02 \\
\hline 02016000 & Cowpasture River near Clifton Forge, VA & 108 & 3 & 1 & 8 & 1 & 0.02 \\
\hline 02016500 & James River at Lick Run, VA & 124 & 2 & 1 & 5 & 2 & 0.02 \\
\hline 02017500 & Johns Creek at New Castle, VA & 82 & 3 & 0 & 6 & 1 & 0.01 \\
\hline 02018000 & Craig Creek at Parr, VA & 102 & 0 & 0 & 4 & 0 & 0.00 \\
\hline 02018500 & Catawba Creek near Catawba, VA & 83 & 4 & 2 & 10 & 0 & 0.02 \\
\hline 02019500 & James River at Buchanan, VA & 119 & 0 & 0 & 2 & 0 & 0.00 \\
\hline 02020500 & Calfpasture River above Mill Creek at Goshen, VA & 108 & 1 & 0 & 5 & 0 & 0.00 \\
\hline 02021500 & Maury River at Rockbridge Baths, VA & 111 & 3 & 1 & 27 & 5 & 0.05 \\
\hline 02022500 & Kerrs Creek near Lexington, VA & 92 & 4 & 3 & 12 & 3 & 0.07 \\
\hline 02024000 & Maury River near Buena Vista, VA & 91 & 1 & 1 & 13 & 0 & 0.01 \\
\hline 02024752 & James River at Blue Ridge Pkwy near Big Island, VA & 42 & 1 & 1 & 8 & 0 & 0.02 \\
\hline 02024915 & Pedlar River at Forest Road near Buena Vista, VA & 74 & 0 & 0 & 8 & 1 & 0.01 \\
\hline 02025500 & James River at Holcomb Rock, VA & 83 & 10 & 6 & 18 & 0 & 0.07 \\
\hline 02026000 & James River at Bent Creek, VA & 57 & 3 & 1 & 10 & 0 & 0.02 \\
\hline 02027000 & Tye River near Lovingston, VA & 106 & 2 & 2 & 5 & 2 & 0.04 \\
\hline 02027500 & Piney River at Piney River, VA & 86 & 1 & 1 & 3 & 2 & 0.03 \\
\hline 02028500 & Rockfish River near Greenfield, VA & 109 & 1 & 1 & 9 & 2 & 0.03 \\
\hline 02029000 & James River at Scottsville, VA & 96 & 1 & 0 & 15 & 0 & 0.00 \\
\hline 02030000 & Hardware River below Briery Run near Scottsville, VA & 127 & 2 & 2 & 15 & 5 & 0.06 \\
\hline 02030500 & Slate River near Arvonia, VA & 119 & 1 & 0 & 7 & 1 & 0.01 \\
\hline 02031000 & Mechums River near White Hall, VA & 97 & 3 & 1 & 8 & 1 & 0.02 \\
\hline 02032250 & Moormans River near Free Union, VA & 73 & 5 & 2 & 9 & 1 & 0.04 \\
\hline 02032640 & North Fork Rivanna River near Earlysville, VA & 168 & 11 & 8 & 21 & 5 & 0.08 \\
\hline 02034000 & Rivanna River at Palmyra, VA & 90 & 3 & 1 & 8 & 3 & 0.04 \\
\hline 02035000 & James River at Cartersville, VA & 178 & 29 & 19 & 45 & 4 & 0.13 \\
\hline 02036500 & Fine Creek at Fine Creek Mills, VA & 165 & 10 & 7 & 25 & 2 & 0.05 \\
\hline 02037000 & James River And Kanawha Canal near Richmond, VA & 117 & 6 & 0 & 8 & 1 & 0.01 \\
\hline 02037500 & James River near Richmond, VA & 110 & 5 & 0 & 11 & 1 & 0.01 \\
\hline 02038850 & Holiday Creek near Andersonville, VA & 94 & 6 & 3 & 26 & 0 & 0.03 \\
\hline
\end{tabular}


Table 19. Number of comparisons of directly measured flow to the rating in effect at the time of measurement relative to divergence thresholds for streamgages in Virginia, water years 1991-2013.-Continued

$[\Delta \mathrm{Q}$, incidents of difference in flow; \%, percent; $>$, greater than; $<$, less than; unexplained, lacking an explanation or description of measurement quality in National Water Information System; VA, Virginia; Rt, Route]

\begin{tabular}{|c|c|c|c|c|c|c|c|}
\hline $\begin{array}{c}\text { Streamgage } \\
\text { number }\end{array}$ & Streamgage name & $\begin{array}{c}\text { Number of } \\
\text { measurement- } \\
\text { rating } \\
\text { comparisons }\end{array}$ & $\begin{array}{l}\text { Number, } \\
\Delta \mathbf{Q}>\mathbf{8 \%}\end{array}$ & $\begin{array}{c}\text { Number, } \\
\Delta \mathbf{0}>\mathbf{8 \%}, \\
\text { unexplained }\end{array}$ & $\begin{array}{c}\text { Number, } \\
\mathbf{5 \%} \% \Delta \mathbf{0}<\mathbf{8} \%\end{array}$ & $\begin{array}{c}\text { Number, } \\
\mathbf{5 \%}>\Delta \mathbf{0}<\mathbf{8} \%, \\
\text { unexplained }\end{array}$ & $\begin{array}{c}\text { Percentage of } \\
\text { unexplained } \\
\Delta \mathbf{0 s}\end{array}$ \\
\hline 02039000 & Buffalo Creek near Hampden Sydney, VA & 164 & 3 & 1 & 4 & 1 & 0.01 \\
\hline 02039500 & Appomattox River at Farmville, VA & 89 & 1 & 1 & 8 & 1 & 0.02 \\
\hline 02040000 & Appomattox River at Mattoax, VA & 160 & 2 & 1 & 17 & 3 & 0.03 \\
\hline 02040892 & Appomattox River at Route 602 near Mannboro, VA & 30 & 2 & 0 & 3 & 0 & 0.00 \\
\hline 02041000 & Deep Creek near Mannboro, VA & 170 & 6 & 3 & 14 & 3 & 0.04 \\
\hline 02041650 & Appomattox River at Matoaca, VA & 95 & 5 & 3 & 19 & 0 & 0.03 \\
\hline 02042500 & Chickahominy River near Providence Forge, VA & 145 & 12 & 6 & 32 & 1 & 0.05 \\
\hline 02044500 & Nottoway River near Rawlings, VA & 94 & 2 & 0 & 11 & 1 & 0.01 \\
\hline 02045500 & Nottoway River near Stony Creek, VA & 175 & 3 & 2 & 11 & 3 & 0.03 \\
\hline 02046000 & Stony Creek near Dinwiddie, VA & 88 & 2 & 2 & 8 & 2 & 0.05 \\
\hline 02047000 & Nottoway River near Sebrell, VA & 94 & 4 & 2 & 18 & 0 & 0.02 \\
\hline 02047500 & Blackwater River near Dendron, VA & 166 & 31 & 2 & 38 & 3 & 0.03 \\
\hline 02049500 & Blackwater River near Franklin, VA & 136 & 29 & 3 & 40 & 0 & 0.02 \\
\hline 02051000 & North Meherrin River near Lunenburg, VA & 122 & 8 & 4 & 17 & 4 & 0.07 \\
\hline 02051500 & Meherrin River near Lawrenceville, VA & 129 & 9 & 1 & 21 & 4 & 0.04 \\
\hline 02052000 & Meherrin River at Emporia, VA & 88 & 7 & 2 & 9 & 1 & 0.03 \\
\hline 02053800 & South Fork Roanoke River near Shawsville, VA & 169 & 6 & 3 & 12 & 2 & 0.03 \\
\hline 02054500 & Roanoke River at Lafayette, VA & 89 & 1 & 0 & 9 & 4 & 0.04 \\
\hline 02054530 & Roanoke River at Glenvar, VA & 160 & 2 & 1 & 8 & 5 & 0.04 \\
\hline 02055000 & Roanoke River at Roanoke, VA & 103 & 5 & 5 & 7 & 1 & 0.06 \\
\hline 02055100 & Tinker Creek near Daleville, VA & 135 & 7 & 5 & 13 & 2 & 0.05 \\
\hline 02056000 & Roanoke River at Niagara, VA & 89 & 2 & 1 & 3 & 1 & 0.02 \\
\hline 02056650 & Back Creek near Dundee, VA & 88 & 0 & 0 & 8 & 4 & 0.05 \\
\hline 02056900 & Blackwater River near Rocky Mount, VA & 83 & 2 & 1 & 5 & 1 & 0.02 \\
\hline 02058400 & Pigg River near Sandy Level, VA & 114 & 3 & 2 & 17 & 1 & 0.03 \\
\hline 02059485 & Goose Creek at Rt 747 near Bunker Hill, VA & 47 & 0 & 0 & 1 & 1 & 0.02 \\
\hline 02059500 & Goose Creek near Huddleston, VA & 88 & 2 & 0 & 7 & 1 & 0.01 \\
\hline 02060500 & Roanoke River at Altavista, VA & 160 & 3 & 3 & 23 & 4 & 0.04 \\
\hline 02061000 & Big Otter River near Bedford, VA & 51 & 5 & 4 & 8 & 1 & 0.10 \\
\hline 02061500 & Big Otter River near Evington, VA & 95 & 1 & 0 & 4 & 1 & 0.01 \\
\hline 02062500 & Roanoke (Staunton) River at Brookneal, VA & 134 & 8 & 1 & 19 & 1 & 0.01 \\
\hline 02064000 & Falling River near Naruna, VA & 161 & 3 & 1 & 8 & 1 & 0.01 \\
\hline 02065500 & Cub Creek at Phenix, VA & 110 & 6 & 2 & 7 & 1 & 0.03 \\
\hline 02066000 & Roanoke (Staunton) River at Randolph, VA & 138 & 12 & 5 & 26 & 2 & 0.05 \\
\hline 02069700 & South Mayo River near Nettleridge, VA & 84 & 2 & 1 & 6 & 2 & 0.04 \\
\hline 02070000 & North Mayo River near Spencer, VA & 78 & 2 & 1 & 6 & 2 & 0.04 \\
\hline 02071530 & Smith River at Smith Riv Church near Woolwine, VA & 117 & 4 & 1 & 13 & 8 & 0.08 \\
\hline 02072000 & Smith River near Philpott, VA & 116 & 4 & 1 & 13 & 3 & 0.03 \\
\hline 02072500 & Smith River at Bassett, VA & 140 & 3 & 1 & 17 & 1 & 0.01 \\
\hline 02073000 & Smith River at Martinsville, VA & 71 & 2 & 1 & 5 & 0 & 0.01 \\
\hline 02074500 & Sandy River near Danville, VA & 158 & 2 & 1 & 7 & 0 & 0.01 \\
\hline 02075045 & Dan River at Stp near Danville, VA & 122 & 10 & 1 & 24 & 0 & 0.01 \\
\hline 02075500 & Dan River at Paces, VA & 132 & 14 & 3 & 21 & 0 & 0.02 \\
\hline 02077000 & Banister River at Halifax, VA & 102 & 20 & 9 & 32 & 1 & 0.10 \\
\hline 02077500 & Hyco River near Denniston, VA & 122 & 5 & 0 & 13 & 0 & 0.00 \\
\hline 02079640 & Allen Creek near Boydton, VA & 153 & 8 & 4 & 20 & 1 & 0.03 \\
\hline 03164000 & New River near Galax, VA & 143 & 2 & 1 & 6 & 1 & 0.01 \\
\hline 03165000 & Chestnut Creek at Galax, VA & 134 & 5 & 4 & 9 & 1 & 0.04 \\
\hline 03165500 & New River at Ivanhoe, VA & 123 & 3 & 3 & 8 & 2 & 0.04 \\
\hline 03167000 & Reed Creek at Grahams Forge, VA & 102 & 0 & 0 & 0 & 0 & 0.00 \\
\hline
\end{tabular}


Table 19. Number of comparisons of directly measured flow to the rating in effect at the time of measurement relative to divergence thresholds for streamgages in Virginia, water years 1991-2013.-Continued

$[\Delta \mathrm{Q}$, incidents of difference in flow; \%, percent; >, greater than; <, less than; unexplained, lacking an explanation or description of measurement quality in National Water Information System; VA, Virginia; Rt, Route]

\begin{tabular}{|c|c|c|c|c|c|c|c|}
\hline $\begin{array}{l}\text { Streamgage } \\
\text { number }\end{array}$ & Streamgage name & $\begin{array}{c}\text { Number of } \\
\text { measurement- } \\
\text { rating } \\
\text { comparisons }\end{array}$ & $\begin{array}{l}\text { Number, } \\
\Delta \mathbf{Q}>\mathbf{8} \%\end{array}$ & $\begin{array}{c}\text { Number, } \\
\Delta \mathbf{0}>8 \%, \\
\text { unexplained }\end{array}$ & $\begin{array}{c}\text { Number, } \\
\mathbf{5 \%}>\Delta \mathbf{0}<\mathbf{8} \%\end{array}$ & $\begin{array}{c}\text { Number, } \\
\mathbf{5 \%}>\Delta \mathbf{0}<\mathbf{8 \%}, \\
\text { unexplained }\end{array}$ & $\begin{array}{c}\text { Percentage of } \\
\text { unexplained } \\
\Delta \mathbf{0 s}\end{array}$ \\
\hline 03168000 & New River at Allisonia, VA & 134 & 1 & 1 & 9 & 4 & 0.04 \\
\hline 03170000 & Little River at Graysontown, VA & 110 & 2 & 0 & 6 & 1 & 0.01 \\
\hline 03171000 & New River at Radford, VA & 128 & 3 & 1 & 10 & 1 & 0.02 \\
\hline 03173000 & Walker Creek at Bane, VA & 155 & 6 & 1 & 17 & 5 & 0.04 \\
\hline 03175500 & Wolf Creek near Narrows, VA & 146 & 3 & 1 & 9 & 2 & 0.02 \\
\hline 03176500 & New River at Glen Lyn, VA & 149 & 3 & 1 & 9 & 0 & 0.01 \\
\hline 03177710 & Bluestone River at Falls Mills, VA & 129 & 10 & 9 & 29 & 14 & 0.18 \\
\hline 03207800 & Levisa Fork at Big Rock, VA & 151 & 0 & 0 & 7 & 3 & 0.02 \\
\hline 03208500 & Russell Fork at Haysi, VA & 151 & 3 & 1 & 9 & 0 & 0.01 \\
\hline 03208950 & Cranes Nest River near Clintwood, VA & 186 & 21 & 11 & 29 & 2 & 0.07 \\
\hline 03209000 & Pound River below Flannagan Dam, near Haysi, VA & 140 & 5 & 2 & 9 & 1 & 0.02 \\
\hline 03471500 & South Fork Holston River at Riverside, near Chilhowie, VA & 142 & 5 & 3 & 7 & 0 & 0.02 \\
\hline 03473000 & South Fork Holston River near Damascus, VA & 126 & 2 & 1 & 10 & 3 & 0.03 \\
\hline 03474000 & Middle Fork Holston River at Seven Mile Ford, VA & 135 & 6 & 3 & 18 & 0 & 0.02 \\
\hline 03475000 & Middle Fork Holston River near Meadowview, VA & 140 & 2 & 1 & 9 & 2 & 0.02 \\
\hline 03478400 & Beaver Creek at Bristol, VA & 163 & 4 & 4 & 16 & 8 & 0.07 \\
\hline 03488000 & North Fork Holston River near Saltville, VA & 144 & 3 & 0 & 4 & 0 & 0.00 \\
\hline 03490000 & North Fork Holston River near Gate City, VA & 5 & 1 & 0 & 1 & 0 & 0.00 \\
\hline 03524000 & Clinch River at Cleveland, VA & 149 & 1 & 1 & 4 & 1 & 0.01 \\
\hline 03524500 & Guest River at Coeburn, VA & 2 & 0 & 0 & 0 & 0 & 0.00 \\
\hline 03527000 & Clinch River at Speers Ferry, VA & 101 & 0 & 0 & 7 & 2 & 0.02 \\
\hline 03529500 & Powell River at Big Stone Gap, VA & 109 & 3 & 2 & 7 & 1 & 0.03 \\
\hline 03531500 & Powell River near Jonesville, VA & 138 & 1 & 1 & 4 & 0 & 0.01 \\
\hline \multirow{2}{*}{\multicolumn{2}{|c|}{0165389205 Accotink Creek near Ranger Road at Fairfax, VA }} & 20 & 2 & 1 & 6 & 0 & 0.05 \\
\hline & & 20,380 & 1,063 & 451 & 2,482 & 287 & 0.04 \\
\hline
\end{tabular}




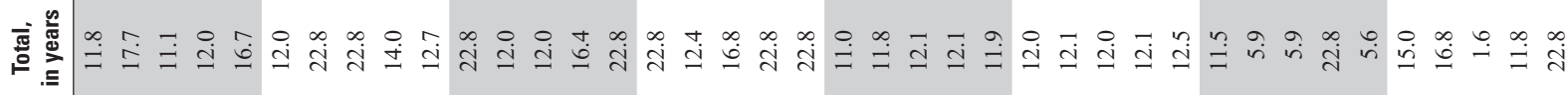

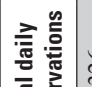

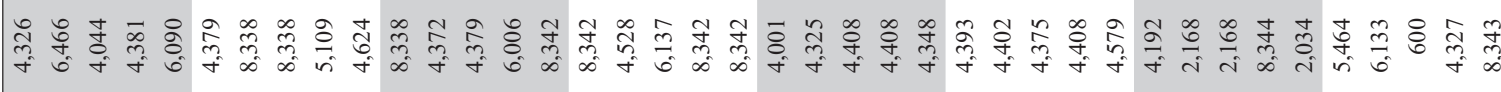

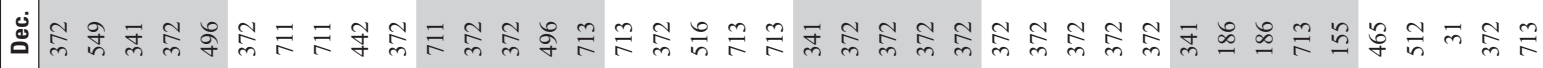

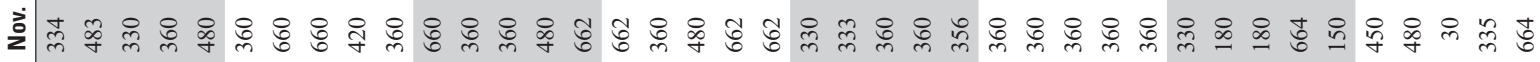

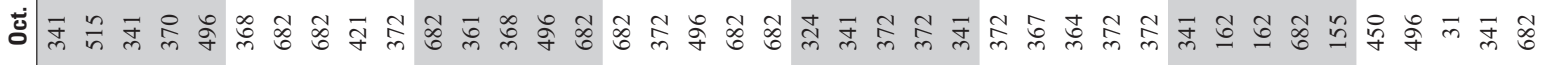

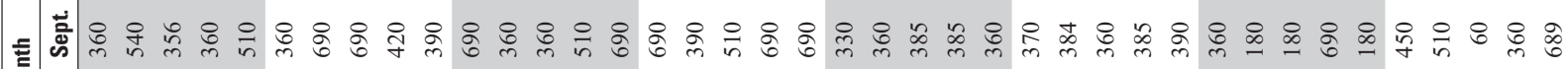

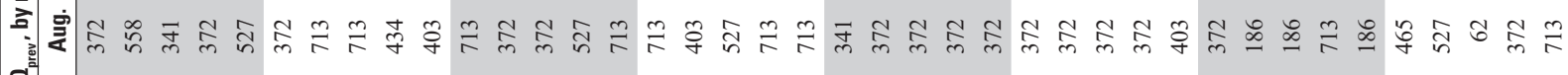

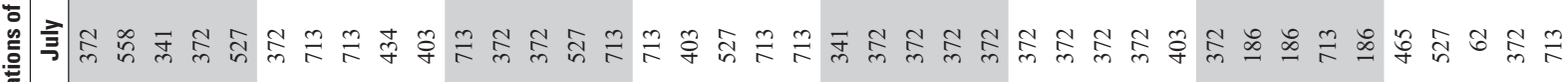

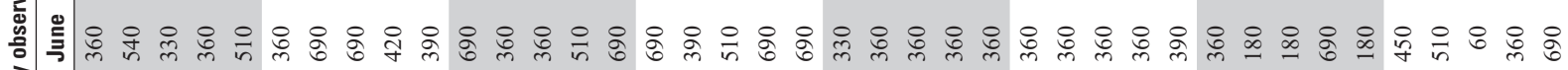

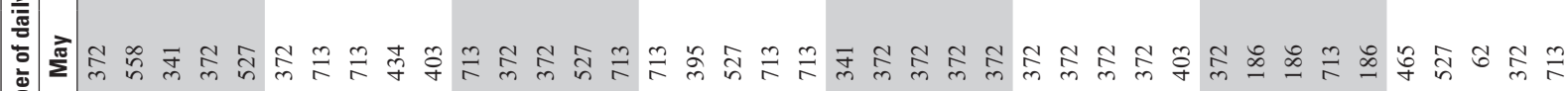

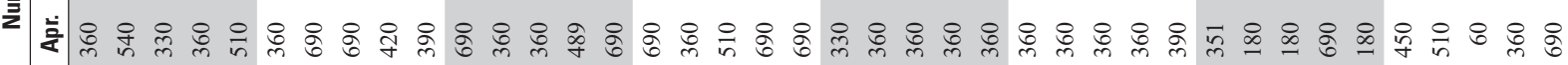

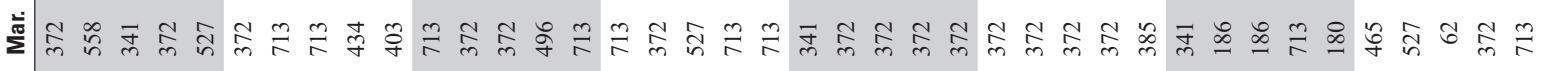

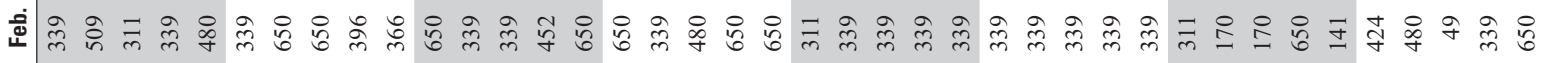

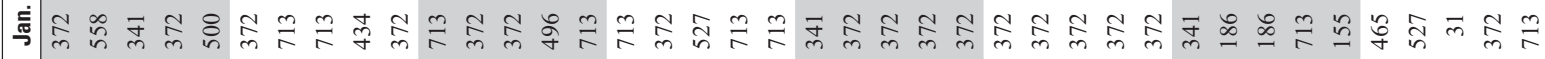

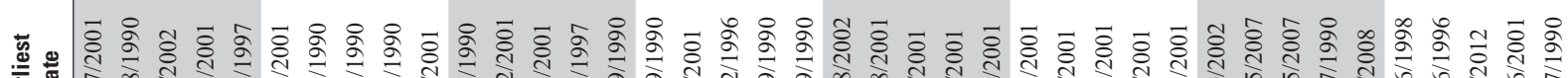

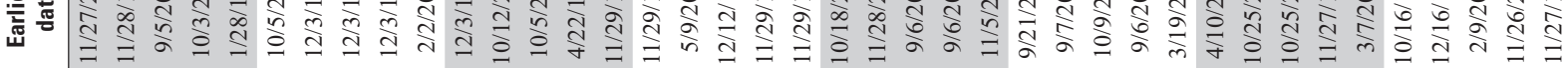

递

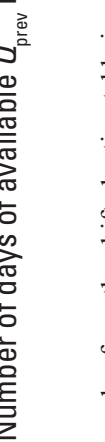

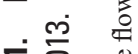

సัণ

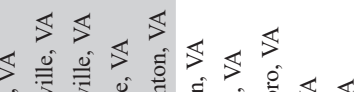

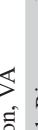

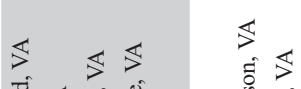

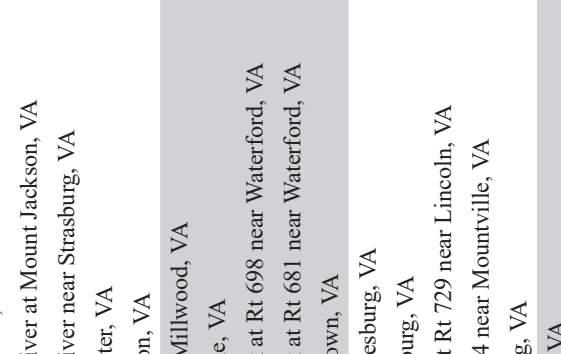

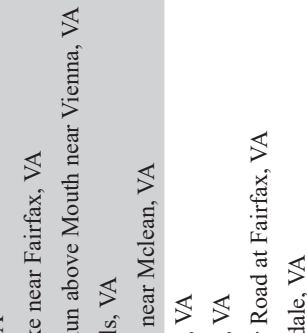

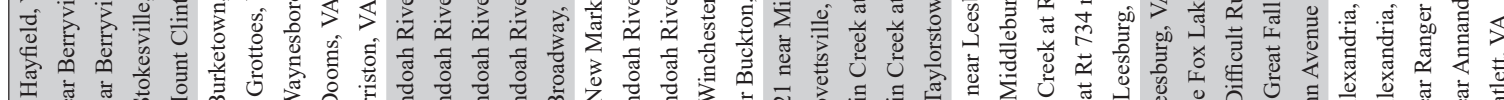

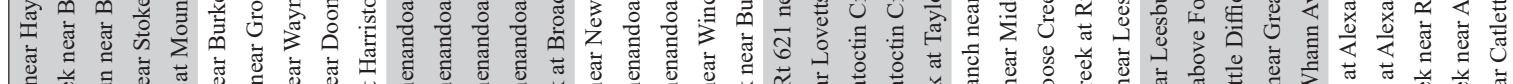

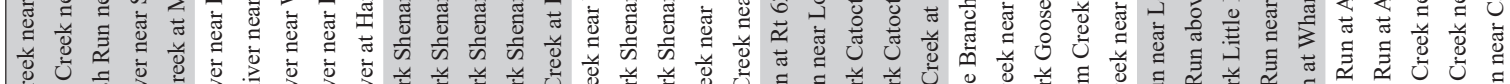

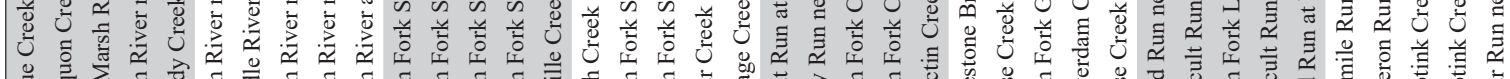

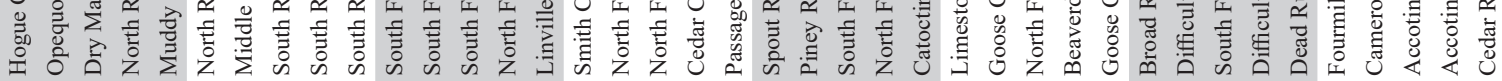

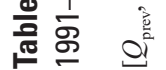




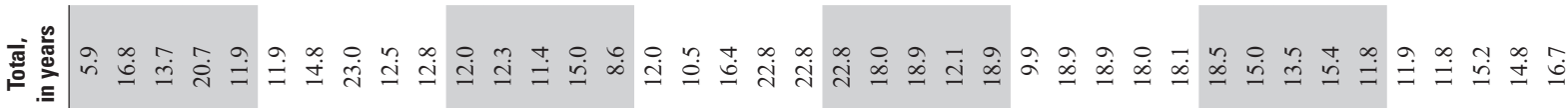

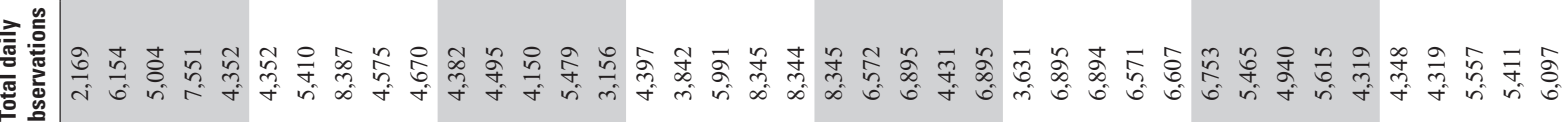

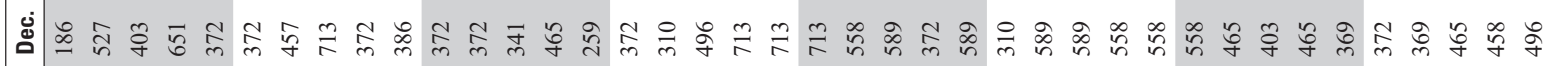

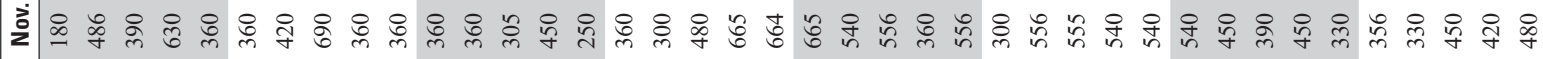

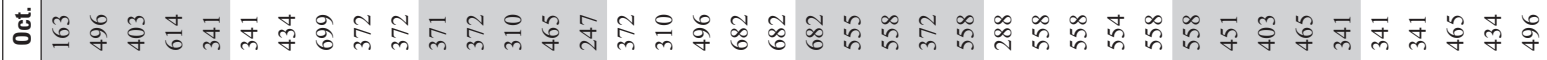

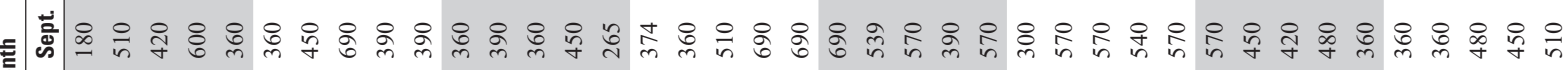

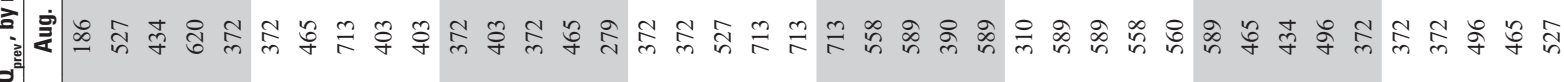

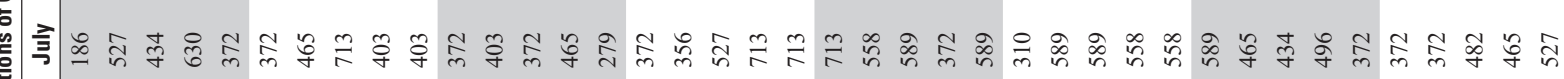

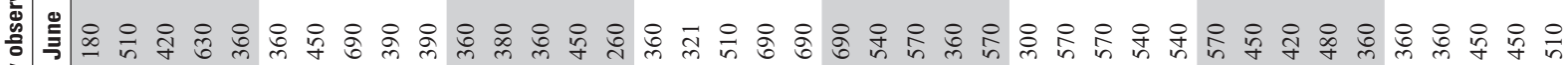

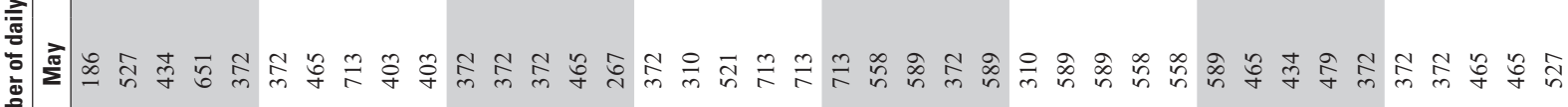

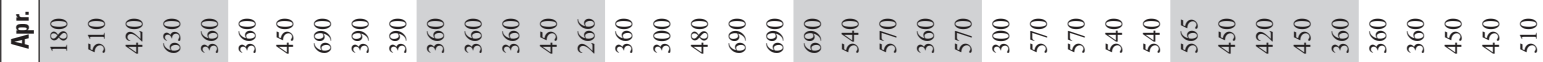

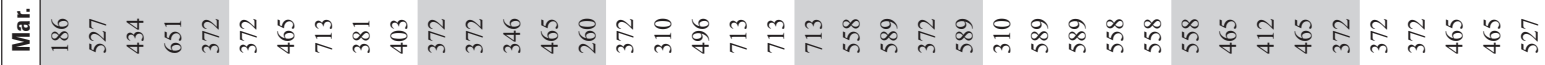

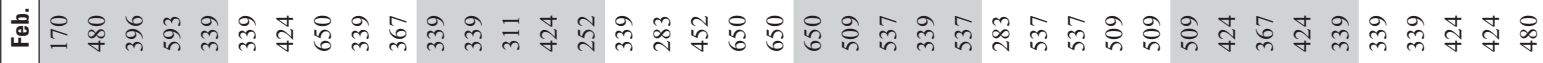

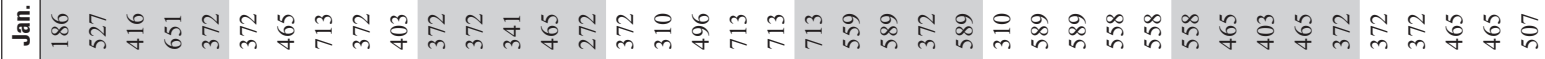

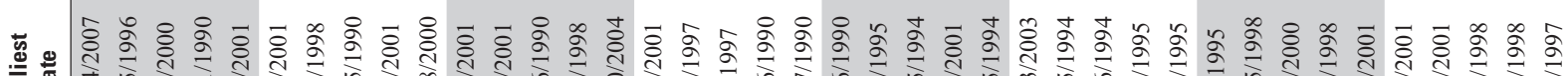

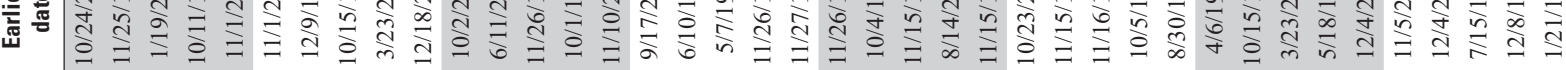

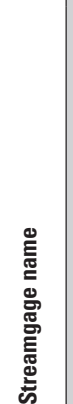

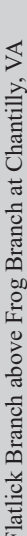

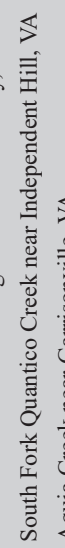
兽

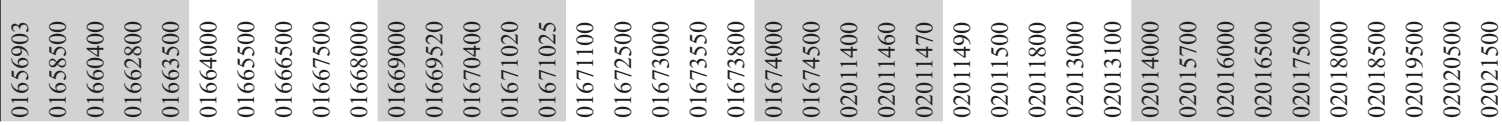




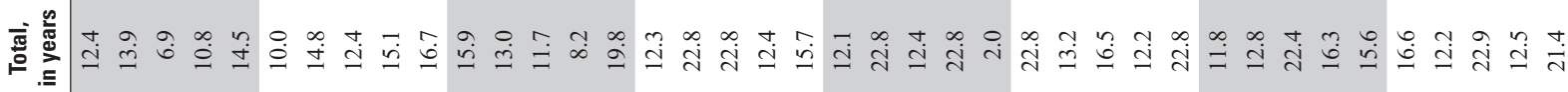
는

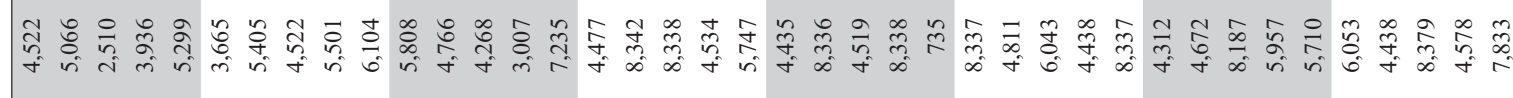

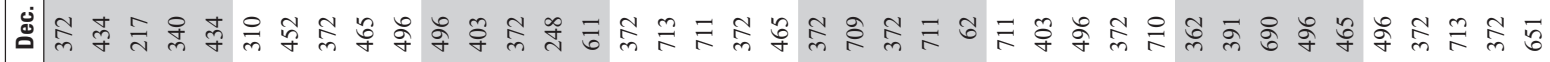

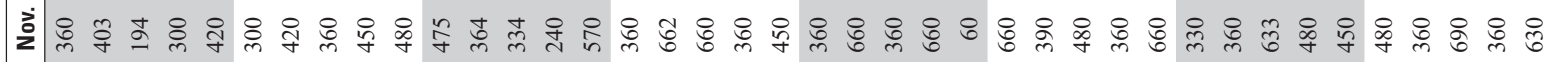

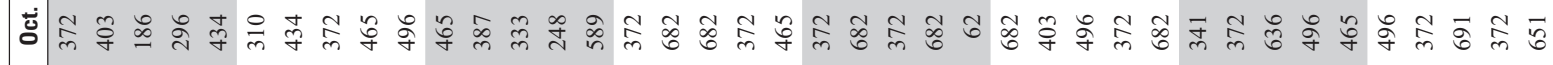

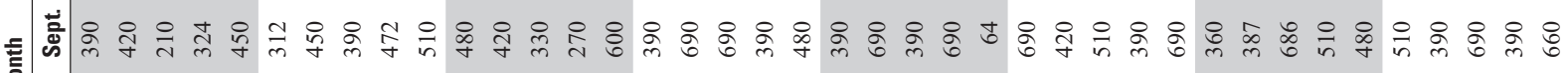

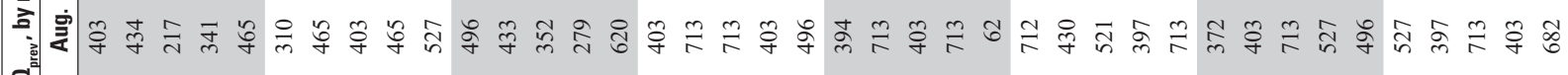

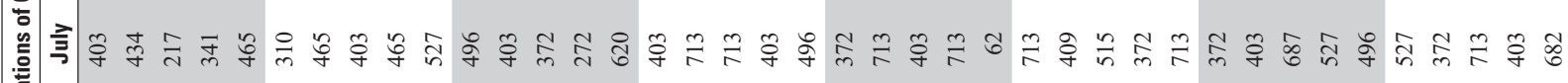

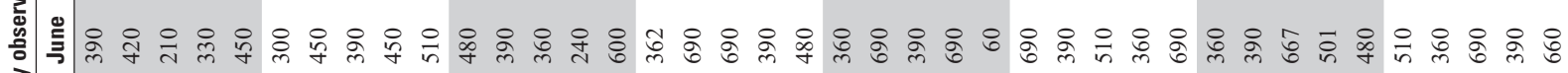

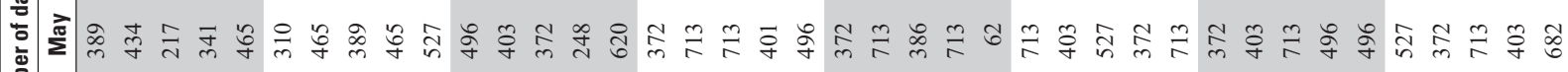

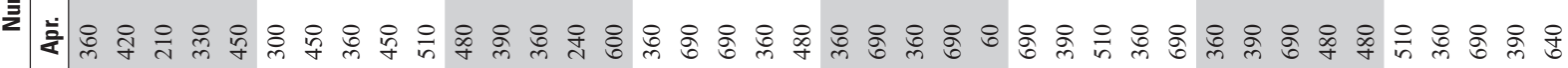

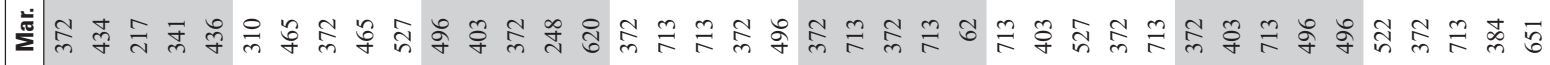

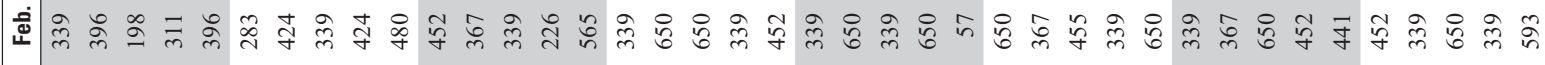

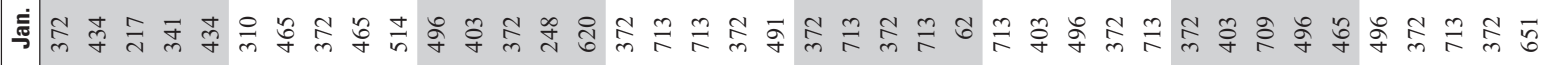

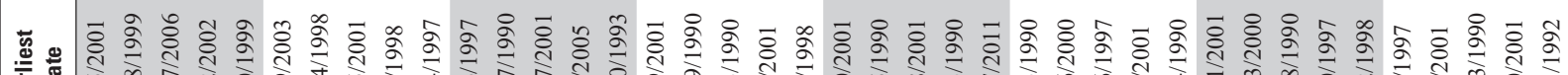

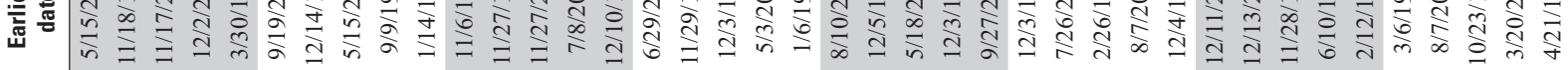




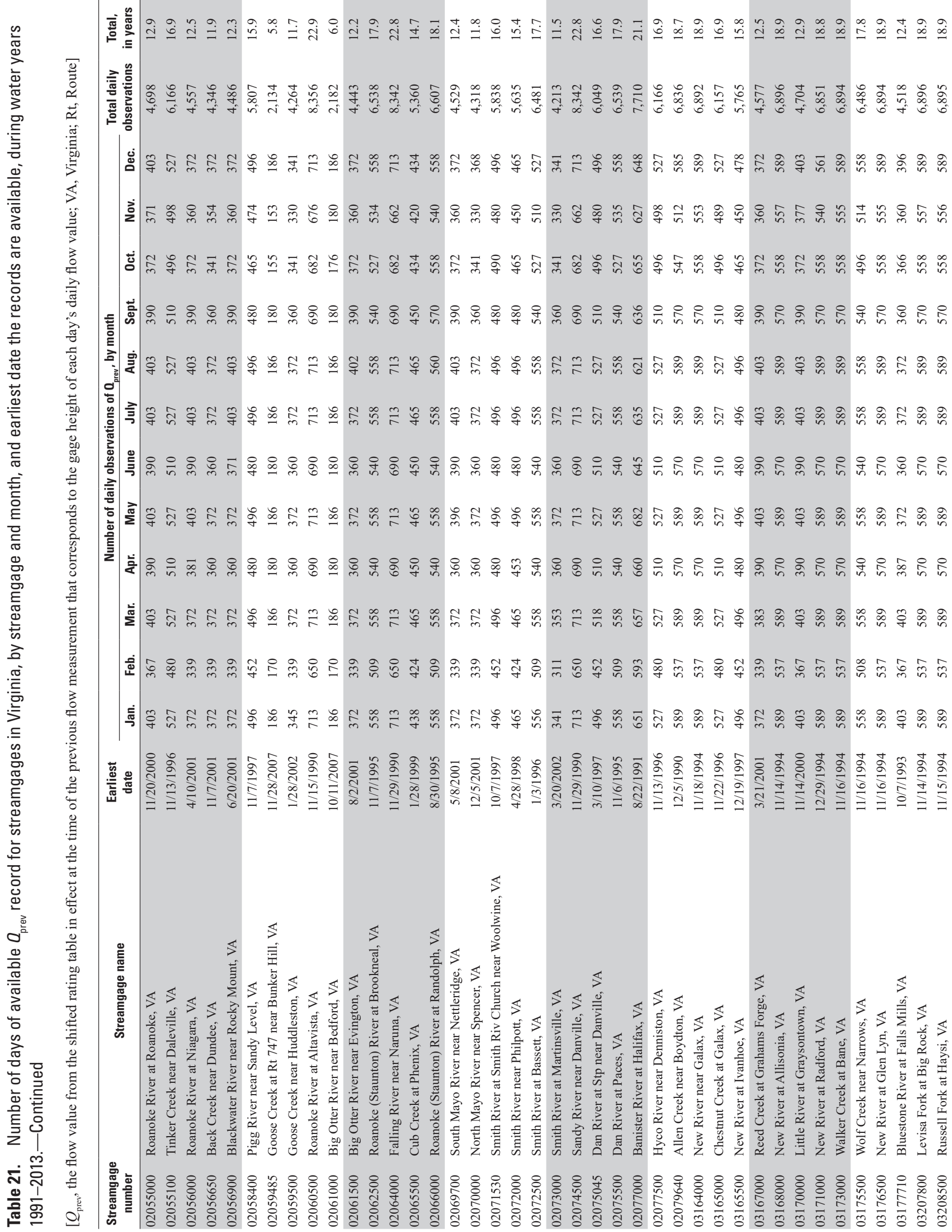




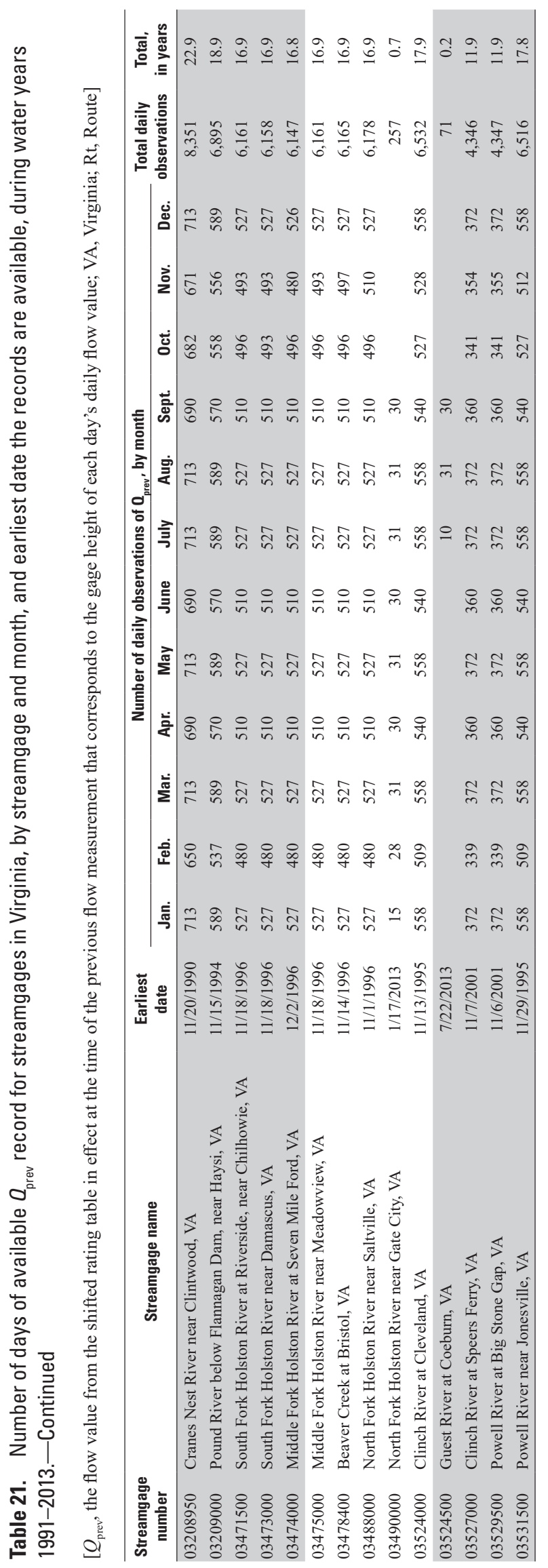


Table 22. Control and rating stability assessments made by senior hydrographers in the Virginia Water Science Center and Virginia Department of Environmental Quality for streamgages in Virginia active September 30, 2013.

[-, no response; E, excellent; G, good; F, fair; P, poor. Averages were computed by assigning numeric equivalents of 4 for excellent, 3 for good, 2 for fair, and 1 for poor. Italicized sites were not characterized by any hydrographer in response to questionnaires and were assigned scores by the authors from other descriptions. Individual hydrographers are identified by number, chronologically in the order that questionnaires were received; VA, Virginia; Rt, Route]

\begin{tabular}{|c|c|c|c|c|c|c|c|c|c|c|c|c|c|}
\hline \multirow{2}{*}{$\begin{array}{c}\text { Streamgage } \\
\text { number }\end{array}$} & \multirow{2}{*}{ Streamgage name } & \multicolumn{10}{|c|}{ Hydrographer } & \multirow{2}{*}{$\begin{array}{c}\text { Number } \\
\text { of } \\
\text { replies }\end{array}$} & \multirow{2}{*}{$\begin{array}{c}\text { Average } \\
\text { stability } \\
\text { score }\end{array}$} \\
\hline & & 1 & 2 & 3 & 4 & 5 & 6 & 7 & 8 & 9 & 10 & & \\
\hline 01613900 & Hogue Creek near Hayfield, VA & $\mathrm{F}$ & - & - & G & - & - & - & - & - & - & 2 & 2.5 \\
\hline 01616100 & Dry Marsh Run near Berryville, VA & - & - & $\mathrm{E}$ & $\mathrm{F}$ & - & - & - & $\mathrm{F}$ & - & - & 3 & 2.7 \\
\hline 01620500 & North River near Stokesville, VA & - & - & $\mathrm{F}$ & G & - & - & - & - & G & - & 3 & 2.7 \\
\hline 01625000 & Middle River near Grottoes, VA & $\mathrm{F}$ & - & - & G & - & - & - & - & - & - & 2 & 2.5 \\
\hline 01626000 & South River near Waynesboro, VA & $\mathrm{F}$ & - & - & G & - & - & - & - & - & - & 2 & 2.5 \\
\hline 01626850 & South River near Dooms, VA & $\mathrm{F}$ & - & - & G & - & - & - & - & - & - & 2 & 2.5 \\
\hline 01627500 & South River at Harriston, VA & $\mathrm{F}$ & - & - & G & - & - & - & - & - & - & 2 & 2.5 \\
\hline 01628500 & South Fork Shenandoah River near Lynnwood, VA & - & - & G & $\mathrm{E}$ & - & - & - & - & - & - & 2 & 3.5 \\
\hline 01632082 & Linville Creek at Broadway, VA & $\mathrm{F}$ & - & - & G & - & - & - & - & - & - & 2 & 2.5 \\
\hline 01632900 & Smith Creek near New Market, VA & - & - & - & $\mathrm{F}$ & - & - & - & $\mathrm{G}$ & - & - & 2 & 2.5 \\
\hline 01633000 & North Fork Shenandoah River at Mount Jackson, VA & $\mathrm{F}$ & - & - & G & - & - & - & - & - & - & 2 & 2.5 \\
\hline 01634000 & North Fork Shenandoah River near Strasburg, VA & - & - & $\mathrm{E}$ & G & - & - & - & G & - & - & 3 & 3.3 \\
\hline 01634500 & Cedar Creek near Winchester, VA & G & - & - & $\mathrm{G}$ & - & - & - & - & - & - & 2 & 3.0 \\
\hline 01635500 & Passage Creek near Buckton, VA & G & - & - & G & - & - & - & - & - & - & 2 & 3.0 \\
\hline 01636316 & Spout Run at Rt 621 near Millwood, VA & - & - & $\mathrm{E}$ & - & - & - & - & G & - & - & 2 & 3.5 \\
\hline 01636690 & Piney Run near Lovettsville, VA & - & - & G & - & - & - & - & $\mathrm{P}$ & - & - & 2 & 2.0 \\
\hline 01638350 & South Fork Catoctin Creek at Rt 698 near Waterford, VA & - & - & G & - & - & - & - & $\mathrm{P}$ & - & - & 2 & 2.0 \\
\hline 01638420 & North Fork Catoctin Creek at Rt 681 near Waterford, VA & - & - & G & - & - & - & - & G & - & - & 2 & 3.0 \\
\hline 01638480 & Catoctin Creek at Taylorstown, VA & $\mathrm{P}$ & - & - & $\mathrm{P}$ & - & - & - & - & - & - & 2 & 1.0 \\
\hline 01645704 & Difficult Run above Fox Lake near Fairfax, VA & - & $\mathrm{F}$ & $\mathrm{P}$ & - & - & G & - & - & - & - & 3 & 2.0 \\
\hline 01645762 & South Fork Little Difficult Run above Mouth near Vienna, VA & - & $\mathrm{F}$ & $\mathrm{P}$ & - & - & $\mathrm{P}$ & - & - & - & - & 3 & 1.3 \\
\hline 01646000 & Difficult Run near Great Falls, VA & - & G & G & G & - & $\mathrm{F}$ & - & - & - & - & 4 & 2.8 \\
\hline 01646305 & Dead Run at Whann Avenue near Mclean, VA & - & $\mathrm{F}$ & $\mathrm{P}$ & - & - & $\mathrm{P}$ & - & - & - & - & 3 & 1.3 \\
\hline 01652500 & Fourmile Run at Alexandria, VA & - & $\mathrm{F}$ & $\mathrm{F}$ & - & - & $\mathrm{P}$ & - & - & - & - & 3 & 1.7 \\
\hline 01653000 & Cameron Run at Alexandria, VA & - & $\mathrm{F}$ & $\mathrm{F}$ & - & - & $\mathrm{P}$ & - & - & - & - & 3 & 1.7 \\
\hline 0165389205 & Accotink Creek near Ranger Road at Fairfax, VA & - & - & G & - & - & - & - & - & - & - & 1 & 3.0 \\
\hline 01654000 & Accotink Creek near Annandale, VA & - & $\mathrm{P}$ & $\mathrm{P}$ & $\mathrm{P}$ & - & $\mathrm{P}$ & - & - & - & - & 4 & 1.0 \\
\hline 01656000 & Cedar Run near Catlett, VA & $\mathrm{F}$ & - & - & G & - & - & - & - & - & - & 2 & 2.5 \\
\hline 01656903 & Flatlick Branch above Frog Branch at Chantilly, VA & - & $\mathrm{F}$ & $\mathrm{F}$ & - & - & G & - & - & - & - & 3 & 2.3 \\
\hline 01658500 & South Fork Quantico Creek near Independent Hill, VA & - & - & $\mathrm{F}$ & - & - & $\mathrm{F}$ & - & - & - & - & 2 & 2.0 \\
\hline 01660400 & Aquia Creek near Garrisonville, VA & - & - & $\mathrm{F}$ & - & - & $\mathrm{G}$ & - & - & G & - & 3 & 2.7 \\
\hline 01662800 & Battle Run near Laurel Mills, VA & $\mathrm{F}$ & - & - & $\mathrm{F}$ & - & - & - & - & - & - & 2 & 2.0 \\
\hline 01663500 & Hazel River at Rixeyville, VA & - & - & G & - & - & G & - & - & G & - & 3 & 3.0 \\
\hline
\end{tabular}


Table 22. Control and rating stability assessments made by senior hydrographers in the Virginia Water Science Center and Virginia Department of Environmental Quality for streamgages in Virginia active September 30, 2013. - Continued

[-, no response; E, excellent; G, good; F, fair; P, poor. Averages were computed by assigning numeric equivalents of 4 for excellent, 3 for good, 2 for fair, and 1 for poor. Italicized sites were not characterized by any hydrographer in response to questionnaires and were assigned scores by the authors from other descriptions. Individual hydrographers are identified by number, chronologically in the order that questionnaires were received; VA, Virginia; Rt, Route]

\begin{tabular}{|c|c|c|c|c|c|c|c|c|c|c|c|c|c|}
\hline \multirow{2}{*}{$\begin{array}{c}\text { Streamgage } \\
\text { number }\end{array}$} & \multirow{2}{*}{ Streamgage name } & \multicolumn{10}{|c|}{ Hydrographer } & \multirow{2}{*}{$\begin{array}{c}\text { Number } \\
\text { of } \\
\text { replies }\end{array}$} & \multirow{2}{*}{$\begin{array}{c}\text { Average } \\
\text { stability } \\
\text { score }\end{array}$} \\
\hline & & 1 & 2 & 3 & 4 & 5 & 6 & 7 & 8 & 9 & 10 & & \\
\hline 01664000 & Rappahannock River at Remington, VA & - & - & G & - & - & G & - & - & G & - & 3 & 3.0 \\
\hline 01666500 & Robinson River near Locust Dale, VA & $\mathrm{F}$ & - & - & $\mathrm{F}$ & - & - & - & - & - & - & 2 & 2.0 \\
\hline 01667500 & Rapidan River near Culpeper, VA & $\mathrm{F}$ & - & - & $\mathrm{E}$ & - & - & - & - & - & - & 2 & 3.0 \\
\hline 01669520 & Dragon Swamp at Mascot, VA & $\mathrm{P}$ & - & - & - & - & - & - & - & - & - & 1 & 1.0 \\
\hline 01670400 & North Anna River near Partlow, VA & - & - & G & - & - & G & G & - & - & - & 3 & 3.0 \\
\hline 01671020 & North Anna River at Hart Corner near Doswell, VA & - & - & - & $\mathrm{F}$ & - & - & - & - & - & - & 1 & 2.0 \\
\hline 01671025 & North Anna River above Little River near Doswell, VA & $\mathrm{P}$ & - & $\mathrm{F}$ & - & - & $\mathrm{F}$ & G & - & $\mathrm{F}$ & - & 5 & 2.0 \\
\hline 01671100 & Little River near Doswell, VA & $\mathrm{F}$ & - & - & $\mathrm{F}$ & - & - & - & - & - & - & 2 & 2.0 \\
\hline 01673800 & Po River near Spotsylvania, VA & $\mathrm{P}$ & - & - & G & - & - & - & - & - & - & 2 & 2.0 \\
\hline 01674000 & Mattaponi River near Bowling Green, VA & - & - & G & G & - & G & - & - & G & - & 4 & 3.0 \\
\hline 01674500 & Mattaponi River near Beulahville, VA & - & - & G & - & - & G & - & - & G & - & 3 & 3.0 \\
\hline 02011400 & Jackson River near Bacova, VA & - & - & G & $\mathrm{E}$ & - & - & - & - & - & - & 2 & 3.5 \\
\hline 02011460 & Back Creek near Sunrise, VA & - & - & - & $\mathrm{E}$ & - & - & - & - & - & - & 1 & 4.0 \\
\hline 02011470 & Back Creek at Sunrise, VA & - & - & - & $\mathrm{E}$ & - & - & - & - & - & - & 1 & 4.0 \\
\hline 02011490 & Little Back Creek near Sunrise, VA & - & - & - & $\mathrm{E}$ & - & - & - & - & - & - & 1 & 4.0 \\
\hline 02011500 & Back Creek near Mountain Grove, VA & - & - & - & $\mathrm{E}$ & - & - & - & - & - & - & 1 & 4.0 \\
\hline 02011800 & Jackson River below Gathright Dam near Hot Spgs, VA & - & - & - & $\mathrm{E}$ & - & - & - & - & - & - & 1 & 4.0 \\
\hline 02013000 & Dunlap Creek near Covington, VA & - & - & - & G & - & - & - & - & - & - & 1 & 3.0 \\
\hline 02013100 & Jackson River below Dunlap Creek at Covington, VA & - & - & - & G & - & - & - & - & - & - & 1 & 3.0 \\
\hline 02018500 & Catawba Creek near Catawba, VA & $\mathrm{F}$ & - & - & G & - & - & - & - & - & - & 2 & 2.5 \\
\hline 02019500 & James River at Buchanan, VA & - & G & - & $\mathrm{E}$ & - & - & - & - & - & - & 2 & 3.5 \\
\hline 02020500 & Calfpasture River above Mill Creek at Goshen, VA & $\mathrm{F}$ & - & - & G & - & - & - & - & - & - & 2 & 2.5 \\
\hline 02021500 & Maury River at Rockbridge Baths, VA & - & G & $\mathrm{G}$ & E & - & - & - & - & $\mathrm{G}$ & - & 4 & 3.3 \\
\hline 02022500 & Kerrs Creek near Lexington, VA & G & - & - & G & - & - & - & - & - & - & 2 & 3.0 \\
\hline 02024000 & Maury River near Buena Vista, VA & - & G & $\mathrm{F}$ & G & - & - & - & - & G & - & 4 & 2.8 \\
\hline 02024752 & James River at Blue Ridge Pkwy near Big Island, VA & $\mathrm{G}$ & - & $\mathrm{P}$ & G & - & - & - & - & - & - & 3 & 2.3 \\
\hline 02024915 & Pedlar River at Forest Road near Buena Vista, VA & $\mathrm{F}$ & - & - & G & - & - & - & - & - & - & 2 & 2.5 \\
\hline 02025500 & James River at Holcomb Rock, VA & - & $\mathrm{F}$ & $\mathrm{F}$ & $\mathrm{E}$ & - & - & - & - & G & - & 4 & 2.8 \\
\hline 02026000 & James River at Bent Creek, VA & - & $\mathrm{F}$ & $\mathrm{G}$ & $\mathrm{E}$ & - & - & - & - & $\mathrm{G}$ & - & 4 & 3.0 \\
\hline 02027000 & Tye River near Lovingston, VA & $\mathrm{F}$ & - & - & G & - & - & - & - & - & - & 2 & 2.5 \\
\hline 02027500 & Piney River at Piney River, VA & $\mathrm{F}$ & - & - & G & - & - & - & - & - & - & 2 & 2.5 \\
\hline 02028500 & Rockfish River near Greenfield, VA & $\mathrm{F}$ & - & - & G & - & - & - & - & - & - & 2 & 2.5 \\
\hline 02029000 & James River at Scottsville, VA & - & - & $\mathrm{G}$ & $\mathrm{E}$ & - & $\mathrm{E}$ & $\mathrm{G}$ & - & $\mathrm{G}$ & - & 5 & 3.4 \\
\hline
\end{tabular}


Table 22. Control and rating stability assessments made by senior hydrographers in the Virginia Water Science Center and Virginia Department of Environmental Quality for streamgages in Virginia active September 30, 2013.-Continued

[-, no response; E, excellent; G, good; F, fair; P, poor. Averages were computed by assigning numeric equivalents of 4 for excellent, 3 for good, 2 for fair, and 1 for poor. Italicized sites were not characterized by any hydrographer in response to questionnaires and were assigned scores by the authors from other descriptions. Individual hydrographers are identified by number, chronologically in the order that questionnaires were received; VA, Virginia; Rt, Route]

\begin{tabular}{|c|c|c|c|c|c|c|c|c|c|c|c|c|c|}
\hline \multirow{2}{*}{$\begin{array}{c}\text { Streamgage } \\
\text { number }\end{array}$} & \multirow{2}{*}{ Streamgage name } & \multicolumn{10}{|c|}{ Hydrographer } & \multirow{2}{*}{$\begin{array}{c}\text { Number } \\
\text { of } \\
\text { replies }\end{array}$} & \multirow{2}{*}{$\begin{array}{c}\text { Average } \\
\text { stability } \\
\text { score }\end{array}$} \\
\hline & & 1 & 2 & 3 & 4 & 5 & 6 & 7 & 8 & 9 & 10 & & \\
\hline 02030000 & Hardware River below Briery Run near Scottsville, VA & $\mathrm{P}$ & - & - & G & - & - & - & - & - & - & 2 & 2.0 \\
\hline 02030500 & Slate River near Arvonia, VA & $\mathrm{F}$ & - & - & G & - & - & - & - & - & - & 2 & 2.5 \\
\hline 02031000 & Mechums River near White Hall, VA & $\mathrm{F}$ & - & - & G & - & - & - & - & - & - & 2 & 2.5 \\
\hline 02032250 & Moormans River near Free Union, VA & $\mathrm{F}$ & - & - & G & - & - & - & - & - & - & 2 & 2.5 \\
\hline 02032640 & North Fork Rivanna River near Earlysville, VA & $\mathrm{F}$ & - & - & G & - & - & - & - & - & - & 2 & 2.5 \\
\hline 02034000 & Rivanna River at Palmyra, VA & $\mathrm{F}$ & - & - & G & - & - & - & - & - & - & 2 & 2.5 \\
\hline 02035000 & James River at Cartersville, VA & - & - & G & - & - & E & G & - & E & - & 4 & 3.5 \\
\hline 02036500 & Fine Creek at Fine Creek Mills, VA & $\mathrm{F}$ & - & - & E & - & - & - & - & - & - & 2 & 3.0 \\
\hline 02037000 & James River And Kanawha Canal near Richmond, VA & $\mathrm{P}$ & - & - & G & - & - & - & - & - & - & 2 & 2.0 \\
\hline 02037500 & James River near Richmond, VA & G & - & - & E & - & - & - & - & - & - & 2 & 3.5 \\
\hline 02038850 & Holiday Creek near Andersonville, VA & - & - & $\mathrm{F}$ & - & - & - & G & - & G & - & 3 & 2.7 \\
\hline 02039000 & Buffalo Creek near Hampden Sydney, VA & $\mathrm{F}$ & - & - & $\mathrm{F}$ & - & - & - & - & - & - & 2 & 2.0 \\
\hline 02039500 & Appomattox River at Farmville, VA & - & - & G & G & - & G & G & - & G & - & 5 & 3.0 \\
\hline 02040000 & Appomattox River at Mattoax, VA & $\mathrm{P}$ & - & - & $\mathrm{F}$ & - & - & - & - & - & - & 2 & 1.5 \\
\hline 02040892 & Appomattox River at Route 602 near Mannboro, VA & - & - & G & - & - & G & G & - & G & - & 4 & 3.0 \\
\hline 02041000 & Deep Creek near Mannboro, VA & $P$ & - & - & $\mathrm{F}$ & - & - & - & - & - & - & 2 & 1.5 \\
\hline 02041650 & Appomattox River at Matoaca, VA & $\mathrm{F}$ & - & - & G & - & - & - & - & - & - & 2 & 2.5 \\
\hline 02042500 & Chickahominy River near Providence Forge, VA & - & - & E & - & - & G & G & - & G & - & 4 & 3.3 \\
\hline 02044500 & Nottoway River near Rawlings, VA & $\mathrm{F}$ & - & - & G & - & - & - & - & - & - & 2 & 2.5 \\
\hline 02045500 & Nottoway River near Stony Creek, VA & $\mathrm{F}$ & - & - & G & - & - & - & - & - & - & 2 & 2.5 \\
\hline 02046000 & Stony Creek near Dinwiddie, VA & $\mathrm{F}$ & - & - & $\mathrm{G}$ & - & - & - & - & - & - & 2 & 2.5 \\
\hline 02047000 & Nottoway River near Sebrell, VA & - & - & $\mathrm{F}$ & - & - & G & - & - & G & - & 3 & 2.7 \\
\hline 02047500 & Blackwater River near Dendron, VA & $\mathrm{P}$ & - & - & - & - & - & - & - & - & - & 1 & 1.0 \\
\hline 02049500 & Blackwater River near Franklin, VA & - & - & $\mathrm{P}$ & - & - & $\mathrm{P}$ & - & - & $\mathrm{F}$ & - & 3 & 1.3 \\
\hline 02051000 & North Meherrin River near Lunenburg, VA & $\mathrm{F}$ & - & - & G & - & - & - & - & - & - & 2 & 2.5 \\
\hline 02051500 & Meherrin River near Lawrenceville, VA & - & - & G & - & - & G & - & - & $\mathrm{F}$ & - & 3 & 2.7 \\
\hline 02052000 & Meherrin River at Emporia, VA & $\mathrm{P}$ & - & - & $\mathrm{F}$ & - & - & - & - & - & - & 2 & 1.5 \\
\hline 02053800 & South Fork Roanoke River near Shawsville, VA & $\mathrm{F}$ & - & - & G & - & - & - & - & - & - & 2 & 2.5 \\
\hline 02054500 & Roanoke River at Lafayette, VA & $\mathrm{F}$ & - & - & G & - & - & - & - & - & - & 2 & 2.5 \\
\hline 02054530 & Roanoke River at Glenvar, VA & $\mathrm{F}$ & - & - & G & - & - & - & - & - & - & 2 & 2.5 \\
\hline 02055000 & Roanoke River at Roanoke, VA & - & G & - & G & - & - & - & - & - & - & 2 & 3.0 \\
\hline 02055100 & Tinker Creek near Daleville, VA & - & - & - & G & - & - & - & - & - & - & 1 & 3.0 \\
\hline 02056000 & Roanoke River at Niagara, VA & - & G & - & G & - & - & - & - & - & - & 2 & 3.0 \\
\hline 02056650 & Back Creek near Dundee, VA & $\mathrm{F}$ & - & - & G & - & - & - & - & - & - & 2 & 2.5 \\
\hline 02056900 & Blackwater River near Rocky Mount, VA & G & - & - & G & - & - & - & - & - & - & 2 & 3.0 \\
\hline 02058400 & Pigg River near Sandy Level, VA & - & - & $\mathrm{P}$ & - & - & $\mathrm{F}$ & - & - & G & - & 3 & 2.0 \\
\hline 02059485 & Goose Creek at Rt 747 near Bunker Hill, VA & - & - & - & - & - & - & - & - & - & - & 0 & 3.0 \\
\hline 02059500 & Goose Creek near Huddleston, VA & G & - & - & G & - & - & - & - & - & - & 2 & 3.0 \\
\hline 02060500 & Roanoke River at Altavista, VA & - & - & G & - & - & G & - & - & G & - & 3 & 3.0 \\
\hline 02061000 & Big Otter River near Bedford, VA & - & - & - & - & - & - & - & - & - & - & 0 & 3.0 \\
\hline 02061500 & Big Otter River near Evington, VA & $\mathrm{F}$ & - & - & G & - & - & - & - & - & - & 2 & 2.5 \\
\hline 02062500 & Roanoke (Staunton) River at Brookneal, VA & - & - & G & - & - & G & - & - & G & - & 3 & 3.0 \\
\hline 02064000 & Falling River near Naruna, VA & G & - & - & G & - & - & - & - & - & - & 2 & 3.0 \\
\hline 02065500 & Cub Creek at Phenix, VA & $\mathrm{F}$ & - & - & $\mathrm{F}$ & - & - & - & - & - & - & 2 & 2.0 \\
\hline 02066000 & Roanoke (Staunton) River at Randolph, VA & - & - & $\mathrm{F}$ & - & _- & G & _- & _- & G & - & 3 & 2.7 \\
\hline
\end{tabular}


Table 22. Control and rating stability assessments made by senior hydrographers in the Virginia Water Science Center and Virginia Department of Environmental Quality for streamgages in Virginia active September 30, 2013.—Continued

[-, no response; E, excellent; G, good; F, fair; P, poor. Averages were computed by assigning numeric equivalents of 4 for excellent, 3 for good, 2 for fair, and 1 for poor. Italicized sites were not characterized by any hydrographer in response to questionnaires and were assigned scores by the authors from other descriptions. Individual hydrographers are identified by number, chronologically in the order that questionnaires were received; VA, Virginia; Rt, Route]

\begin{tabular}{|c|c|c|c|c|c|c|c|c|c|c|c|c|c|}
\hline \multirow{2}{*}{$\begin{array}{c}\text { Streamgage } \\
\text { number }\end{array}$} & \multirow[b]{2}{*}{ Streamgage name } & \multicolumn{10}{|c|}{ Hydrographer } & \multirow{2}{*}{$\begin{array}{c}\text { Number } \\
\text { of } \\
\text { replies }\end{array}$} & \multirow{2}{*}{$\begin{array}{c}\text { Average } \\
\text { stability } \\
\text { score }\end{array}$} \\
\hline & & 1 & 2 & 3 & 4 & 5 & 6 & 7 & 8 & 9 & 10 & & \\
\hline 02069700 & South Mayo River near Nettleridge, VA & $\mathrm{F}$ & - & - & $\mathrm{F}$ & - & - & - & - & - & - & 2 & 2.0 \\
\hline 02071530 & Smith River at Smith Riv Church near Woolwine, VA & $\mathrm{F}$ & - & - & $\mathrm{F}$ & - & - & - & - & - & - & 2 & 2.0 \\
\hline 02072000 & Smith River near Philpott, VA & - & - & G & - & - & $\mathrm{E}$ & - & - & G & - & 3 & 3.3 \\
\hline 02074500 & Sandy River near Danville, VA & G & - & - & G & - & - & - & - & - & - & 2 & 3.0 \\
\hline 02075045 & Dan River at Stp near Danville, VA & - & - & G & - & - & G & - & - & G & - & 3 & 3.0 \\
\hline 02075500 & Dan River at Paces, VA & - & - & $\mathrm{F}$ & - & - & $\mathrm{F}$ & - & - & $\mathrm{F}$ & - & 3 & 2.0 \\
\hline 02077000 & Banister River at Halifax, VA & - & - & G & - & - & G & - & - & G & - & 3 & 3.0 \\
\hline 02077500 & Hyco River near Denniston, VA & - & - & $\mathrm{P}$ & - & - & - & - & - & G & - & 2 & 2.0 \\
\hline 03165500 & New River at Ivanhoe, VA & - & - & - & - & $\mathrm{G}$ & - & - & - & - & $\mathrm{F}$ & 2 & 2.5 \\
\hline 03167000 & Reed Creek at Grahams Forge, VA & - & - & - & - & G & - & - & - & - & G & 2 & 3.0 \\
\hline 03168000 & New River at Allisonia, VA & - & - & - & - & $\mathrm{E}$ & - & - & - & - & $\mathrm{E}$ & 2 & 4.0 \\
\hline 03170000 & Little River at Graysontown, VA & - & - & - & - & G & - & - & - & - & G & 2 & 3.0 \\
\hline 03171000 & New River at Radford, VA & - & - & - & - & $\mathrm{G}$ & - & - & - & - & G & 2 & 3.0 \\
\hline 03173000 & Walker Creek at Bane, VA & - & - & - & - & G & - & - & - & - & G & 2 & 3.0 \\
\hline 03175500 & Wolf Creek near Narrows, VA & - & - & - & - & G & - & - & - & - & G & 2 & 3.0 \\
\hline 03176500 & New River at Glen Lyn, VA & - & - & - & - & G & - & - & - & - & G & 2 & 3.0 \\
\hline 03177710 & Bluestone River at Falls Mills, VA & - & - & - & - & $\mathrm{F}$ & - & - & - & - & G & 2 & 2.5 \\
\hline 03207800 & Levisa Fork at Big Rock, VA & - & - & - & - & $\mathrm{G}$ & - & - & - & - & G & 2 & 3.0 \\
\hline 03208500 & Russell Fork at Haysi, VA & - & - & - & - & G & - & - & - & - & G & 2 & 3.0 \\
\hline 03478400 & Beaver Creek at Bristol, VA & - & - & - & - & $\mathrm{G}$ & - & - & - & - & G & 2 & 3.0 \\
\hline 03488000 & North Fork Holston River near Saltville, VA & - & - & - & - & G & - & - & - & - & G & 2 & 3.0 \\
\hline 03490000 & North Fork Holston River near Gate City, VA & - & - & - & - & $\mathrm{F}$ & - & - & - & - & $\mathrm{F}$ & 2 & 2.0 \\
\hline 03524000 & Clinch River at Cleveland, VA & - & - & - & - & G & - & - & - & - & G & 2 & 3.0 \\
\hline 03524500 & Guest River at Coeburn, VA & - & - & - & - & $\mathrm{F}$ & - & - & - & - & G & 2 & 2.5 \\
\hline 03527000 & Clinch River at Speers Ferry, VA & - & - & - & - & $\mathrm{F}$ & - & - & - & - & G & 2 & 2.5 \\
\hline 03529500 & Powell River at Big Stone Gap, VA & - & - & - & - & $\mathrm{F}$ & - & - & - & - & $\mathrm{F}$ & 2 & 2.0 \\
\hline 03531500 & Powell River near Jonesville, VA & - & - & - & - & $\mathrm{G}$ & - & - & - & - & G & 2 & 3.0 \\
\hline Totals: & 174 & 69 & 19 & 61 & 100 & 27 & 36 & 10 & 14 & 35 & 27 & 398 & 2.6 \\
\hline
\end{tabular}





\section{Appendix 1. Plots for real-time streamgages in Virginia}

\section{A. All available measurements}

Three columns of plots for all real-time streamgages in Virginia active on September 30, 2013, with 20 or more flow measurements with positive flow values, organized by major river basin, with all available measurements for each site color coded by rating family showing (1) stage, flow, and a generalized additive model (GAM) curve. Appendix $1 A$ depicts all available measurements for each plot, unlike appendix $1 B$, which groups measurements at each site by rating families. Rating families represent a series of measurements made during a period when a streamgage control was at relative equilibrium. For streamgages where more than one rating family was identified, they were numbered sequentially in chronological order as RF1, RF2, ... RFn; non-sequential rating family numbers result from situations in which a rating family was omitted because its period of equilibrium did not last long enough for a sufficient number of measurements to be made to allow a meaningful GAM to be developed. The coefficient of determination for the GAM curve, $\mathrm{R}^{2}$, is a measure of the amount of variation in the stagestreamflow relation explained by the GAM; (2) residuals from the GAM curve by date (times series scale of graphs vary), with a LOESS smoother; and (3) residuals from the GAM curve by Julian date, with a LOESS smoother. Shaded areas represent the 99-percent confidence interval of the relevant curve.

\section{B. Measurements grouped by rating families}

Three columns of plots for all real-time streamgages in Virginia active on September 30, 2013, with 20 or more flow measurements with positive flow values organized by major river basin, with all available measurements for each site, showing (1) stage, flow, and a generalized additive model (GAM) curve. Unlike appendix $1 A$, which depicts all available measurements for each plot, appendix $1 B$ groups measurements at each site by rating families. Rating families represent a series of measurements made during a period when a streamgage control was at relative equilibrium. For streamgages where more than one rating family was identified, they were numbered sequentially in chronological order as RF1, RF2, . RFn; non-sequential rating family numbers result from situations in which a rating family was omitted because its period of equilibrium did not last long enough for a sufficient number of measurements to be made to allow a meaningful GAM to be developed. The coefficient of determination for the GAM curve, $\mathrm{R}^{2}$, is a measure of the amount of variation in the stage-streamflow relation explained by the GAM; (2) residuals from the GAM curve by date, and (3) residuals from the GAM curve by Julian date. Shaded areas represent the 99-percent confidence interval of the relevant curve.

Appendix 1 is available online at https://doi.org/10.3133/sir20175137 


\section{Appendix 2. Computation of Alternative Flow (AltFlow) Data}

Two primary datasets were used to develop the AltFlow tables, (1) daily flow values for 1990-2013 and (2) the compiled tables of expanded shifted ratings (Messinger and Burgholzer, 2017). Two ancillary datasets also were used. A table containing all flow measurements was retrieved from NWIS-Web (National Water Information System-Web) and used to identify dates on which those flow measurements were made. Daily flows $\left(Q_{\text {meas }}\right)$ were retrieved from NWIS-Web. A table of all shifts was retrieved from the NWIS commandline interface and manually processed to identify the earliest dates for each streamgage for which shifts were stored in the database (table 2).

Columns in the AltFlow table that originated in the retrieval of daily flow values included station number (site_no), date, flow in cubic feet per second, and qualifier (Messinger and Burgholzer, 2017). Because dates in other files were formatted in multiple ways, date in the original MM/DD/YYYY format (month as a two-digit number, date as a two-digit number, and year as a four-digit number, with the three sets of numbers separated by slashes) was retained. Another column was created and populated with date in the YYYYMMDD format (year as a four-digit number, month as a two-digit number, and date as a two-digit number, with no separators of any type between the three sets of numbers).

For each streamgage, the earliest date when AltFlows could be computed was determined ("Valid Start Date"). This date was the earliest date for which both base ratings and shifts were available. Both shifts and ratings were assumed to be continuously available following this date. These dates were identified in a table developed from retrievals of ratings and shifts, and imported to this table using the Microsoft Excel VLOOKUP command with the site_no used for the lookup value. Once analysis and verification related to that table was final, the formulas were converted to values in order to reduce file size. All dates with values of $Q_{\text {meas }}$ were compared to Valid Start Date for the relevant streamgage and flagged as to whether or not valid values for $Q_{\text {prev }}$ and $Q_{\text {same }}$ could potentially be computed for that date.

The column "Lookup" contains a unique identifier for streamgage-date combinations. It is of the format Q.site no.yyyymmdd, where site no is the 8- or 10-digit station number and yyyymmdd is the date. The column was populated by concatenating the letter " $Q$ " and the two other values; the letter "Q" was used as the first character in order to prevent Excel, R, and other software from truncating the leading zero from the station number. Lookup was used in conjunction with the VLOOKUP and INDEX/MATCH commands to populate several columns in this table by importing values from other tables.

The column "Expanded rating code" contains the value from the Lookup column for the dates when a retrieval of the expanded shifted rating table was desired. These represent dates when a flow measurement was made. This column was developed in order to simplify filtering the table for verification checks and to reduce the complexity of IF statements used elsewhere in the table. It was populated by using the VLOOKUP command to retrieve the same code from a table of flow measurements; for dates not represented in the other table, an error code was returned. This table of flow measurements was obtained from NWIS-Web, and the only manual processing step that needed to be done in order to use it to develop the column "Expanded rating code" was to concatenate the letter "Q" with the values for station numbers and dates into a new column. To prevent unintended changes to this column and to reduce file size, the column was converted to values, and the error codes were deleted.

The column "NewSite" describes whether each row represents the first row for a new site when the table is sorted by station number then by date. The column was developed in order to make the table simpler to filter and troubleshoot. This statement is dependent on the sort order of the table and requires that the table be sorted first by site_no and then by date in chronological order.

The column "Rating lookup code, $Q_{\text {same }}$ " contains the lookup code for the appropriate expanded shifted rating to compute $Q_{\text {same }}$. It was populated using an IF statement that checks the previous two columns. If the column "Expanded rating code" contains a non-blank value, the statement returns that value. If the column "NewSite" indicates the site is new, it returns the value "No rating available" until the first rating is available. Otherwise, the statement copies the previous value in this column. Like the statement in the column "NewSite," this statement is dependent on the sort order of the table and requires that the table be sorted first by site_no, then chronologically. The statement was written to allow the inclusion of values from the period before valid expanded shifted ratings were available because of the iterative fashion in which this dataset was developed and to accommodate the possibility that the initial retrieval was incomplete and additional valid shifts might be located.

The column "Stage" contains a derived value for stage. It is the stage value corresponding to the flow value closest to $Q_{\text {meas }}$ in the relevant expanded shifted rating. The column was populated through a reverse lookup from the rating tables using the INDEX, MATCH, and OFFSET commands. The value from "Rating lookup code, $Q_{\text {same }}$ " was used to find the appropriate column in the table of ratings; then the stage value matching the closest discharge value to $Q_{\text {meas }}$ from that column was returned. Although all possible values of stage appear in rating tables, not all possible values of flow appear. Daily mean flow is computed by averaging the unit values for flow observed on a particular day, so the value of $Q_{\text {meas }}$ may be a number that does not appear on a rating table. If flow values and ratings are added to those in the files, the addresses in the INDEX-MATCH-OFFSET statement must be modified to accommodate them.

This issue of rounding and of rating tables lacking many possible values for $Q_{\text {meas }}$ was the reason the column " $Q_{\text {same }}$ " 
was developed. The column " $Q_{\text {same }}$ " gives the flow value corresponding to the Stage value in the relevant rating table. This was done to remove one source of error when comparing the changes in rating tables in effect from the time of one flow measurement to the next. A direct comparison between $Q_{\text {meas }}$ and $Q_{\text {prev }}$ often included differences in flow for the same value of Stage, even if the rating was unchanged. The column was populated through a lookup from the rating tables using the INDEX and MATCH commands. The value from "Rating lookup code, $Q_{\text {same }}$ " was used to find the appropriate column in the table of ratings, then the flow value from that column on the row matching the value for Stage was returned. If flow values and ratings are added to those in the files, the addresses in the INDEX-MATCH-OFFSET statement must be modified to accommodate them.

The column "Rating lookup code, $Q_{\text {prev }}$ " contains the lookup code for the appropriate expanded shifted rating to compute $Q_{\text {prev }}$, the flow value that would have been obtained had the expanded shifted rating in effect at the time of the previous flow measurement remained in effect. It was populated using an IF statement that checks "Expanded rating code" and "Rating Lookup Code, $Q_{\text {same. }}$." If the column "Rating Lookup Code, $Q_{\text {same }}$ " contains the value "No rating available," the statement returns that value. For values in that column that are not equal to values in the previous cell in that same column, it returns the value from that previous cell. Otherwise, the statement copies the value in this previous cell of its own column. Like the statements in the columns "NewSite" and "Rating Lookup Code, $Q_{\text {same, }}$, this statement is dependent on the sort order of the table and requires that the table be sorted first by site_no, then chronologically.

The column "Difference $Q_{\text {same }}$ " gives the difference between $Q_{\text {meas }}$ and $Q_{\text {same }}$. It was obtained by subtracting $Q_{\text {same }}$ from $Q_{\text {meas }}$. This column was developed for troubleshooting.

The column " $Q_{\text {prev }}$ " gives the flow value that would have been obtained from the expanded shifted rating in effect at the time of the previous flow measurement, had it remained in effect. The column was populated through a lookup from the rating tables using the INDEX and MATCH commands. The value from "Rating lookup code, $Q_{\text {prev }}$ " was used to find the appropriate column in the table of ratings, then the flow value from that column on the row matching the value for Stage was returned. Valid values for $Q_{\text {prev }}$ became available once two flow measurements were made after the base ratings and shifts began to be stored in the database. For the period between the first and second flow measurements subsequent to shifts being stored in the database, values of $Q_{\text {same }}$ are available, but values of $Q_{\text {prev }}$ are not. If flow values and ratings are added to those in the files, the addresses in the INDEX-MATCH-OFFSET statement must be modified to accommodate them.

The column "Difference $Q_{\text {prev }}$ " gives the difference between $Q_{\text {meas }}$ and $Q_{\text {prev }}$. It was obtained by subtracting $Q_{\text {prev }}$ from $Q_{\text {meas }}$. This column was developed for troubleshooting.

The column "Check for hiatus" checks for a hiatus in record. It was populated using an IF statement that, within the records for a given streamgage, checks whether successive values in the "Date" column are more than one day in magnitude; when they are, the row in question is flagged as representing a hiatus in record. For such records, the ratings in effect before the hiatus were judged to be unrepresentative of variation typical from one normally scheduled site visit to the next, and values of $Q_{\text {prev }}$ were deleted for the period before two post-hiatus site visits had been made. One site, 01671025, North Anna River above Little River near Doswell, is a continuous station with a limited discharge computation range, and as a result, it had numerous breaks in record of one to several days that resulted in false positives for this IF statement. The column "Comments" contains comments, principally relating to a hiatus in record or other reason for values to have been deleted.

If a user of this spreadsheet wishes to update the AltFlow record as new data become available, that may be accomplished by using the following procedure.

1. Open the desired file and determine whether available computers will process the files in an acceptable manner. If not, consider editing historical ratings and daily values out of the files to speed processing times.

2. Retrieve the desired daily values from NWIS-Web and paste them to the bottom of the table that contains daily values from the same streamgages. Sort each table so that data are grouped first by site, and then chronologically.

3. Retrieve a table of flow measurements for the same period from NWIS-Web. Extract the station numbers and dates for each site visit.

4. Follow the procedure described above to obtain and format all the necessary expanded, shifted ratings. Append the additional ratings to the tables which contain ratings from the same streamgages.

5. Modify the INDEX-MATCH and INDEX-MATCH-OFFSET commands in the flow tables so that they include the entire updated range of values in the rating tables.

6. Copy the formulas in the flow tables to the blank cells in the rows that have been added. Compute the AltFlows.

7. If desired, copy the AltFlows as values to a separate, smaller file for further analysis.

\section{References Cited}

Messinger, Terence, and Burgholzer, R.W., 2017, Ratings and estimated provisional streamflow for streamgages in Virginia, water years 1991 through 2013: U.S. Geological Survey data release, https://doi.org/10.5066/F72R3PXB. 


\section{Appendix 3. UNIX shell scripts used to develop AltFlow record}

This software has been approved for release by the U.S. Geological Survey (USGS). Although the software has been subjected to rigorous review, the USGS reserves the right to update the software as needed pursuant to further analysis and review. No warranty, expressed or implied, is made by the USGS or the U.S. Government as to the functionality of the software and related material nor shall the fact of release constitute any such warranty. Furthermore, the software is released on condition that neither the USGS nor the U.S. Government shall be held liable for any damages resulting from its authorized or unauthorized use.

Appendix 3 is a spreadsheet with multiple tabs/worksheets, which contain short UNIX scripts, or Excel formulas that may be used to produce one-line UNIX scripts, to perform some of the data manipulation involved in converting expanded, shifted ratings retrieved from the National Water Information System as separate files to a joined table of the type in appendix 2, with gage height in the left column and one column for each expanded, shifted rating. They have been tested in the ksh shell under Solaris Unix version SunOS 5.10. Although these scripts may work on computers running other shells or under other UNIX and UNIX-like operating systems, they have not been tested in other environments.

Appendix 3 is available online at https://doi.org/10.3133/sir20175137 


\section{Appendix 4. Plots showing daily time series of $\boldsymbol{Q}_{\text {same }}$ and $\boldsymbol{Q}_{\text {prev }}$}

\section{A. For the North Atlantic Slope Basins}

Plots showing daily time series of $Q_{\text {same }}$ (the flow value from the shifted rating table used to compute the daily flow value at the time of the most recent flow measurement that corresponds to the gage height of each day's daily flow value) and $Q_{\text {prev }}$ (the flow value from the shifted rating table in effect at the time of the previous flow measurement that corresponds to the gage height of each day's daily flow value) and dates when flow measurements were made for all real-time streamgages in Virginia active on September 30, 2013, with 20 or more flow measurements with positive flow values, for the North Atlantic Slope Basins. Flows are shown as $\log _{10}$ of the actual flows, and negative values reflect daily flows that were less than 1 cubic foot per second. Erratic and abrupt changes in $Q_{\text {prev }}$ result from relatively large, sudden changes in ratings.

\section{B. For the South Atlantic Slope Basins}

Plots showing daily time series of $Q_{\text {same }}$ (the flow value from the shifted rating table used to compute the daily flow value at the time of the most recent flow measurement that corresponds to the gage height of each day's daily flow value) and $Q_{\text {prev }}$ (the flow value from the shifted rating table in effect at the time of the previous flow measurement that corresponds to the gage height of each day's daily flow value) and dates when flow measurements were made for all real-time streamgages in Virginia active on September 30, 2013, with 20 or more flow measurements with positive flow values, for the South Atlantic Slope Basins. Flows are shown as $\log _{10}$ of the actual flows, and negative values reflect daily flows that were less than 1 cubic foot per second. Erratic and abrupt changes in $Q_{\text {prev }}$ result from relatively large, sudden changes in ratings.

\section{For the Ohio River Basin}

Plots showing daily time series of $Q_{\text {same }}$ (the flow value from the shifted rating table used to compute the daily flow value at the time of the most recent flow measurement that corresponds to the gage height of each day's daily flow value) and $Q_{\text {prev }}$ (the flow value from the shifted rating table in effect at the time of the previous flow measurement that corresponds to the gage height of each day's daily flow value) and dates when flow measurements were made for all real-time streamgages in Virginia active on September 30, 2013, with 20 or more flow measurements with positive flow values, for the Ohio River Basin. Flows are shown as $\log _{10}$ of the streamflow in cubic feet per second, and negative values result from daily flows that were less than 1 cubic foot per second. Erratic and abrupt changes in $Q_{\text {prev }}$ reflect relatively large, sudden changes in ratings. 

For more information concerning the research in this report, contact: Director, Virginia Water Science Center

U.S. Geological Survey

1730 East Parham Road

Richmond, Virginia 23228

http://va.water.usgs.gov/

Publishing support provided by the

West Trenton Publishing Service Center 
